
AmS-Varia

Mari Høgestøl

Lisbeth Prøsch-Danielsen

$\&$ Olav Walderhaug

\title{
Bergkunst på Midt- og Sør-Jæren samt i Dalaneregionen, Rogaland Motiver, historikk, naturmiljø og tilstand
}

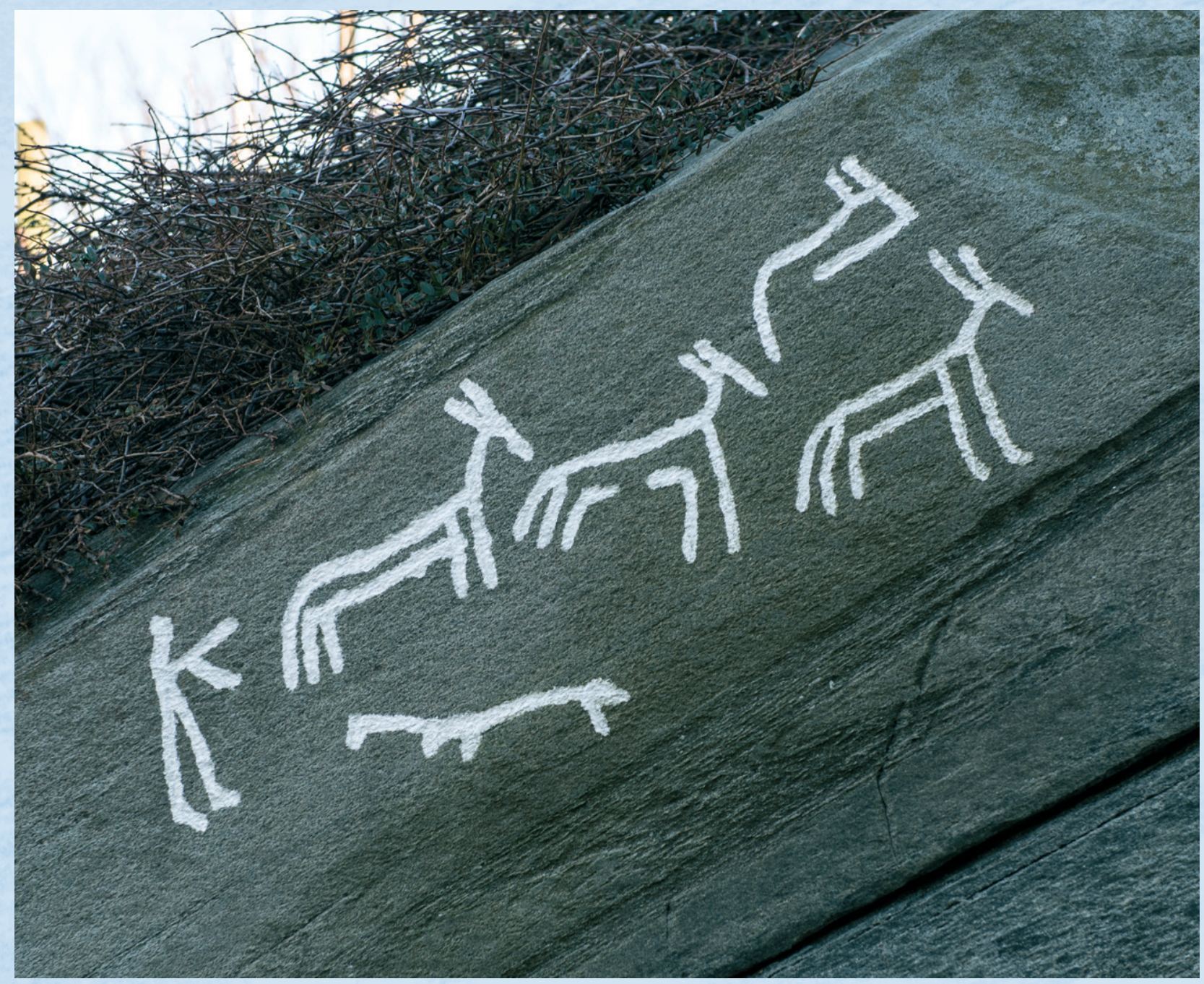

ARKEOLOGISK
MUSEUM 
AmS-Varia 59

Arkeologisk museum, Universitetet i Stavanger

Museum of Archaeology, University of Stavanger

\section{Bergkunst på Midt- og Sør-Jæren samt i Dalaneregionen, Rogaland Motiver, historikk, naturmiljø og tilstand}

Mari Høgestøl, Lisbeth Prøsch-Danielsen \& Olav Walderhaug 


\section{AmS-Varia 59}

Arkeologisk museum, Universitetet i Stavanger

Museum of Archaeology, University of Stavanger

Redaksjon/Editorial office:

Arkeologisk museum, Universitetet i Stavanger

Museum of Archaeology, University of Stavanger

Redaktør av serien/Editor of the series: Kristin Armstrong Oma

Redaktør av dette volumet/Editor of this volume: Wenche Brun

Formgiving/Layout: Ingund Svendsen

Redaksjonsutvalg/Editorial board:

Kristin Armstrong Oma (leder/chief editor)

Wenche Brun

Lisbeth Prøsch-Danielsen

Ingund Svendsen

Linn Lillian Eikje Ramberg

Utgiver/Publisher:

Arkeologisk museum, Universitetet i Stavanger

Museum of Archaeology, University of Stavanger

N-4036 Stavanger, Norway

Tel.: (+47) 51832600

E-mail: post-am@uis.no

arkeologisk.museum.no

ISSN 0332-6306

ISBN 978-82-7760-180-9

Opplag/Printed editions: 350

Stavanger 2018

(C) Arkeologisk museum, Universitetet i Stavanger. Alt innhold er opphavsrettslig beskyttet. Gjengivelse eller formidling av hele eller deler av denne boken, elektronisk, mekanisk eller annen metode kjent eller senere utviklet, er ikke tillatt uten skriftlig tillatelse fra forlaget. Dette inkluderer fotokopi, opptak, lydopptak, eller i lagrings- og gjenfinningssystemer.

(c) Museum of Archaeology, University of Stavanger. All rights reserved. No part of this book may be reprinted or reproduced or utilised in any form or by any electronic, mechanical, or other means, now known or hereafter invented, including photocopying and recording, or in any information storage or retrieval system, without permission in writing from the publisher.

Forsidefoto/Cover photo: Åge Pedersen, AM, UiS.

Omslagsdesign/Cover design: Ingund Svendsen, AM, UiS. 


\section{Abstract}

Høgestøl. M., Prøsch-Danielsen, L. \& Walderhaug, O. 2018: Bergkunst på Midt- og Sør-Jæren samt i Dalaneregionen, Rogaland. Motiver, historikk, naturmiljø og tilstand. Rock art in the central and southern part of Jæren and in the region of Dalane, Rogaland. Motives, history, environmental setting and present condition. AmS-Varia 59. 84 pp. Stavanger. ISSN 0332-6306, ISBN 978-82-7760-180-9.

In Rogaland County, southwestern Norway, one of the country's largest collections of rock art can be found: ca. 110 sites with figures and cup marks, 38 grave monuments with decorated slabs or stones with cup marks (altogether 67 slabs) and 37 stray finds of decorated slabs or stones with cup marks. In 1996, the Museum of Archaeology, University of Stavanger established an interdisciplinary group working primarily on the documentation and preservation of rock art. This group was part of the National Rock Art Project, a program run by the Norwegian Directorate for Cultural Heritage. The project lasted until 2005, after which the Directorate granted supplemental funds for continuing the work. Two previous papers have been published concerning rock art in Rogaland (AmS-Rapport 9 and AmS-Rapport 19).

In this publication, we will present 15 sites with figures and cup marks, 20 with cup marks only and 61 decorated slabs and stones with cup marks recovered from either grave monuments or as stray finds. Ships are the most common motive, but the range of motives also includes simple discs, wheel crosses and, more rarely, human figures, horses and axes. As far as possible, these sites are put into an environmental context in terms of vegetation history, sea-level fluctuations and geological conditions. Furthermore, the publication contains an historical outline of earlier investigations and documentation as well as descriptions and the present status from the rock art sites. Damage and weathering are also described. Finally, we present interpretations of the symbolism and cultural background of the rock art.

Key words: Rock art, southwestern Norway, Jæren, Dalane, environmental factors, weathering, bedrock

Mari Høgestøl, Museum of Archaeology, University of Stavanger, N-4036 STAVANGER, NORWAY. E-mail: mari.hogestol@uis.no

Lisbeth Prøsch-Danielsen, Museum of Archaeology, University of Stavanger, N-4036 STAVANGER, NORWAY. E-mail: lisbeth.prosch-danielsen@uis.no

Olav Walderhaug, Equinor ASA, Svanholmen 8, N-4035 STAVANGER, NORWAY.

E-mail: owald@equinor.com 


\section{Innhold}

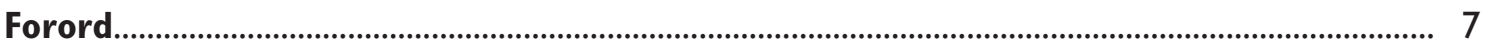

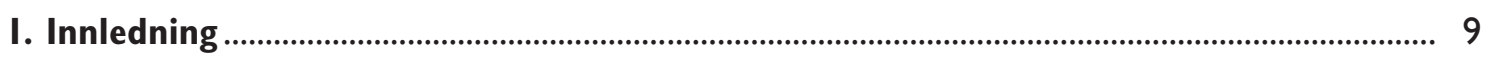

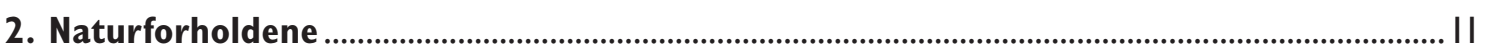

2.I Geografi og topografi....................................................................................................... I

2.2 Berggrunn .................................................................................................................... II

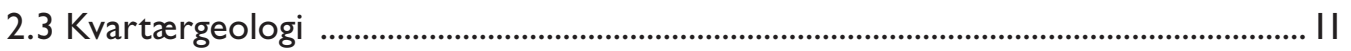

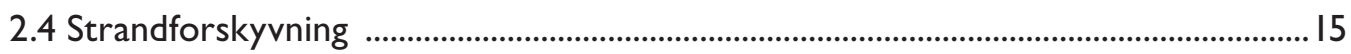

2.5 Vegetasjonsutviklingen de siste 6000 årene - jordbrukslandskapet oppstår.......... 17

3. Sola kommune

3.I Bergkunstlokaliteter ............................................................................................. 19

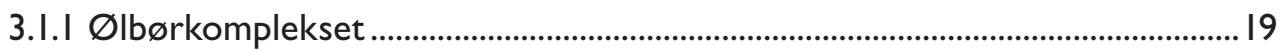

3.I.2 Vigdel-Hellestøkomplekset....................................................................................26

3.I.3 Kråkhaug - Valhaugkomplekset........................................................................... 34

3.2 Landskap i endring ............................................................................................................ 44

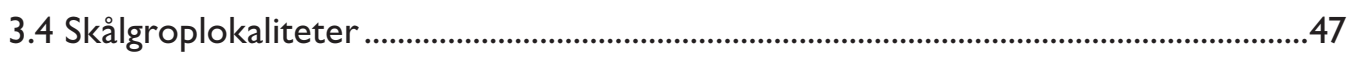

3.5 Løse heller og blokker med ristninger og skålgroper .................................................... 48

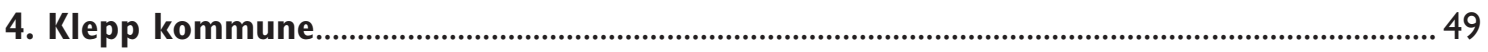

4.I Bergkunst- og skålgroplokaliteter ...................................................................................49

4.2 Løse heller og blokker med ristninger og skålgroper ....................................................5I

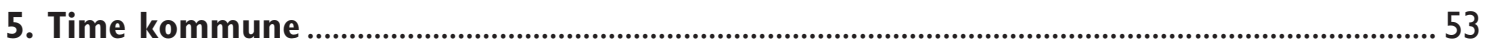

5.I Løse heller og blokker med ristninger og skålgroper ......................................................53

6. Hå kommune.

6.I Løse heller og blokker med ristninger og skålgroper ................................................... 54

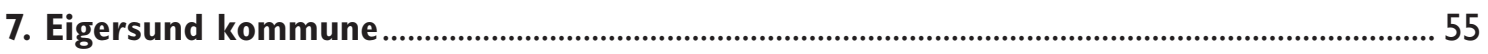

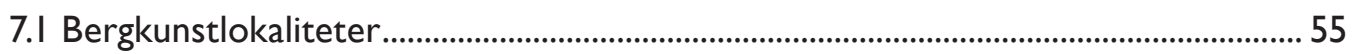

7.2 Skålgroplokaliteter ..................................................................................................... 57

7.3 Løse heller og blokker med ristninger og skålgroper..................................................... 58

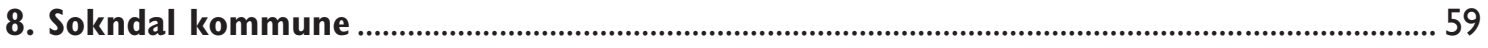

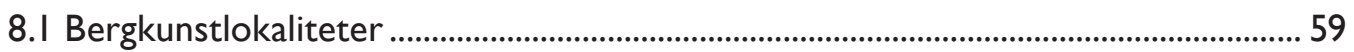

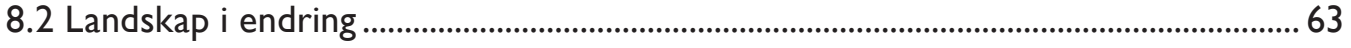

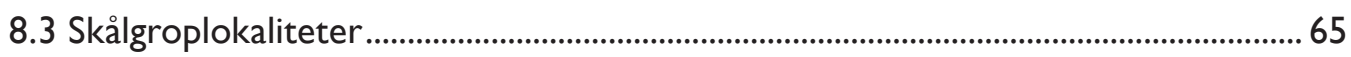




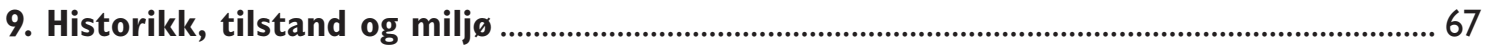

9.I Når ble ristningene funnet og registrert? ....................................................................... 67

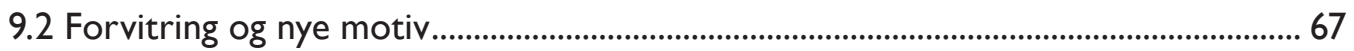

9.3 Endring over tid og menneskeskapte skader ...................................................................... 68

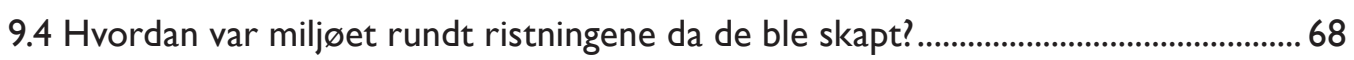

10. Bergkunstfeltene - motiv, datering og tolkning .................................................................

10.I Motivene på de åpne bergkunstlokalitetene..............................................................

I0.2 Datering og tolkning........................................................................................................

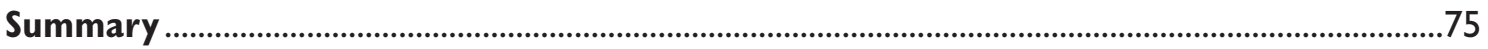

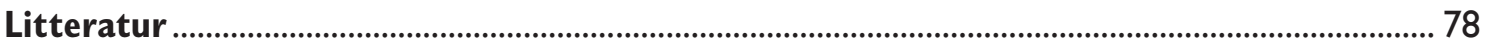




\section{Forord}

Arkeologisk museum, Universitetet i Stavanger har tidligere gitt ut to publikasjoner vedrørende bergkunst i Rogaland: «Helleristningsfeltene på Austre Åmøy, Stavanger kommune, Rogaland. Dokumentasjon, sikring og tilrettelegging av feltene I til VI-5» (Høgestøl et al., 1999) og «Helleristningslokaliteter i stavangerområdet, Rogaland. Dokumentasjon, sikring og tilrettelegging» (Høgestøl et al., 2006). Begge arbeidene ble skrevet som et resultat av Riksantikvarens nasjonale bergkunstprosjekt som pågikk i perioden 1996 til 2005, og var et fellesskriv fra deltakerne i det tverrfaglige prosjektet i Rogaland. Arbeidene omhandlet lokalitetshistorikk og presentasjon av figurer, men også naturforhold, vegetasjon og vegetasjonsutvikling, bergart, geologisk vitring og slitasje inklusive endringer over tid samt eventuelle skader på bergkunsten påført av mennesker. Dette arbeidet som omhandler bergkunst $\mathrm{i}$ Midt- og Sør-Jæren samt Dalaneregionen er skrevet over samme lest, men er utvidet noe ved at skålgroplokaliteter samt ristnings- og gropsteiner som stammer fra graver eller fra løsfunn er tatt med. Dermed får presentasjonen en større bredde som i sin tur kan gi rom for å se de ulike bergkunsttypene i forhold til hverandre.

I forbindelse med Riksantikvarens bergkunstprosjekt ble alle åpne lokaliteter med figurer og et flertall av skålgroplokalitetene nydokumentert av arkeolog Gitte Kjeldsen og opplysningene lagt inn i den daværende bergkunstdatabasen. Dokumentasjonen er seinere delvis overført til Riksantikvarens kulturminnedatabase Askeladden. Samtidig ble det foretatt fotodokumentasjon av Åge Pedersen. Under og etter at prosjektet ble avsluttet, er det foretatt så å si årlig skjøtsel og oppfølging av alle lokaliteter med figurer, mens flertallet av skålgroplokalitetene i hovedsak kun er kontrollert hvert 4. eller 5. år. Noen få er imidlertid tettere fulgt opp, og av den grunn omtales disse i dette arbeidet på samme måte som bergkunstlokaliteter med figurer, mens flertallet kun får en kort omtale.

Mari Høgestøl er ansvarlig for innledning, beskrivelser av lokalitetene, avsnittene vedrørende endringer over tid samt oppsummeringskapitlene. Lisbeth Prøsch-Danielsen har beskrevet naturforhold, strandlinjer og landskap, og Olav Walderhaug har beskrevet bergarten og geologisk vitring og slitasje på den enkelte lokalitet. Bitten Bakke har foretatt skadekartleggingen som er avmerket på en del av kalkeringene. Øvrig arbeid er gjort i fellesskap av de to førstnevnte forfatterne.

En stor takk rettes til Gitte Kjeldsen som har gitt gode innspill vedrørende dateringer, Krister Eilertsen, Åge Pedersen, Ingund Svendsen og Terje Tveit for hjelp med figurer og bilder samt Einar Solheim Pedersen og Sean Denham for gjennomlesing og språkvask, henholdsvis på norsk og engelsk.

Stavanger, november 2018

Mari Høgestøl, Lisbeth Prøsch-Danielsen \& Olav Walderhaug 


\section{Innledning}

Rogaland er ett av områdene i Norge med størst konsentrasjon av åpne bergkunstlokaliteter og heller og steiner med ristninger og/eller groper. Det er til nå påvist 186 lokaliteter. Fra den første lokaliteten ble registrert i 1866 har tilveksten vært jevn fram til i dag, med unntak særlig av to perioder da det ble påvist mange nye lokaliteter; først i forbindelse med Tor Helliesens registreringer rundt forrige århundreskiftet, dvs. i perioden 1900 til 1909 og deretter ved Eva og Per Fetts registreringer og kartlegginger på 1930-tallet. En tredje, men langt svakere oppgang kom på midten av 1960-tallet i forbindelse med førstegangsregistreringer for Økonomisk kartverk (Bakke et al., 2000). I de seinere år er det i 2011, 2014 og 2016 påvist ytterligere tre lokaliteter, henholdsvis på Bru i Rennesøy kommune, Saltveit i Haugesund kommune (Høgestøl, 2017) og på Vestre Åmøy i Rennesøy kommune (muntlig opplysning, Gitte Kjeldsen).

Med unntak av én bergmalingslokalitet består de øvrige av ristninger med a) kun figurer (35), b) figurer og skålgroper (25), c) rene skålgroplokaliteter i fast fjell eller i faste og løse blokker (50) samt d) heller og blokker med figurer og skålgroper funnet i graver, såkalte gravristninger. Sistnevnte utgjør 38 lokaliteter (med til sammen 67 heller eller steiner med ristninger) samt 37 løse steiner med bergkunst, der mange opprinnelig kan ha stammet fra graver (Syvertsen, 2002). I tillegg er det i kulturminnebasen Askeladden registrert sju usikre skålgroplokaliteter, en mulig bergmaling samt en lokalitet med figurer som høyst sannsynlig er hogd i moderne tid. Enkelte av de tidligere registrerte skålgroplokalitetene som ligger nær sjøen og med en diameter på opptil $20 \mathrm{~cm}$, er seinere vurdert til å være små jettegryter.

Dette arbeidet omhandler 15 lokaliteter fra Midt- og Sør-Jæren samt Dalaneregionen der det på enkelte også er registrert skålgroper, 20 rene skålgroplokaliteter og 43 lokaliteter med i alt 61 løse steiner med figurer eller skålgroper som stammer eller kan stamme fra graver.

Storparten av bergkunsten i landskapet ligger på Nord-Jæren og særlig da i Stavanger kommune, der de største og mest figurrike lokalitetene finnes, med hele 80 $\%$ av figurtilfanget. Lokalitetene som skal behandles og omtales her, har færre figurer enn på Nord-Jæren, men har en mer variert figursammensetting og uttrykk. De vanligste motivene på bergkunsten i Rogaland er skip og skålgroper, men det finnes også solhjul, ringer, spiraler, ramme- og gitterfigurer, fotsåler m.m. Eksplisitte menneske- og dyrefigurer er mer sjeldne, men mange av de som er påvist i Rogaland finnes på lokalitetene i Sola kommune. Videre, i Dalaneregionen er en del av figurene spesielle, sammenlignet med det øvrige rogalandsmaterialet; et skip har f.eks. øks i stavnen, mens andre har en form som minner mer om bergkunsten i Østfold/Bohuslän enn den i Rogaland og på Vestlandet for øvrig.

Publikasjonen har tre hovedmål:

1. A gi en presentasjon av lokalitetenes historie; når de ble funnet og registrert, hvilke figurtyper som finnes på den enkelte lokalitet samt deres tidsmessige plassering. Det er samlet inn opplysninger fra arkiv, publikasjoner og rapporter. I forbindelse med skjøtselsarbeid og dokumentasjon er det også påvist nye figurer på en del av lokalitetene samt foretatt omtolkinger av andre. Gravristninger og løse heller med figurer og groper er også inkludert i arbeidet. Avslutningsvis vil de derfor bli sammenlignet med de åpne ristningene, og det hele forsøkt satt inn i en kulturhistorisk sammenheng.

2. A gi en beskrivelse og analyse av hvordan miljøet var rundt ristningene da de ble skapt. Geologiske forhold, vegetasjonshistorie og lokalisering er sentrale faktorer i forståelsen av ristningstradisjonen. Hvilke faktorer som styrte utvelgelsen av steder for hogging av bergkunst, og eventuelle sammenhenger mellom lokalisering og tilgang til dyrka mark, samt strandlinjestudier, vil bli belyst i publikasjonen. Videre er det i forbindelse med skjøtselsarbeidet viktig å få kunnskap om hvordan miljøet rundt ristingene var da de ble skapt, og hvordan utviklingen har vært fram til i dag. Dette for å kunne forsøke å gjenskape det miljøet som har ført til at bergkunsten er blitt bevart gjennom tusener av år og for å kunne sette inn de rette avbøtende tiltakene.

3. Å gi en beskrivelse av bergarten, graden av forvitring, endringover tidsamtmenneskeskapteskader. Bergkunst er en sårbar kulturminnetype, og som for gjenstander ved museene kreves særlig oppfølging sammenlignet med andre kulturminnetyper. Det er derfor samlet inn opplysninger fra arkiv, publikasjoner, rapporter, og en 
har studert eldre fotografier for å undersøke om det har vært endringer mht. forvitring av bergkunsten fram til i dag. Noen av beskrivelsene har imidlertid preg av å være basert på subjektive inntrykk. For å kunne bevare bergkunsten for framtida og for å kunne sette inn avbøtende tiltak, har vi derfor i arbeidet vårt lagt vekt på å gi en status for 2000-tallet. Konservator har undersøkt lokalitetene for «bommer» og avskallinger, mens geolog har gitt en beskrivelse av bergart, graden av forvitring samt studert tynnslip av steinprøver hentet ut nær lokalitetene. På den måten håper vi å gi et godt grunnlag for framtidige undersøkelser av tilstand og forvitringsgrad.

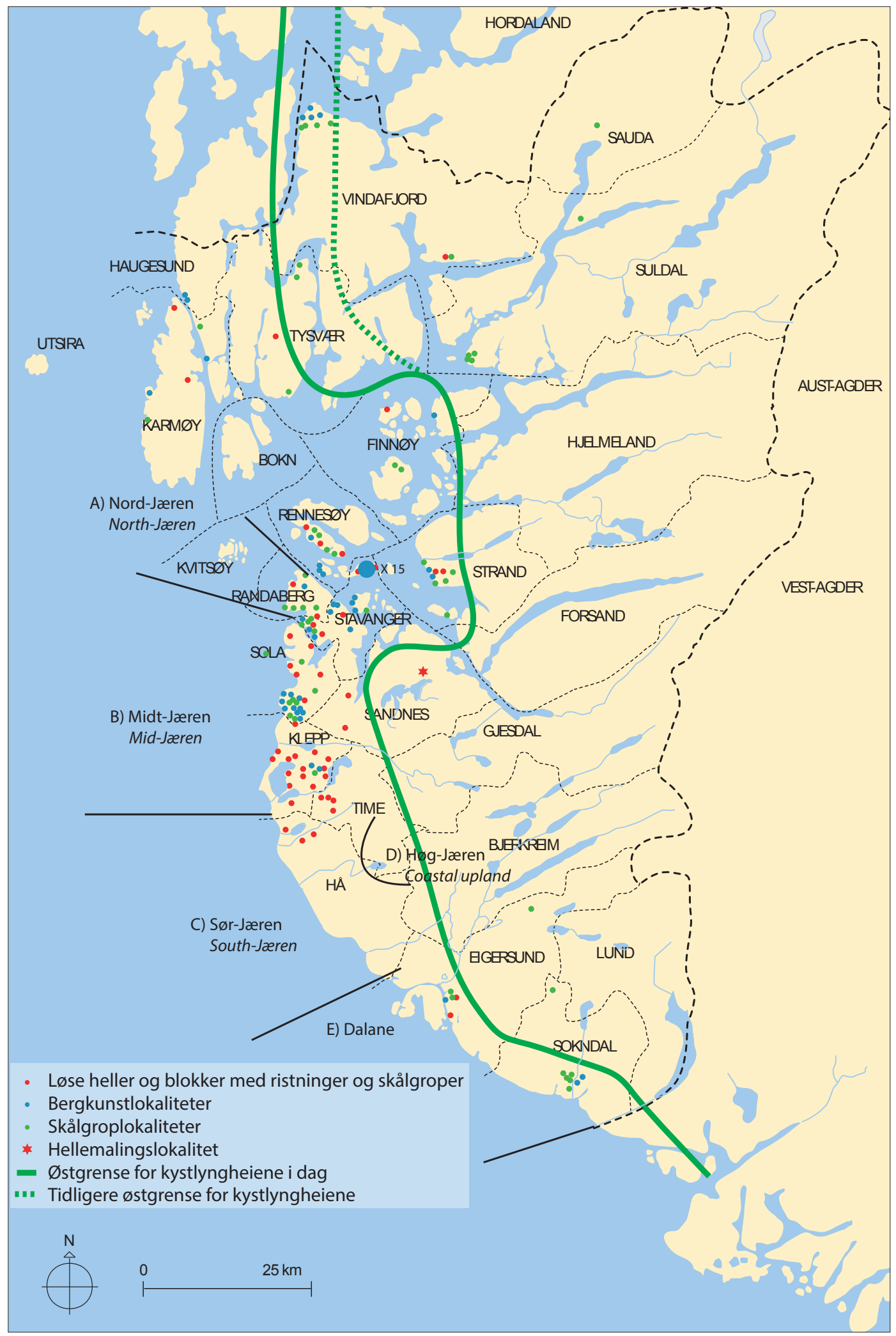

Fig. I. Kartet viser hvor de ulike bergkunstgruppene finnes i Rogaland (modifisert etter Bang-Andersen, 1999). Røde prikker kan representere flere heller/blokker. Den grønne streken markerer østgrensen for utbredelsen av kystlyngheiene (fra Prøsch-Danielsen, 2002).

Fig. I. Map of the distribution of rock art sites (blue dots), rock painting (red star), cup mark sites (green dots) and sites with ornamented grave slabs (red dots) (modified after BangAndersen, 1999). Each red dot may represent several slabs. The eastern border of the coastal heath section is marked with a green solid line (after ProschDanielsen, 2002). 


\section{Naturforholdene}

\section{I Geografi og topografi}

I AmS-Rapport 19 (Høgestøl et al., 2006) beskrev vi bergkunstlokalitetene som ligger på stavangerhalvøya på Nord-Jæren (A) og som utgjør den nordligste delen av Låg-Jærens slettelandskap. I dette arbeidet beveger vi oss videre sørover i dette slettelandskapet. Jæren deles topografisk i vest-øst-retning i en lavtliggende ytre kystbrem som kalles Låg-Jæren (A-C) (opp til 70 moh.) og i et indre oppland som kalles Høg-Jæren (D) (opp til 250 moh.), der disse er skilt av en markant skråning. Sola, Klepp, Sandnes og Time kommuner utgjør Midt-Jæren (B), mens Hå kommune lengst i sør utgjør Sør-Jæren (C) (Fig. 1, Fig. 2a). Hovedtyngden av jordbruksristningene finnes på bergknauser i Sola kommune, mens det per i dag bare er kjent tre lokaliteter i Klepp kommune og ingen i Time og Hå kommuner. At ristningstradisjonen også fantes på LågJæren for øvrig kan vi se av de mange skålgropene og ornamenterte gravhellene som finnes på løsblokker og heller der, men lokalitetene avtar både østover og sørover (Fig. 1).

Bergkunstlokalitetene i Eigersund og Sokndal kommuner ligger lengst sør i Rogaland fylke, nærmere bestemt i Dalane-regionen (E), der regionen er skilt ut på grunnlag av berggrunnsgeologiske forhold.

\subsection{Berggrunn}

Berggrunnen på Midt- og Sør-Jæren kan i likhet med berggrunnen på stavangerhalvøya deles inn i tre hovedtyper; det prekambriske grunnfjellet, de kambro-ordovisiske sedimentære bergartene og det kaledonske skyvedekket (Fig. 2a) (Birkeland, 1981; Wishaupt \& van Wees, 1985; Maijer et al., 1987; Norges geologiske undersøkelse, 2009). I dette området er imidlertid berggrunnen hovedsakelig dekket av kvartærgeologiske avsetninger med en mektighet på minst 50 m (Fig. 2b) (Andersen et al., 1987; Jorde et al., 1995; Sejrup et al., 1998, 1999; Stalsberg et al., 1999).

De eldste bergartene er de prekambriske grunnfjellsgranittene og gneisene som ses øst for en forkastningssone der Njå-Lyefjellet og Høg-Jæren reiser seg opp fra Låg-Jærens løsmasser. Over dette grunnfjellet ligger det et lag med fyllitt. Mens bergkunsten på stavangerhalvøya er hogd i denne fyllitten (Prøsch-Danielsen, 2002, Fig. 3; Høgestøl et al., 2006, Fig. 2), er ikke dette mønsteret på Midt- og Sør-Jæren. Her eksponeres bare fyllitten i enkelte partier langs den nevnte forkastningssonen i øst, og ristninger mangler helt i dette området.

Over fyllitten finner vi de kaledonske skyvedekkebergartene (Jæren-formasjonen) også med antatt prekambrisk alder. De består hovedsakelig av ulike typer skifre, gneiser og granitter slik som grunnfellsbergartene. Skyvedekkebergartene er som nevnt stort sett dekket av løsmasser og er i liten grad eksponerte. På LågJæren kommer bare berggrunnen opp i dagen i enkelte partier fra tanangerhalvøya i Sola til Nærbø i Hå kommune. Dette kan være hovedgrunnen til at det er mangel på ristninger sørover på Jæren og i midtre sentrale områder. Der bergkunsten forekommer på Midt-Jæren, består berggrunnen av varierende typer glimmergneiser. For nærmere detaljstudier, se under beskrivelse av hver enkel bergkunstlokalitet.

Bergartene i Dalane-regionen hører til grunnfjellsbergartene, men her er de en del av Rogalands anortosittprovins som omfatter flere anortositt-massiver (Marker et al., 2003). Ristningene i Eigersund ligger innenfor det eldste massivet, som finnes i vest, kalt Eigersund-Ognaanortositten. Figurene her finnes i et belte av leukonoritt som gir bergarten en mørk farge. Ristningene i Sokndal ligger innenfor den yngre Bjerkreim-Sokndal-intrusjonen i et belte med norittiske mørke bergarter. For nærmere detaljstudier, se under beskrivelse av hver lokalitet. Yngre bergarter forekommer ikke i Dalane-regionen.

\subsection{Kvartærgeologi}

Under siste istid ble Midt-Jæren fri for innlandsisen om lag 14000 år f.Kr. (Knudsen, 2006; Knudsen et al., 2006), Sør-Jæren og Dalane-regionen trolig litt tidligere. De kvartærgeologiske avsetningene i Jæren-området består hovedsakelig av storblokkig morene og glasifluviale avsetninger eksponert i en mosaikk, samt marine og eoliske (vindblåste) sedimenter langs ytterkysten. Kvartærgeologisk deles Låg-Jæren inn i tre morfologiske enheter i nord-sør-retning (Fig. 2b) der stavangerhalvøya utgjør den nordligste enheten.

Midt-Jæren (B) strekker seg fra Hafrsfjord og sørover til Nærbø. Denne enheten er karakterisert av et haugete morenelandskap med grunne vann og løsmasserygger som ligger i øst-vest-retning (Sejrup et al., 1998). Dette 
landskapet brytes av kolossale grus- og sandrygger i et belte fra Frøylandsvatnet til Viktangen i vest, kalt Timeeskeren. Under siste istid hadde smeltevannet under isbreen hovedløp over Jæren nettopp her, og i siste fase av nedsmeltningen ble store løsmassemengder liggende

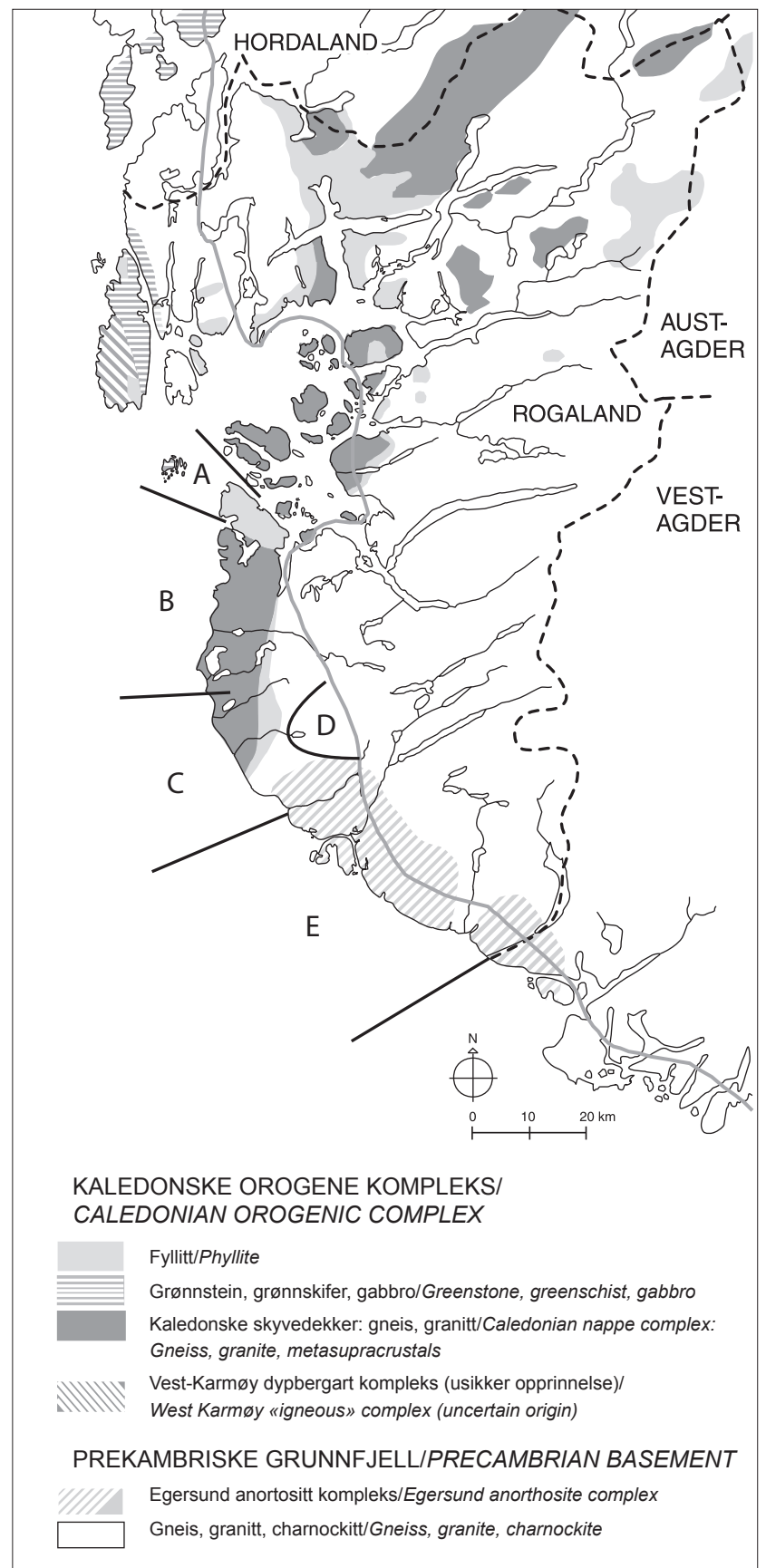

Fig. 2a. Forenklet berggrunnskart over Rogaland. På MidtJæren finnes kaledonske skyvedekkebergarter av antatt prekambrisk alder ovenpå en såle av fyllitt. Dalane-regionen tilhører Rogalands anortosittprovins (fra Prøsch-Danielsen \& Simonsen, 2000a).

Fig. 2a. A simplified bedrock map of Rogaland. In Mid-Jæren, the Caledonian nappe complex is exposed as gneiss, granite and metasupracrustals resting on a layer of phyllite that is exposed along the rim of the Jæren escarpment. In the Dalane region, the dominating rock is anorthosite (after Prøsch-Danielsen \& Simonsen, 2000a). igjen. Området innehar mange formasjoner fra istiden og fra den tidlige avsmeltningen. Disse løsmassene er lett drenerte og har gitt opphav til god og fruktbar jordbruksjord der bruken kan føres tilbake til mellom-neolitikum. Flere løsblokker med skålgroper og gravhauger med ornamenterte heller finnes på disse løsmasserike høydedragene i landskapet. Disse finnes bl.a. i terrenget nord, øst og sør for Orrevatn (Fig. 1). Løsmasser fra istiden har skapt et unikt landskap som stadig har vært i forandring, særlig langs ytterkysten. Dette vil vi komme tilbake til under omtalen av bergkunstkomplekset rundt Harvalandsvatnet.

Den sørligste kvartærgeologiske enheten $(C)$ finnes i området sør for Nærbø i Hå kommune (Sør-Jæren). Her mangler åpne bergkunstlokaliteter helt, men det rituelle

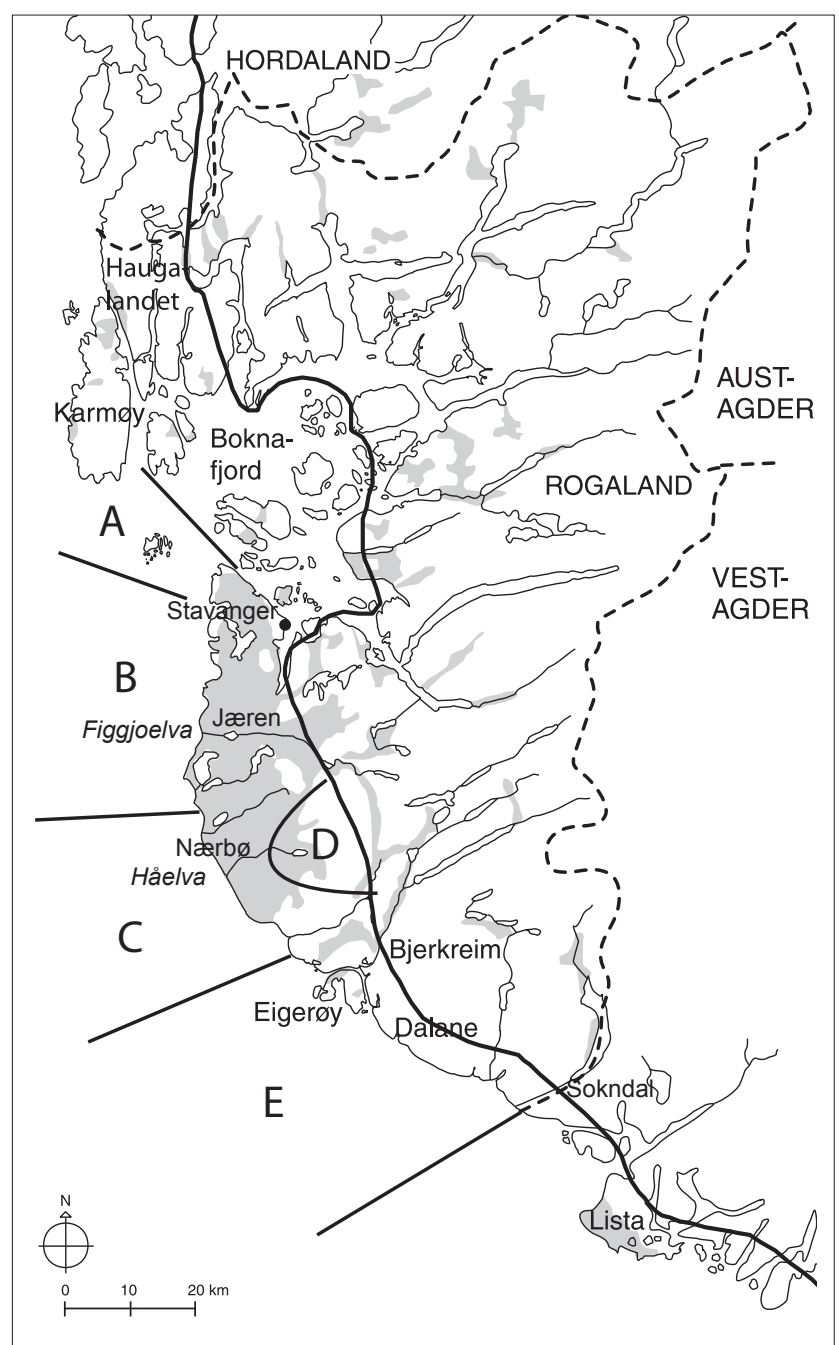

Fig. 2b. Kartet viser løsmasserike områder i Rogaland. Jæren er igjen delt inn i fire ulike landskapstyper; A) Nord-Jæren, B) Midt-Jæren og C) Sør-Jæren samt D) Høg-Jæren (fra PrøschDanielsen, 2002).

Fig. 2b. Map showing the distribution of Quaternary deposits in the county of Rogaland. Jæren is divided into four landscape regions. The low-lying part includes A) North-Jæren, B) Central-Jæren and C) South-Jæren. In addition, the upper coastal region $D$ ) is situated in the eastern part (the division follows Prøsch-Danielsen, 2002). 
Fig. 3. Utbredelsen av gravhauger og bergkunstfelt fra bronsealder på Jæren. Merk at dette området $\mathrm{i}$ vest allerede $\mathrm{i}$ SN/EBA var skogløst og besto av gressog lyngheier (rød linje). Avskogingen fortsatte så inn i YBA og JA videre mot øst til dagens lyngheigrense (hvit strek) (etter Prøsch-Danielsen et al., 2018).

Fig. 3. Distribution of burial monuments and rock art sites in Jæren. Note the clear association with the open heath-and grassland zone already created in LN/EBA in west (red line). Later on forest clearance proceeded eastward during LBA and IA to the present heathland border (white line) (after Prøsch-Danielsen et al., 2018).

landskapet er likevel synlig i form av gravhauger, gjerne konsentrert på begge sider av elvemunninger (B. Myhre 2013, s. 225; Prøsch-Danielsen et al., 2018) (Fig. 3). Her er landskapet strømlinjeformet med nordvest-sørøst-gående rygger som løper parallelt med kysten. Ryggene er drumliner (sigarformete morenerygger) avsatt av en isstrøm fra Norskerenna som førte med seg marine leirer. Her er også et yngre morenedekke. Sedimentene er blottlagte i en mosaikk, men det store innholdet av marine leirer har ført til dårlig drenering også på høydedragene.

På et jordbunnskart fra 1910 (Grimnes, 1910) kommer det tydelig fram at den dårlige dreneringen i sør har ført til at myrene har fått bre seg utover i terrenget. Kanskje var dette landskapet mindre attraktivt for åkerbruk i bronsealderen enn det lettere drenerte området på Midt-Jæren (Prøsch-Danielsen, 2002, 2013). De løse hellene/gropsteinene, funnet i Hå kommune, ligger alle nær grensen til det morfologiske skillet mellom Midtog Sør-Jæren (se Fig. 1).

Innen anortosittprovinsen er det de særpregete dypbergartene anortositt og noritt som gir landskapet et knauset og goldt preg. Disse er sure bergarter som ikke gir opphav til et fruktbart jordsmonn. Det er sparsomt med kvartærgeologiske avsetninger i dette området, selv om slike kan ses i dalganger i området (Wangen et al., 1987; Bergstrøm et al., 2010). De

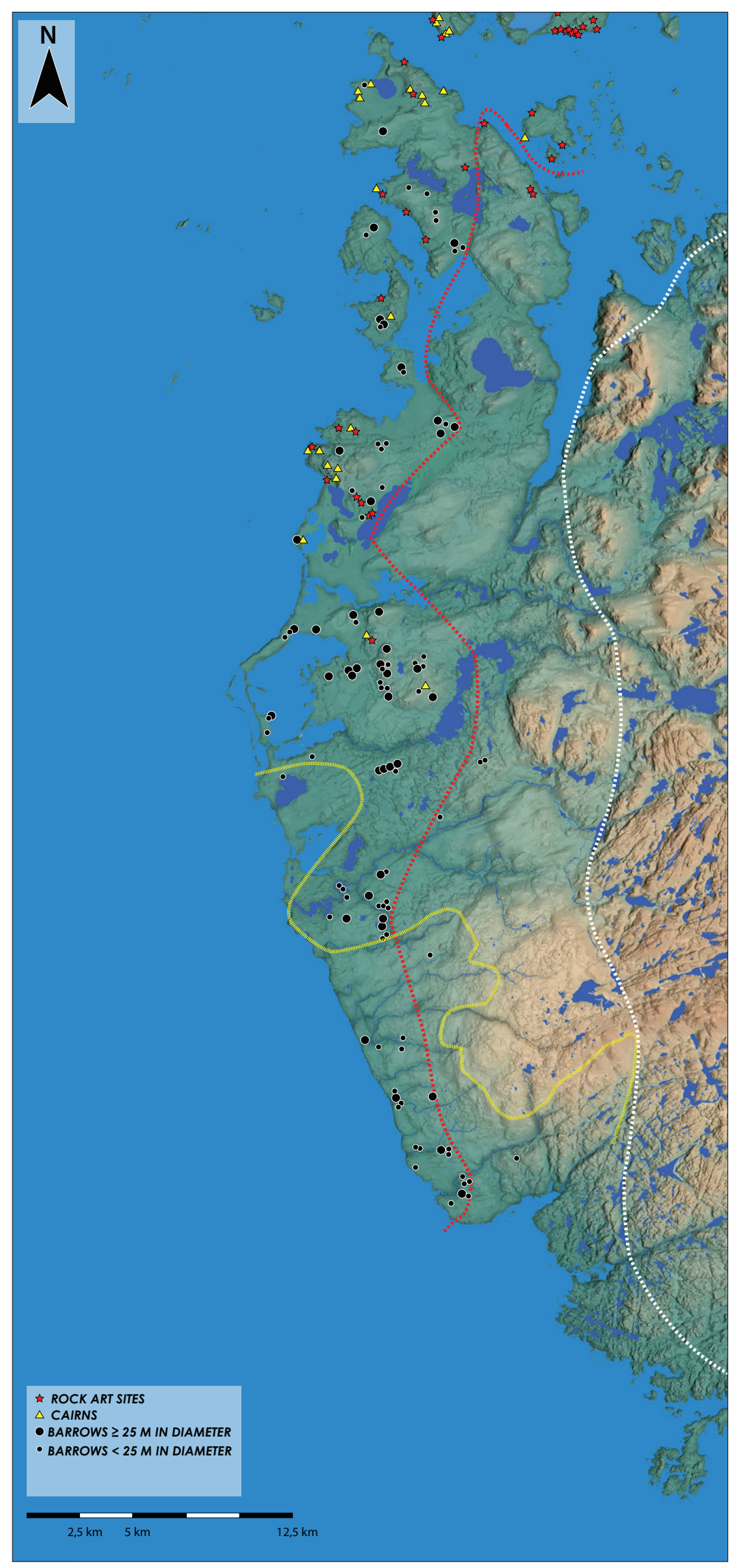


Fig. 4a. Generelt bilde av strandforskyvningsforløpet i Rogaland som viser variasjoner fra nord til sør og fra vest mot øst. Yngre Dryas-transgresjonen og Tapes-transgresjonen krysser hverandre ved Reve og Orrevatn på Midt-Jæren (etter Prøsch-Danielsen, 2006, fig. 59).

Fig. 4a. Map showing the N-S and $W-E$ variations in the sealevel displacement curve for Rogaland. The Younger Dryas and the Tapes transgression intersect near Reve and Orrevatn in Central-jæren (after Prøsch-Danielsen, 2006, fig. 59).

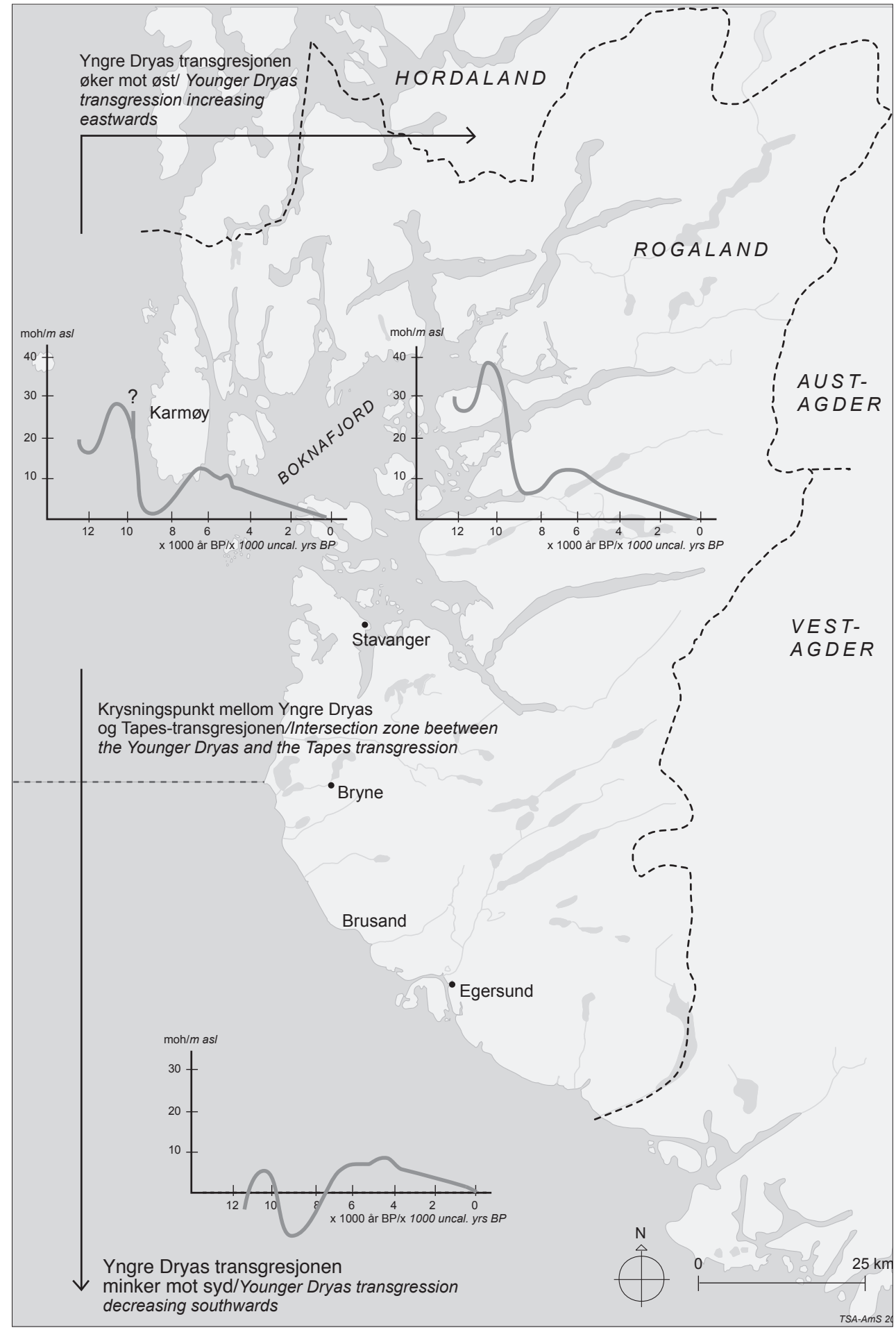

mest karakteristiske avsetningene er de drumlinoide ryggene (sigarformete morenerygger) som strekker seg i SSV-NNØ-retning i området mellom Søre- og Nordre Eigerøya (Garnes, 1976). Et tynt dekke med morene finnes også i daldraget mellom Nonsfjellet og Varberget i Eigersund og slutter som en ring rundt Varberget. Det er i dette området vi finner bergkunstlokaliteten på Husabø (id 71931) og skålgropfeltet ved skolen på Husabø i Eigersund id 43805).
De to bergkunstlokalitetene i Sokndal ligger på bergknauser på hver sin side av elva Sokna. I dalfyllingene er det et tynt morenedekke. I Sokndal sentrum vider dalen seg ut og store flater ses mot Årstad sør for elva og ved Tuen nord for elva. Her er det store vifter med elveavsetninger i bunnen like ved bergkunstfeltet Bø (id 65874). Disse går over i breelvavsetninger lenger oppover langs Sokna ved skolen og Orreberget. Bergkunstfeltet Hanaberg (id 24715) ligger i det sistnevnte området. 


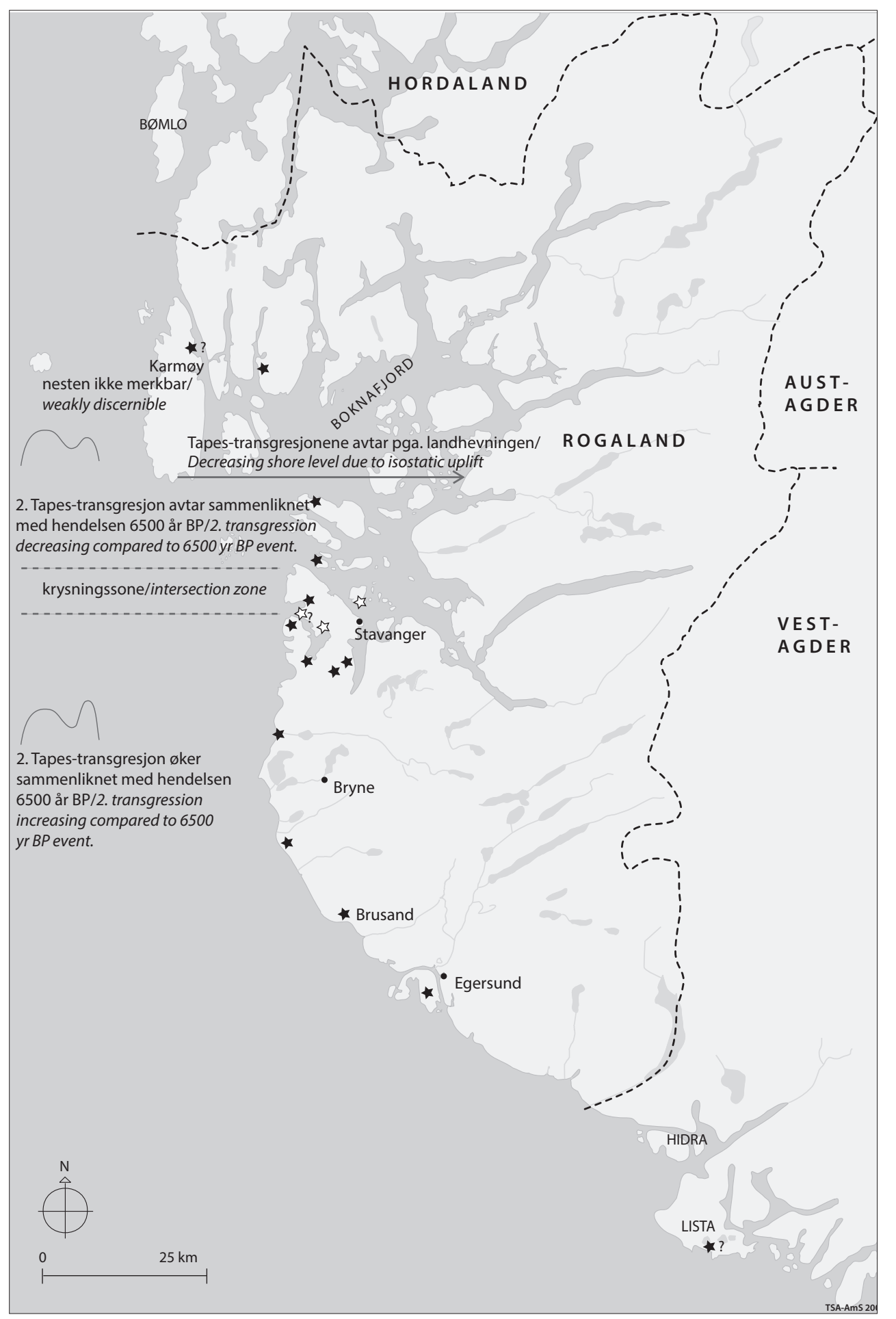

Fig. 4b. Tapes-transgresjonen er to-toppig i deler av Rogaland. Kartet viser hvor de to toppene krysser hverandre ved randaberghalvøya. Nord for Randaberg når den eldste transgresjonen høyest i terrenget, sør for Randaberg er det den yngste transgresjonen som når høyest i terrenget (etter Prøsch-Danielsen, 2006, fig. 8I).

Fig. 4b. Sites with a doublepeaked Tapes transgression (filled stars) in Rogaland. The second transgression increases southwards compared to the first one. The intersection zone is probably close to the Randaberg peninsula (after PrøschDanielsen, 2006, fig. 8I).

\subsection{Strandforskyvning}

Flere forskere betrakter bronsealdersmennesket som sjøfarere med en sterk maritim tilpasning der mobilitet på vann og sjø er en viktig faktor (Bang-Andersen, 1999; L.N. Myhre, 2004; Kvalø, 2007; Austvoll, 2014, 2018).

I tillegg til å forstå utviklingen fram til det mangefasetterte bronsealdersamfunnets karakter (PrøschDanielsen et al., 2018), er det også viktig å ha en forståelse av og å kunne lese landskapet med en sjøfarers briller. Hvor finnes f.eks. aktuelle lune havner og farlige strekninger til sjøs? I flere nordiske arbeider har det vært demonstrert hvorledes bergkunstens plassering er knyttet til datidens havnivå og til knutepunkter i landskapet som fjordarmer, beskyttede havbukter, eid, vannveier og andre kulturminner (Gansum et al., 1997; Helskog, 1999; Ramstad, 2000; Sognnes, 2001, Gjerde, 2002, 2015; Goldhahn, 2002; Ling, 2013, 2014; Wrigglesworth, 2002, 2011) og i vårt område omtalt i 


\section{Alvevatn, Klepp, Rogaland, Norway \\ $10.0 \mathrm{~m}$ asl}

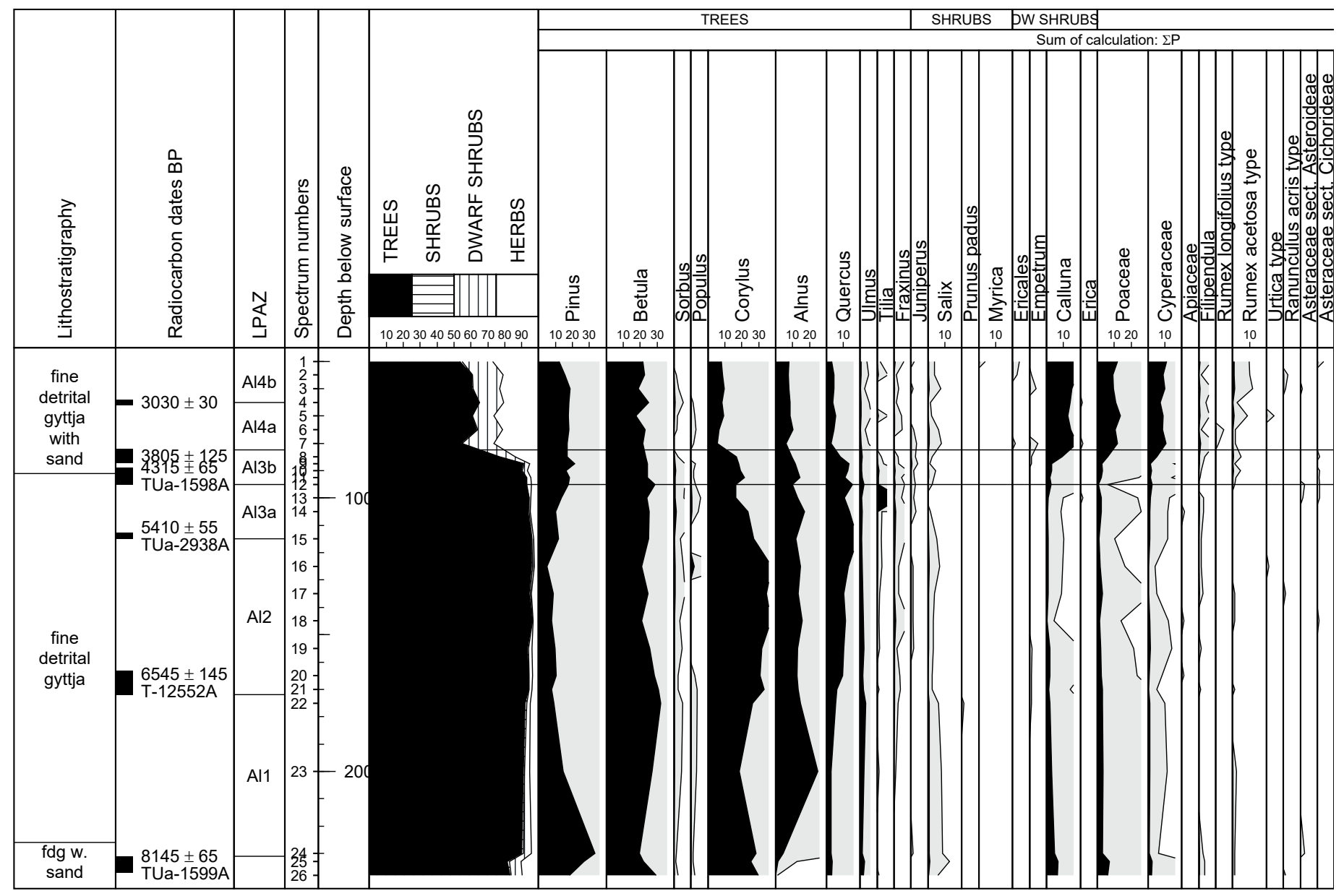

Fig. 5. Prosent-pollendiagram fra Alvevatn som viser to avskogningsfaser; omkring 2965-2900 f.Kr. og 2470-2060 f.Kr. (dvs i neolitikum), markert med horisontale linjer i pollendiagrammet. Økning i røsslyng (Calluna vulgaris) følger skogryddingen (etter Prøsch-Danielsen \& Simonsen, 2000a; Prøsch-Danielsen \& Sandgren, 2003).

Fig. 5. Per cent pollen diagram from Alvevatn. Two forest clearance periods are visible, the first calibrated to 2965-2900 BC (MN), the second one to 2470-2060 BC (LN), marked with horizontal lines in the pollen diagram. Calluna vulgaris rises immediately after the forest clearances (after Prøsch-Danielsen \& Simonsen, 2000a; Prøsch-Danielsen \& Sandgren, 2003).

arbeider av L. N. Myhre (2004), Coles (2005), B. Myhre (2013) og Prøsch-Danielsen et al. (2018).

Felles for mange av arbeidene utenfor Rogaland er at de omtaler ristninger som tilhører den nordlige tradisjonen. Disse ligger i et landskap der landhevningen har vært sterk etter istidens slutt. Strandlinjestudiene har således vært brukt med hell til å datere bergkunstlokalitetenes bakre alder. Ristningene har logisk nok vært hogd høyere opp i terrenget enn der strandlinjen sto til enhver tid. På Jæren og i Dalane regionen er landhevningen mer komplisert, med to transgresjoner og regresjoner etter at området ble isfritt. Det faktum at bergkunst er knyttet til den sørlige tradisjonen, dvs. bergkunsten er knyttet til jordbrukskulturen, betyr at samtlige ristninger ved ytterkysten er skapt under regresjonsfasen etter den yngste Tapes-transgresjonen. I vårt område betyr det at landbremmen stadig økte og at store områder, der havvannet tidligere trengte inn, dukket opp av havet og nye fertile områder ble blottlagt. På Nord-Jæren og i Boknafjordområdet kan flere av bergkunstfeltene knyttes direkte til strandlinjen (Høgestøl et al., 1999, 2006). Bare to av de aktuelle bergkunstlokalitetene sørover på Jæren, Vigdel og Hellestø, kan relateres til datidens strandlinje, mens bergkunsten i Kråkhaug-Valhaug-komplekset samt Sokndal i Dalane-regionen er knyttet til eldre vannveier med innløp fra sjøen. I dag er bergkunstlokalitetenes relasjon til datidens strand og delvis til vannveiene for en del gått tapt av naturlige årsaker, og det skyldes også menneskenes inngrep i form av dreneringer og torvskjæring.

Ytterkysten på Midt-Jæren, på den strekningen der bergkunsten finnes, er i dag svært eksponert. Her mangler skjærgård og lune havner. Med unntak av strekningen 


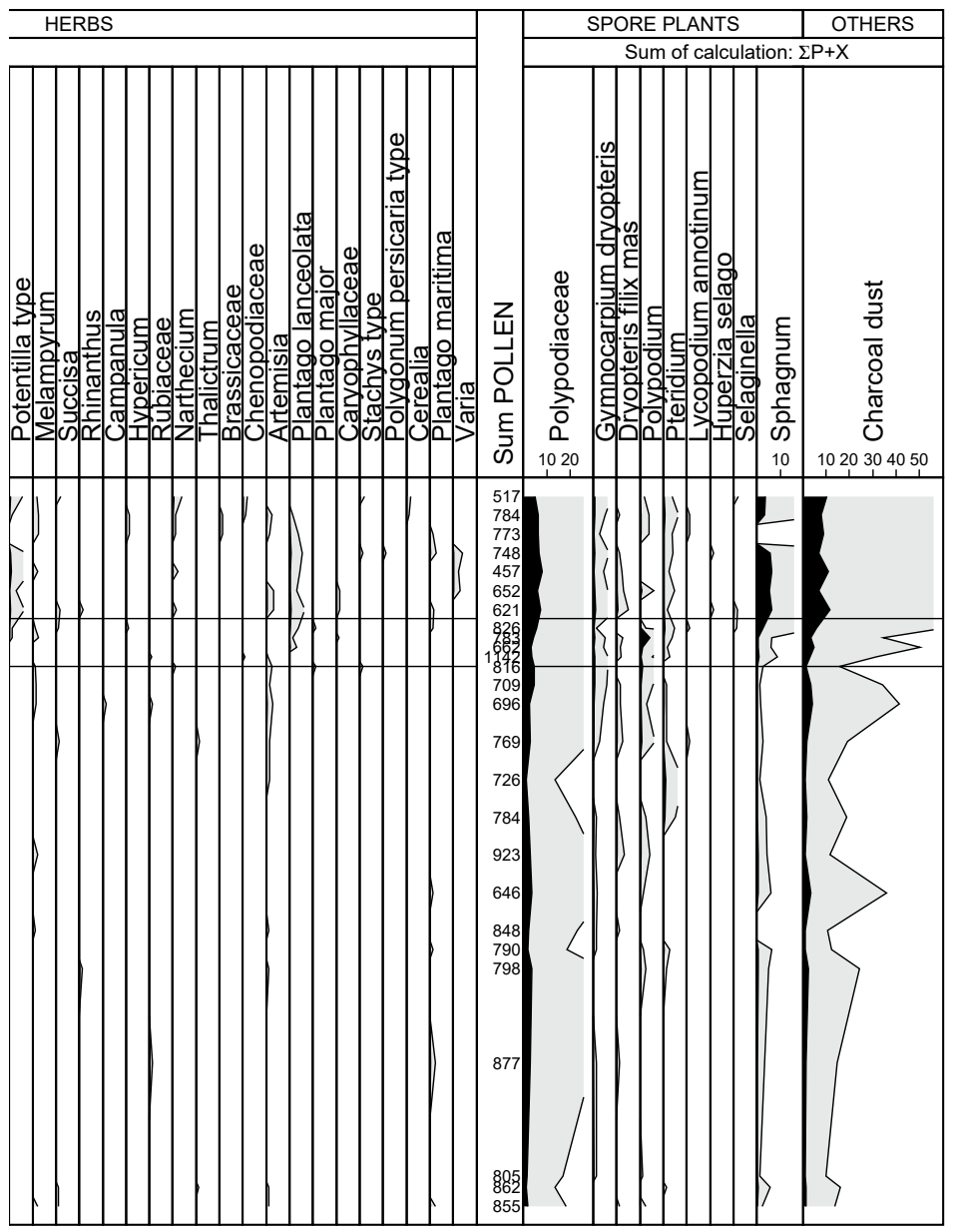

Analysis: Lisbeth Prøsch-Danielsen 1995

fra Ølbør til Hellestø består kyststripa av store, uavbrutte flygesands- og dyneområder (Prøsch-Danielsen \& Selsing, 2009) som sammen med strandvoller demmer opp for store vann som f.eks. Harvalandsvatn, Alvevatn, Orrevatn og Horpestadvatn. Tidligere lå også Mosvatn, Ølstervatn og Tangarvatn/Selevatn i dette området, men disse er i dag tørrlagte ved drenering. I bronsealderen så dette landskapet annerledes ut.

Landbremmen langs Låg-Jæren endres merkbart når kystlinjen heves eller senkes. Særlig gjelder dette i Sola og Klepp kommuner (Fig. 4a). Dette skyldes spesielt fire forhold: Det faktum at landskapet var nedpresset av innlandsisen under istiden, at mengden vann i havet har variert, at landskapet er relativt flatt og lavtliggende og sist, men ikke minst, at store løsmasser stadig var i endring langs kysten. De to førstnevnte forholdene gjelder også for Dalane-regionen. Små hevninger i havnivået fikk store konsekvenser for strandlinjen og resulterte i at store landområder ble oversvømt. Ved Sola flyplass for eksempel, lå strandlinjen ved Stangaland hele $3 \mathrm{~km}$ lengre mot øst om lag 4000 år f.Kr. (Prøsch-Danielsen, 2006). Det motsatte gjaldt ved en senking i havnivået; da økte landbremmen.

Det postglasiale strandlinjeforløpet i Rogaland ble sammenstilt i 2006, basert på feltrapporter, publiserte og upubliserte arbeider fra arkeologiske og naturhistoriske undersøkelser (Prøsch-Danielsen, 2006). Av betydning for vårt arbeid er kunnskapen om den siste transgresjonen (Tapes-transgresjonen) med maksimum omkring 5400 f.Kr., og den påfølgende regresjonen inn i yngre steinalder og videre inn i bronsealder som nevnt tidligere. I de seinere årene har en vært klar over at Tapes-transgresjonene hadde et to-toppig forløp (Bird \& Klemsdal, 1986; BangAndersen \& Thomsen, 1993; Prøsch-Danielsen 1993, 2006). De to transgresjonsmaksima opptrådde henholdsvis omkring 5400 f.Kr. og omkring 4000 f.Kr. Disse transgresjonstoppene krysset hverandre i området ved stavangerhalvøya. Både på Midt-Jæren og i Dalane-regionen var således den yngste toppen høyest (Fig. 4b). Etter dette sank strandlinjen jevnt til dagens nivå. Havnivået sto omtrent $5 \mathrm{~m}$ høyere enn i dag langs Midt-Jæren, og dette ga et mer oppstykket landskap med lune havneforhold der man kunne søke ly med sin båt. Ved inngangen til yngre bronsealder sto havnivået om lag 3-2,5 m høyere enn i dag, og landbremmen var mindre.

Flere detaljstudier vil bli gitt under den enkelte lokalitet der dette har hatt betydning for tolkingen av bergkunstens alder.

\subsection{Vegetasjonsutviklingen de siste $\mathbf{6 0 0 0}$ årene - jordbrukslandskapet oppstår}

En viktig faktor for å kunne lokalisere ristninger tilhørende den sørlige tradisjonen i Norge er tilknytning og nærhet til gode bosetnings- og jordbruksområder og ofte også nærhet til andre kulturminner som gravhauger (se bl.a. Mandt, 1972, 1991; Sognnes, 1984, 1987, 2001; Myhre, L. N. 2004; Mandt \& Lødøen, 2004, s. 243-251, s. 279-287; Prøsch-Danielsen et al., 2018).

I dag tilhører Midt- og Sør-Jæren og Dalane-regionen kystlyngheiseksjonen slik den er definert av Moen (1999) (Fig. 1). På Jæren danner kystlyngheiseksjonen et særdeles bredt belte som karakteriseres som et åpent lyngkledd landskap dominert av ulike utforminger av gress- og lyngheier. Alle bergkunstlokalitetene ligger innenfor kystlyngheiene. I Dalane-regionene smalner dette beltet inn og strekker seg knapt en mil inn i landet. Klimatisk sett er området karakterisert av et oseanisk klima som er avgjørende for opprettholdelsen av kystlyngheiene. Kystlyngheiene er et resultat av avskoging, avsviing og et sterkt beitepress og er et synlig bevis for menneskenes omforming og manipulering i landskapet for å skaffe 
bedre beiter for byttedyr, seinere husdyr og oppstarten til en jordbrukskultur. Begynnende avskoging kan registreres tilbake til 4000 f.Kr. (og på ytterkysten tilbake i sein-mesolitikum), mens åkerbruket tidligst ekspanderer rundt 2300 f.Kr. (Høgestøl \& Prøsch-Danielsen, 2006; Prøsch-Danielsen et al., 2018; Hjelle et al., 2018).

For bare 50 år siden var landskapet, spesielt på LågJæren, variert og besto av en mosaikk av myrer, lyngheier og mesotrofe vann. I dag er området sterkt oppdyrket, og lite av kystlyngheiene er tilbake. Beite av både storfe og småfe, i tillegg til gjødsling, har omformet lyngheiene til gressmarker, og gjødsling har ført til eutrofe (næringsrike) vann og gjengroing av våtmarksområder. I tillegg har nesten samtlige vann, særlig i Klepp kommune, blitt nedtappet og/eller uttappet og blitt totalt tørrlagte.

Avskogingsforløpet på Jæren er basert på pollenstudier fra 26 lokaliteter og fra fire lokaliteter i Dalaneregionen (Prøsch-Danielsen \& Simonsen, 2000a, 2000b). Avskogingene er knyttet til neolittiserings-prosessen (utviklingen av jordbrukskulturen). Avskogingsforløpet var metakront i Rogaland og skjedde i tre markante trinn på Jæren:

- 4000-3600 år f.Kr. (overgangen mesolitikum/ tidlig-neolitikum)

- 2500-2200 år f.Kr. (overgangen mellom-neolitikum II/ sein-neolitikum)

- 1900-1400 år f.Kr. (periodene sein-neolitikum og inn t.o.m. bronsealderens periode II)

Pollendiagrammer fra Midt-Jæren viser at det fantes en tett skogsvegetasjon i dette området som besto av bjørk, hassel, furu og or fra omkring 7100 f.Kr. til 5400 f.Kr. Denne skogstypen ble etterfulgt av en mer varmekjær type der også eik, lind, ask og alm var representert, seinere av en pionerskog med hassel, bjørk og or. Det viser seg at avskogingen først startet, relativt seint, i det andre av disse trinnene på Midt- og Sør-Jæren, altså først ved overgangen fra mellom-neolitikum II til sein-neolitikum. Fra da av skjedde avskogingen raskt og nådde midtveis på Jæren ved overgangen mellom eldre og yngre bronsealder (Fig. 3) (Prøsch-Danielsen et al., 2018). Det betyr at hele området der vi finner bergkunstlokaliteter, samt store monumentale gravhauger fra bronsealderens periode II og III, allerede var avskoget i løpet av eldre bronsealder.
Gravhauger var dermed lett synlige i terrenget, og utsikten fra bergkunstlokalitetene mot sjø, vann og knutepunkter i terrenget var god. Gjennom yngre bronsealder og jernalder fortsatte avskogingen østover.

Det mest sentrale pollendiagrammet for bergkunstlokalitetene på Midt-Jæren er diagrammet fra Alvevatn i Klepp kommune (Fig. 5) (Prøsch-Danielsen \& Simonsen, 2000a, 2000b; Prøsch-Danielsen \& Sandgren, 2003). Her skjedde avskogingen brått og ble direkte fulgt av lynghei. Hendelsen er datert til (T-12550A) 2470-2060 f.Kr. i Alvevatn. I Alvevatn er det også svake spor etter en begynnende rydding litt tidligere, datert til (TUa-1598A) 2965-2901 f.Kr., dvs. ved overgangen mellom-neolitikum periode I og II. På Midt-Jæren var sluttproduktet kystlynghei omkring 800 f.Kr. Avskogingen på Midt-Jæren startet med andre ord om lag 2500 f.Kr., da jordbruket fikk innpass for fullt (Høgestøl \& Prøsch-Danielsen, 2006), og var fullført omkring 900 til 700 f.Kr., dvs. i bronsealderens periode V. Indre deler av Midt-Jæren besto av en mosaikk av skogholt og lynghei på det tidspunktet da bergkunstlokalitetene ble laget, men ute ved kysten var det fritt for skog (Fig. 3). På Sør-Jæren tok lyngheiene over først om lag 200 f.Kr.

Det finnes dessverre bare et fătall pollendiagrammer fra Eigersund- og Dalane-regionen. I Eigersund er det utarbeidet tre pollendiagrammer fra Eigerøya som kan være representative for området (Prøsch-Danielsen \& Simonsen, 2000a, 2000b), og i Dalane er det nærmeste diagrammet fra Svartetjørn om lag $5 \mathrm{~km}$ i luftlinje vest for bergkunsten i Sokndal (Høeg, 1999). Alle disse diagrammene er laget fra bassenger innen anortosittprovinsen.

I Eigersundområdet starter avskogingen relativt seint, i det andre av avskogingstrinnene, altså først ved overgangen fra mellom-neolitikum II til sein-neolitikum. Til forskjell fra Midt-Jæren foregår avskogingen her langsomt over omlag 2000 år, og lyngheilandskapet trer først fram om lag 200 f.Kr. I Dalane, derimot, starter avskogingen allerede ved inngangen til tidlig-neolitikum datert til omlag 3500 f.Kr., men ender i likhet med Eigersundlokalitetene ikke opp med lynghei som sluttprodukt før om lag 200 f.Kr. Det betyr at området ikke har vært helt skogløst gjennom bronsealderen da menneskene ristet inn sine figurer på bergknausene, verken $\mathrm{i}$ Eigersund eller i Sokndal. 


\section{Sola kommune}

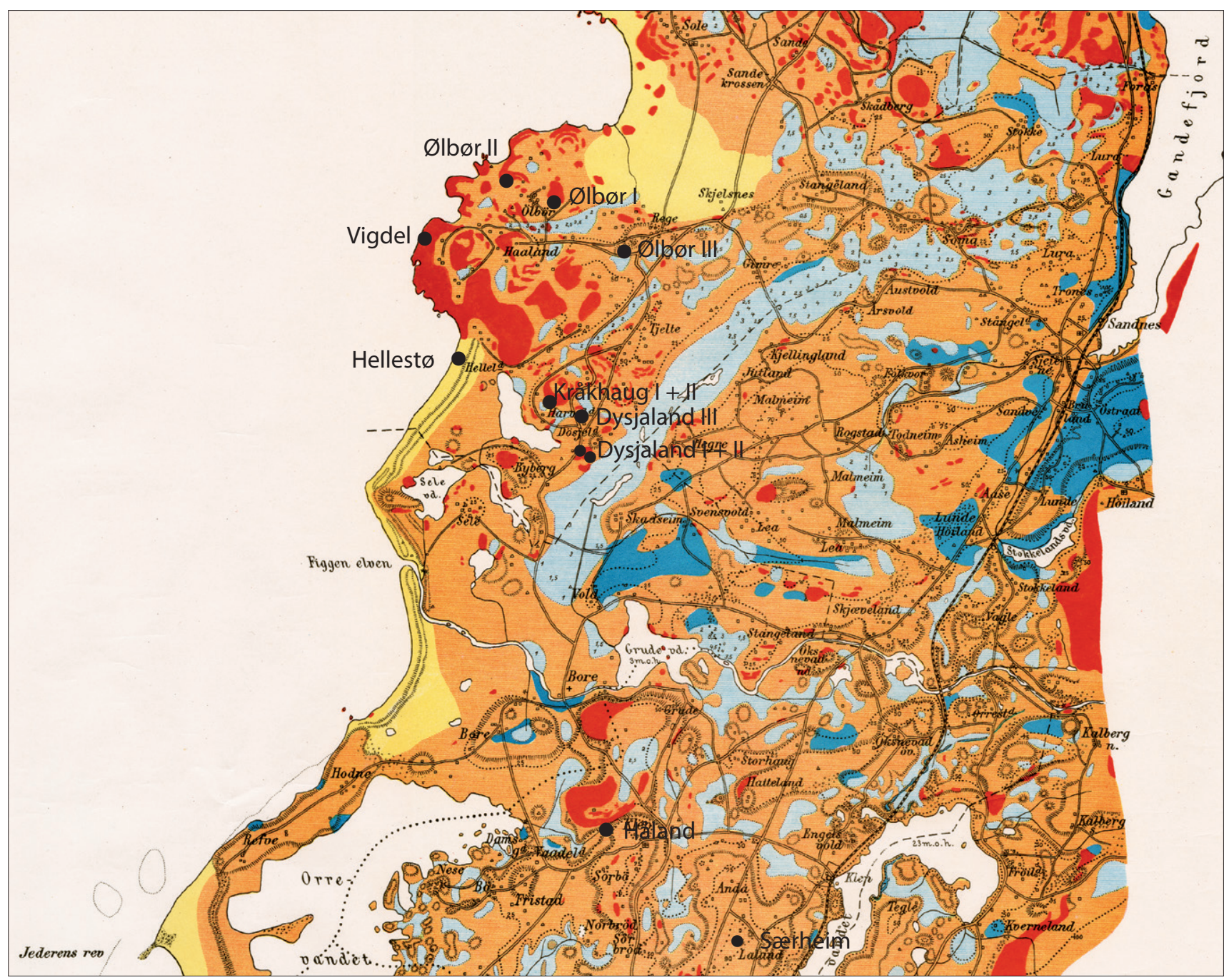

Fig. 6. Kart som illustrerer vekslingen mellom bart fjell (rødt) og løsmasser i Sola kommune i 1910. Kartet viser også myrer (lys blått) og vann som i dag er tørrlagte og uttappede (etter Grimnes, 1910). Bergkunstlokalitetene er markert med sorte punkter. Fig. 6. Part of Grimnes map of 1910 showing the different soil conditions in the Sola municipality. Exposed bedrock (red), sandy soils (orange), eolian deposits (yellow), soils with a high clay content (dark blue) and mires and drained lakes (light blue). The rock art sites are marked with black dots.

\section{I Bergkunstlokaliteter}

\section{I.I ØLBØRKOMPLEKSET}

Ølberg gnr. 20, bnr. 12, 73 - «Ølbør I», Id 34980

Historikk, beliggenhet og presentasjon

av lokalitet og figurer

Lokaliteten som ble registrert av Helliesen (1902, s. 62) (se Fig. 6 og 7) og av Brøgger i 1910 (1910a) og lå like ovenfor ei nå drenert myr, besto av sju enlinjete skip samt ei enkel linje hogd inn på en «pyramideformet» steinblokk. Ett av skipene (nr. 4) har utsvingte, mens seks har innsvingte, høye stavner. Videre har de en rett eller lett rett kjølforlenger foran samt en stabilisator akter. Med unntak av skip nr. 4 ser flåten ut til å seile mot høyre, og lokaliteten framstår som en helhetlig komposisjon. Skipene er ifølge Kaul (2004, s. 371) av samme form som skipene på Rørbysverdet, funnet i Vest-Sjælland, Danmark og kan derfor dateres til eldre bronsealder. Innen vestnorsk klassifikasjon kan de fleste karakteriseres som B2-skip 
Fig. 7. Bergkunstfeltet Ølbør I (etter Helliesen, 1902, fig. I).

Fig. 7. The rock art site Ølbør I (after Helliesen, 1902, fig. I)

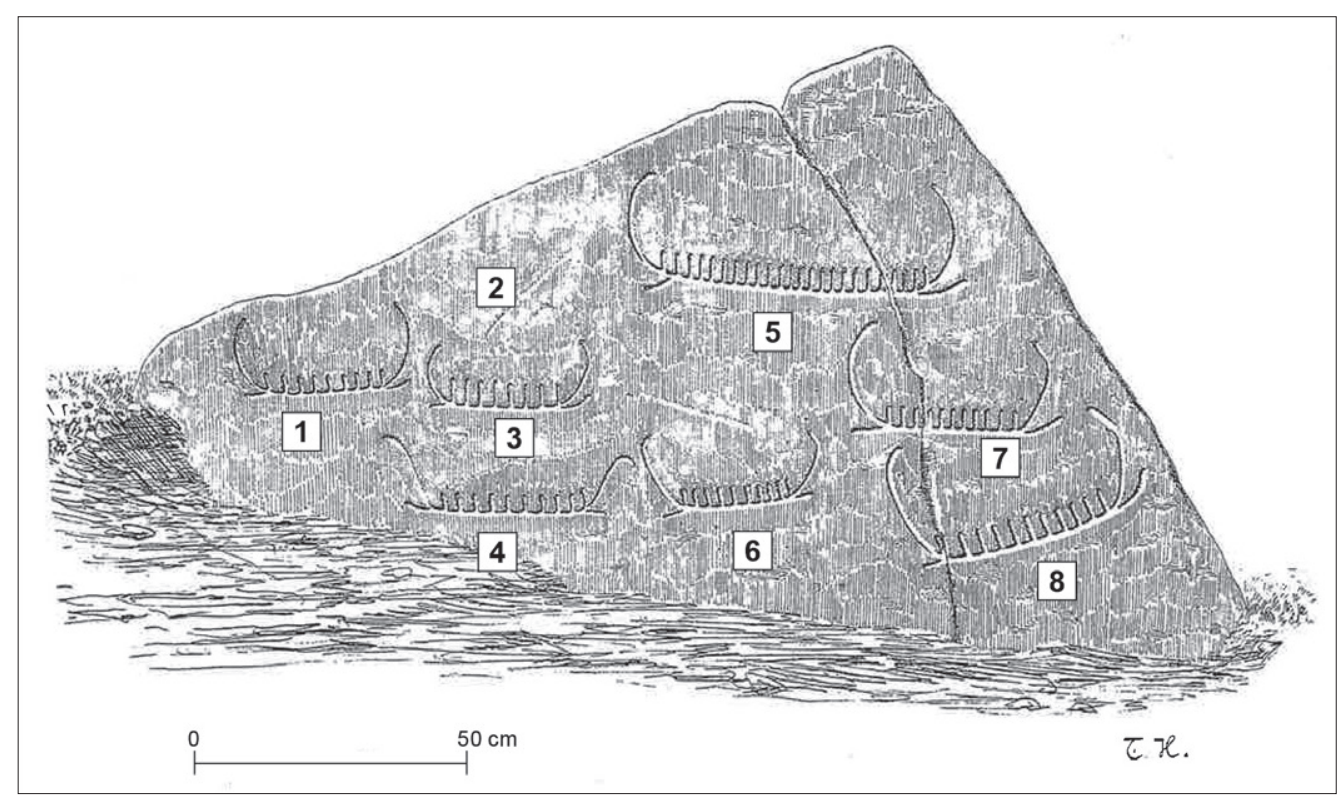

(Mandt, 1991, s. 47) der brukstiden ligger innenfor bronsealderens periode II til IV/V (Wrigglesworth, 2011, s. 118).

Da E. Fett og P. Fett (1941) gjennomførte bergkunstarbeid i området i 1933, var lokaliteten alt sprengt bort. Brøgger skriver (sammenligning mellom hans og Helliesens dokumentasjon): «Stenens dimensjoner og tegningen av skibene er rigtig gjengit og stemmer ganske med min undersøkelse av 9. august 1910. Den vender facaden mot vest. Skibene er smukt indhugget og nogenlunde vel bevart, saa der var ingen vanskeligheter med at tyde figurene» (1910a). Som E. Fett og P. Fett (1941, s. 81) også påpeker, er tegningene nokså ens, bortsett fra at Brøgger i skip nr. 4 istedenfor to mannskapsstreker har kalkert en adorant samt at Brøgger har markert et usikkert linjestykke i høyre stavn på figur 5 .

\section{Ølberg gnr. 20, bnr. 1, 17 - «Ølbør II» («Mælen»), Id 14873}

Historikk, beliggenhet og presentasjon av lokalitet og figurer

Lokaliteten som består av to skip, ble registrert og dokumentert av Helliesen (1902, s. 62), befart og kalkert på nytt av Brøgger (1910a) og av E. Fett og P. Fett (1941, s. 81) (Fig. 8, se også Fig. 6). På lokaliteten som ligger om lag $200 \mathrm{~m}$ fra sjøen og om lag 45 m nordøst for bolighus på gnr. 20/1,65, er figurene hogd ca. 2 m over bakkenivå på sørøstsiden av en $4 \mathrm{~m}$ høy fjellknaus i beitemark. Bergveggen er nesten

Fig. 8. Ølbør II (id I4873).

De to skipene ses øverst i bildet.

Foto: E. og P. Fett. Fig. 8. The rock art site Ølbør II. The carved figures of two ships are traced by chalk, seen in the upper part of the picture. Photo: E. and P. Fett.

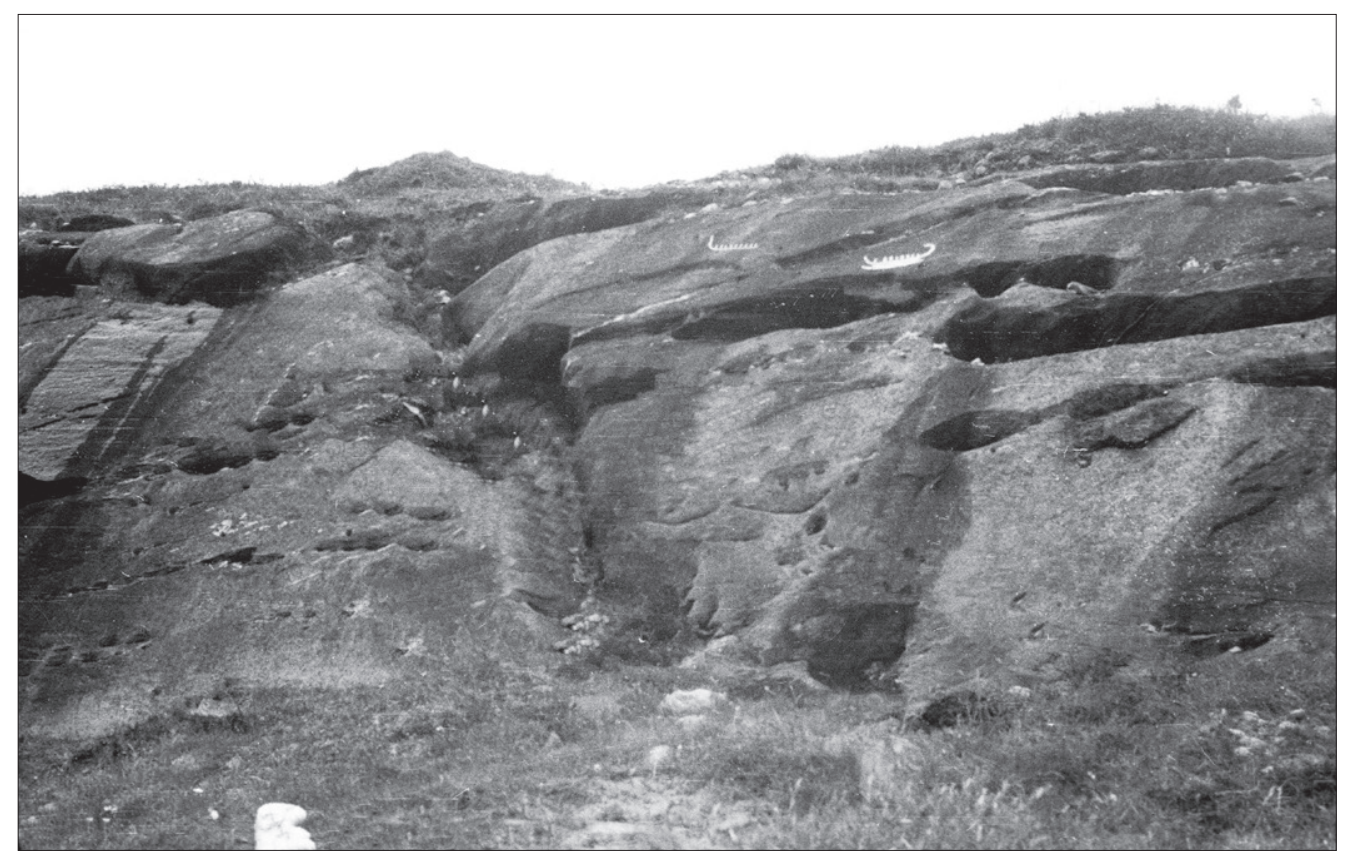




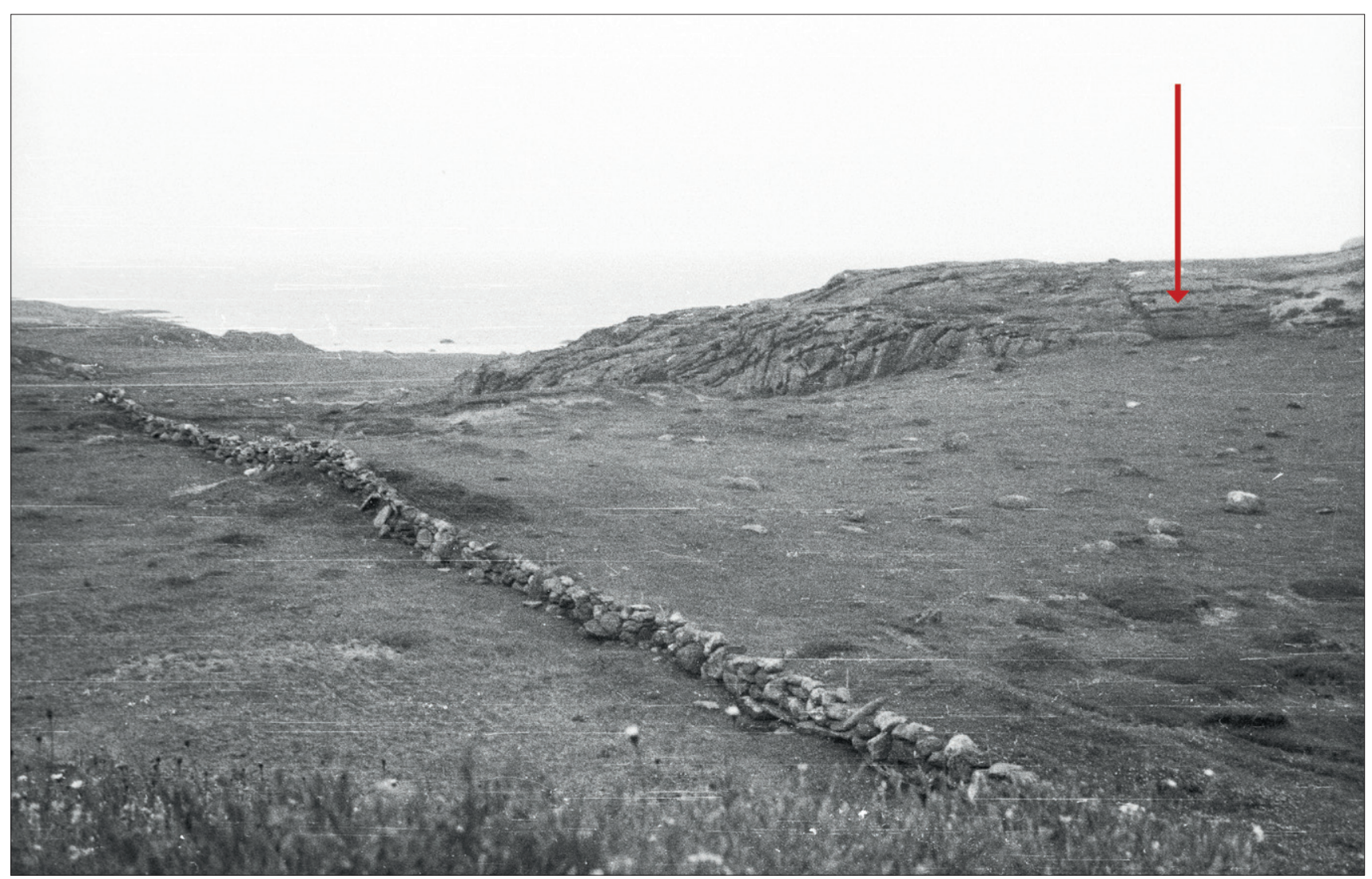

Fig. 9a. Landskapet omkring Ølbør II på 1930-tallet. Foto: E. og P. Fett.

Fig. 9a. The landscape in the vicinity of the Ølbør II carved figures. Photo from the 1930s. Photo: E. and P. Fett.

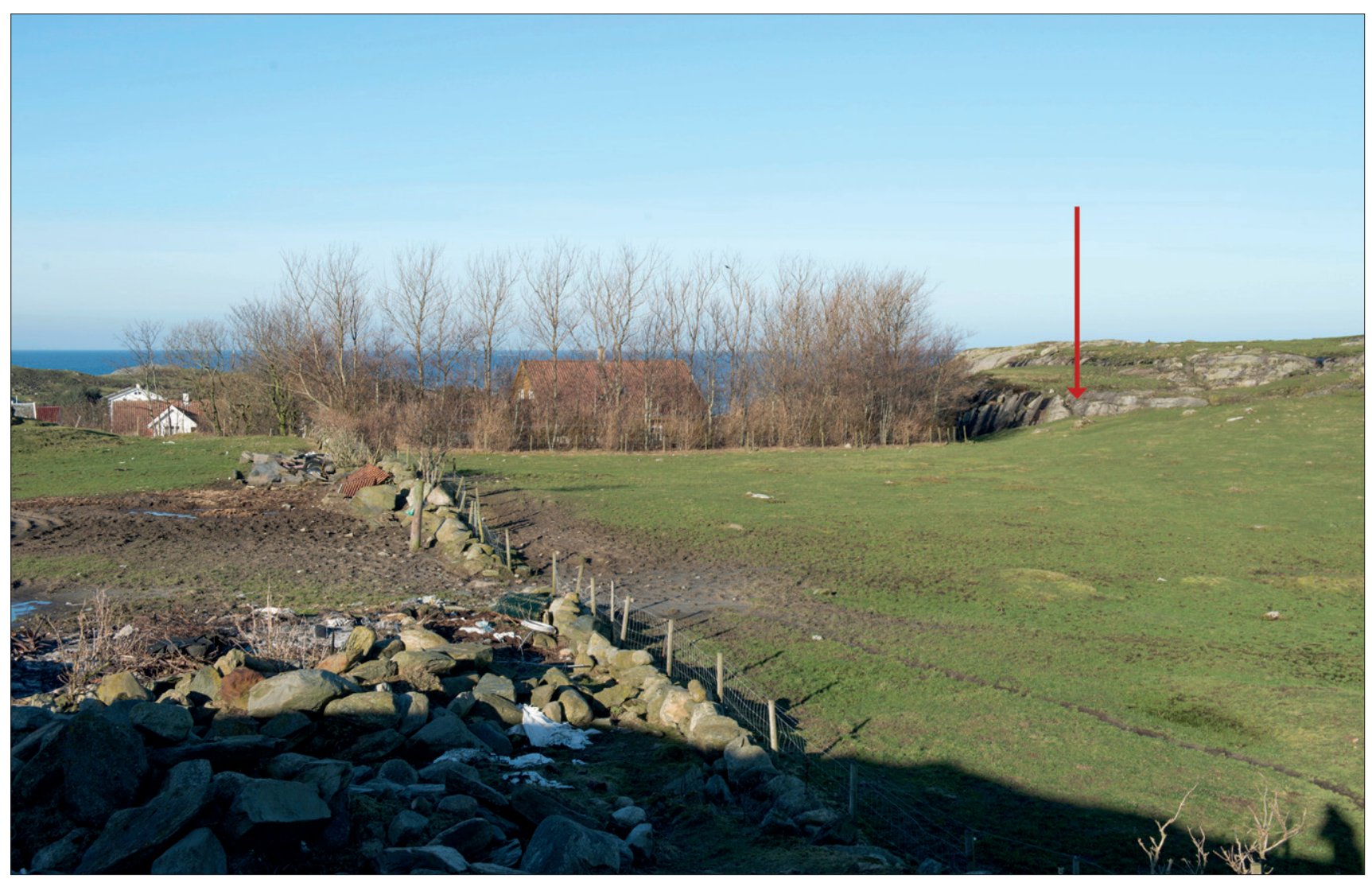

Fig. 9b. Landskapet omkring Ølbør II i 20I5. Foto: $\AA$. Pedersen, AM, UiS.

Fig. 9b. The landscape in the vicinity of the Ølbør II carved figures. Photo from 2015. Photo: $\AA$. Pedersen, AM, UiS. 
vertikal nederst, faller 40-50 der figurene er hogd, og flater så ut øverst. Brøgger skriver i 1910: «Ute i den kollede kyststrækning ved Ølberggaardene er ogsaa en liten fjeldkolle, som kaldes «Mælen». Herfra har Helliesen, Ølbør p. 62 en liten helleristningsfigur, et skib. Ligger i sydlige fjeldvæg. Undersøktes av mig 9 aug. Silkepapirtegning foreligger. Stemmer med Helliesens figur 6, sammesteds». Selv om Helliesen avtegnet to skip (1902, s. 64, fig. 6), nevnes bare det ene i rapporten «Oldtidslevninger i Stavanger amt» (1902, s. 62), og heller ikke Brøgger nevner det andre skipet i ovennevnte innberetning. Den «utelatte» figuren (nr. 1) er svakt hogd, enlinjet og en stavn mangler. Det er imidlertid vanskelig å avgjøre om den kun er påbegynt eller om stavnen er vitret bort. Det andre skipet (nr. 2) som er tolinjet, er hogd dypt og kan klassifiseres som et A2-skip (Mandt, 1991, s. 47) hvor brukstida ligger innenfor bronsealderens periode I til IV (Wrigglesworth, 2011, s. 118). I følge Ling sin skipskronologi er dateringen eldre bronsealder (2014, s. 105, nr. 10). Begge skipene ser ut til å seile mot venstre.

Det grunneste enlinjete skipet (nr. 1) er vanskelig å observere ved dårlige lysforhold. Figuren ble da heller ikke sett ved ØK-registreringen i 1991 (Trøim \& Henriksen 1991a), men ved befaring i 1998 ble den gjenfunnet, trolig fordi regn den dagen framhevet relieffet (Bakkevig, 1998a).

Da E. Fett og P. Fett dokumenterte lokaliteten på 1930-tallet, lå lokaliteten fritt med utsyn mot havet, i dag er den i større grad skjult av bebyggelse (Fig. 9a og 9b).

\section{Bergart, geologisk vitring og slitasje}

Bergarten er en finlaminert kvartsrik glimmergneis. Bergveggen består av tilsynelatende solide, men noe ujevne partier mellom opptil flere $\mathrm{dm}$ dype og i noen tilfelle meterlange langsgående groper. Gropene er dels fuktige og delvis fylte med gress og andre planter.

Overflaten der skipsfigurene er hugget er nokså glatt med enkelte noe oppragende mineralkorn, men uten sprekker eller andre synlige skader. Vann siger nedover figurene, noe som kan føre til frostsprengning.

\section{Endring over tid og skader påført av mennesker}

E. Fett og P. Fett (1941, s. 81) beskriver fjellet som «skifrig med mange avskallinger og en ujevn overflate». Sømme Dahl (1985) skriver at fjellet ved selve skipet ser relativt fast og jevnt ut, men både over og under er det erosjonstegn. Under det østligste skipet er det et hulrom som er $45 \mathrm{~cm}$ dypt og over et hakk som er $20 \mathrm{~cm}$ dypt. Vest for skipet er det videre rader av små hull. Sømme Dahl oppfatter denne som en svært truet ristning. Ved ny befaring i 2011 kunne en imidlertid konstatere at begge skipene er tilstede, og at de ikke er påført skader. De ligger godt beskyttet mot husdyr som går i området, og selv om det er kort avstand til et lite boligfelt, er det ingen indikasjoner på at ristningene er utsatt for slitasje (Bakkevig, 1998a).

Figurene ble krittet opp i forbindelse med E. Fett og P. Fett sin kalkering i 1933 (1941, s. 81), men de er aldri blitt påført maling.

\section{Ølberg gnr. 20, bnr. 12,15, 56 - «Ølbør III», Id 14899}

\section{Historikk, beliggenhet og presentasjon av lokalitet og figurer}

Lokaliteten ble påvist i 1992 av en privatperson, og samme år ble lokaliteten registrert og dokumentert (Hernæs, 1992a). Figurene er hogd i en tilnærmet loddrett flate på vestsiden av en øst-vestgående bergrygg om lag $20 \mathrm{~m}$ nord for Gardshaugvegen, om lag $150 \mathrm{~m}$ øst for driftsbygningen på gården og om lag $40 \mathrm{moh}$. Lokaliteten var tidligere vendt mot ei nå drenert myr (se Fig. 6). Hernæs registrerte 19 figurer, hvorav seks sikre og en mulig skipsfigur, en, muligens to, hestefigurer, sju skålgroper samt endel ubestembare linjer. Seinere er det også påvist et mulig skip samt en mulig ringfigur som omslutter ei av skålgropene og i tillegg tangerer to av dem. Så vel skipet som ringfiguren er lokalisert over øverste skip på lokalitetens høyre del (Fig. 10).

Alle skipene er enlinjete med mannskapsstreker. På høyre del av bergflaten er det to skip hvor samme relingslinje dels er benyttet. Ett har høye stavner, ett har lave. Nedenfor finnes også to skip som er hogd over hverandre. Dette indikerer at figurene ikke er hogd samtidig, men hvor lang tid det har gått mellom de to begivenhetene er vanskelig å avgjøre. Det kan også se ut som at enkelte av skipene kun er påbegynt, men ikke fullført. Skipene kan klassifiseres som B3- og B4-skip (Mandt, 1991, s. 47) og dateres dermed til yngre bronsealder (Wrigglesworth, 2011, s. 118). Skipene kan også sammenlignes med nr. 18 i Kaul sin skipskronologi $(1998$, s. 88) der dateringen er yngre bronsealder, periode IV. Videre, med unntak av ett skip, seiler hele flåten mot venstre.

Hernæs (1992a, s. 8) påviste en hestefigur og skriver at like under finnes nok en hestelignende figur, men denne mangler bein. Figuren like under kan vanskelig tolkes som en hest, mens figuren til høyre for hjulkorset er en hest der bakbeinet smelter sammen med hjulkorset; det kan m.a.o. tolkes dithen at hesten trekker hjulkorset (se Fig. 11). Slike solhester forekommer sjelden. Fra Bohuslän, Sverige er det kjent elleve fra ni lokaliteter der det er en forbindelse mellom hesten og solsymbol i form av skålgroper, sirkulære figurer eller hjulkors. I tillegg er det påvist en mulig solhest i Nord-Trøndelag der en 


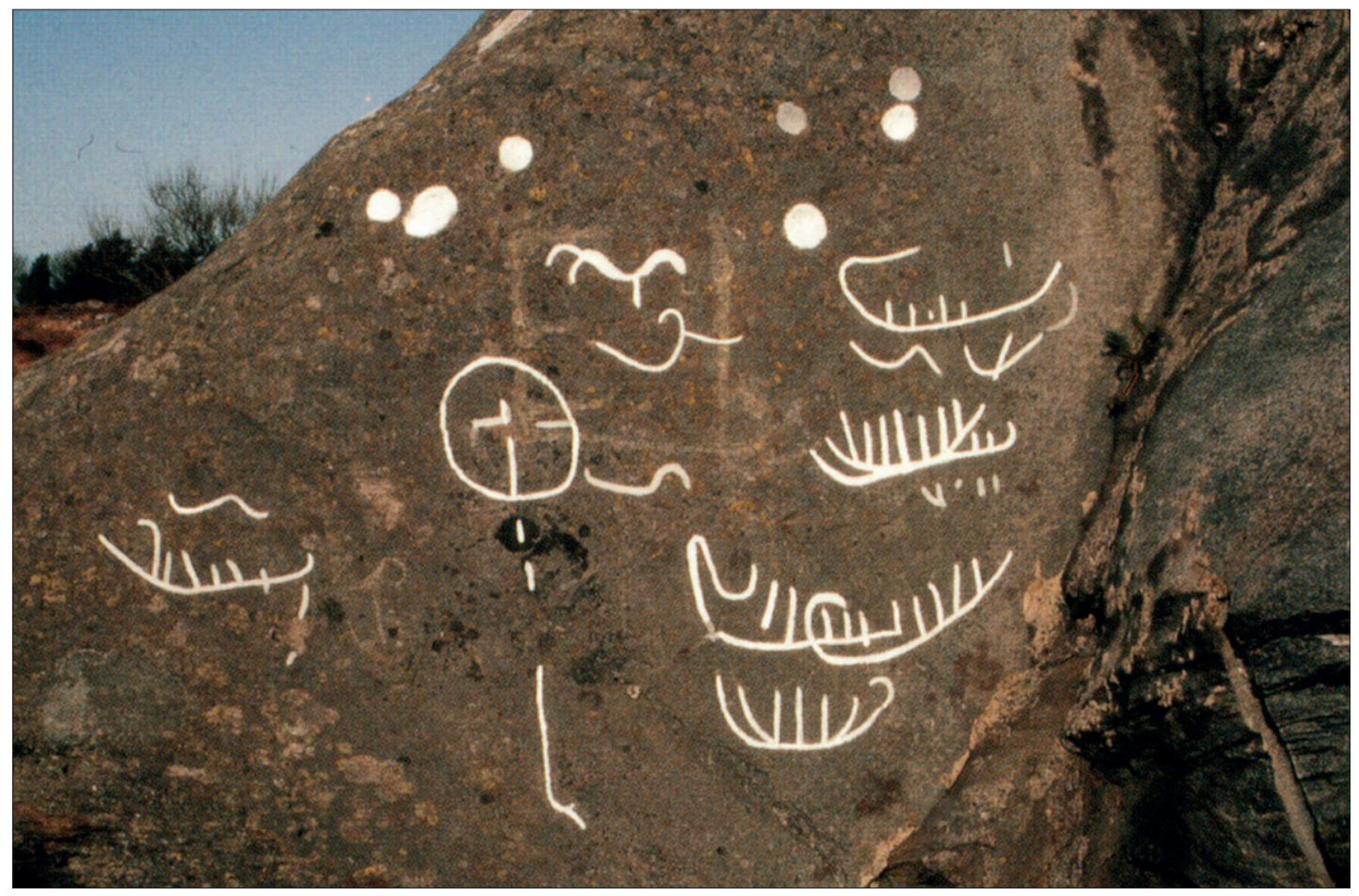

Fig. 10. Ølbør III (id 14899) etter oppmaling i 1992. Foto: P. Hernæs, AM, UiS. Fig. 10. The rock art site Ølbør III after being painted in 1992. Photo: $P$. Hernæs, AM, UiS.

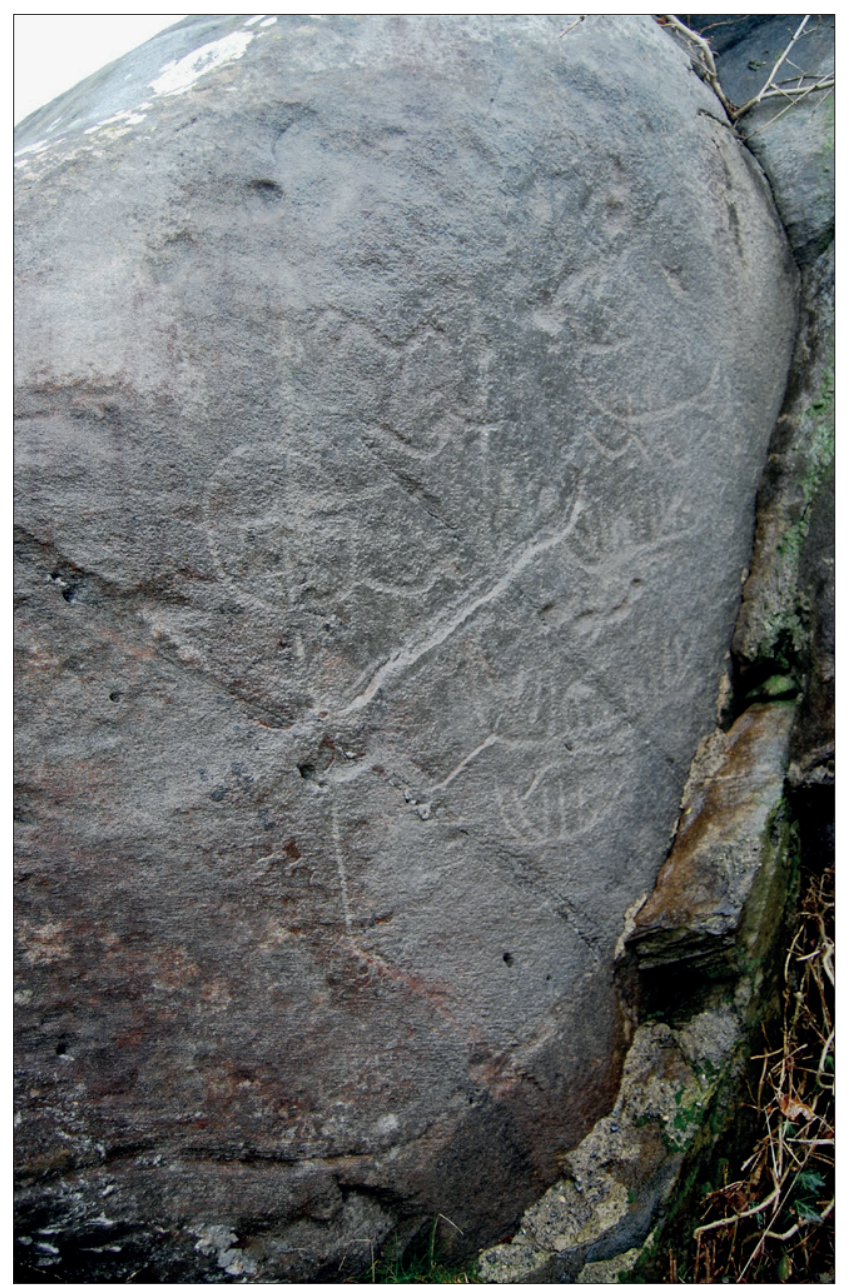

Fig. II. Ølbør III 2009. Foto: L. Prøsch-Danielsen, AM, UiS. Fig. II. The rock art site Ølbør III in 2009. Photo: L. PrøschDanielsen, AM, UiS. stilisert hest trekker et ovalt formet hjulkors. I Danmark kjennes slike solhester fra elleve rakekniver (Kaul, 2004, s. 281) og Kaul daterer dem til yngre bronsealder. Bortsett fra den mulige solhesten i Nord-Trøndelag er de øvrige solsymbolene som trekkes av en hest av langt mindre omfang enn denne på Ølberg. Over eller på hesten på Ølberg er det en svakt hogd rombeformet figur. En alternativ tolking er at dette symboliserer et menneske, og at de to forreste beina tilhører dette individet og ikke hesten. Videre er det hugget en, om ikke sammenhengende, linje eller stake, ned fra hjulkorset, samlet kan dette tolkes som framstilling av en solholder, jf. solholder med hjulkors av bronse og rav, funnet i Danmark (Kaul, 2004, s. 358). Framstillingen kan gi rom for ulike tolkinger: solhest, rytter på hest, eller en rytter på hest som trekker solskiva/solholderen.

Hestefigurene var forøvrig fram til nytolking av «glemt figur» på Dysjaland II (se id 5528), og en mulig hestefigur på Vigdel (id 34984), de eneste kjente fra Rogaland. Videre, i skipet på venstre del av bergflaten, kan en av mannskapsstrekene tolkes som lurblåser, muligens kan de bølgeformete linjene under det øverste skipet til høyre i bildet og over skipet til venstre, tolkes som slangefigurer, og kan linjene under den øverste hestefiguren symbolisere en fugl? Lokaliteten består dermed av 20, muligens 22, figurer og linjer (sml. Fig. 10 med Fig. 11).

Ølbør III er en lokalitet med få figurer, men med stor motivvariasjon. Skip, solsymboler som svever over skipene, hester, solholder og muligens menneske-, slange- og fuglefigurer gjør lokaliteten spesiell i rogalandssammenheng. 
Fig. 12a. Tynnslipbilde av glimmergneis fra Ølbør III tatt med planpolarisert lys. Hvite områder består av kvarts og i mindre grad albitt. Avlange hvite til grålige korn med kløv er muskovitt, mens de brune til svarte avlange kornene er biotitt. Det dråpeformete kornet med høyt relieff nær øvre billedkant og noe til høyre for midten er titanitt. Sprekker og porer etter oppløst karbonat er blå. Foto: O. Walderhaug. Fig. 12a.Thin-section micrograph of gneiss from Ølbør III taken in planepolarized light. White areas consist of quartz and albite. Elongate white to pale grey grains with distinct cleavage are muscovite, brown to black elongate grains are biotite. The wedge-shaped grain with high relief located near the top of the micrograph and somewhat to the right of the center is sphene. Fractures and dissolution pores after carbonate are blue. Photo: 0 . Walderhaug.

Fig. 12b. Tynnslipbilde av glimmergneis fra Ølbør III tatt med kryssede polarisasjonsfiltre. Korn av kvarts og albitt er hvite, grå eller svarte. Muskovitt er gul, rosa og blå, biotitt er brun til svart, titanitt har en svak brun farge, mens porer og sprekker er helt svarte. Foto: O. Walderhaug. Fig. I2b. Thin-section micrograph of gneiss from Ølbør III taken with crossed polarizers. Quartz and albite grains are white, grey and black. Muscovite is yellow, pink and blue, biotite is brown to black, sphene is pale brown, pores and fractures are black. Photo: 0 . Walderhaug.
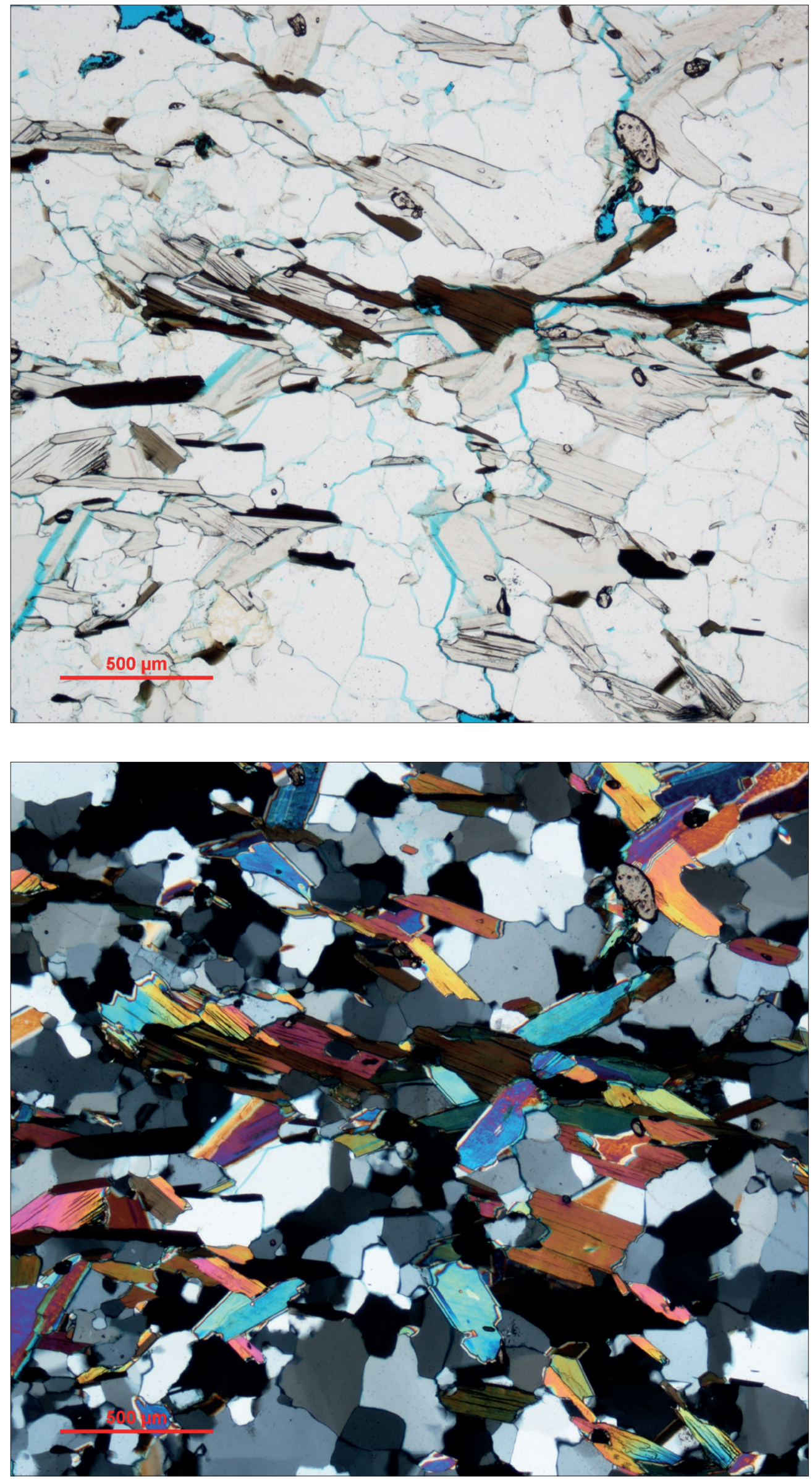


\section{Bergart, geologisk vitring og slitasje}

Ristningene er hugget i en lys grå kvartsrik glimmergneis. Analyse av et tynnslip laget fra en prøve tatt ut $0,7 \mathrm{~m}$ øst for figurene der det har vært sprengt i fjellet, viser at gneisen inneholder $52 \%$ kvarts, $23 \%$ muskovitt, $4 \%$ brun biotitt og $17 \%$ albitt. Rundt en prosent kalifeltspat og titanitt samt spor av zirkon og apatitt ble også påvist. Et par prosent oppløsningsporer med spor av rust er dessuten tilstede. Meget tynne sprekker rundt en del mineralkorn er antagelig et resultat av sprengningsarbeidet (Fig. 12a og 12b).

Kvarts, albitt og kalifeltspat opptrer som en mosaikk av krystaller uten tydelig krystallform og med tverrsnitt 0,05-0,5 mm. Muskovitt og biotitt finnes som plateformete krystaller med tykkelser 0,03-0,3 $\mathrm{mm}$. Muskovittkrystallene danner oftest små grupper av flere krystaller, men definerer i liten grad en tydelig foliasjon og er spredt mere jevnt utover i bergarten enn hva som er tilfelle i gneisene fra Vigdel, «Kråkhaug» og Hellestø. Albittkornene inneholder ofte små inneslutninger av kvarts og glimmer. Titanitt finnes som inntil 0,4 mm lange korn som til dels viser typisk kileformet krystallform, zirkon opptrer som inntil 0,25 cm lange prismatiske krystaller og som mindre avrundete korn, mens apatitt opptrer som avrundete, inntil 0,2 mm store korn uten tydelig krystallform. Titanitt, zirkon og apatitt finnes overveiende som ett og ett korn spredt rundt i bergarten. Oppløsningsporene er 0,05-0,5 mm store. De minste har til dels rombeform, og porene forekommer spredt gjennom tynnslipet.

Laminasjonen i gneisen faller omkring $45^{\circ}$ mot nordnordvest og skjærer den vertikale flaten med ristninger med stor vinkel. Tydelige sprekker mangler på ristningsflaten, men tendenser til svak oppsprekking forekommer ved et par bånd med større mineralkorn orientert parallelt laminasjonen, samt ved en vertikal mineralfylt sprekk.

Fjellets overflate har en del millimeterstore huller og enkelte groper og kanter med relieff på rundt $1 \mathrm{~cm}$, men virker ellers solid. Aktive avskallinger ble ikke sett.

Tynnslipet inneholder rundt $2 \%$ oppløsningsporer, dannet ved oppløsning av kalsitt eller andre svære lettoppløselige karbonatmineraler. Dette kan tilsvare de små hullene som ses med det blotte øye på flaten med ristninger. Andre mineraler er imidlertid ikke oppløste, og kalsittoppløsningen i de ytre deler av fjellet har nok funnet sted før ristningene ble hugget. Oppløsningsporene er isolerte huller og vil dermed ikke føre til avskalling av flak av fjellet. Mikrosprekkene rundt mineralkorn i tynnslipet er antagelig et resultat av sprengningsarbeidet der prøven ble tatt ut, og flaten med ristninger inneholder antagelig få slike sprekker selv om avstanden til utsprengt fjell er så liten at enkelte sprekker kan ha oppstått også ved figurene. Hovedinntrykket fra dette feltet er at flaten med ristninger er i god stand.

\section{Endringer over tid og skader påført av mennesker}

Lokaliteten ble påvist i 1992 og dokumentert etter Riksantikvarens dokumentasjonsskjema i 1998. Da det har gått relativ kort tid siden lokaliteten ble påvist, er det vanskelig å påvise endringer i skadebildet. Bergflaten virker imidlertid å være i god stand, og det er ingen synlige skader. Figurene ble i 1992 malt opp med hvit vannoppløselig maling. Den er nå forsvunnet.
Ingen løse biter eller skader. Ingen bommer. No loose pieces or damage. No air pockets.
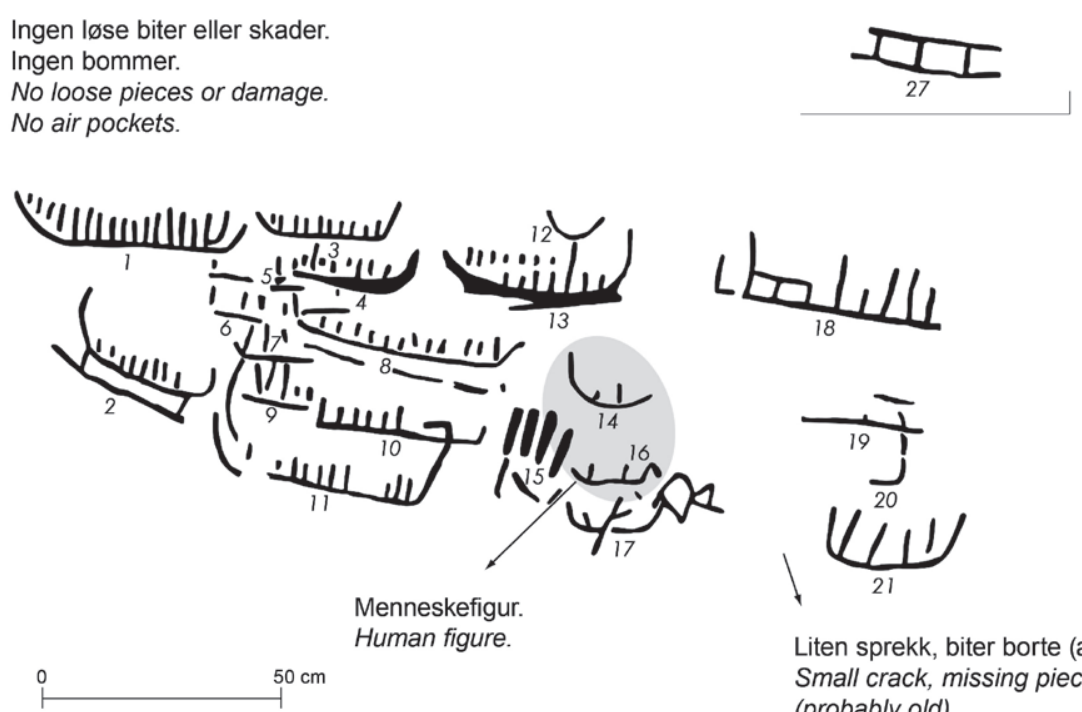

Fig. 13. «Kvernavika», Vigdel (id 34984). Kalkering (E. \& P. Fett, 1941, pl. 39C), med påførte merknader (Bakke, 2009a).

Fig. 13. The rock art site «Kvernavika», Vigdel. Traced by E. \& P. Fett (194I, pl. 39C), with some notes by Bakke (2009a).
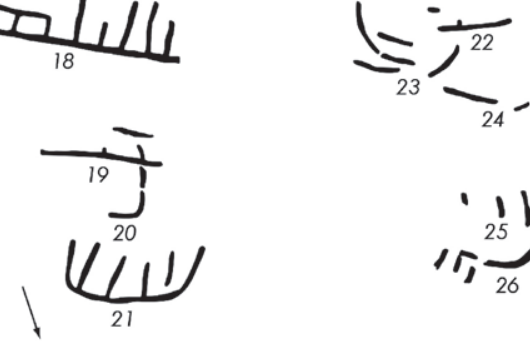

Liten sprekk, biter borte (ant. gammelt). Small crack, missing pieces/fragments (probably old). 


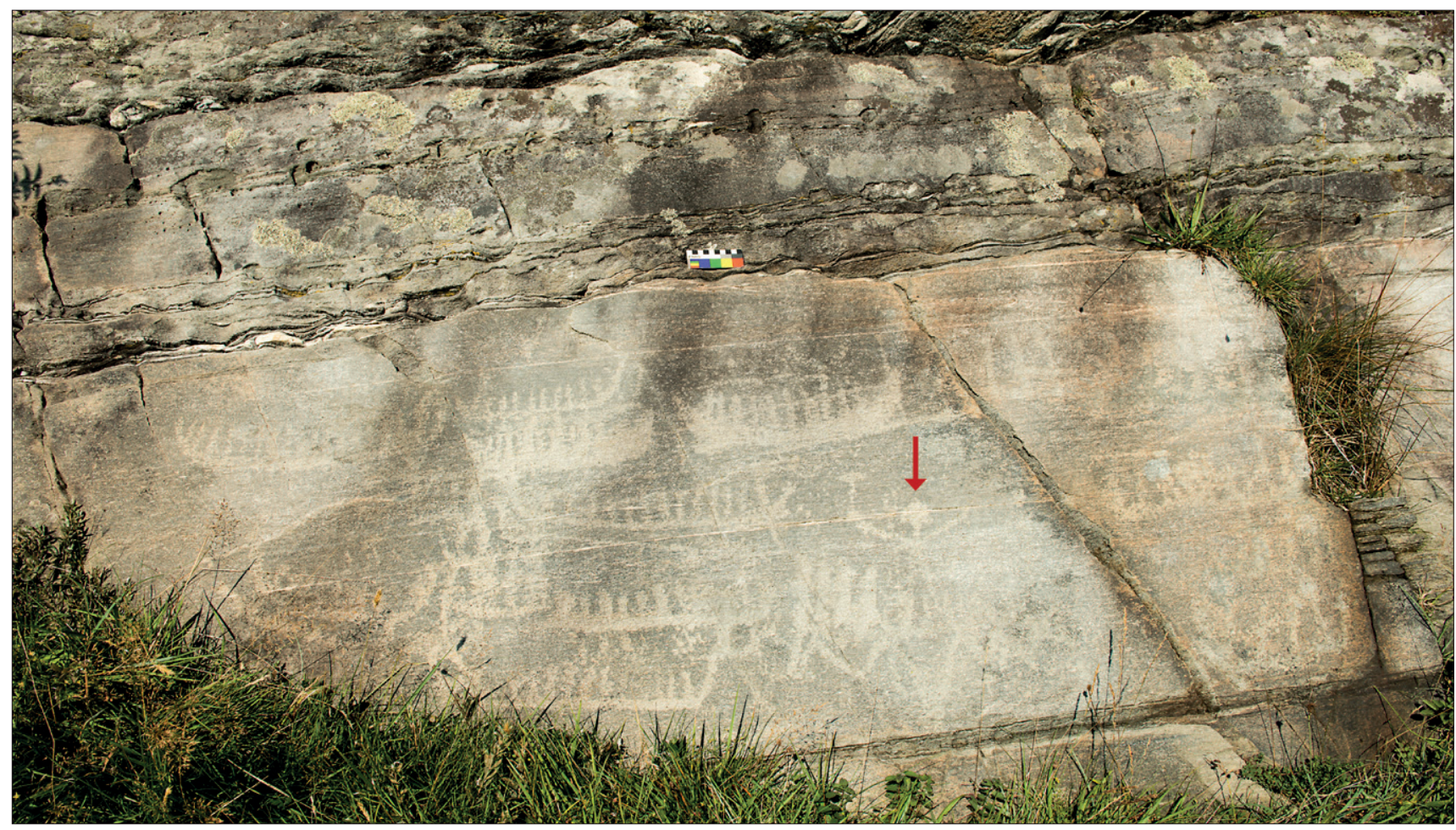

Fig. 14. «Kvernavika», Vigdel. Motiv 14 framstår som menneskefigur med hevede armer og bærer av øks. Foto: A. Pedersen, AM, UiS.

Fig. 14. The rock art site "Kvernavika», Vigdel. Motif no. 14 pictures a man with arms in an upraised position, carrying an axe. Photo: $\AA$. Pedersen, AM, UiS.

\section{I.2 VIGDEL-HELLESTØKOMPLEKSET}

Vigdel, gnr. 22, bnr. 3 - «Kvernavika», Id 34984

Historikk, beliggenhet og presentasjon av lokalitet og figurer

Lokaliteten ble påvist i 1933 av en privatperson, undersøkt samme år og kontrollert i 1937 (E. Fett \& P. Fett, 1941, s. 81). Figurene er hogd inn i en steil østvendt bergvegg ca. $1 \mathrm{~m}$ over bakken og hvor den nederste figuren ligger 7,31 moh. (nivellert av E. Fett \& P. Fett, 1941, s. 81). Videre ligger lokaliteten om lag $400 \mathrm{~m}$ NNV for driftsbygningen på gård nr. 22/2 og om lag $35 \mathrm{~m}$ fra steingjerdet som skiller gnr. 22/3 og 22/2 og som krysser grensa for landskapsvernområdet. E. Fett og P. Fett (1941, s. 82) skilte ut 28 figurer og linjer, hvorav 26 ligger samlet, mens

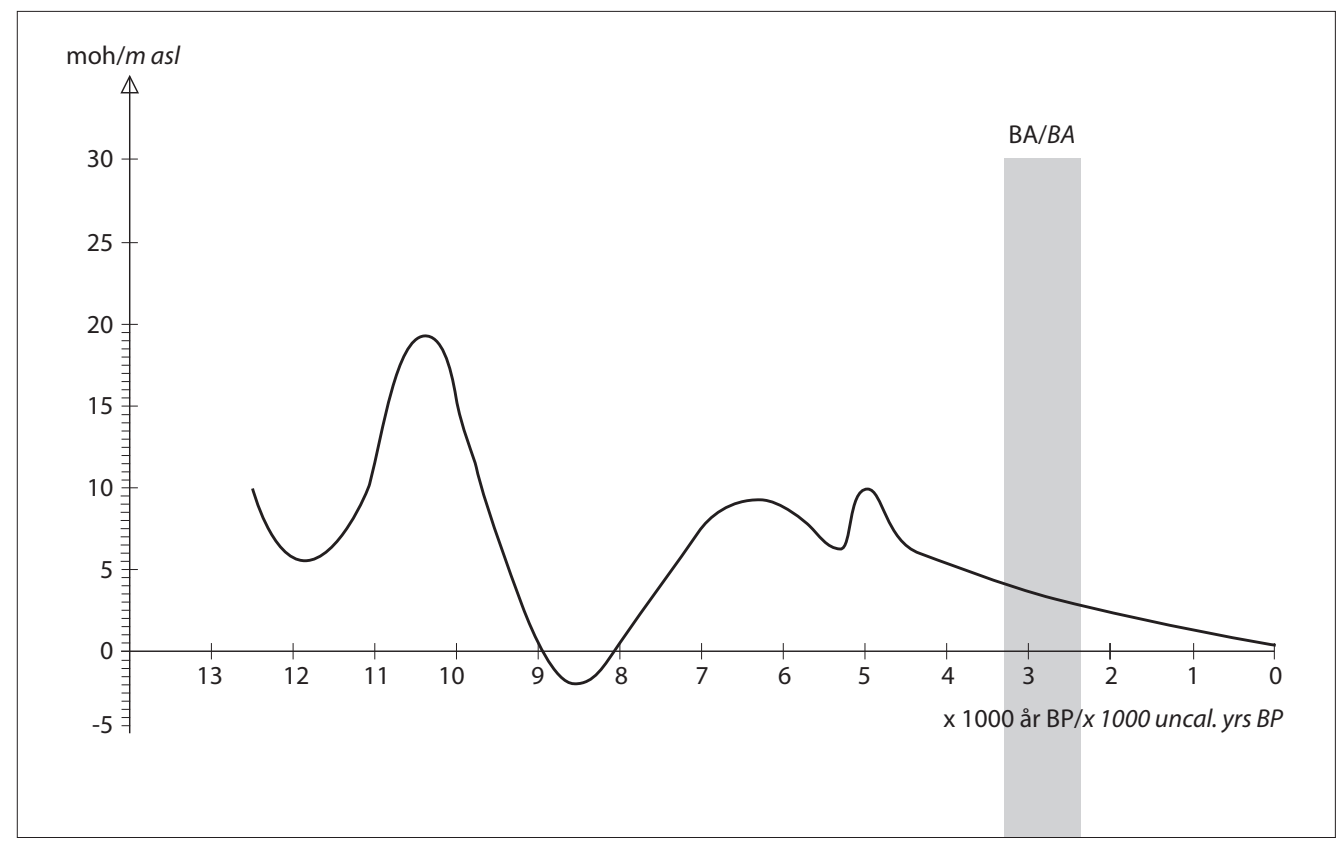

Fig. 15. Beregnet strandlinjekurve for Sola flyplass, gjelder for de aktuelle Bergkunstlokalitetene ved Hellestø og Vigdel (etter Prøsch-Danielsen, 2006; Prøsch-Danielsen \& Selsing, 2009). Havnivå i bronsealder er lagt inn som en gråtone. Fig 15. The sea-level fluctuation curve for the Sola airport site fits for the rock art sites in the Hellesto and Vigdel area (after Prosch-Danielsen, 2006; Prosch-Danielsen \& Selsing, 2009). The sea-level in the Bronze Age is marked grey. 
figur nr. 27 og 28 ligger henholdsvis 1 og 3,5 m sør for $\mathrm{nr}$. 1 (Fig. 13). Som det framgår av Fig. 13 er, med unntak av figur nr. 2 og muligens også nr. 8 og 28, skipene enlinjete. For flere av figurene er det vanskelig å tolke om de er deler av skip eller om det er andre motiv som er forsøkt avbildet. Lokaliteten er også tidligere karakterisert som et felt med særpregete utforminger av skipsfigurene (Sør-Reime, 1984a). Dette gjør det komplisert å datere lokaliteten ut fra skipene. E. og P. Fett (1941, s. 82) definerte figur nr. 28 som ligger 3,5 m fra hovedfeltet til å være et Nag-skip, dvs. et A1-skip. Etter forfatternes mening i så fall noe atypisk, mens figur nr. 2 er et A2-skip (jf. Mandt, 1991, s. 47, for sistnevnte se også Ling 2014, s. 109, nr. 7). Begge dateres til eldre bronsealder, A2-skip kan imidlertid også gå inn i periode IV (Wrigglesworth, 2011, s. 118). De øvrige kan karakteriseres nærmest som B3-skip og gir derfor en datering til yngre bronsealder (jf. Wrigglesworth, 2011, s. 118, se også Kaul, 1998, s. 88, nr. 18). Da skipene er særpregete, er de som nevnt vanskelig å tolke, men det kan se ut som det er eksempler på skip som både seiler mot høyre og venstre.

Figur nr. 12 som kan knyttes til figur nr. 13 er en adorant, mens i figur nr. 1 er det framstilt en mulig adorant. Det er også foretatt en omtolking av figurene nr. 14, nr. 16 og nr. 17; figuren(e) framstår som et menneske med løftede armer som holder ei øks i den ene hånda (se Fig. 14). (Observert av B. Bakke og G. Kjeldsen 2006.) Videre kan kanskje figur nr. 15, som er dypt hogde linjer, tolkes som fire stiliserte menneskefigurer. Da øksemennesket framstår som lite aggressivt, kan scenen tolkes dithen at en sjaman velsigner eller vokter over mennesker. Om enn framstillingen er ulik, kan motivet sammenlignes med scenen på Hedland (id 65851, Fig. 26) der det er avbildet et stilisert menneske med hevet øks over tre eller fire mennesker. Det er bare på disse to lokalitetene slike scener er påvist i Rogaland. Videre er figur nr. 25 et enlinjet skip, mens nr. 26 enten er et enlinjet skip med kun en stavn (med dyrehode), alternativt kan figuren tolkes som et dyr, muligens en hest.

Et annet interessant trekk ved lokaliteten er at mange av figurene er prikkhugde dvs. at det hovedsakelig ikke er «tale om en sammenhengende linje, men enkeltstående huggmerker på rad» (E. Fett \& P. Fett 1941, s. 82).

\section{Strandlinjestudier}

I området Ølbør/Vigdel kan vi ta utgangspunkt i strandlinjekurven for Sola flyplass (Fig. 15) når vi skal rekonstruere landskapet ved inngangen til eldre bronsealder (Prøsch-Danielsen, 2006). Bergkunstlokaliteten på Vigdel ligger innenfor Kvernavik. Figurene er hogd på en bergflate som vender inn mot en oppdyrket mark, og lokaliteten er dermed vendt bort fra sjøen, et trekk som er uvanlig for bergkunstlokaliteter i Rogaland. Det løper ei trang fjellkløft mellom sjøen i Kvernavik og den oppdyrkede marken i dag (Fig. 16). Ristningsflaten kan således fortone seg ganske uforståelig sett i forhold til dagens strandlinje. Under den siste Tapes-transgresjonstoppen som fant sted om lag 4000 f.Kr. sto havnivået $10 \mathrm{~m}$ høyere enn i dag. Det betyr at havvannet i Kvernavik gikk videre inn gjennom kløfta og innover terrenget i øst, og det oppsto ei god lun havbukt. Kløfta fungerte som ei trakt, men var likevel videre enn det man får inntrykk av i dag. I neolitikum var det kun denne bukta og ei bukt lenger sør ved Båane/Kråke ved Hellestø som kunne gi ei lun

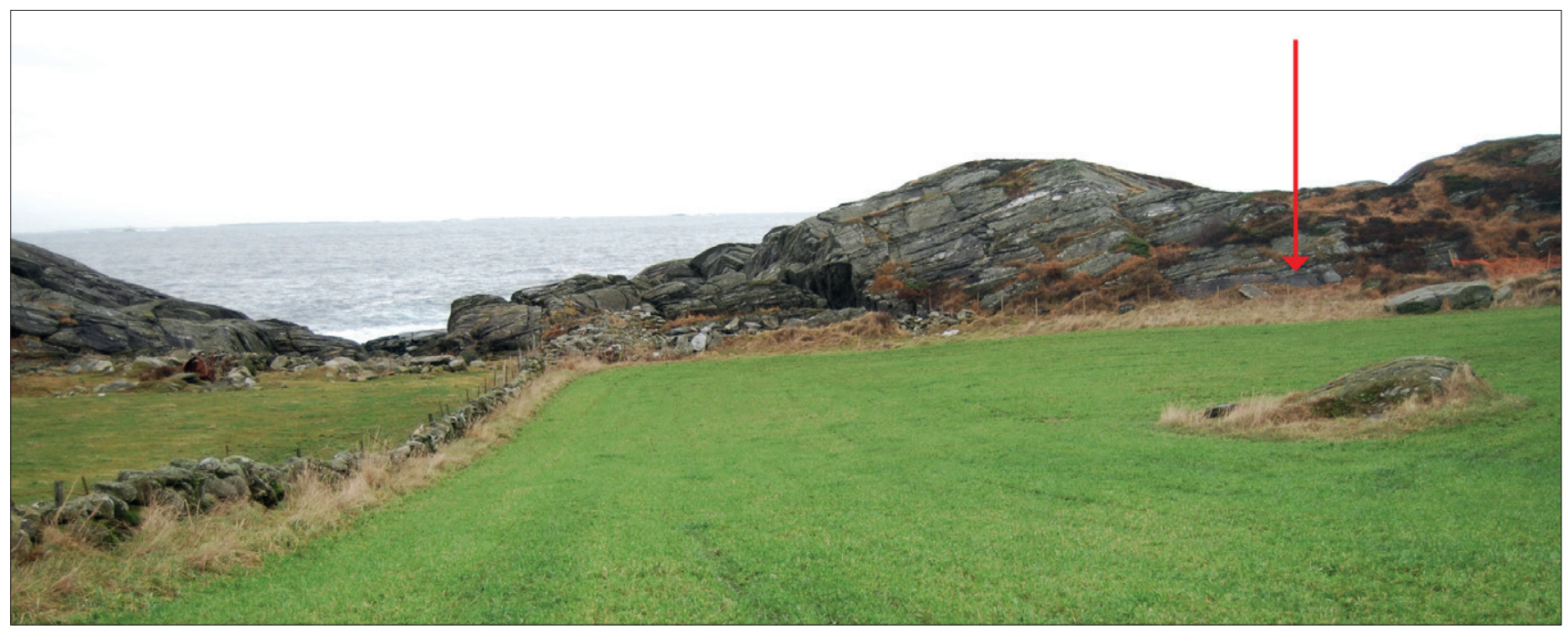

Fig. 16. Bergkunstfeltet i Kvernavika ligger vendt mot land. Ved inngangen til eldre bronsealder sto imidlertid havnivå høyere, og ei havbukt førte inn til lokaliteten. Foto: L. Prøsch-Danielsen, AM, UiS.

Fig. 16. The rock art site at Kvernavika faces inland. However, in the Early Bronze Age the sea-level was higher and created a small bay in front of the site. Photo: L. Prøsch-Danielsen, AM, UiS. 


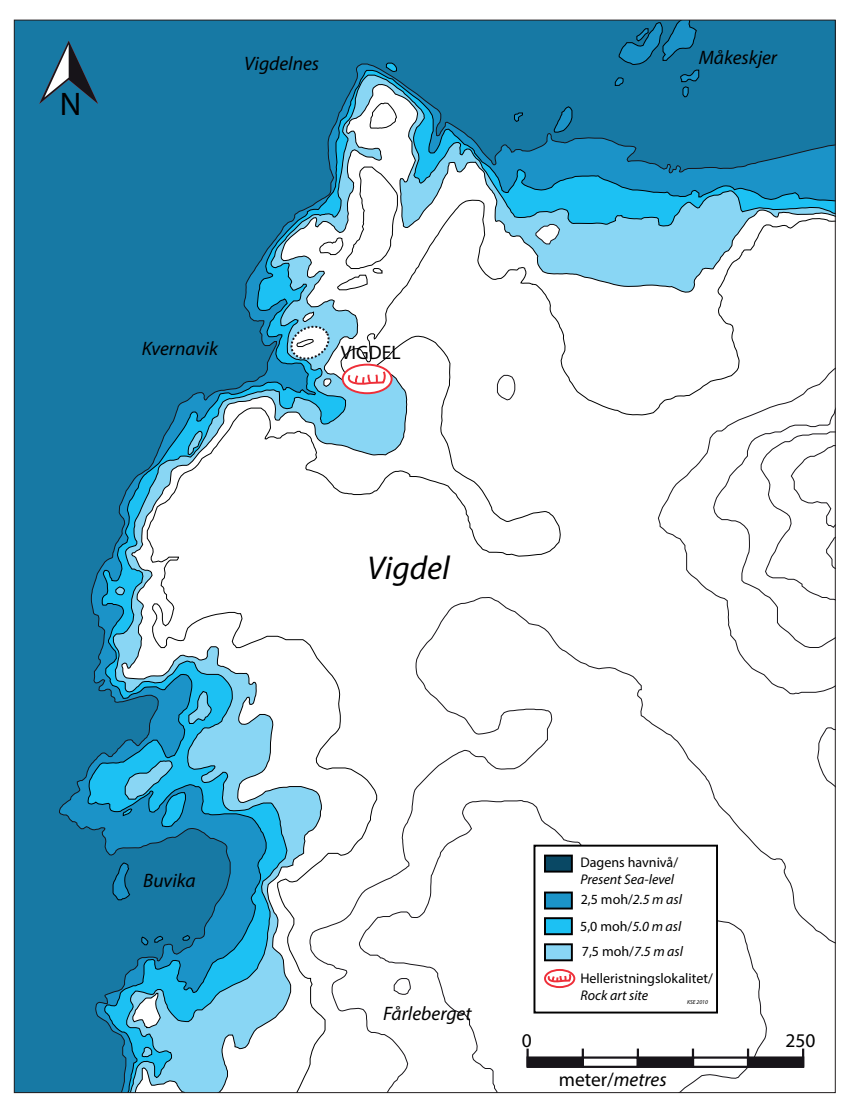

Fig. 17. Lokalisering av bergkunstfeltet $\mathrm{i}$ «Kvernavika» på Vigdel med nedre grense på 7,31 m over dagens havnivå sett i forhold til havnivå $\mathrm{i}$ ulike perioder. Havnivået ved inngangen til eldre bronsealder periode I (I700 f.Kr.) sto omlag $5 \mathrm{~m}$ høyere enn i dag, og ved inngangen til yngre bronsealder periode IV (II00 f.Kr.) sto havnivået om lag 2,5 m høyere enn i dag. Kart: L. Prøsch-Danielsen \& Krister Eilertsen, AM, UiS.

Fig. 17. The localization of the rock art site at "Kvernavika" Vigdel (with lower level $7.3 \mathrm{Im}$ above present sea-level) seen in relation to a changing sea-level in prehistoric time. The sea-level in BA period $I$ (I700 BC) was close to the $5 \mathrm{~m}$ niveau. Around BA period IV (II00 BC) it had decreased to app. $2.5 \mathrm{~m}$ asl. Drawing: L. ProschDanielsen \& Krister Eilertsen, AM, UiS.

havn for opptrekk av båter på strekningen mellom Ølbør og Byberg/Selestranda. Nedre grense for bergkunstlokaliteten er nivellert til 7,31 m over dagens havnivå (E. Fett \& P. Fett, 1941, s. 81). Ved inngangen til eldre bronsealder (bronsealder periode I) omkring 3400 radiokarbonår BP (1700 f.Kr.) sto havnivået (dvs. stormflo) omkring $5 \mathrm{~m}$ høyere enn i dag (Fig. 17). Havbukta er på det tidspunktet sterkt redusert, men strakte seg likevel innenfor kløfta. Ved inngangen til yngre bronsealder (bronsealder periode IV) omkring 2900 radiokarbonår BP, dvs. 1100 f.Kr. sto havnivået bare 2,5 m høyere enn i dag, og det ble umulig å forsere kløfta. Ett til to av skipene kan muligens dateres til eldre bronsealder. Dersom dateringen medfører riktighet, ble lokaliteten påbegynt da det fortsatt var ei lita bukt inn mot lokaliteten, et sted der båter kunne bli trukket opp. I yngre bronsealder var det imidlertid ingen direkte tilknytning til sjøen.

\section{Bergart, geologisk vitring og slitasje}

Bergarten som ristningene er hugget $i$ er en grå planlaminert kvartsrik glimmergneis. Mikroskopering av et tynnslip laget fra et ca. $3 \mathrm{~cm}$ stort løst stykke av bergarten fra et jordfylt hakk $25 \mathrm{~cm}$ skrått opp til høyre for figur nr. 21, gir et kvartsinnhold på $44 \%$ og et muskovittinnhold på $18 \%$. I tillegg opptrer $26 \%$ albitt, $4 \%$ brun biotitt, samt spor av kloritt, zirkon, apatitt, grafitt og opake jern-titanoksider. Prøven inneholder også $4 \%$ porer dannet ved oppløsning av mineraler, antagelig karbonat, og $3 \%$ rust som for det meste delvis fyller oppløsningsporer. Prøven inneholder også en del åpne sprekker parallelt med laminasjonen og rundt mange av de enkelte mineralkornene. Disse sprekkene er antagelig i liten grad tilstede i det langt fastere fjellet der ristningene er hugget, og sprekkene er derfor holdt utenfor da prøvens sammensetning ble bestemt (Fig. 18a og 18b).

Kvarts og albitt opptrer som en mosaikk av ekvidimensjonale til noe avlange krystaller uten tydelig krystallform og med tverrsnitt overveiende mellom 0,1 og $1 \mathrm{~mm}$. En svak tendens til orientering av lengste tverrsnitt for kvarts- og albittkrystallene langs foliasjonen er tilstede, men foliasjonen er først og fremst definert av parallellorienterte $0,01-0,1 \mathrm{~mm}$ tykke flakformige krystaller av muskovitt, biotitt og kloritt. Muskovitt og biotitt har en tendens til å være konsentrert i inntil 0,3 mm tykke lameller, mens de mellomliggende kvarts- og albittdominerte lamellene har tykkelser som kan nå opp i $1 \mathrm{~mm}$. Albittkornene inneholder ofte små inneslutninger av glimmer og kvarts. Apatitt finnes som spredte 0,1-0,2 $\mathrm{mm}$ store korn uten tydelig krystallform, mens grafitt danner inntil 0,15 $\mathrm{mm}$ lange oftest plateformige og noe avrundete krystaller. Jern-titanoksidene opptrer som spredte velformete krystaller med størrelse mindre enn $0,5 \mathrm{~mm}$. Zirkon forekommer som sjeldne inntil 0,2 mm lange korn som dels har en prismatisk krystallform. Rust finnes først og fremst på veggene i oppløsningsporene. Oppløsningsporene i tynnslipet varierer i størrelse fra under 0,1 $\mathrm{mm}$ til 1-2 $\mathrm{mm}$.

Laminasjonen i gneisen faller $45^{\circ}$ mot nordvest og skjærer dermed flaten med figurene nokså vinkelrett. Sprekker parallelt med laminasjonen forekommer, og fjellet gjennomsettes også av noen få steiltstående sprekker orientert omtrent øst-vest. Sprekkene er eldre enn ristningene, og noen figurer er hugget over mindre sprekker.

Fjellets overflate der figurene er hugget er solid og temmelig plan og glatt, men med en del opptil et par mm store huller som kan være oppløsningsporer etter karbonatmineraler. Flaten med figurer er uten avskallinger og bompartier, og huggemerker er ofte lett synlige. 


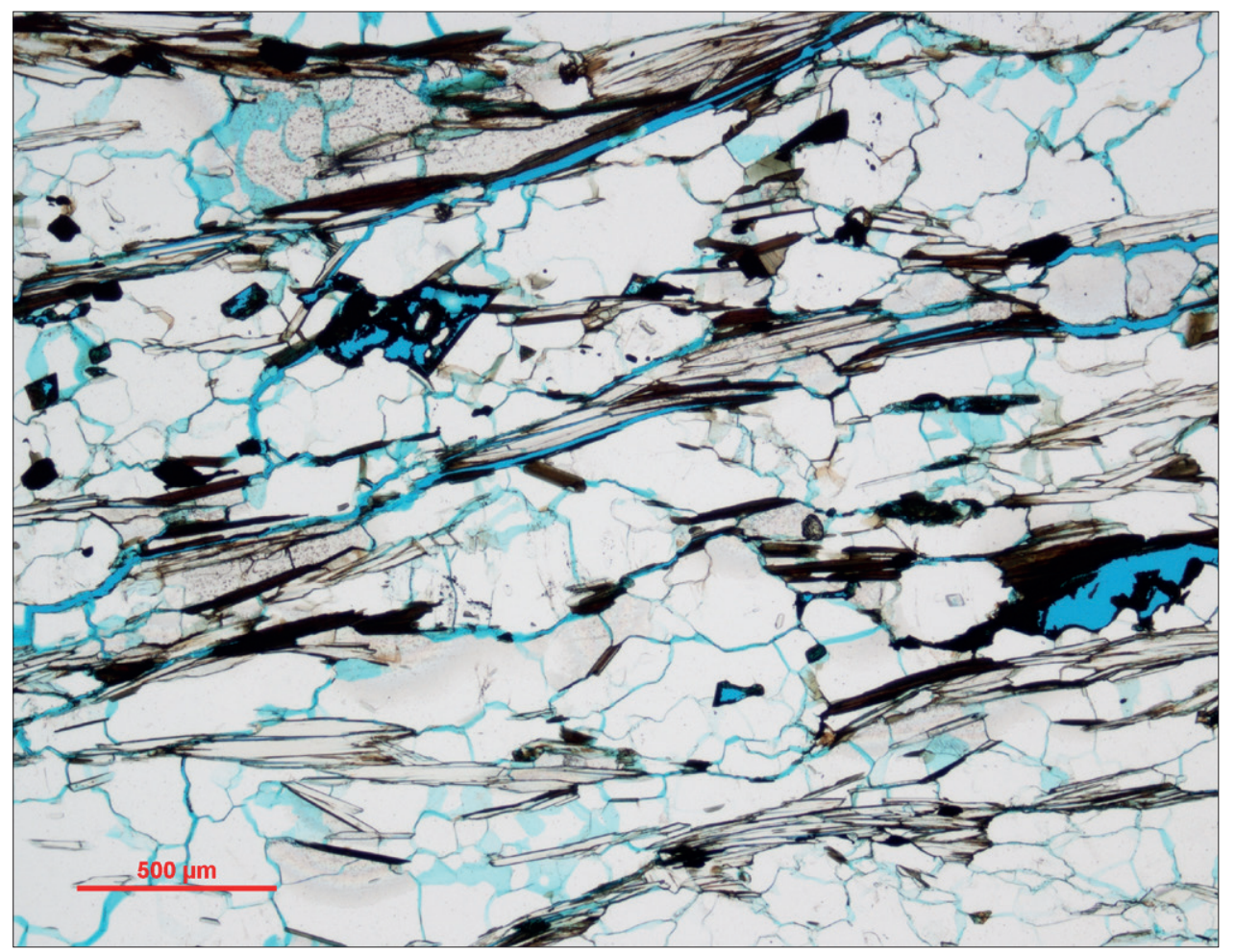

Fig. 18a. Tynnslipbilde av glimmergneis fra Kvernavika tatt med planpolarisert lys. Hvite områder er kvarts og albitt. Parallellorienterte avlange hvite til grålige korn med kløv er muskovitt, mørkebrune og svarte avlange korn er biotitt. Oppløsningsporer etter karbonat samt sprekker er blå. Oppløsningsporenes vegger er dekket av rust med svart farge. Foto: $\mathrm{O}$. Walderhaug.

Fig. 18a. Thin-section micrograph of gneiss from Kvernavika taken in plane-polarized light. White areas are quartz and albite. Parallel white to pale grey elongate grains with distinct cleavage are muscovite, dark brown and black elongate grains are biotite. Fractures and dissolution pores after carbonate are blue. The walls of the dissolution pores are covered by rust with a black colour. Photo: O. Walderhaug.

En del 0,01-0,05 mm tykke sprekker parallelt med laminasjonen ses i tynnslipet, og enda tynnere sprekker opptrer langs en del krystallgrenser. Prøven det ble laget tynnslip av var imidlertid langt mer vitret og skjør enn flaten der figurene er hugget, og mange av sprekkene kan også være utvidet under tynnslippreparering. Det virker derfor lite sannsynlig at selve flaten med ristninger har samme grad av oppsprekking. Tvert imot virker området med ristninger solid og med få sprekker av denne typen. $7 \%$ porer dannet ved oppløsning av karbonat forekommer også i tynnslipet, og rustutfellinger fyller nesten halvparten av disse porene. Relativt lettoppløselige mineraler som apatitt, biotitt og kloritt viser imidlertid ingen tegn til oppløsning. Det er dermed sannsynlig at svært

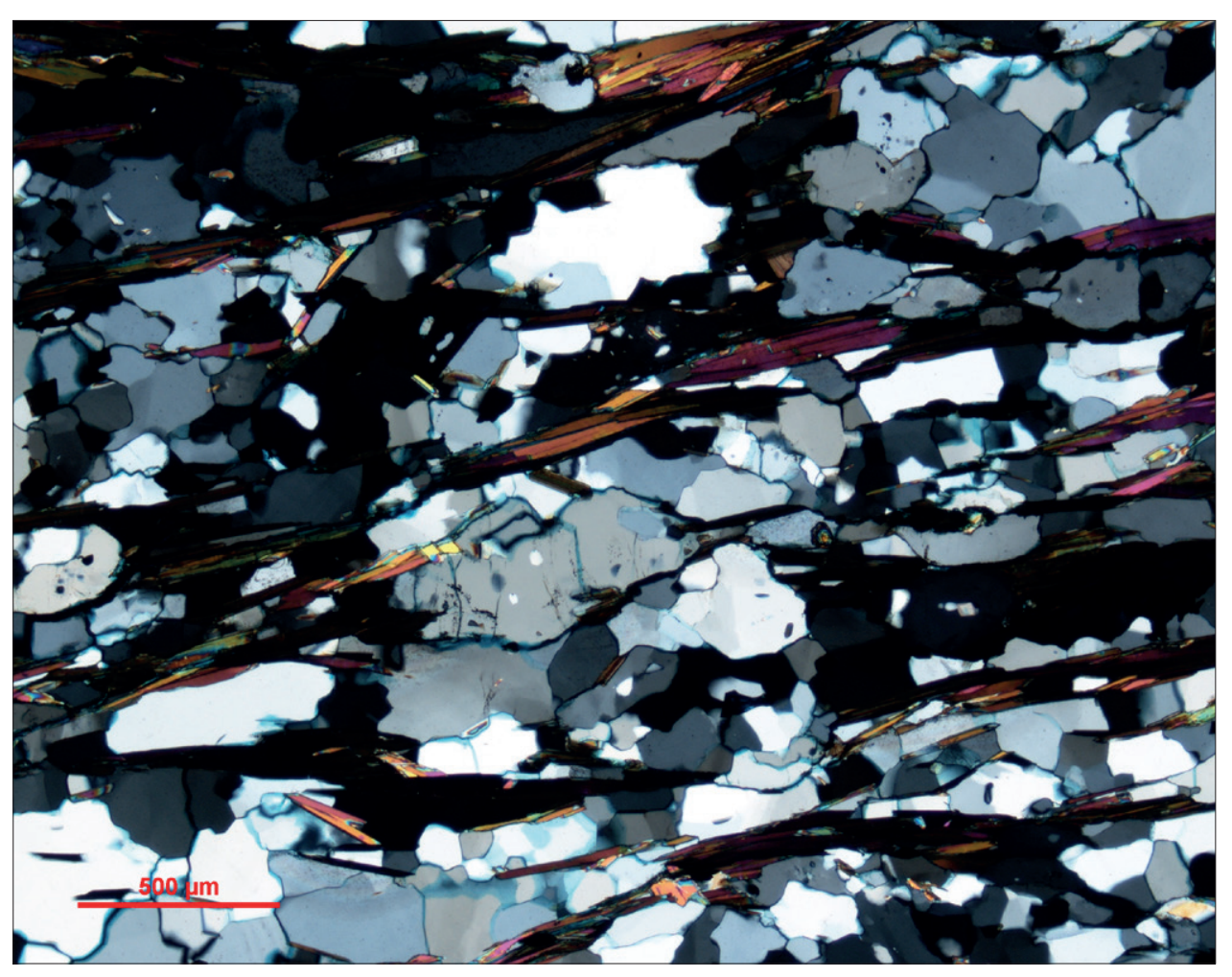

Fig. 18b. Tynnslipbilde av glimmergneis fra Kvernavika tatt med kryssede polarisasjonsfiltre. Kvarts og albitt er hvit, grå og svart. Muskovitt er rosa og gul. Biotitt, rust og porer framstår som svarte. Foto: $\mathrm{O}$. Walderhaug.

Fig. 18b. Thin-section micrograph of gneiss from Kvernavika taken with crossed polarizers. Quartz and albite grains are white, grey and black. Muscovite is pink and yellow. Biotite, rust, fractures and pores are black. Photo: $O$. Walderhaug. 


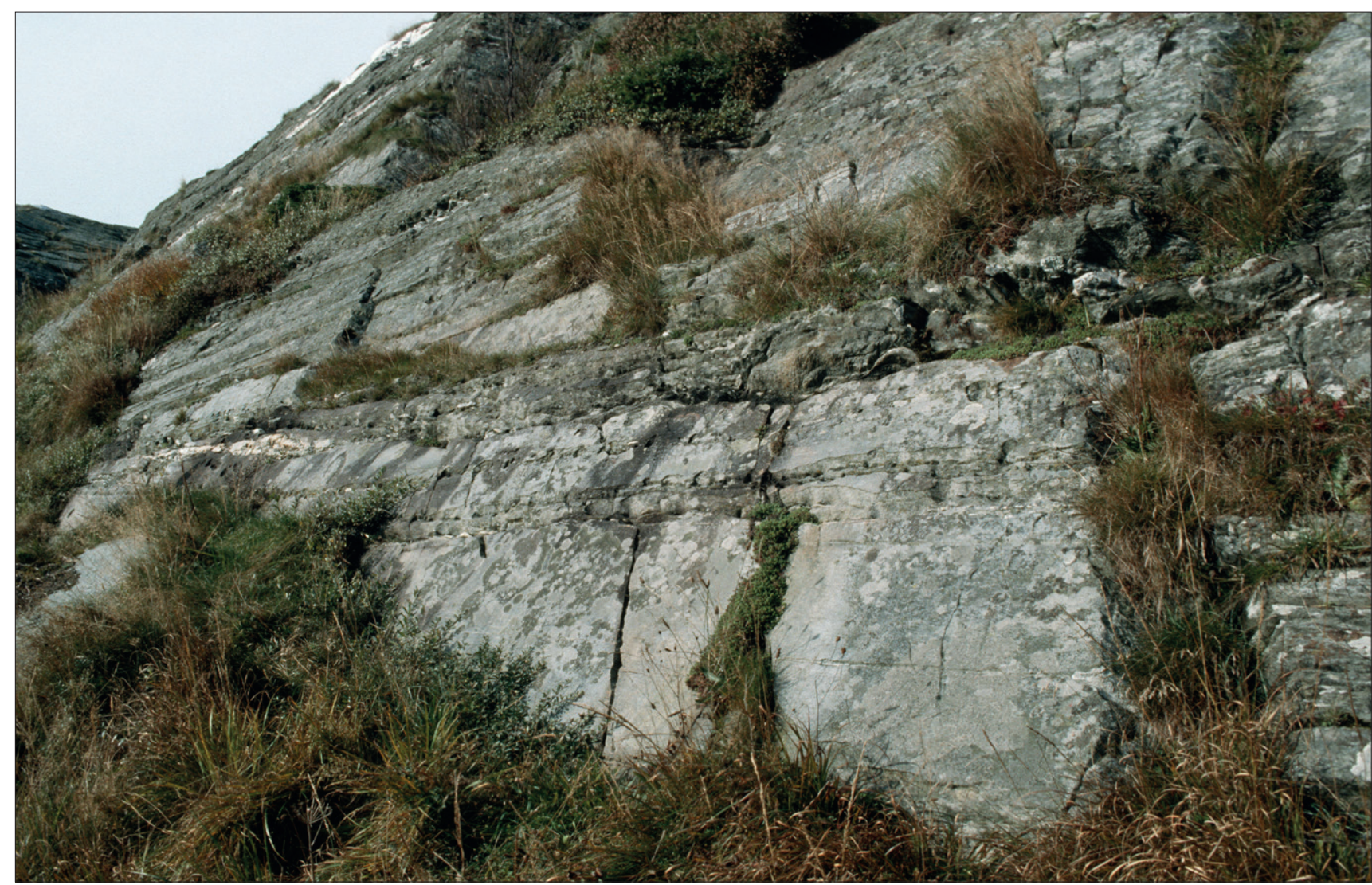

Fig. 19. Lokaliteten Kvernavika før skjøtsel. Foto: Å. Pedersen, AM, UiS.

Fig. 19. The locality Kvernavika prior to management. Photo: $\AA$. Pedersen, AM, UiS.

lettoppløselig karbonat er det eneste mineralet i gneisen som har vært utsatt for oppløsning, og denne karbonatoppløsningen har antagelig overveiende funnet sted før ristningene ble hugget. Porene etter karbonatoppløsning er også synlige med det blotte øyet på bergflaten med ristninger, men da disse porene ligger isolert i uforvitret fjell som overveiende består av kvarts, albitt og muskovitt, representerer de neppe noen stor fare for fjellet. Som nevnt over ble det ikke sett avskallinger eller bompartier.

\section{Endring over tid og skader påført av mennesker}

E. Fett og P. Fett (1941, s. 82) skriver at ristningene er «hugget helt nede ved foten av berget, på et sted der overflaten er temmelig jevn og glatt». «Ristningsflaten er en spalteflate, men lagdelingen i berget går på tvers av denne». De kommenterer videre at selv om linjene er grunne (prikkhugget) og ses best i godt sidelys, er de likevel forholdsvis klare pga. tydelig hugging. Sømme Dahl (1985) skriver at den kvartsrike glimmergneisen varierer; partiet som figurene er hugd i er relativt fattig på glimmer og rik på kvarts og feltspat. Over ristningene er det imidlertid bånd som er langt mer forvitrete og glimmerrike. Ved skipene er der en plan, hard overflate, men en god del $\mathrm{mm}$-store forvitringshull er allerede utviklet innimellom kvartsen og feltspaten. Like over helleristningsfeltet i fast fjell er en sprekk som er kraftig erodert. Sprekken er over $3 \mathrm{~m}$ lang, opptil $10 \mathrm{~cm}$ dyp og $15 \mathrm{~cm}$ bred. Sprekken over denne er dobbelt så lang med samme bredde og dybde. Sømme Dahl konkluderer imidlertid med at ristningene ikke er spesielt truet. Hun påpeker også at det ut fra eldre fotografier ikke er mulig å se om små sprekker eller groper har forandret seg. De store sprekkene (dvs. Sømme Dahl, 1985) er imidlertid like dem man ser i dag. Da lokalitetene igjen ble dokumentert i 1998 og 1999 ble fjellet oppfattet som svært forvitret. Figurene var vanskelige å se pga. sterk lav- og algevekst, noe det porøse berget og sigevannet ga god grobunn for (Bakkevig, 2000). Seinere har lokaliteten blitt påpenslet etanol så å si årlig (Fig. 19 sml. Fig. 14). Da lokaliteten igjen ble skadekartlagt i 2009, ble det konkludert med at lokaliteten var i god stand, ingen løse biter eller skader og ingen «bommer» ble påvist (Bakke, 2009a).

Ny geologisk undersøkelse i 2009 konkluderte, som nevnt ovenfor, at flaten med ristninger inneholder en del porer etter karbonatoppløsning, men er solid og uten avskallinger eller sprekker som representerer noen stor fare for ristningene.

Lokaliteten ble krittet opp i forbindelse med kalkeringen i 1933, men den er heldigvis aldri blitt malt opp da dette ville ha skjult prikkhoggingen. 


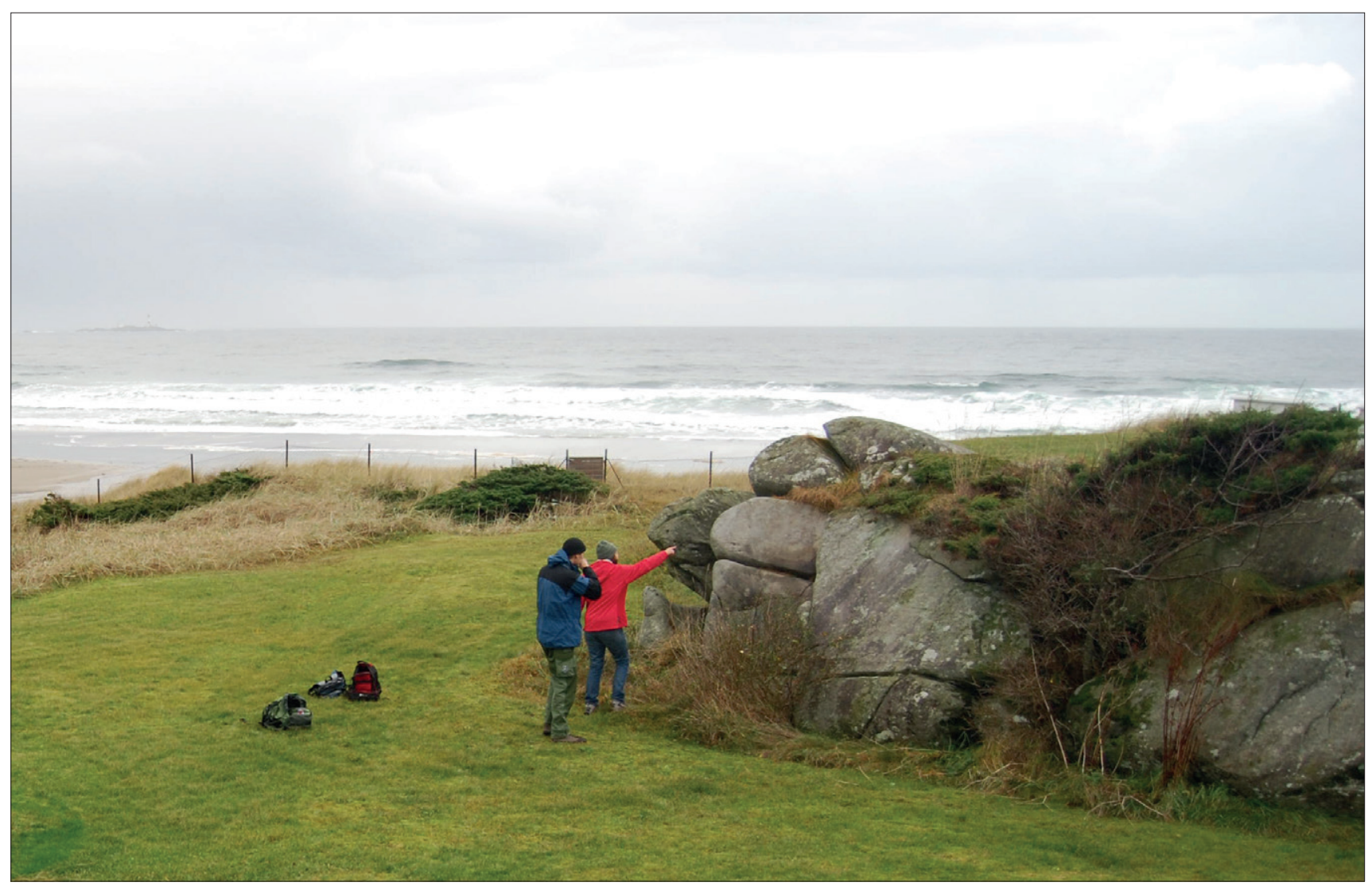

Fig. 20. Hellestø, lokaliteten med utsikt mot havet. Foto: L. Prøsch-Danielsen, AM, UiS.

Fig. 20. The rock art site Hellestø. View towards the North Sea in the west. Photo: L. Prøsch-Danielsen, AM, UiS.

\section{Hellestø gnr. 23, bnr. 14, Id 44551}

Historikk, beliggenhet og presentasjon av lokalitet og figurer

Ifølge E. Fett og P. Fett (1941, s. 82) ble lokaliteten påvist av Petersen i 1925, og den ble omtalt i Stavanger Aftenblad 22. september samme år. Lokaliteten ligger om lag $110 \mathrm{~m}$ øst for sjøen, ca. $70 \mathrm{~m} \mathrm{SSV}$ for feriehjemmet på gnr. 23/14 og 5-6 $\mathrm{m}$ sør for hytte på eiendommen. Ristningene ligger på en knaus som på sørsiden har en flate som er vendt mot ØSØ (Fig. 20). I 1933 ble lokaliteten undersøkt og kalkert av E. Fett og P. Fett som skriver at nedre del (om lag $1 \mathrm{~m}$ ) var dekket av sand. I følge kalkeringen til E. Fett og P. Fett er det påvist 26 figurer, av disse er det en solfigur, skip med og uten mannskapsstreker samt flere parallelle og enkle linjer samt streker som kan være mannskapsstreker. En naturlig sprekk skiller nr. 1-6 fra nr. 7-26 (Fig. 21). Etter registreringen på 1930-tallet ble lokaliteten så å si glemt. I 1968 skriver Johnsen (1968a, s. 167) at lokaliteten er nedgravd foreløpig og består av et «dusin skip, linjer og et hjulkors (?)». I Johnsens magisteravhandling (1974) er det kun henvist til E. Fett og P. Fett (1941). I 1982 ble stedet befart, og det tok lang tid før lokaliteten ble gjenfunnet pga. at fjellet var dekket av kratt. Ved å føre dette til sides ble det konstatert at en var på rett sted, men at bare de øvre figurene var synlige (Vinsrygg, 1982a). Sømme
Dahl (1985) skriver at det vokser en stor tornebusk like opptil berget, og at hun ikke var i stand til å se ristningene da de var helt overgrodd av grønske. Ved registrering for Økonomisk kartverk i 1991 (Trøim og Henriksen, 1991b) var det heller ikke mulig å se ristningene pga. dekkende vegetasjon og sandflukt. I 1992 ble vegetasjonen fjernet i forbindelse med oppmaling, og en del av ristningene ble synlige. Det viste seg da at deler av lokaliteten var dekket av flygesand, dvs. figurene under 10, 13 og 21, noe som også er situasjonen i dag. I forbindelse med dette arbeidet ble det i en dyp sprekk som går horisontalt i fjellet, og ca. $70 \mathrm{~cm}$ ovenfor den øverste ristningen, funnet sju små knakkesteiner kilt innerst i sprekken (S11254, Fig. 22). Dette er små strandsteiner av granittisk bergart som alle har tydelig knusespor langs sidene. Steinene må ha ligget der lenge da enkelte var dekket med lav. Om de kan knyttes til huggingen av ristningene eller plassert der seinere er vanskelig å avgjøre (Hernæs, 1992b).

I de seinere årene er det påvist én figur ovenfor øverste ristning (nr. 1 hos Fett \& Fett, 1941, pl. 39D), hjulkors, skip samt solholder på figur nr. 17 og dessuten en enlinjet båt med solholder mellom figur nr. 17 og nr. 19 (se Fig. 21 og 23). Det er med andre ord nå påvist 31 figurer på lokaliteten. I 1993 oppdaget Eide (1993) mulige ristninger som ble tolket som henholdsvis slangefigur og en som likner på 
Fig. 2I. Hellestø (id 4455I), kalkering (E. \& P. Fett, 194I, pl. 39D) med påførte merknader (Bakke 2009a) samt nye figurer (stiplete linjer).

Fig. 2l. The rock art site at Hellestø. Traced by E. \& P. Fett (194I, pl. 39D) with notes from Bakke (2009a). New figures are added (stippled lines).

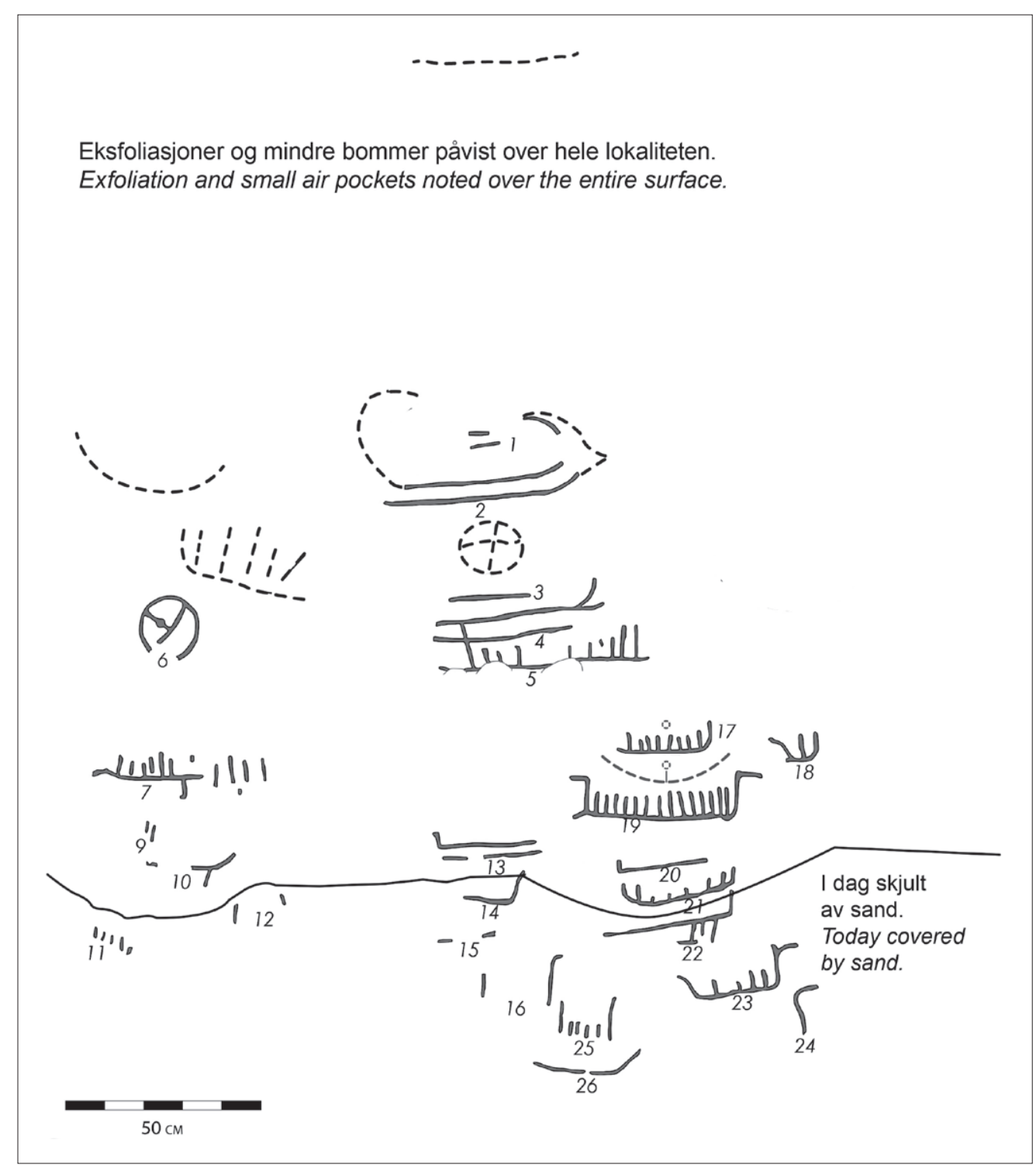

Eksfoliasjoner og mindre bommer påvist over hele lokaliteten.

Exfoliation and small air pockets noted over the entire surface.

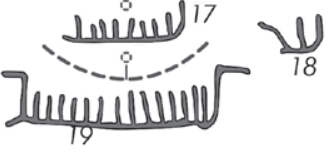
$16 \int_{\log _{25} 1}$

26

olholder, en til to har hestehoder i stavnen (nr. 23 og nr. 19?), det er påvist to hjulkors, og dessuten er figurene prikkhogde dvs. ikke en sammenhengende linje, men enkeltstående huggmerker på rad, noe som sjeldent forekommer i Rogaland. Lik lokaliteten på Vigdel der figurene også er prikkhogd, er ristningene vendt fra sjøen.

\section{Strandlinjestudier}

Bergkunstfeltet ved Hellestø ligger akkurat på overgangen mellom sandstranda og Ølbør/Vigdel-neset der berggrunnen kommer fram i dagen. For å kunne relatere kunnskapen om havnivåendringer til bergkunstfeltene i dette området må en ta utgangspunkt i en kjent strandlinjekurve fra området ved Sola flyplass (Fig. 15) (PrøschDanielsen, 2006). I dag er de nederste motivene i bergkunstfeltet skjult av flyvesand. Nedre grense for motivene er nivellert til 5,33 m over havet, øvre grense til 6,62 m over havet (E. Fett \& P. Fett, 1941, s. 82). Ved inngangen til 


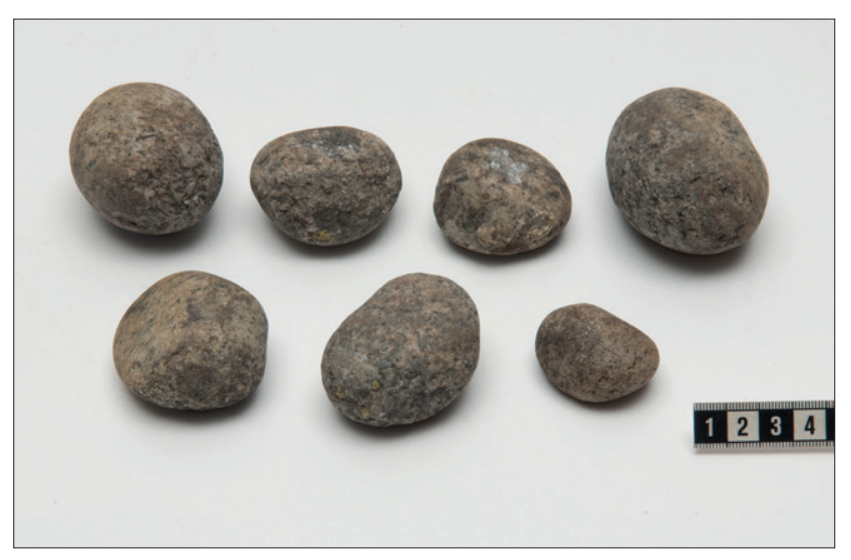

Fig. 22. Sju knakkesteiner (SII254) ble funnet i en dyp sprekk ved bergkunstfeltet på Hellestø. Foto: T. Tveit, AM, UiS.

Fig. 22. Seven hammerstones (SII254) were found in a deep fissure at the rock art site Hellestø. Photo: T. Tveit, AM, UiS.

eldre bronsealder sto strandlinjen $5 \mathrm{~m}$ høyere enn i dag. Ristningsfeltet kan således ha ligget like i strandsonen ved inngangen til bronsealder, mens i yngre bronsealder er den direkte kontakten brutt. Som det framgår ovenfor dateres lokaliteten til yngre bronsealder, men den kan være påbegynt i eldre bronsealder.

\section{Bergart, geologisk vitring og slitasje}

Figurene er hugget i en lys planlaminert kvartsrik glimmergneis. Analyse av et tynnslip laget fra en prøve, tatt ut $22 \mathrm{~m}$ NNØ for feltet, gir et kvartsinnhold på $56 \%$, et muskovittinnhold på $14 \%$ samt $9 \%$ brun biotitt. I tillegg opptrer $18 \%$ albitt, $1 \%$ epidot, $1 \%$ kalsitt, samt spor av kloritt, zirkon, turmalin, apatitt, titanitt og grafitt. Prøven inneholder også $0,3 \%$ porer dannet ved oppløsning av kalsitt. Prøven inneholder mikrosprekker rundt mange av de enkelte mineralkornene, antagelig pga. bruk av slegge eller dynamitt der prøven ble tatt ut. Disse sprekkene er antagelig i liten grad til stede der ristningene er hugget, og sprekkene er derfor holdt utenfor da prøvens sammensetning ble bestemt.

Kvarts og albitt opptrer som en mosaikk av ekvidimensjonale til noe avlange krystaller uten tydelig krystallform og med tverrsnitt overveiende mellom 0,05 og 0,5 mm. En svak tendens til orientering av lengste tverrsnitt for kvarts- og albittkrystallene langs foliasjonen er tilstede, men foliasjonen er først og fremst definert av parallellorienterte $0,01-0,1 \mathrm{~mm}$ tykke flakformige krystaller av muskovitt, biotitt og kloritt. Muskovitt og biotitt har i deler av tynnslipet en svak tendens til å være konsentrert i inntil $0,2 \mathrm{~mm}$ tykke lameller, men er for det meste nokså jevnt fordelt gjennom gneisen. Albittkornene inneholder ofte små inneslutninger av glimmer og kvarts. Kalsitt opptrer som opptil 1,5 mm store og ofte noe avlange flekker, med lengste tverrsnitt parallelt med foliasjonen, og med en tendens til å være anriket i visse lameller. Titanitt finnes som spredte enkeltkrystaller med størrelse inntil $0,3 \mathrm{~mm}$ og til dels med den kileformete krystallformen som er typisk for dette mineralet. Epidot opptrer også som spredte korn med omtrent samme størrelser som for titanitt, mens epidotkornene er vanligvis avrundete og uten gjenkjennelig

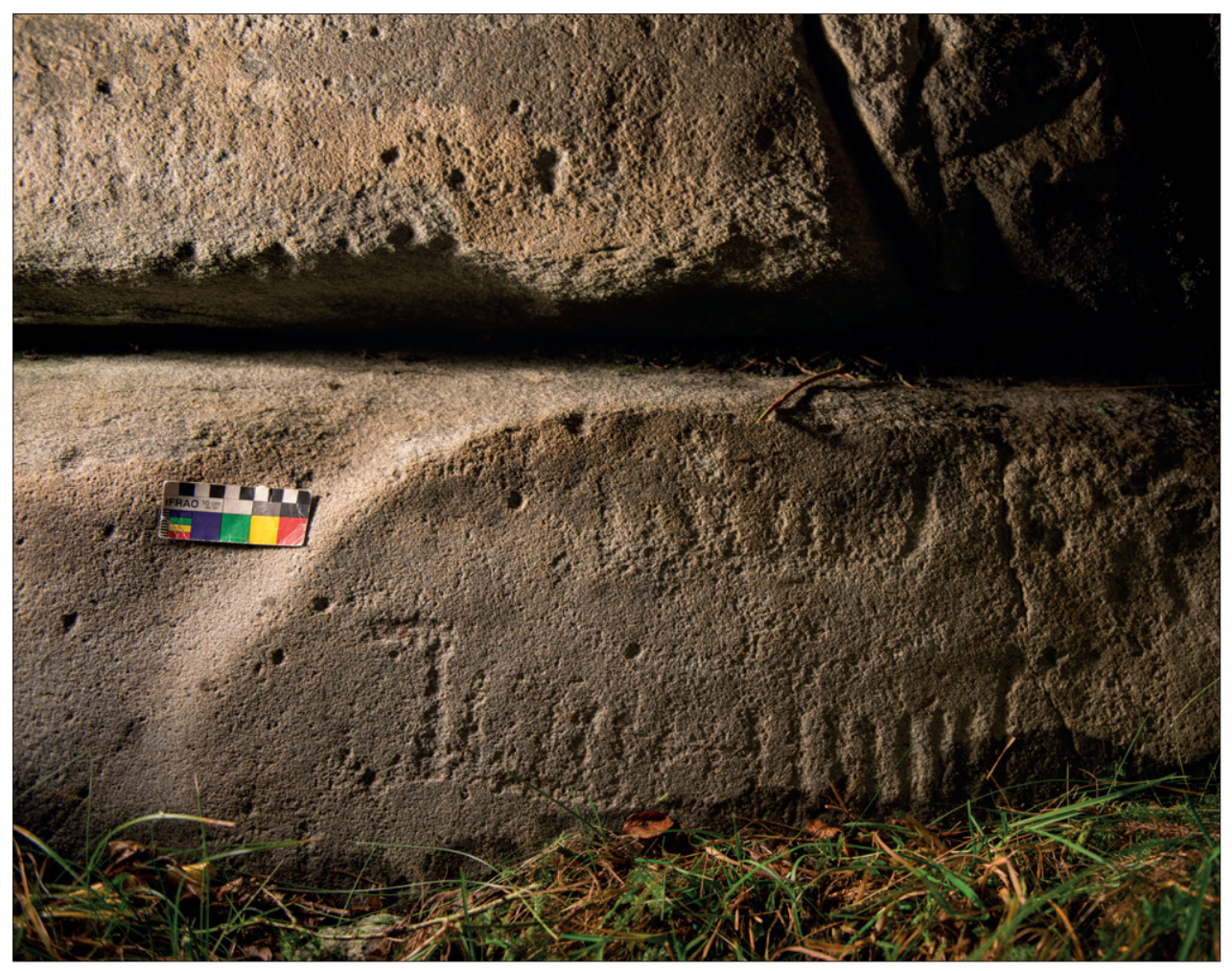

Fig. 23. Ny registrering av skip i 2015. Skipet kan ses mellom fig. 17 og fig. 19. Foto: $\AA$. Pedersen, AM, UiS.

Fig. 23. New image of a ship, found in 2015. The ship is recorded between figs. 17 and 19. Photo: Å. Pedersen, AM, UiS. 
krystallform. Apatitt finnes som spredte 0,05-0,2 mm store korn normalt uten tydelig krystallform, mens grafitt danner ørsmå inneslutninger i albitt og titanitt. Zirkon forekommer som sjeldne inntil 0,1 $\mathrm{mm}$ store korn som dels har en prismatisk krystallform. Oppløsningsporene i kalsittflekkene er mindre enn 0,2 mm i tverrsnitt.

Laminasjonen i gneisen faller slakt i vestlig retning og skjærer dermed flaten med figurene nokså vinkelrett. Flaten deles i tre av to åpne sprekker parallelt med laminasjonen.

Fjellets overflate, der figurene er hugget, virker temmelig solid om enn noe ujevn, men avskalling av noen få mm tykke fliser ser ut til å ha forekommet like sør for figurene. Små, mindre enn $1 \mathrm{~mm}$ tykke avskallinger finnes også ved noen av linjene i enkelte figurer, men har muligens oppstått da figurene ble hugget. Noen av figurene fremstår som lyse på et lysebrunt parti av fjellet. Dette skyldes at disse figurene er hugget gjennom et omtrent $1 \mathrm{~mm}$ tykt svakt rustent sjikt ytterst på fjellet. Brunfargingen er ikke til stede i figurenes linjer, noe som tyder på at rustfargingen er eldre enn figurene.

Skader pga. oppløsning av mineraler er som nevnt over begrenset til noe oppløsning av kalsitt, men siden prøven ble tatt ut der det så ut som om fjellet var blitt knust med slegge eller kanskje sprengt $i$, har nok flaten med ristninger vært eksponert over lengre tid. Noe mer kalsittoppløsning er derfor sannsynlig i flaten med ristninger, slik det ses i tynnslip fra feltene Vigdel og Ølbør III der fjellet er svært likt gneisen fra Hellestø, men siden kalsittinnholdet er svært lavt vil det ikke medføre alvorlig svekkelse av fjellet om all kalsitt løses opp. Det er dessuten overveiende sannsynlig at kalsitten i bergets overflate var løst opp før ristningene ble hugget. Bruk av slegge eller sprengning der prøven ble tatt ut, er antagelig årsaken til mikrosprekkene i tynnslipet, og det virker mest sannsynlig at disse ikke eller i liten grad er til stede ved figurene.

\section{Endringer over tid og skader påført av mennesker}

E. Fett og P. Fett (1941, s. 82) skriver at «fjellet er skurt av sandflukt, og nederste del av feltet er nesten helt glatt, og at linjene er ytterst svake». Som på Vigdel er de fleste av linjene prikkhugde i den betydningen at det er enkeltstående huggmerker på rad og ikke en sammenhengende linje. Av den grunn kan figurene ha blitt tolket som svake. De skriver videre at dette gjelder det meste av nedre del unntatt skipene nr. 17 og nr. 19 som er tydelige. Videre er strekene til nr. 8 også sikre, men svakere. Det antas at det må ha vært flere figurer i området, til venstre for figur $9 \mathrm{og}$ ved nr. 12. Mellom figur nr. $14 \mathrm{og} n \mathrm{nr} .21 \mathrm{og}$ flere andre steder er det imidlertid vanskelig å skille hogde fra naturlige linjer. De skriver videre at i øvre del er fjellet mer vitret og ristningene mer ødelagte.

Da Sømme Dahl (1985) besøkte lokaliteten, var det vanskelig å se selve figurene. Hun bemerket imidlertid at gneisen var begynt å skalle av i mm-tykke lag på oppsiden av knausene (dvs. ikke selve ristningsflaten). Dette mener hun kommer delvis av retningen på skifrigheten, nær parallell med overflaten, men at det også kan komme av at den ligger nær havet med mye saltsprøyt. Ellers er det avrundete is-skurte og sandblåste koller. På selve ristningsflaten er det forvitrete groper langsmed sprekkesystemene som er rundaktige, akkurat som overflaten av gneisen, og den virker uregelmessig ruglet. Hun konkluderer med at det ikke ser ut til at flaten er hullet, bare ruglet og gropet. Fjellet er relativt hardt med mye kvarts. Forvitringslaget på kollene der det er avskalling, er ca. 2 $\mathrm{mm}$ tykt. Rustbrun forvitring finnes ikke noe sted.

Ved ny skadekartlegging av konservator i 2009 ble det påvist eksfoliasjoner og mindre «bommer» over hele feltet. Bergflaten ble karakterisert som forvitret, der mye av den opprinnelige overflaten var borte (Bakke, 2009a). Som det framgår av ovennevnte ble det i den geologiske undersøkelsen samme år konkludert med at det forekommer en del mindre avskallinger ved linjene til noen figurer, men at dette kan stamme fra huggingen av figurene da flere figurer er hugget gjennom en svakt rustbrun forvitringsskorpe eldre enn figurene. Avskallinger er også til stede like sør for noen av de nederste figurene, men fjellet virker for det meste temmelig solid der figurene er hugget. Noe oppløsning av karbonatmineraler ble påvist i tynnslip, men karbonatinnholdet i gneisen er ikke så høyt at dette utgjør en fare for ristningene.

Som det framgår av ovenstående, er det en viss faglig uenighet $i$ hvor stor grad lokaliteten er utsatt for vitring og slitasje. Med den grundige dokumentasjonen som nå er utført på lokaliteten, vil det la seg gjøre å følge spesielt med på utviklingen mht. forvitring i framtida. Det er imidlertid ikke blitt påvist skader påført av mennesker.

Lokaliteten ble første gang malt opp i 1992 (Hernæs, 1992c). I dag er så å si all maling slitt vekk.

\section{I.3 KRÅKHAUG - VALHAUGKOMPLEKSET}

\section{Hedland gnr. 24, bnr. 1, 3, 26 - «Kråkhaug I», Id 65851}

Historikk, beliggenhet og presentasjon av lokalitet og figurer

Lokaliteten, også kalt «Kråkhaug», ble oppdaget i 1959 av B. Myhre i forbindelse med registreringsarbeid. Da ble det påvist kun ett skip. I 1963 foretok han grundigere undersøkelser på stedet, noe som resulterte i ytterligere 15 nye 


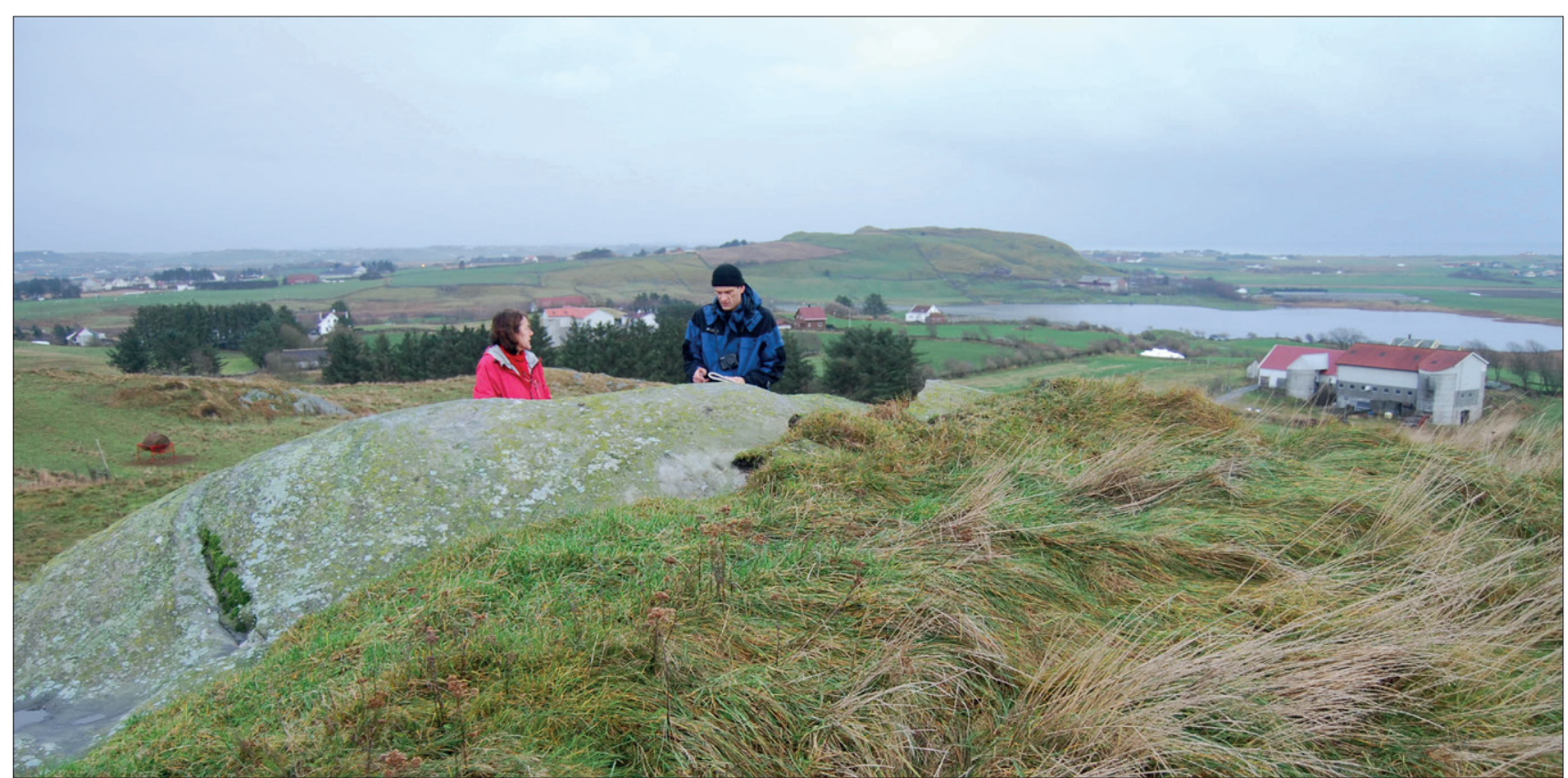

Fig. 24. Fra «Kråkhaug I» (id 6585I), Hedland, er det god utsikt mot Harvalandsvatnet og havet i vest.

Foto: L. Prøsch-Danielsen, AM, UiS.

Fig. 24. From the rock outcrop and rock art site «Kråkhaug l" at Hedland there is a nice view towards the lake Harvalandsvannet and the North Sea to the west. Photo: L. Prøsch-Danielsen, AM, UiS.

figurer. Lokaliteten ligger om lag 55 moh. i beitemark, høyt og fritt i terrenget med vidt utsyn mot Harvalandsvatnet og det nå uttappete Skadsvatnet, 250 m sørvest for husene på gården og om lag $1,5 \mathrm{~km}$ fra havet i vest, på sørsida av en fjellknaus som utgjør en nesten loddrett vegg (fra nesten vertikalt til rundt $60^{\circ}$ ) (Fig. 24). Veggen er 1-1,5 $\mathrm{m}$ høy og ca. $10 \mathrm{~m}$ lang (B. Myhre, 1964). Ristningene ligger nokså samlet midt på bergflata med bare $4 \mathrm{~m}$ mellom ytterpunktene. De nederste figurene befinner seg helt nede ved gresstorva, mens de øverste er plassert like under toppen av knausen (Fig. 25). Lokaliteten er delt inn i tre grupper (Fig. 26) der gruppe 1 består av tre skip og en dyrefigur, gruppe 2 av ett skip og fire, muligens fem, menneskefigurer, mens gruppe 3 består av fem skip og en dyrefigur (B. Myhre, 1981, s. 97-98). Tre av skipene er tolinjete, mens seks er enlinjete. Ut fra stilistiske trekk daterer B. Myhre lokaliteten til yngre bronsealder, og siden lokaliteten virker helhetlig, mener han at figurene kan ha blitt hogd innenfor et forholdsvis kort tidsrom (1964). Skipene er fortrinnsvis av typene A3 og B3 (Mandt, 1991, s. 47;

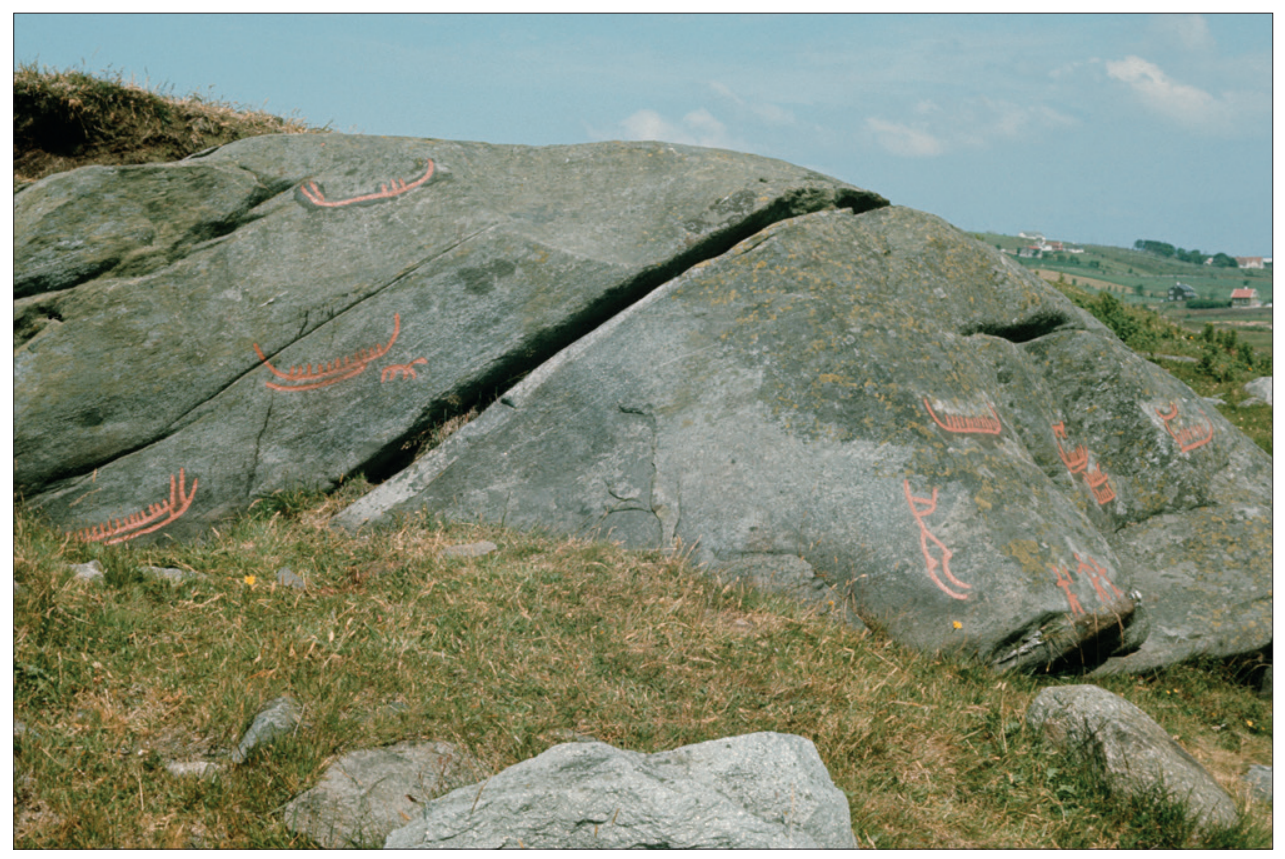

Fig. 25. De tre figurgruppene på «Kråkhaug I» sett mot NV i 1966. Foto: R. Utne.

Fig. 25. Three groups with images at «Kråkhaug I» seen towards NW. Photo: R. Utne. 
Wrigglesworth, 2011, s. 118), og dateringen er dermed i overensstemmelse med Myhres forslag (se også Kaul, 1998, s. 88, nr. 18).

Sammenlignet med rogalandsristningene for øvrig, som hovedsakelig består av skip og skålgroper, finner vi på «Kråkhaug» et mer variert figurutvalg med to dyrefigurer samt tre eller fire 12-15 cm høge «strekmennesker» hvorav to har tydelig fallos, alternativt kan det ene bære et sverd. De slår ut med armene og står med beina fra hverandre. Ovenfor disse er det ristet inn et $34 \mathrm{~cm}$ høyt "profilmenneske" (uten hode) med bøyde, markerte knær og med hevet øks som ser ut til å være i bevegelse. B. Myhre (1981, s. 97) mener at strekmenneskene viser mann og kvinne under samleie og selv om en ikke kan vite om det er en sammenheng mellom figurene, kan det se ut som øksemannen vokter eller signer de øvrige menneskefigurene. Også Kjeldsen (2017, s. 99) oppfatter framstillingen som en samleiescene. L.N. Myhre (2004, s. 93) tolker framstillingen i større grad som en «kampscene», hun setter figurene i sammenheng med sprekkene i fjellet og trekker inn skipet ovenfor hvor det er et tomrom mellom mannskapsstrekene og stiller spørsmål om det kan være en sammenheng.

Denne scenen er unik i vestnorsk sammenheng, selv om det finnes liknende komposisjoner på Bakke i Jondal, Hardanger (Sør-Reime, 1984a). Beliggenheten, med godt utsyn i alle retninger, kombinert med den spesielle figursammensettingen, gir lokaliteten særpreg.

\section{Bergart, geologisk vitring og slitasje}

Bergarten ristningene er hugget i er en finlaminert grå til gråhvit og kvartsrik glimmergneis. Analyse av et tynnslip laget fra en prøve tatt ut $14 \mathrm{~m}$ sørvest for figurene, der fjellet synes å være langt mer vitret og oppsprukket enn i selve feltet, gir et kvartsinnhold på $73 \%$ og et muskovittinnhold på $16 \%$. I tillegg opptrer $6 \%$ albitt, 2
\% brun biotitt, samt spor av zirkon, apatitt, gul turmalin, opake jern-titanoksider og rust (Fig. 27a og 27b). Prøven inneholder også i underkant av $1 \%$ porer dannet ved oppløsning av mineraler, antagelig karbonat, og et par prosent sprekkeporøsitet med spor av organisk materiale i noen av sprekkene. Kvartsen opptrer som en mosaikk av ekvidimensjonale til noe avlange krystaller uten tydelig krystallform og med tverrsnitt for det aller meste innen intervallet 0,1-0,5 mm. En svak tendens til orientering av lengste tverrsnitt for kvartskrystallene langs foliasjonen er tilstede, men foliasjonen er først og fremst definert av parallellorienterte 0,02-0,2 mm tykke flakformige krystaller av muskovitt og biotitt. Muskovitt og biotitt har en tendens til å være konsentrert i inntil 0,3 mm tykke lameller med lite innhold av andre mineraler, mens de mellomliggende kvartsdominerte lamellene har tykkelser som kan nå opp i $1 \mathrm{~mm}$. Albittkrystallene har omtrent samme størrelse og form som kvartskrystallene og opptrer enkeltvis eller noen få sammen og nokså jevnt fordelt i prøven. Det samme gjelder apatitt. Jern-titanoksidene opptrer som spredte velformete krystaller med størrelse mindre enn $0,15 \mathrm{~mm}$. Zirkon og turmalin forekommer som sjeldne, inntil 0,2 mm lange korn, uten tydelig krystallform. Rust finnes først og fremst på veggene i oppløsningsporene.

Laminasjonen i gneisen faller $35^{\circ}$ mot nord og skjærer dermed flatene med figurene nokså vinkelrett. Sprekker parallelt med laminasjonen forekommer, og noen av figurene krysser slike sprekker.

Fjellets overflate der figurene er hugget virker solid, nokså jevn og uten avskallinger.

Mange 0,01-0,1 mm tykke sprekker parallelt med laminasjonen ses i tynnslipet, og enda tynnere sprekker opptrer langs en del krystallgrenser. Prøven det ble laget tynnslip av var imidlertid langt mer vitret og skjør enn knausen der figurene er hugget, og en del sprekker kan

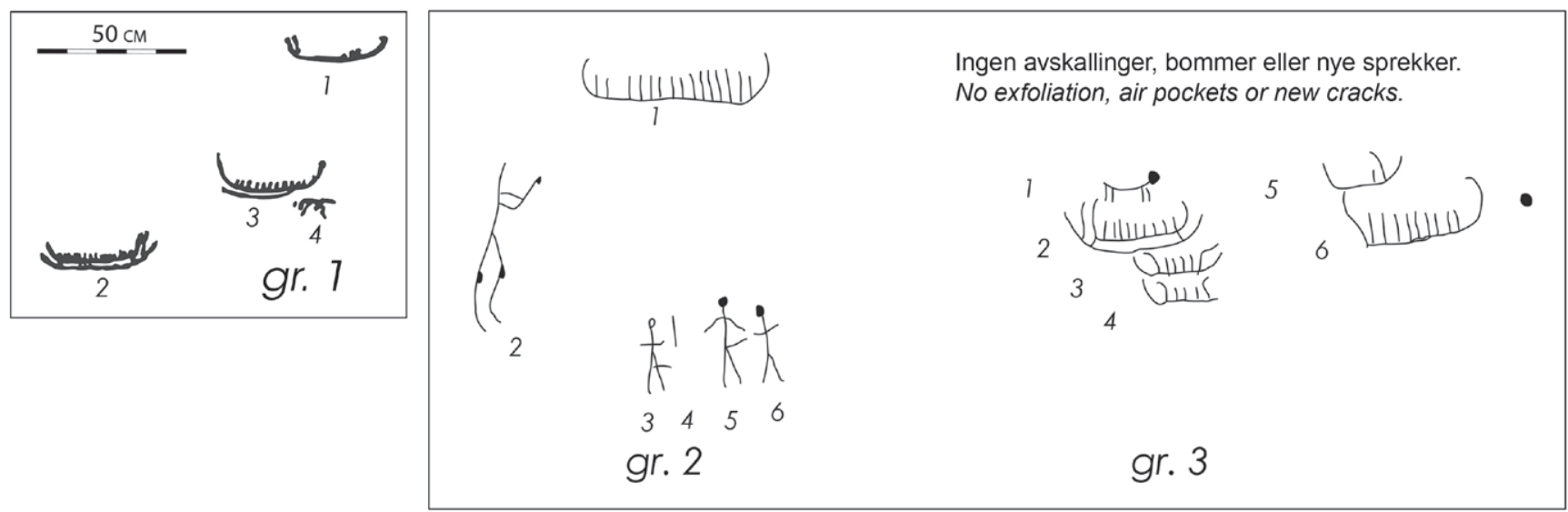

Fig. 26. Kalkering av ristningene på «Kråkhaug l» Hedland (Johnsen, 1968b) med påførte kommentarer (Bakke 2009a). Fig. 26. The rock art site at «Kråkhaug l», Hedland, traced by Johnsen (1968b) with notes by Bakke (2009a). 


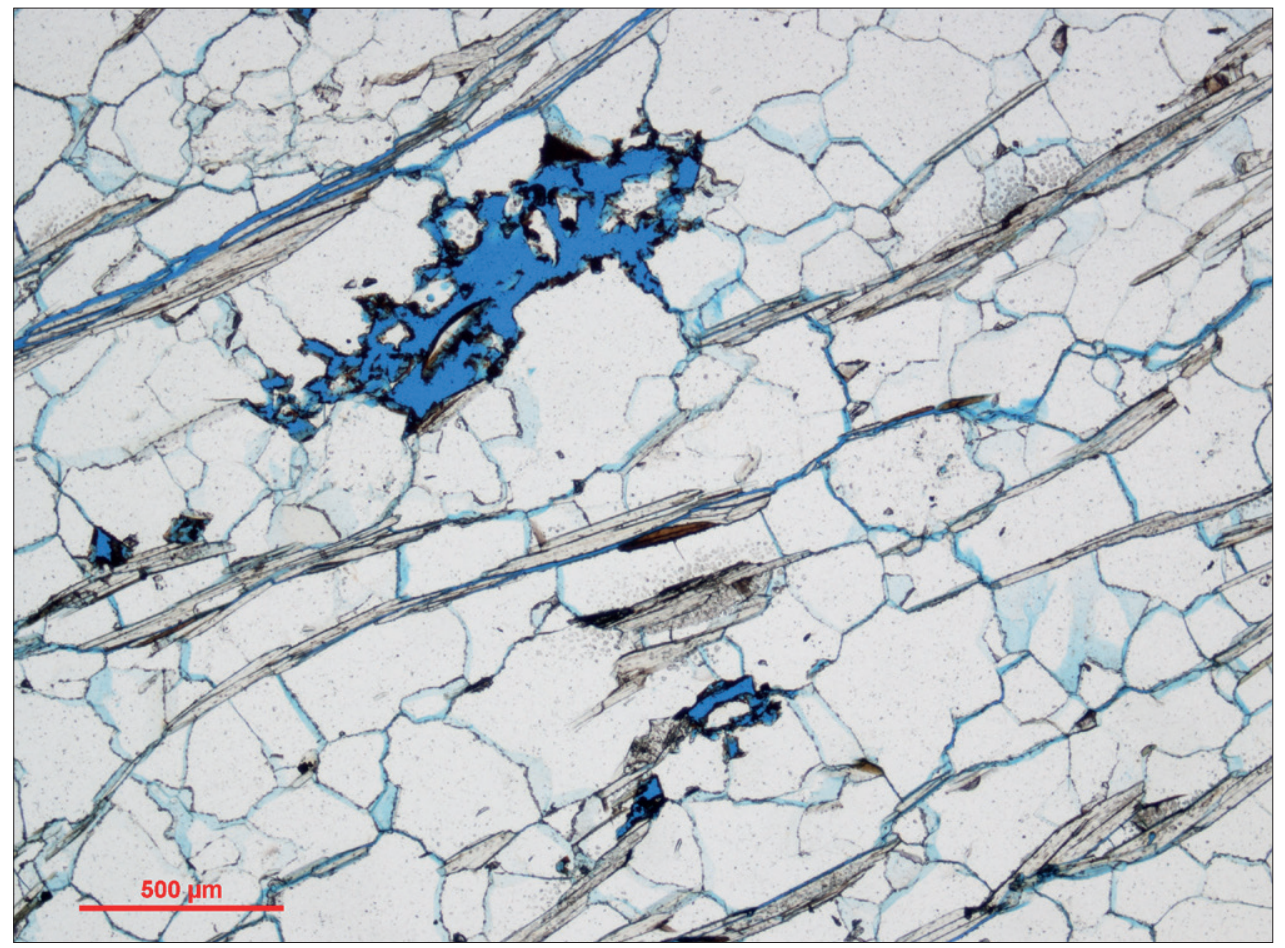

Fig. 27a. Tynnslipbilde av glimmergneis fra Kråkhaug I tatt med planpolarisert lys. Hvite områder består av kvarts og mindre mengder albitt. Avlange parallellorienterte hvite til grålige korn med kløv er muskovitt. Oppløsningsporer dannet ved oppløsning av karbonat samt tynne sprekker rundt korn er blå. Rust på veggene av oppløsningsporene er svart. Foto: $\mathrm{O}$. Walderhaug. Fig. 27a. Thin-section micrograph of gneiss from Kråkhaug I taken in plane-polarized light. White areas consist of quartz and minor volumes of albite. Parallel elongate white to pale grey grains with distinct cleavage are muscovite. Thin fractures around grains and dissolution pores after carbonate are blue. Rust on the walls of dissolution pores is black. Photo: 0 . Walderhaug.

være dannet eller utvidet under tynnslippreparering og prøvetagning. Enkelte porer, dannet ved oppløsning av karbonat, forekommer også, og rustutfellinger er vanlige på poreveggene. Volumet av oppløsningsporer er under $1 \%$, og relativt lettoppløselige mineraler som apatitt viser ingen tegn til oppløsning selv der de grenser mot oppløsningsporer. Det er dermed sannsynlig at svært lettoppløselig karbonat er det eneste mineralet i gneisen som har vært utsatt for oppløsning, og denne karbonatoppløsningen har antagelig overveiende funnet sted før ristningene ble hugget.

\section{Endringer over tid og skader påført av mennesker}

B. Myhre (1964, s. 6-7) beskriver bergflaten som glattslipt og fiellet som hardt og lite forvitret, men påpeker at figurene er grunt hogd og vanskelig å se selv med kunstig lys. Særlig gjelder dette gruppe 3 (B. Myhre, 1964, s. 11). Videre blir det påpekt at det øvre skipet (gruppe 1,

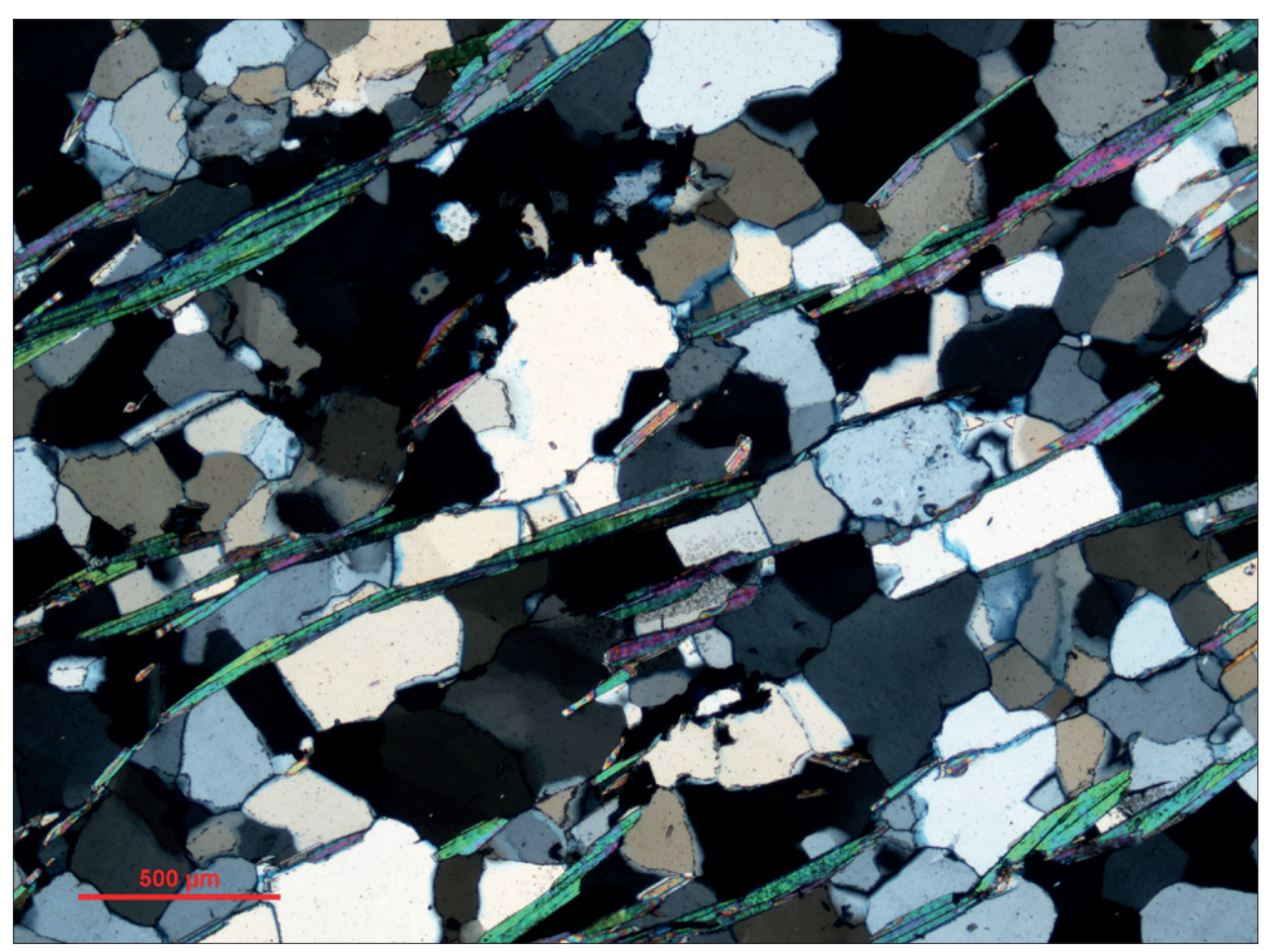

Fig. 27b. Tynnslipbilde av glimmergneis fra Kråkhaug I tatt med kryssede polarisasjonsfiltre. Kvarts og albitt er hvit, grå og svart mens avlange muskovittkorn er grønne og i noen tilfeller rosa og blà. Oppløsningsporer og rust har svart farge. Foto: O. Walderhaug.

Fig. 27b. Thin-section micrograph of gneiss from Kråkhaug I taken with crossed polarizers. Quartz and albite grains are white whereas elongate muscovite grains are green and more rarely pink and blue. Dissolution pores, fractures and rust are black. Photo: O. Walderhaug. 
figur nr. 1) er ødelagt av forvitring, at den loddrette streken muligens er rester etter et strekmenneske (gruppe 2, figur nr. 4) som delvis kan være vitret bort, at det nedre skipets østre stevn (gruppe 3, figur nr. 4) mangler, noe som sikkert er forårsaket av forvitring. Imidlertid mener han at årsaken til at hodet mangler på figuren med øks (gruppe 2, figur nr. 2) neppe skyldes forvitring.

Sømme Dahl foretok geologisk undersøkelse av lokaliteten i 1985 (Sømme Dahl, 1985). Bergarten (glimmergneis) ble karakterisert som relativt finkornet og fast, men hun påpeker at enkelte årer av kvarts står ut fra fjellet fordi fjellet omkring er erodert bort, sannsynligvis pga. sandblåsing. Hun observerte at det finnes enkelte små hull i fjellet, og at noen få flak har skallet av. Nede ved bakken ser det imidlertid ut til å være flere større groper. Videre skriver hun at det er flere sprekker i fjellet omkring ristningene, og at disse kanskje er fullstendig gjennomsettende og deler steinen i mindre biter. Langs sprekkene er mange inaktive erosjonsgroper som er dekket av lav. Sømme Dahl konkluderer imidlertid med at fjellet er solid og hardt og lite forvitret.

Bakke har observert og skadekartlagt lokaliteten flere ganger det siste tiåret, sist i 2009. Hun konkluderer med at alle ristningene ble gjenfunnet, og at det ikke ble observert nye avskallinger, sprekker eller «bommer» (Bakke, 2009a).

De fire beskrivelsene av de geologiske forholdene og lokalitetens tilstand, første gang utført i 1963, er nokså samstemte og indikerer at det ikke er mulig å påvise endringer/økende forvitring i løpet av denne tidsperioden. Det er heller ikke observert skader på lokaliteten påført av mennesker; sprengninger like ved i forbindelse med anleggelse av bunkere under 2 . verdenskrig ser ikke ut til å ha skadet ristningene.

Lokaliteten ble krittet opp i forbindelse med dokumentasjon i 1963 og malt opp med vanlig rød fabrikklaget maling i 1968 (Johnsen, 1968a, s. 154, 165). Johnsen skriver videre at det tidligere er brukt en blanding av engelsk rødt, linolje og parafin, men at denne malingen har vist seg for lite bestandig. I et notat fra 1982, skriver Vinsrygg (1982b) at lokaliteten skal males opp neste år. Dette ble sannsynligvis ikke gjort da Sør-Reime to år seinere foreslår oppmaling som et aktuelt skjøtselstiltak (1984a). Lokaliteten ble sist oppmalt i 1992 med rødbrun Drygolin med ren terpentin (Hernæs, 1992d). Få år seinere ble det observert at malingen skallet av, noe som ble forklart med at laven ikke var tilstrekkelig fjernet før oppmalingen; når laven da drepes og råtner bort, skaller også malingen av (Bakkevig, 1998b). Det står imidlertid fortsatt noe maling i furene.

\section{Hedland gnr. 24, bnr. 3 - «Kråkhaug II», Id 24685 \\ Historikk, beliggenhet og presentasjon av lokalitet og figurer}

På ei 6 x $4 \mathrm{~m}$ stor og om lag $2 \mathrm{~m}$ høy flyttblokk, ca 50 $\mathrm{m}$ sørøst for Id 65851, finnes en samling skålgroper,

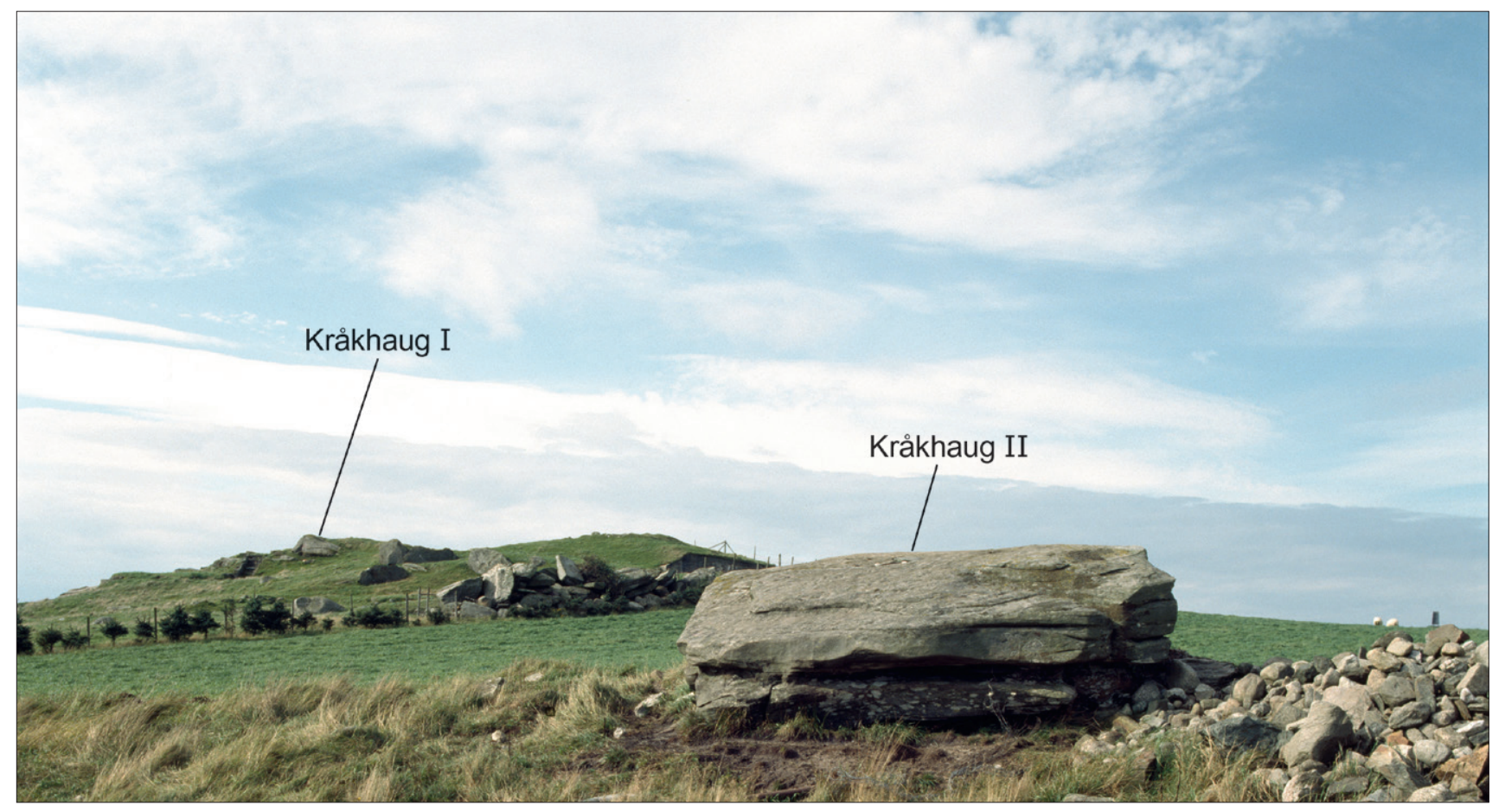

Fig. 28. Blokk «Kråkhaug Il» med skålgroper og fotsåler i år 2000. Bergkunstlokaliteten «Kråkhaug l» i bakgrunnen. Foto: E. Knutsen. Fig. 28. «Kråkhaug Il» a boulder with cup-marks and footprints seen in 2000. The rock art site «Kråkhaug l» is seen in the background. Photo: E. Knutsen. 
en mulig ringfigur og fire mulige fotsåler (Fig. 28). Flyttblokka ble første gang registrert av Egenæs Lund i 1939 (Egenæs Lund, 1939). Han skriver at de fleste figurene på steinen var skålformete groper, en fotsåle fantes i sørvest-kanten - ellers enkelte ubestemmelige linjer. Han omtaler også at på ei hylle på nordsida av steinen finnes to større skålformete groper, der den ene er ei om lag $20 \mathrm{~cm}$ langstrakt grop. Lokaliteten er kort omtalt av E. Fett og P. Fett (1941, s. 143) og av Johnsen (1974, s. 109) som også har kalkert enkelte av gropene. Han deler de om lag 30 gropene/figurene i fem grupper hvorav fire groper (inklusive en bekkenformet) ligger på ei hylle på nordsida av steinen, mens de øvrige ligger på den mer sørvendte sida av flyttblokka.

\section{Bergart, geologisk vitring og slitasje}

Flyttblokka består av en grå glimmergneis. Foliasjonen er omtrent horisontal slik at flatene med ristninger følger foliasjonen. Flatene med ristninger har ofte naturlige groper og oppragende partier med relieff på noen $\mathrm{cm}$, samt en noe ujevn overflate på mm-skala. Det siste skyldes antagelig en veksling mellom lameller rike på glimmer og lameller med høyt innhold av kvarts og feltspat.

Flatene med ristninger virker solide og uten synlige sprekker eller avskallinger. Sørvestre del av flyttblokka kunne imidlertid ikke undersøkes ved befaringen 18/11 2009 pga. en stabel med sprengningsmatter som var plassert oppå flyttblokka.

\section{Skader påført av mennesker}

Vinsrygg skriver i 1982 (1982b) at siden hennes siste befaring er området rundt den store gropsteinen blitt dyrka opp uten at fornminnet var skadet på noen måte. I 2000 lå det imidlertid rydningsstein ved og oppå flyttblokka. Disse var fjernet i 2003. I 2018 var imidlertid igjen store rydningsstein fylt opp inntil blokka.

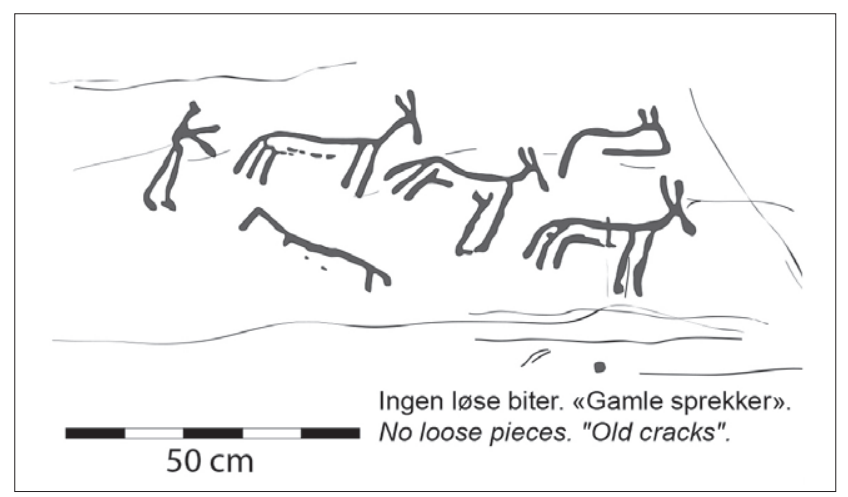

Fig. 29. «Dysjaland I/Valhaug I» (id I4882), kalkering (Johnsen, 1974, pl. 23A) med påførte merknader (Bakke 2009a). Fig. 29. The rock art site at «Dysjaland I/Valhaug I》, traced by Johnsen (1974, pl. 23A) with notes by Bakke (2009a).
Ristningene er tydelig hugget og godt synlige. Gropene ble malt opp i 1992 med rødbrun Drygolin med rein terpentin (Hernæs, 1992d).

\section{Dysjaland gnr. 27, bnr. 1, 2, 37 - «Dysjaland I/Valhaug I», Id 14882}

Historikk, beliggenhet og presentasjon av lokalitet og figurer

Lokaliteten ble påvist av grunneier i 1948. Han hadde i utgangspunktet meldt om funn av en mulig solfigur («Dysjaland II», Id 5528) og under registreringen gjorde han oppmerksom på mulige ristninger like ved (Møllerop, 1949a og 1949b). Etter å ha krittet opp de ulike linjene tolket Møllerop feltet til å inneholde en gjeterscene.

Lokaliteten ble fotografert, beskrevet og publisert, men først i 1971 ble den kalkert (Johnsen, 1971a) (Fig. 29). Feltet er seinere omtalt i ulike publikasjoner (Johnsen, 1974, s. 105; B. Myhre, 1981, s. 98; L. N. Myhre, 2004, s. 94). Figurene er hogd inn i en sørvendt flate på en østvestgående lav bergrygg (Fig. 30), like ovenfor det nå uttappete Skadsvatnet (se Fig. 6). I dag ligger lokaliteten i tunet på gården. Da Møllerop hadde krittet opp linjene framkom en menneskefigur og fem dyr. Dyrene er 20-30 cm lange og menneskefiguren om lag $20 \mathrm{~cm}$ høy. De fire øverste figurene er av samme type selv om bare tre av dem er fullstendige. Da de har lange rette horn og lang hale, ble de tolket som storfe. Det nederste dyret som er vendt motsatt veg er forskjellig fra de øvrige og ble av Møllerop tolket som en hund som skulle hjelpe til å holde flokken samlet.

Funnet vakte berettiget oppsikt, og melding om funnet sto å lese i lokalavisene 1. Mai (03.12. 1948), Stavanger Aftenblad (03.12. 1948) og Rogaland (03.12. 1948) samt i Aftenposten (03.12. 1948). Johnsen kalkerte som nevnt ovenfor figurene i 1971 (1971a) og fant ingen uoverensstemmelse mellom Møllerops oppkrittede foto og hans kalkering. Johnsen skriver (1974, s. 105) at ingen av figurene har full buklinje, men alle har en strek som muligens kan tolkes som kjønnssymbol, altså okser. Videre påpeker han at den nederste figuren er noe uviss og var inne på tanken om at den framstilte et jordbruksredskap, men ender opp med å skrive at dette er en figur lik de andre, men at den enten er forvitret eller ikke fullført. Han tolker m.a.o. ikke figuren som hund. Menneskefigurer er det ikke mange av i Rogaland og ifølge Johnsen (1974, s. 105) er det bare en figur som er like godt utformet, nemlig på «Kråkhaug» (id 65851). Oma (2018) tolker imidlertid dyrene som sauer - dette bla. pga. hundens plassering og forholdet mellom hunden og dyra. Etter vår oppfatning er dette den mest sannsynlige tolkinga. Å tidfeste lokaliteten er problematisk, men med kombinasjonen dyr og 


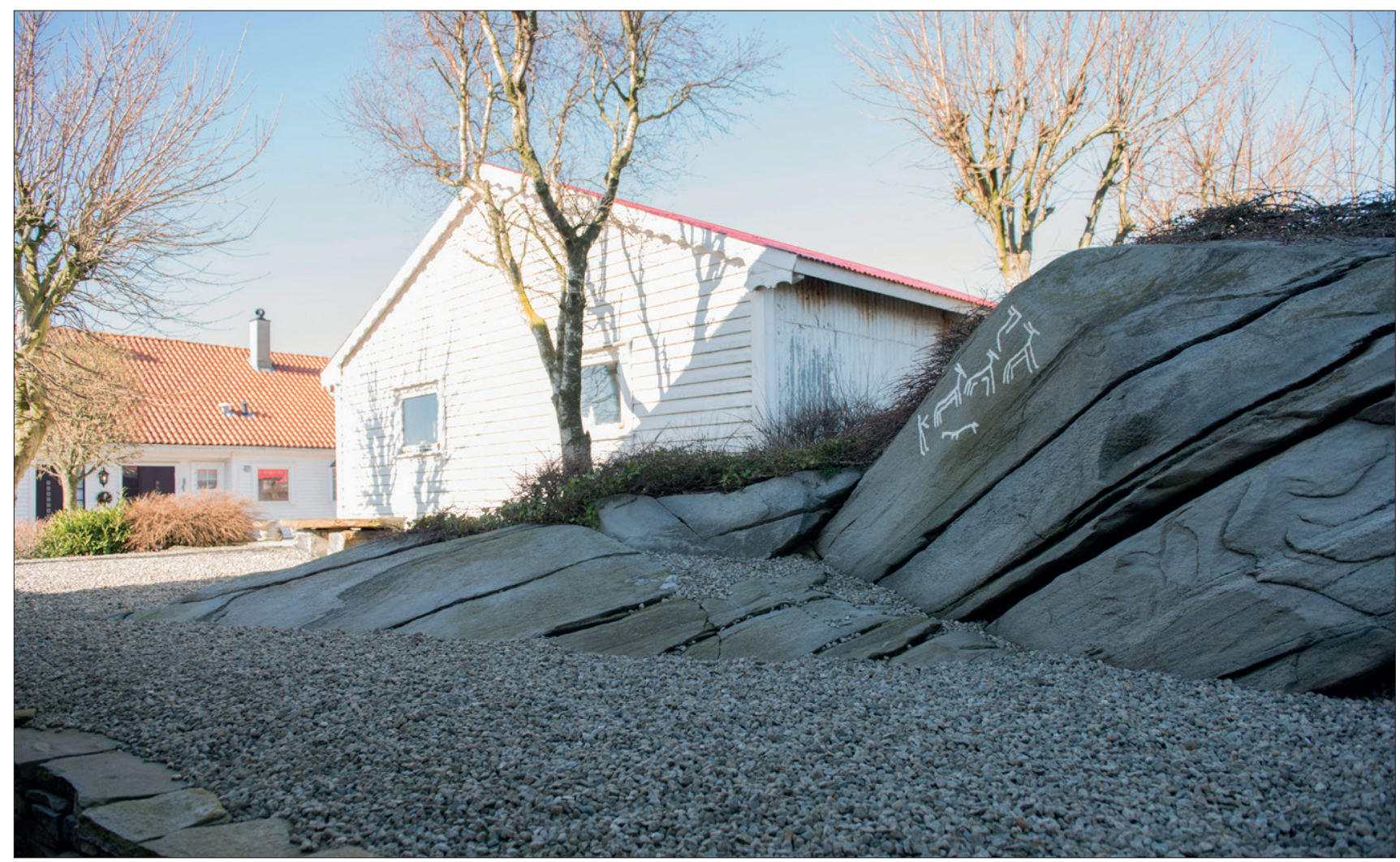

Fig. 30. «Dysjaland I/Valhaug I». Foto: Å. Pedersen, AM, UiS.

Fig. 30. The rock art site «Dysjaland I/Valhaug I». Photo: $\AA$. Pedersen, AM, UiS.

menneske er en datering til yngre bronsealder mest plausibel. Uten nærmere begrunnelse daterte Møllerop lokaliteten til yngre bronsealder, om lag 800 år f.Kr (1949b, s. 39). Dette er en spesiell lokalitet, og i vestnorsk sammenheng er den unik (Sør-Reime, 1984a). Gjeterscenen kan knytte feltet til Østfold-Bohuslän, men i sistnevnte område er imidlertid pløyescener mest framtredende.

\section{Bergart, geologisk vitring og slitasje}

Bergarten er en lys grå glimmergneis der laminasjonen faller ca. $30^{\circ}$ mot vest og skjærer den vertikale flaten med figurene omtrent vinkelrett. Det er ikke foretatt tynnslipanalyse av bergarten, men det virker sannsynlig at sammensetningen er omtrent som bestemt for tynnslip fra feltene Kråkhaug, Ølbør III, Vigdel og Hellestø, dvs. en gneis dominert av kvarts, albitt og muskovitt og med noe biotitt og andre mineraler.

Flaten med figurer er fri for sprekker, den inneholder noen mm-store huller, virker solid og uten større groper eller furer, men er ujevn på mm-skala.

De mm-store hullene kan være oppløsingsporer etter kalsitt eller andre karbonatmineraler slik det er påvist i tynnslip fra andre lokaliteter i Sola. Disse hullene har nok vært til stede før ristningene ble laget og utgjør ikke noen fare for figurene. Andre forvitringsskader ble ikke sett, og fjellet synes å være i god stand.
Endring over tid og skader påført av mennesker

Da Møllerop registrerte feltet første gang, beskrev han bergflaten som grov og sterkt forvitret. Han skriver at ristningene var så lite synlige uten sollys at en måtte kritte dem opp før fotografering. Bonden fortalte imidlertid at linjene kom tydelig fram ved kveldssol (Møllerop, 1949a og b). Sømme Dahl beskriver også feltet som ruglete, ujevnt og forvitret, men samtidig som hardt og tørt, og at det ikke er vannsig over ristningene. Hun trekker den konklusjonen at figurene ikke er spesielt truet. Videre påpeker hun at det ut fra fotografier ikke ser ut til å ha vært noen forandring fram til i dag (dvs. fra 1948 til 1985). Sør-Reime (1984a) påpeker også at det ikke er synlige skader. I 2009 ble lokaliteten på ny skadekartlagt og ingen «bommer», løse biter/eksfoliasjoner ble påvist. Heller ikke i naturlige sprekker ble det observert løse biter eller ferske avskallinger (Bakke, 2009a). I forbindelse med ny geologisk undersøkelse i 2009 ble det konkludert med at fjellet er i god stand og uten synlige skader.

Da Møllerop dokumenterte lokaliteten, ble den bare krittet opp. Grunneier hadde imidlertid etter dette holdt ristningene oppmalte fram til Johnsens arbeid med å kalkere lokaliteten startet i 1971 (Johnsen, 1971a). For å kunne utføre arbeidet var det nødvendig å fjerne malingen. Til dette arbeidet ble det brukt malings- og lakkfjerningsmiddel etter at kjemiker ved museet hadde 


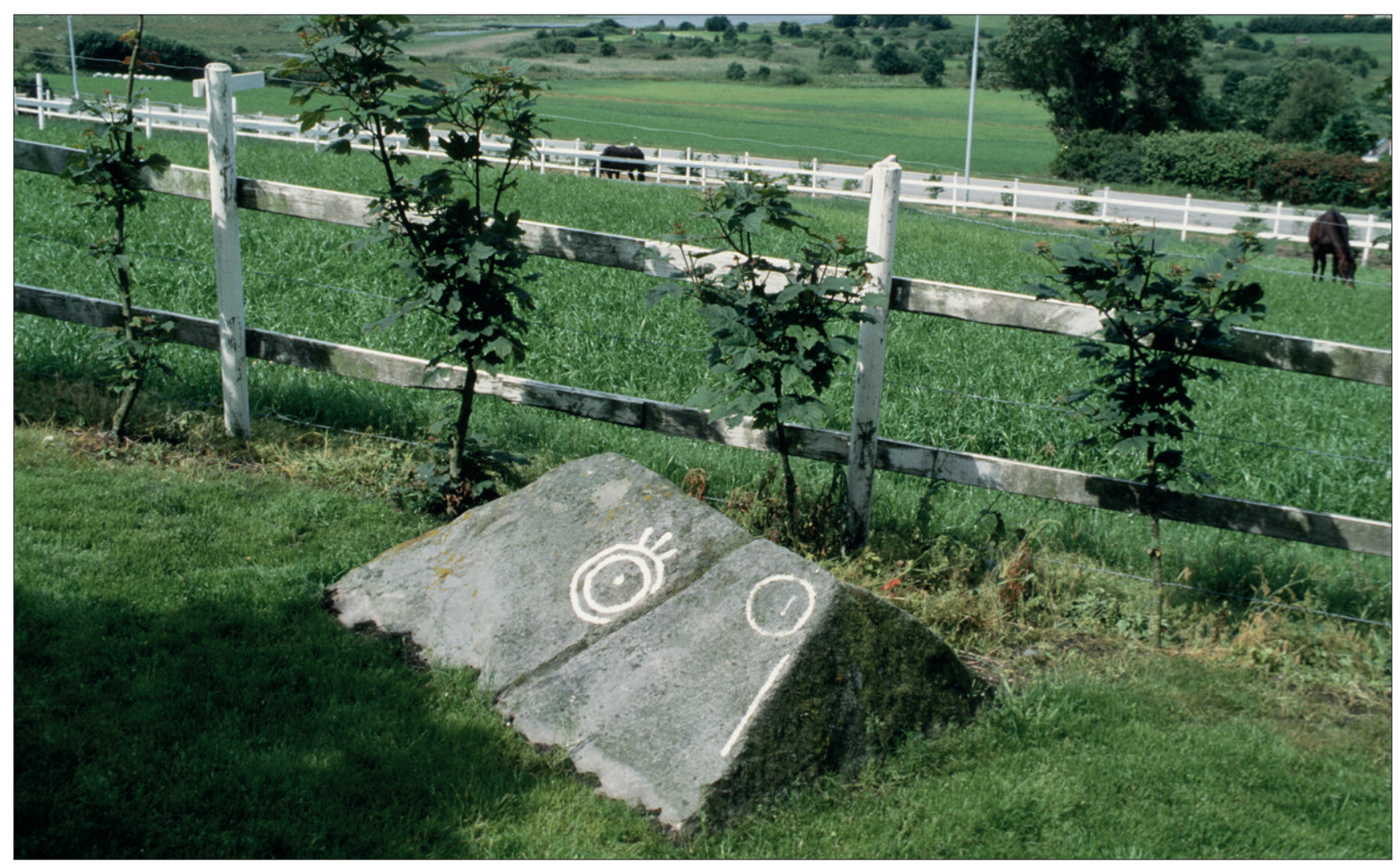

Fig. 3I. «Dysjaland II/Valhaug Il». Foto: Å. Pedersen, AM, UiS.

Fig. 3I. The rock art site «Dysjaland II/Valhaug II». Photo: $\AA$ Pedersen, AM, UiS.

konstatert at produktet hadde en så lav alkalitet at det ikke kunne skade bergoverflaten. Enkelte steder ble det nødvendig med fem påsmøringer. Etter hver påsmøring ble berget vasket med lynol og børstet lett med skurekost og stålkost. Til slutt ble berget spylt med vann. En del av malingskornene trengte inn i berget rundt ristningene, noe som ga ristningene et ureint utseende. Om lag en måned seinere ble det tatt avstøpning i silikon-kautsjuk. Avstøpningen ble skjemt av de gamle malingsrestene. Imidlertid gjorde støypinga sitt til at mesteparten av

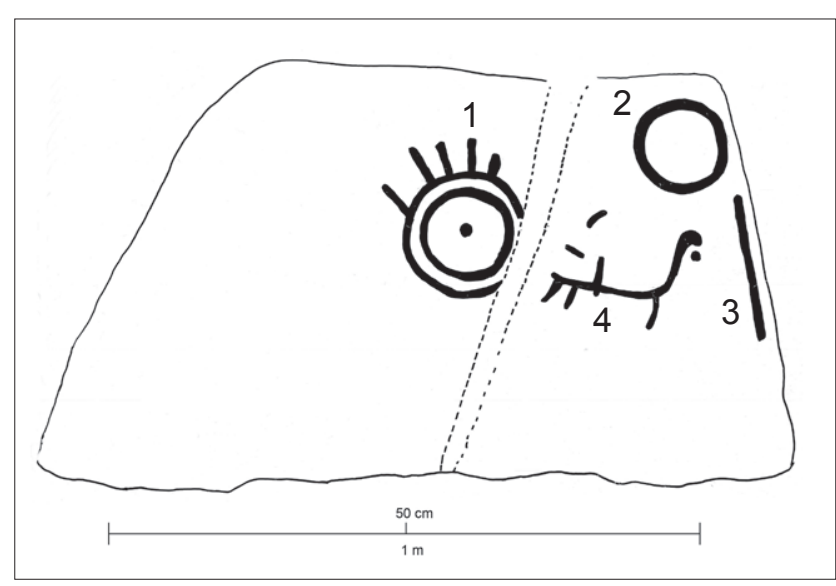

Fig. 32. «Dysjaland II/Valhaug II». Nykalkering av mulig hestefigur med rytter 2014. Kalkering av L. Prøsch-Danielsen. Fig. 32. The rock art site «Dysjaland II/Valhaug II». A probable horse figure traced in 2014 by L. Prosch-Danielsen. malingsrestene ble fjernet. I 2015 var det ikke spor etter dette. I forbindelse med kalkeringen ble ristningene malt med en blanding av fargepulver og vann. Etter en måned var vannmalinga borte. Figurene ble da gitt et tynt lag med maling av fabrikatet «Villa», type «slottsrød» (Johnsen, 1971a). Seinere er figurene blitt malt opp på nytt i hvitt av grunneier.

\section{Dysjaland gnr. 27, bnr. 1 - «Dysjaland II/Valhaug II», Id $\mathbf{5 5 2 8}$}

Historikk, beliggenhet og presentasjon av lokalitet og figurer

Lokaliteten ble første gang registrert av Møllerop i 1948 (Møllerop, 1949a og 1949b) etter at grunneier hadde varslet om funn av en helleristning på gården; et mulig soltegn. Figurene som er hogd inn i en jordfast stein ligger om lag 75 m nord for driftsbygningen på bruket med vid utsikt mot vest, nord og sør like ovenfor det nå uttappete Skadsvatnet med utsikt mot Harvalandsvatnet (se Fig. 6). I dag ligger steinen i østkanten av en hestehage. Figurene ligger på steinens plane sørside. Det er i dag registrert fire til fem figurer, mens Møllerop påviste tre (Fig. 31, kun de opprinnelige tre er malt opp). Figur 1 er en dobbel sirkel med sentralpunkt. Opp fra ytre sirkel stikker det opp fem takker (kun tre er malt opp). Figuren kan minne om figur 11 på Aubeberget i Stavanger kommune (id 54248) med 
midtpunkt og to sirkler. Denne har imidlertid bare en takk opp, i tillegg er det to små sirkler inni figuren (se Høgestøl et al., 2006, s. 33). Figur 2 er en sirkel uten sentralpunkt. Figur 3 er ei $24 \mathrm{~cm}$ lang og 1,5 cm bred snorrett linje. Det er ikke direkte forbindelse mellom figurene 2 og 3 . En del av steinen er sprengt bort og muligens er resten av figuren som streken tilhører nå borte. På en annen side finnes også slike enkeltstreker nær andre figurer, for eksempel på lokaliteten Kjøbenhavnerbukta (id 24609) i Stavanger kommune (se Høgestøl et al., 2006, s. 27). Under en grunnfagsekskursjon i 1973 ble det oppdaget en figur til, tolket som en mulig dyrefigur eller et enlinjet skip (om lag $15 \mathrm{~cm}$ lang) (Johnsen, 1974, s. 106). Denne figuren som er hogd mye svakere enn de øvrige, har vært oversett, dvs. den er ikke malt opp, ikke kalkert eller omtalt i Askeladden eller i ulike innberetninger som omhandler tilstandsrapporter og skjøtselarbeid utført på lokaliteten. B. Myhre (1981, s. 99) var imidlertid klar over figuren og beskriver den som en oksefigur. I 2009 ble figuren nyregistrert og kalkert i 2014 av forfatterne (fig. 32), og ut fra nye undersøkelser er det rimelig å tolke ristningen som en hest, muligens med spor etter rytter? Dersom dette er framstilling av en rytter til hest, kan lokaliteten dateres til yngre bronsealder (Marstrander, 1963; Vogt, 2012). Møllerop så lokaliteten i sammenheng med Dysjaland I og daterte begge, uten nærmere begrunnelse, til yngre bronsealder, om lag 800 f.Kr. (Møllerop, 1949a, 1949b, s. 39).

Lokaliteten inneholder en spesiell og interessant solfigur med unike detaljer samt en dyrefigur, antakelig en hest med rytter, en svært interessant kombinasjon.

\section{Bergart, geologisk vitring og slitasje}

Steinen med figurer består av grå, laminert glimmergneis. Flaten med figurer er omtrent parallell med laminasjonen og delt i to av en flere cm brei og dyp sprekk. Overflaten virker temmelig glatt og hard, men med ujevnheter, mest på mm-skala. Overflaten med figurer virker hard og solid og er uten avskallinger eller sprekker annet enn den store sprekken som deler flaten i to. Det synes ikke å være fare for større skader pga. forvitring i overskuelig framtid.

\section{Endringer over tid og skader påført av mennesker}

Møllerop beskriver linjene som dypt og kraftig hugget med jevne kanter (Møllerop, 1949b, s. 37). Johnsen (1971b) skriver også at linjene er så dype at det ikke var nødvendig å fargemarkere ristningene før de ble kalkert. Sømme Dahl (1985) påpeker imidlertid at selve steinen er forvitret med hull, men hun konkluderer med at det er en hard og fast bergart, og at ristningene ikke er særlig truet. Ved skadekartlegging i 2009 (Bakke, 2009a) ble det ikke oppdaget bommer eller avskallinger og som nevnt ovenfor viste de geologiske undersøkelsene at faren for større skader pga. forvitring er minimal i overskuelig framtid.

På oversiden av figur 2 finnes imidlertid en naturlig sprekk (Bakke, 2009a). Møllerop (1949b, s. 37) påpeker at området der steinen ligger er oppdyrket, og det er tydelig at en del av den er sprengt bort slik at resten av det bildet som streken (se fig. 31) tilhører er forsvunnet. Da Johnsen kom for å kalkere ristningen (1971b), hadde grunneier ønske om å sprenge bort eller flytte steinen da den lå ulagelig til midt i åkeren. Det var alt boret et hull i steinen. Dette ble forhindret, og den ligger fortsatt in situ.

Johnsen skriver i et notat fra 1971, at det ikke var nødvendig å fargemarkere ristningene før kalkering (1971b), men Sør-Reime foreslo oppmaling som et aktuelt skjøtselstiltak (1984a), noe som ble gjennomført i 1985 (Sør-Reime 1985a). Antakelig ble det nyttet rødmaling. Tre av figurene er imidlertid i dag malt opp med hvitt av grunneier.

\section{Dysjaland gnr. 27, bnr. 11, 18 -}

\section{«Dysjaland III/Valhaug III», Id 14884}

\section{Historikk, beliggenhet og presentasjon av lokalitet og} figurer

Lokaliteten er første gang nevnt av B. Myhre (1964, s. 14) der det kort står at «et tredje felt på Dysjaland, bestående av fem konsentriske ringer og en skålgrop innhogd på en sørvendt bergflate». I forbindelse med registrering for Økonomisk kartverk i 1968 skrev registratorene at feltet består av minst fire mindre båter med forholdsvis få mannskapsstreker per båt. Linjene er nokså utydelige i den grovkornete bergarten. Høyst sannsynlig finnes det «flere ristninger på den delen av berget som er dekket av torv» (Haaland \& Berge, 1968). Johnsen skriver i

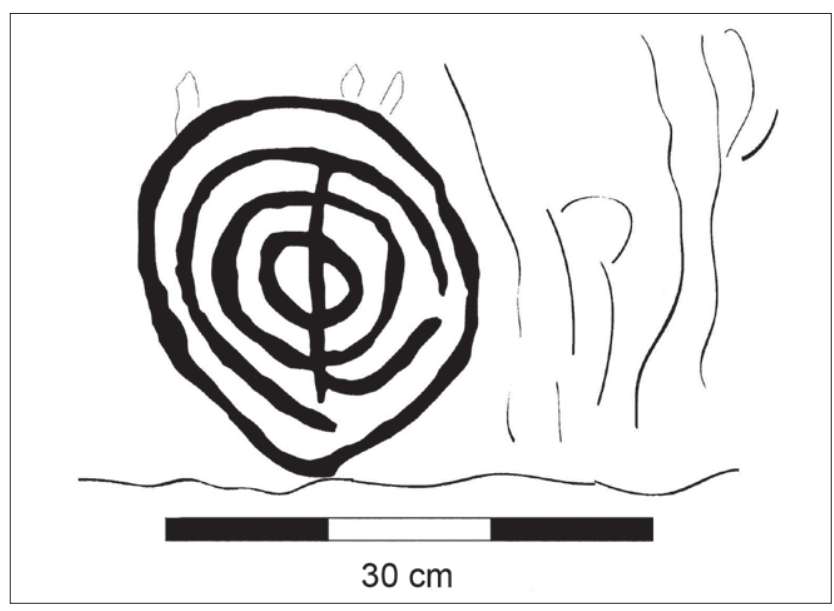

Fig. 33. «Dysjaland III/Valhaug III» kalkering av ringfigur (Johnsen, 1974, pl. 23B).

Fig. 33. The rock art site «Dysjaland III/Valhaug III». A figure with concentric rings has been traced (Johnsen, 1974, pl. 23B). 


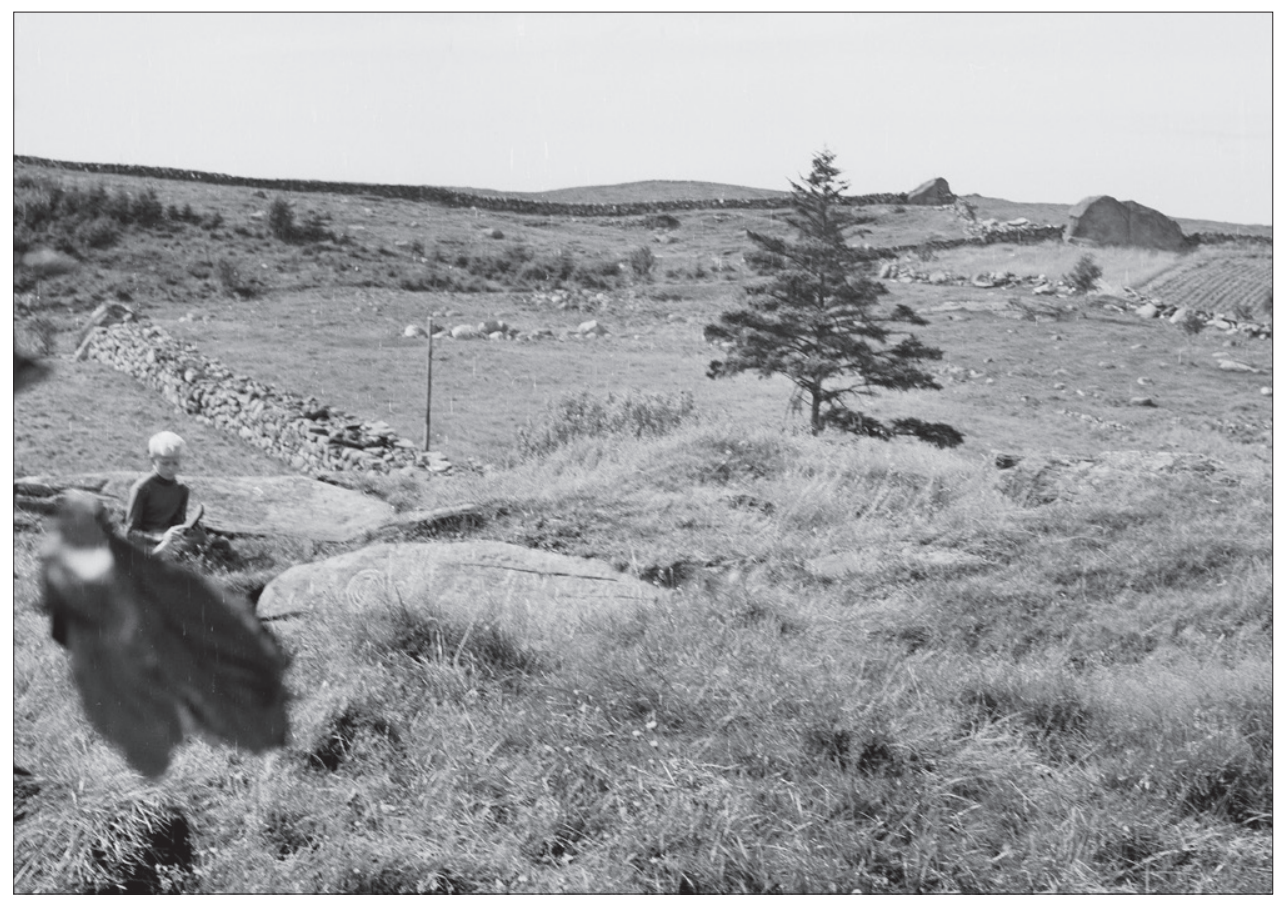

Fig. 34a «Dysjaland III/ Valhaug III». Landskapet rundt lokaliteten i 1972. Foto: J. Johnsen.

Fig. 34a. The landscape in the vicinity of the «Dysjaland III/ Valhaug IIl» carved figure. Photo from 1972. Photo: J. Johnsen.

et notat (1971c) at det kan se ut som om det dreier seg om to ulike lokaliteter, men da han vendte tilbake til lokaliteten i 1971, viste grunneierens sønn straks ei flate som svarte til begge omtalene. På flata fant han figuren med de konsentriske sirklene og en del uklare streker som fortsatte under torva. Han fjernet torva og renset fram bergflata og gransket furene både i dagslys og med lykt under svart plast. Alle linjene som ikke så ut til å skyldes isskuring eller forvitring, ble krittet opp. Disse linjene skilte seg imidlertid sterkt ut fra de i ringfiguren; de var vekslende i bredde og dybde samt både krokete og glatte i bunnen. Konklusjonen var at disse linjene ikke var menneskeskapte (muligens dannet ved røtter som hadde presset seg inn i fjellet). Johnsen kalkerte ristningen (Fig. 33), og som det framgår består figuren av 4-5 konsentriske sirkler, en radiær linje som går fra sentrum til tredje sirkel samt muligens tre korte linjer fra ytterste sirkel (jf. Dysjaland II). I 2009 ble linjene undersøkt på nytt, og det ble igjen konkludert med at lokaliteten høyst sannsynlig bare består av den ene figuren med konsentriske sirkler samt ei mulig skålgrop. Slike store og sammensatte ringfigurer er forøvrig sjeldne i Rogaland. Lokaliteten kan ikke dateres nærmere enn til bronsealder da slike sirkelmotiv har stor tidsdybde.

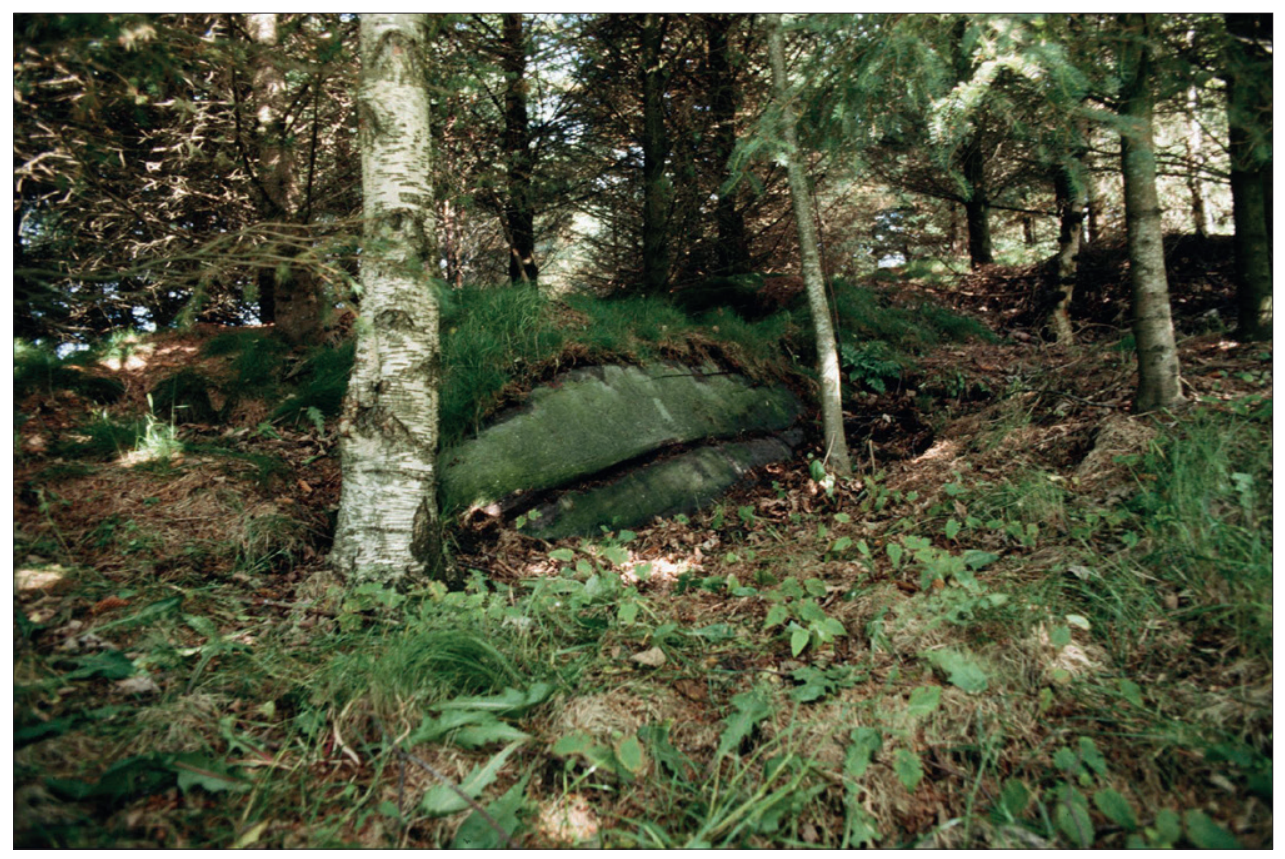

Fig. 34b. «Dysjaland III/Valhaug III» i tett bjørk- og granskog i 1999. Foto: Å. Pedersen, AM, UiS.

Fig. 34b. The landscape at "Dysjaland III/Valhaug III» was densely forested by birch and spruce in 1999. Photo: $\AA$. Pedersen, AM, UiS. 
Lokaliteten som ligger på en sørøst-vendt bergflate er i dag omgitt av plantet granskog på en bergkolle om lag 20 $\mathrm{m}$ nord for bolighuset på bruket. Bergkollen ligger straks nord for bunnen av et lite dalsøkk som går fra det nedtappete Harvalandsvatnet til det uttappete Skadsvatnet. Fig. 34a og 34b viser området i 1972 og i 1999 før grønske ble fjernet med etanol.

\section{Bergart, geologisk vitring og slitasje}

Bergarten er en grå laminert glimmergneis. Figuren er hugget på en sprekkeflate orientert nokså vinkelrett på laminasjonen. Overflaten er ujevn på mm-skala, og har også en del groper og furer med relieff rundt en halv cm. Noen åpne dyptgående sprekker parallelt med laminasjonen krysser deler av flaten, men sprekkene er eldre enn figuren, og figuren er lagt utenom sprekkene.

Feltets overflate er ujevn, og som nevnt over forekommer noen dype gamle sprekker parallelt laminasjonen i fjellet, men det ser ikke ut til at forvitring truer figurene. Dette kan imidlertid endre seg dersom trærne som står nesten oppå feltet får utvikle seg, og røtter trenger inn i sprekkene.

\section{Endring over tid og skader påført av mennesker}

Registratorene for Økonomisk kartverk betegnet fjellet som grovkornet (Haaland \& Berge, 1968). Sømme Dahl skriver at flaten er tørr, uten vannsig, men den er ruglete med små groper og enkelte hull. Prøve tatt $50 \mathrm{~m}$ øst for feltet viser at forvitringsskorpen bare er et par mm (Sømme Dahl, 1985). Ved skadekartlegging i 2009 ble det ikke påvist «bommer», ingen avskallinger, og fjellflaten ble beskrevet å være i god stand (Bakke, 2009a). Ved ny geologisk kartlegging i 2009 ble det konkludert med at fjellet er i god stand, men at der er fare for at feltet snart dekkes av torv, og at røtter fra trærne rundt feltet kan utvide sprekkene i flaten med figurer.

Sør-Reime skriver i 1984 at lokaliteten ikke er malt opp, og at dette er et aktuelt skjøtselstiltak (1984a). Tiltaket ble gjennomført i 1985 (1985a). Ved registrering i 1999 i forbindelse med utfylling av Riksantikvarens dokumentasjonsstandard, ble det konstatert at det var malingrester i linjene. Svake spor etter maling kunne også ses i 2017.

\subsection{Landskap i endring}

Dette landskapet har stadig vært i endring som følge av endringer i havnivået. Få steder i landet vårt er landskapsutviklingen mer komplisert enn nettopp langs denne kyststrekningen. Siden 1900-tallet har også flere av vannene blitt senket eller blitt helt borte gjennom drenering og uttapping (i 1903 og 1953), og det kan derfor være vanskelig å se for seg det landskapet bronsealdermennesket levde i. I 1983 foretok Thomsen (Thomsen, 1983) sedimentboringer i dette området, og ved hjelp av disse data har vi gjenskapt utviklingen og endringene i landskapet gjennom tidene (Fig. 35a-d).

To strandvollsystemer løper parallelt langs denne kyststripa. Den eldste strandvollen, kalt Rinnå, ligger høyest i terrenget (ca. 9-12 m over dagens havnivå). Fægri $(1936,1940)$ påviste at denne strandvollen ble dannet ved transgresjonen (havstigningen) som fant sted relativt kort tid etter at isen trakk seg bort fra området i perioden Yngre Dryas, og han var den første i verden som påviste at en slik senglasial transgresjon hadde funnet sted. I området ved utløpet av Figgjoelva bøyer imidlertid denne strandvollen innover i landet og demmer blant annet opp Alvevatn. Litt lenger nord demmer Rinnå opp sør- og vestendene av tidligere Mosvatn og Tangarvatn/Selevatn. Bronsealderhaugen Tangarhaug er plassert lett synlig oppå Rinnå like vest for Mosvatn. Vest for Mosvatn stakk også fast fjell opp i dagen som en langstrakt rygg, og Rinnå følger i forlengelsen av denne ryggen nordover parallelt med kysten. Sammen med tidligere Ølstervatn drenerte disse vannene derfor nordover over Bybergsletten og brøyt først igjennom Rinnå og ut i havet ved Moen i nord (Fig. 35a).

Etter den eldste transgresjonen fulgte en periode på omkring 1000 år der havnivået sank før den nye transgresjon, kalt Tapes-transgresjonen, startet for vel 8000 år siden, med en første topp om lag 5400 f.Kr. I dette området hadde denne transgresjonen som tidligere nevnt to topper med 1500 års mellomrom. Den siste toppen var høyere enn den første (om lag 9-10 m over dagens havnivå) og nådde sitt maksimum om lag 4000 f.Kr. ved inngangen til yngre steinalder. Store områder langs Figgjodalen var oversvømt. Havvannet gikk videre inn i Grudevatn og nådde også inn i Skadsvatn (Fægri, 1940) (Fig. 35b). Det oppsto ei havbukt innover «dalen» og det samme var tilfelle over deler av Sele/Bybergsletta. Det var mulig å seile inn til Soma og ta seg derfra østover til Høgsfjorden i Sandnes (2,5 km til fots). Flere gravhauger fra eldre bronsealder er plassert langs nordsiden av dette innløpet. Disse kan også markere sentrale knutepunkter i landskapet (jfr. Fig. 3).

Brakkvannssedimenter ble dannet i disse lagunene, og seinere grodde det til med torv. Det er gjort funn av torv og trerøtter datert til eldre steinalder i Harvalandsvatnet. Dette viser at vannstanden seinere er blitt hevet. Harvalandsvatnet hadde et mindre omfang i eldre steinalder enn i bronsealder og fram til 1903. En endelig senkning fant sted i 1903 (Holmsen, 1922; Thomsen, 1983). En slik vannstandshevning kan ha skjedd ved at terskelen, 


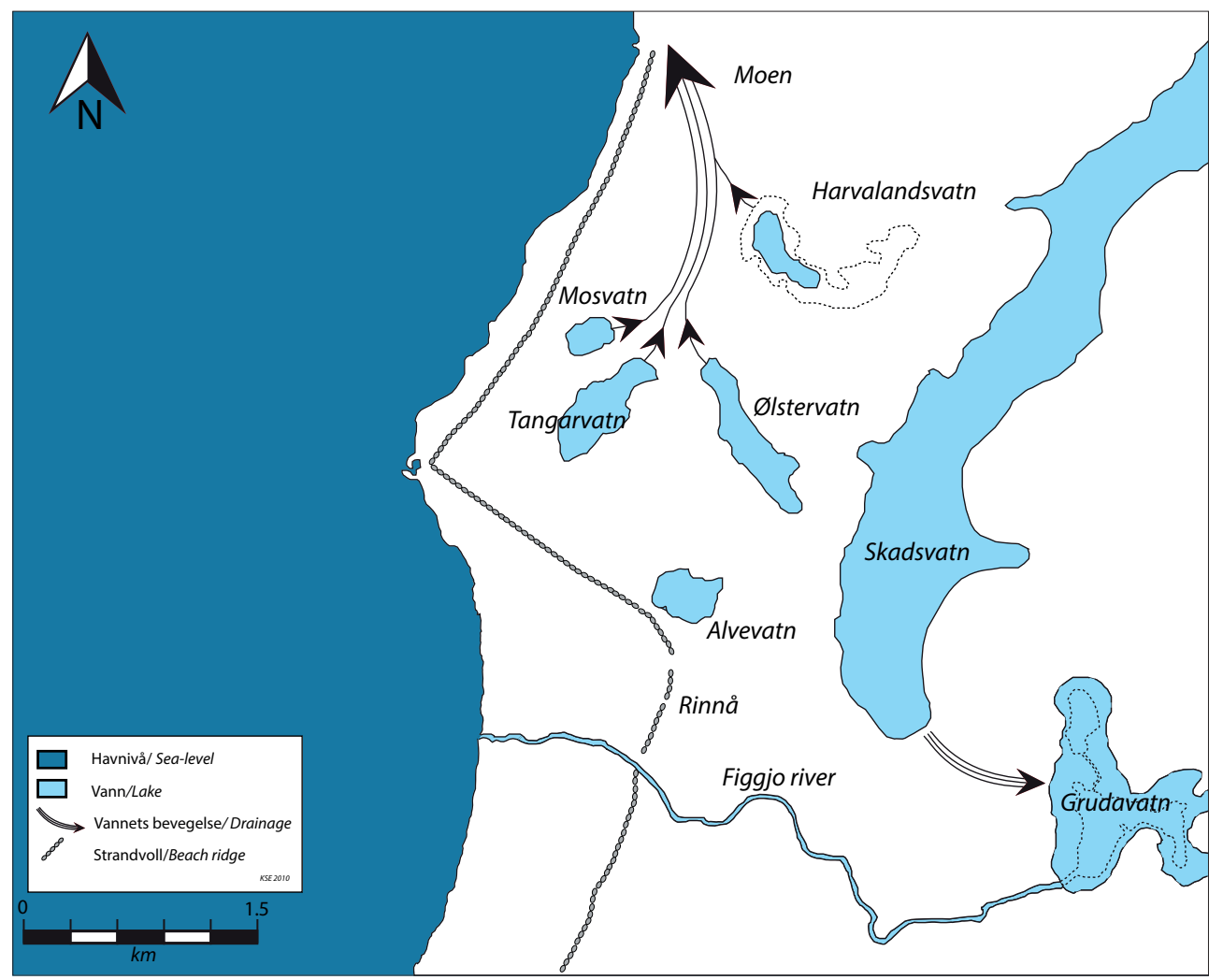

Fig. 35a. Landskapet mellom Hellestø og utløpet av Figgjoelva i mesolitikum, med eksisterende vann og dreneringsforløp (etter informasjon hentet fra Fægri, 1940, Thomsen, 1983). Kart: L. PrøschDanielsen \& K. Eilertsen, AM, UiS.

Fig. 35a. The landscape between the rock art site Hellestø in the north and the river Figgjo in the south in the Mesolithic. Four of the former lakes (Mosvatn, Tangarvatn, Ølstervatn and Harvalandsvatn) drained towards Moen in the north (information from Fægri, 1940 and Thomsen, 1983). Dark blue $=$ the North Sea, light blue $=$ lakes, arrows $=$ drainage, dotted line $=$ beach ridge system. Drawing: L. Prøsch-Danielsen \& K. Eilertsen, AM, UiS.

utløpet av bassenget eller utløpet ved Moen, ble demmet opp. Den mest sannsynlige forklaringen er at sedimenter har blitt akkumulert på Sele/Bybergsletta mellom Harvalandsvatnet og Rinnå under Tapes-transgresjonene (som marin sand) eller under den påfølgende havsenkningen som fulgte (som eoliske avsetninger). Store områder lå blottlagte for erosjon utenfor Harvalandsvatnet gjennom yngre steinalder og bronsealder, og sandflukt ble resultatet (Prøsch-Danielsen \& Selsing, 2009) (Fig. 35c). Ved Bybergsletta og på Moen i nord er toppen av et torvlag skjult under flyvesand, datert til om lag 2400 f.Kr. og til 3500 f.Kr. Starten på denne sandflukten er datert tilbake

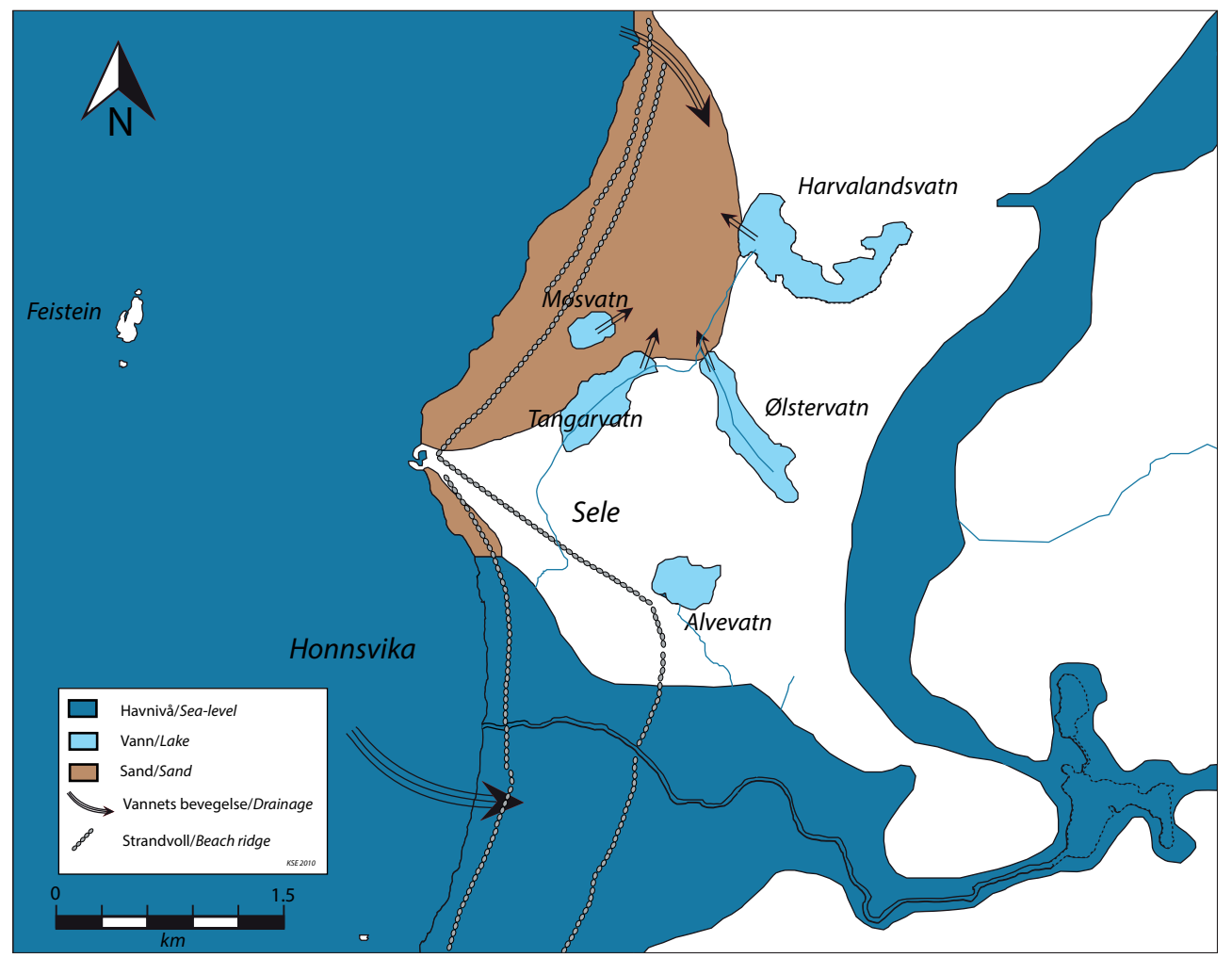

Fig. 35b. Landskapet mellom Hellestø og utløpet av Figgjoelva omkring 4000 f.Kr. når 2. Tapestransgresjon når sitt maksimum. Havvannet når inn til Grudavatn og Skadsvatn. Kart: L. PrøschDanielsen \& K. Eilertsen, AM, UiS.

Fig. 35b. The landscape between the rock art site Hellestø in the north and the river Figgjo in the south approximately $4000 \mathrm{BC}$, during the second Tapestransgression peak. The area near the outlet of the river is inundated as well as the area between Grudavatn and Skadsvatn. Dark blue $=$ the North Sea, light blue = lakes, yellow $=$ sand drift, arrows $=$ drainage, dotted line $=$ beach ridge system. Drawing: L. Prøsch-Danielsen \& $K$. Eilertsen, AM, UiS. 


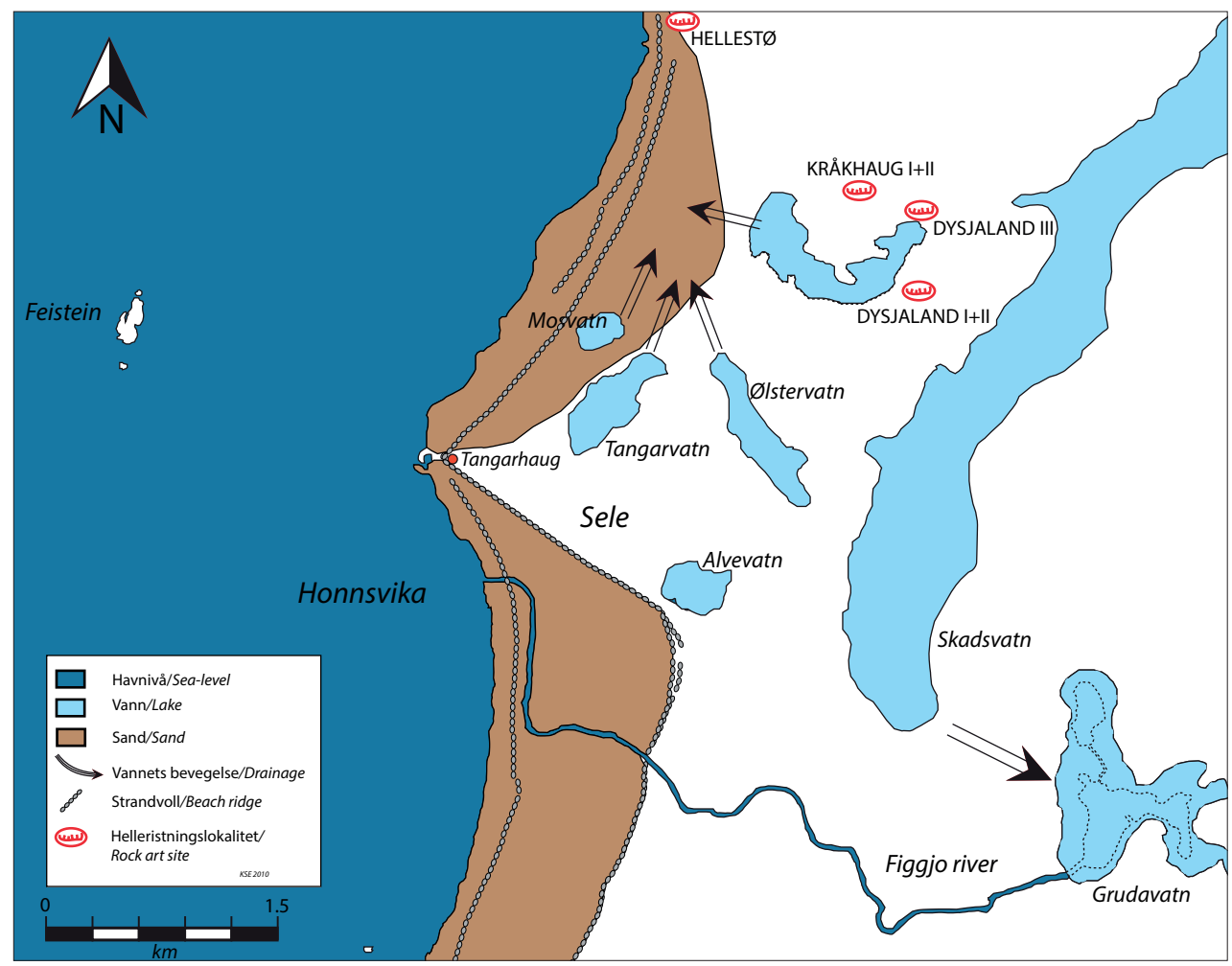

Fig. 35c. Landskapet mellom Hellestø og utløpet av Figgjoelva gjennom bronsealderen 1700 f.Kr. til 500 f.Kr. Grudavatn og Skadsvatn er på ny isolerte fra havet, men er fremdeles gode ferdselsårer mellom havet i vest og indre deler av Sandnes i øst. Kart: L. Prøsch-Danielsen \& K. Eilertsen, AM, UiS.

Fig. 35c. The landscape between the rock art site Hellestø in the north and the river Figgjo in the south throughout the Bronze Age 1700-500 BC. The lakes Grudavatn and Skadsvatn are from now on isolated from the sea. However they still serve as traffic arteries between the sea in the west and the inner parts of Sandnes in the east. Dark blue $=$ the North Sea, light blue $=$ lakes, yellow $=$ sand drift, arrows $=$ drainage, dotted line $=$ beach ridge system, ship figure $=$ localization of rock carving. Drawing: L. Prøsch-Danielsen \& K. Eilertsen, AM, UiS.

til 3200 f.Kr. i sedimentene fra Ølstervatn. Strandvollene som bygde seg opp i sluttfasen av transgresjonen ble liggende bare et par meter under den eldste strandvollen slik at det utviklet seg et bredt strandvollsystem langs denne kyststripa. Fra 4000 f.Kr. hevet landet seg raskere enn havstigningen, slik at strandlinjen fra da av krøp jevnt nedover til dagens nivå (Fig. 35d).
Det betyr at menneskene som holdt til på Dysjaland I, II, III og på «Kråkhaug» i bronsealderen kunne skue utover et haugete, kupert landskap med store arealer dekket av vann; i øst Skadsvatnet opptil 10-meterskoten og i vest Harvalandsvatnet som også var «demmet» opp til 10-meters koten i dette tidsrommet. Mellom Harvalandsvatnet og havet lå det nesten $1000 \mathrm{~m}$ med

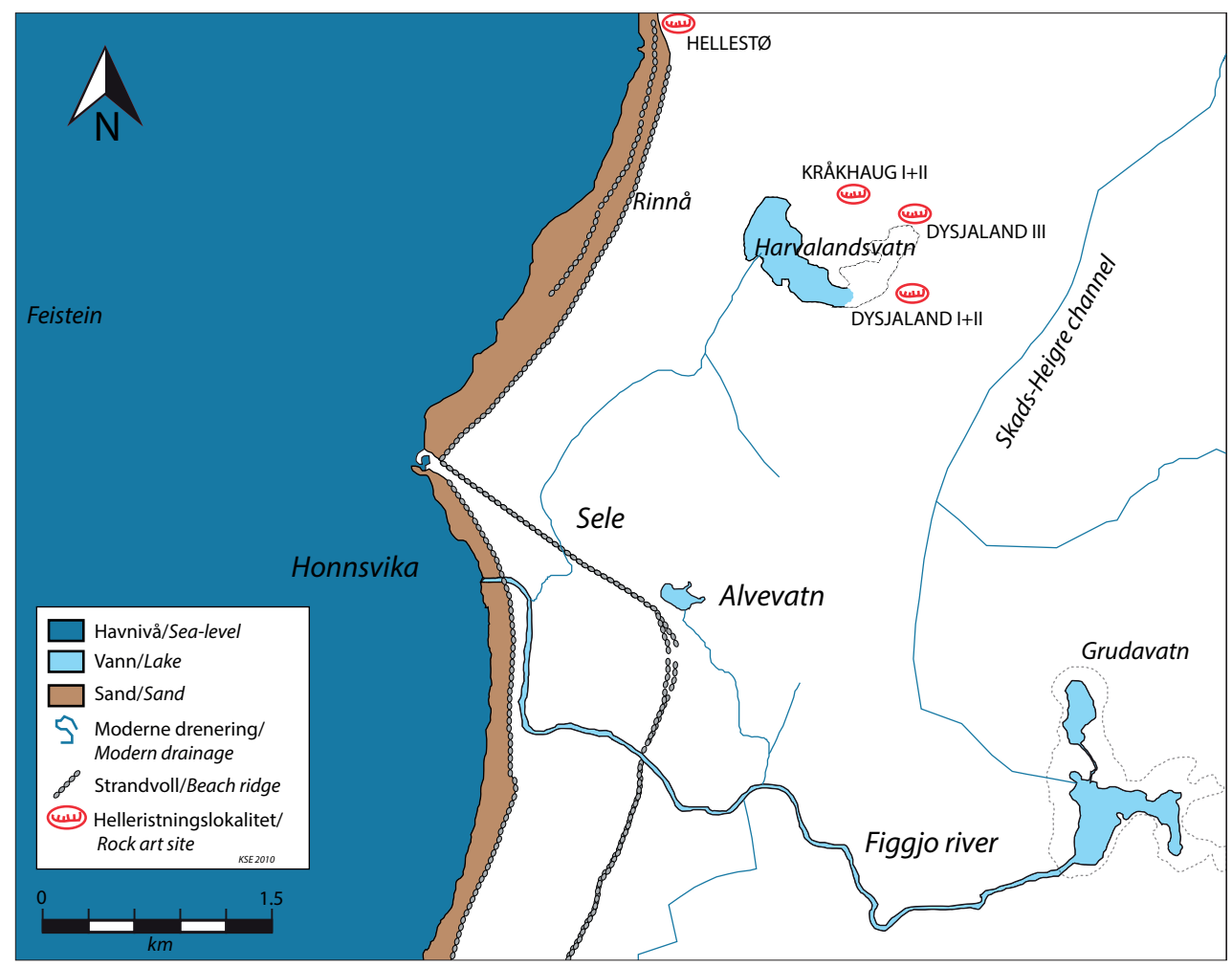

Fig. 35d. Landskapet mellom Hellestø og utløpet av Figgjoelva i dag. Mosvatn, Tangarvatn, Ølstervatn, Skadsvatn og delvis Harvalandsvatn og Alvevatn har blitt drenerte og uttappete. Bergkunstlokalitetene har tapt sin landskapskontekst.

Kart: L. Prøsch-Danielsen \& K. Eilertsen AM, UiS.

Fig. 35d. The landscape between the rock art site Hellestø in the north and the river Figgjo in the south at present. Several of the lakes have been totally or partly drained and the context of the rock art sites can no longer be understood in the landscape. Dark blue $=$ the North Sea, light blue = lakes, yellow $=$ sand drift, dotted line $=$ beach ridge system, ship figure = localization of rock carving. Drawing: $L$. Prosch-Danielsen \& K. Eilertsen, AM, UiS. 
flyvesand og strandsedimenter. Det var bare om lag 500 m mellom Harvalandsvatn og Skadsvatn over eidet ved Dysjaland III. I bronsealderen må det m.a.o. ha vært enkelt å forflytte seg ved hjelp av vannveiene innover jærlandskapet.

Havnivåndringene har, med unntak av ristningene ved Hellestø og Vigdel, ikke hatt noen direkte betydning for lokaliseringen av bergkunstlokalitetene på MidtJæren, men indirekte har endringene påvirket jordbunnsforholdene og gitt opphav til rike jordbruksområder - områdene i Klepp der vi i dag finner bergkunstlokaliteter hovedsakelig enten på løsblokker eller i rike graver med ornamenterte heller. I tillegg førte regresjonen til at store områder ble næringsrike og "ferdig bearbeidet" til jordbruksformål i siste del av neolitikum og inn i bronsealderen. Flere arkeologer har påpekt at nettopp dette området har vært det tettest befolkede området på Jæren fra mesolitikum til et stykke ut i bronsealderen (Gjessing, 1920; Møllerop, 1989). Dette fordi det ble dannet store gruntvannsområder i mesolitikum og tidlig-neolitikum som dermed ga næringsrikt jordsmonn videre inn i seinneolitikum og bronsealder. Mange av Norges tidlige bronsealdersfunn er gjort nettopp i Klepp kommune, noe som speiler viktigheten av dette området på den tiden (Møllerop, 1989).

\subsection{Skålgroplokaliteter}

\section{Tjora, gnr. 10, bnr. 27, Id 65834}

Lokaliteten som ble registrert i 1976 besto av ti runde, klart markerte skålgroper hogd i fast fjell innenfor $2,2 \mathrm{x}$ $1,2 \mathrm{~m}, \mathrm{og}$ lå mot sjøen i nordvestre kant av et nordvestgående berg. Den ble ikke gjenfunnet ved kontroll i 1991 (Haavaldsen, 1991) eller i 2018. Området der skålgropene skal ha ligget, er i dag et utbygd havneområde med asfalterte flater og er derfor høyst sannsynlig sprengt vekk. Da beliggenheten var nær sjøen, gropenes diameteren mellom 10 og $21 \mathrm{~cm}$ og dybden mellom 2,5 og $10 \mathrm{~cm}$, er det meget mulig at dette var små jettegryter.

\section{Rott, gnr. 12, bnr. 1, 2, 5 , Id 54300}

Innenfor et fornminneområde med hustufter, gardfar og rundrøys, registrert i 1969, finnes en skålgropstein, 1,5 m lang, 0,8-1 m brei og 0,5 m tykk. På flatsiden som ligger framme i dagen er det åtte til ti skålgroper med diameter mellom 4 og 8 cm (Bang-Andersen, 1982a).

Håland, gnr. 21, bnr. 1, 2, 6, Id 65848

Innenfor et fornminneområde med gårdsanlegg, gravhauger, rydningsrøyser og åkerrein er det på ei stor jordfast blokk hogd inn ei skålgrop på oversiden av steinen. Skålgropas diameter er $5 \mathrm{~cm}$ og dybden $1,5 \mathrm{~cm}$. Lokaliteten ble sist ØK-registrert i 1991 (Trøim \& Henriksen, 1991c).

\section{Håland, gnr. 21, bnr. 1, 2, Id 44550}

Innenfor et fornminneområde med gravhaug og hustuft er det på ei 2 x 3 m stor flate, på ei jordfast blokk, hogd inn mange skålgroper hvor diameteren er mellom 3 og 5 $\mathrm{cm}$, og en dybde mellom 1 og $2 \mathrm{~cm}$. Området er forstyrret av tysk aktivitet under 2 . verdenskrig. Lokaliteten ble sist ØK-registrert i 1991 (Trøim \& Henriksen, 1991d).

Håland, gnr. 21, bnr. 1, 2, 214, Id 72350

Lokaliteten som består av to ringfigurer på en større flat blokk samt ei skålgrop på en større jordfast blokk, $10 \mathrm{~m}$ øst for denne, ble registrert i 1985 (Hemdorff, 1985). Ved nærmere ettersyn er de to ristningene antakelig grensemerker, og gropa er naturlig.

\section{Hellestø, gnr. 24, bnr. 14, 22, Id 54309}

Ei skålgrop med diameter på $7 \mathrm{~cm}$ og dybde $2 \mathrm{~cm}$ som i 1968 ble registrert på et svaberg, ble ikke gjenfunnet ved kontroll i 1991 (Trøim \& Henriksen 1991e). Ved befaring i 2018 ble det konstatert at gropa må ha blitt sprengt vekk i forbindelse med bygging av garasje. Fornminnet er nå slettet i Askeladden.

Tjelta, gnr. 28, bnr. 18, 87, Id 44557

Innenfor et fornminneområde med to gravhauger er det på ei jordfast blokk hogd inn ca. sju sikre runde skålgroper samt ei oval grop. Gropene som er klart markerte, har en diameter på inntil $10 \mathrm{~cm}$ og dybde inntil $4 \mathrm{~cm}$. Den ovale gropa er $4 \mathrm{~cm}$ lang og $2 \mathrm{~cm}$ dyp, og ble sist ØK-registrert i 1991 (Trøim \& Henriksen, 1991e).

\section{Tjelta, gnr. 28, bnr. 28, Id 5530}

Lokaliteten ligger på en flate på en bergrygg inne på et gardstun. Seks til sju groper er synlige og i god stand. Det kan finnes flere da flaten er bevokst med gras og lyng. Lokaliteten ble sist ØK-registrert i 1991 (Trøim \& Henriksen, 1991f).

\section{Gimra, gnr 29}

I en artikkel i Stavanger Museums årbok skriver B. Myhre (1964, s. 14) at på Gimra finnes et lite felt med 10 til 15 skålgroper på en sørvendt bergflate som nylig ble oppdaget ved registreringsarbeid og som ennå ikke er nærmere undersøkt. Det finnes hverken opplysninger i topografisk arkiv om seinere registrering, eller kartavmerking, av lokaliteten. 


\subsection{Løse heller og blokker med ristninger og skålgroper}

Litle Meland, «Ausebakken», gnr. 2, bnr. 5, S10130

Skålgropsteinen som har 32 groper hvorav 22 på den ene og 10-11 på den andre siden, ble funnet i 1977 i oppgravde masser fra ei kloakkgrøft på nordsiden av huset.

\section{Myklebust, gnr. 3, S269-S271, Id 24650}

Hellene stammer fra en haug med kjernerøys, undersøkt i 1878. S269 som består av tre par fotsåler og 12 groper, er en av veggene i et lite gravkammer som ble funnet lengst sør i haugen der ristningene var vendt innover mot gravkammeret. Leirkarskår, S1283, skal være funnet i kammeret. På hella S270 er det elleve groper, i tillegg er det et hull tvers gjennom hella, mens S271 består av fire groper, begge ble funnet i rullesteinene i kjernerøysa. Det er uvisst om hellene skal dateres til eldre eller yngre bronsealder, se for øvrig Syvertsens vurderinger (2003, s. 155).

\section{Haga, gnr. 6, S946}

Ristningshelle med to skipsfigurer samt 26 groper (Fig. 36). Hella er sprengt ut av blokk og funnet like ved Hafrsfjord i 1879. Ristningene antyder en datering til eldre bronsealder.

\section{Nord Kolnes, gnr. 11, S6656a og 6656b}

Hellene er funnet i en graskledt rundhaug som var sterkt ødelagt, etterundersøkt i 1937 da det ble påvist et om lag $4 \mathrm{~m}$ langt gravkammer. Hellene og ei hestetann ble imidlertid funnet i jordhaugene i 1939. S6656a består av en skadet grop i ene hjørne, S6656b av en grop på hver side av hella. Haugen, og dermed hellene, dateres av B. Myhre muligens til eldre bronsealder (B. Myhre, 1981, s. 175).

\section{Sola, gnr. 14, S9783}

Ristningshelle med en dyrefigur. Funnet i steinfylling på flyplassen. Muligens har massene kommet fra Ølberg eller Sola (B. Myhre, 1981, s. 99). Det er vanskelig å avgjøre om figuren er et hjortedyr eller ku/okse, og av den grunn er dateringen uviss.

\section{Rægje, gnr. 17, bnr. 2, Id 72347}

I en restaurert haug med kjernerøys finnes ei ristningshelle med seks figurer; tre groper, en konsentrisk ringfigur som består av tre ringer, en spiral, en ubestemmelig vertikal figur samt tre huggmerker. Hella dateres til eldre bronsealder periode II (Syvertsen, 2003, s. 156).

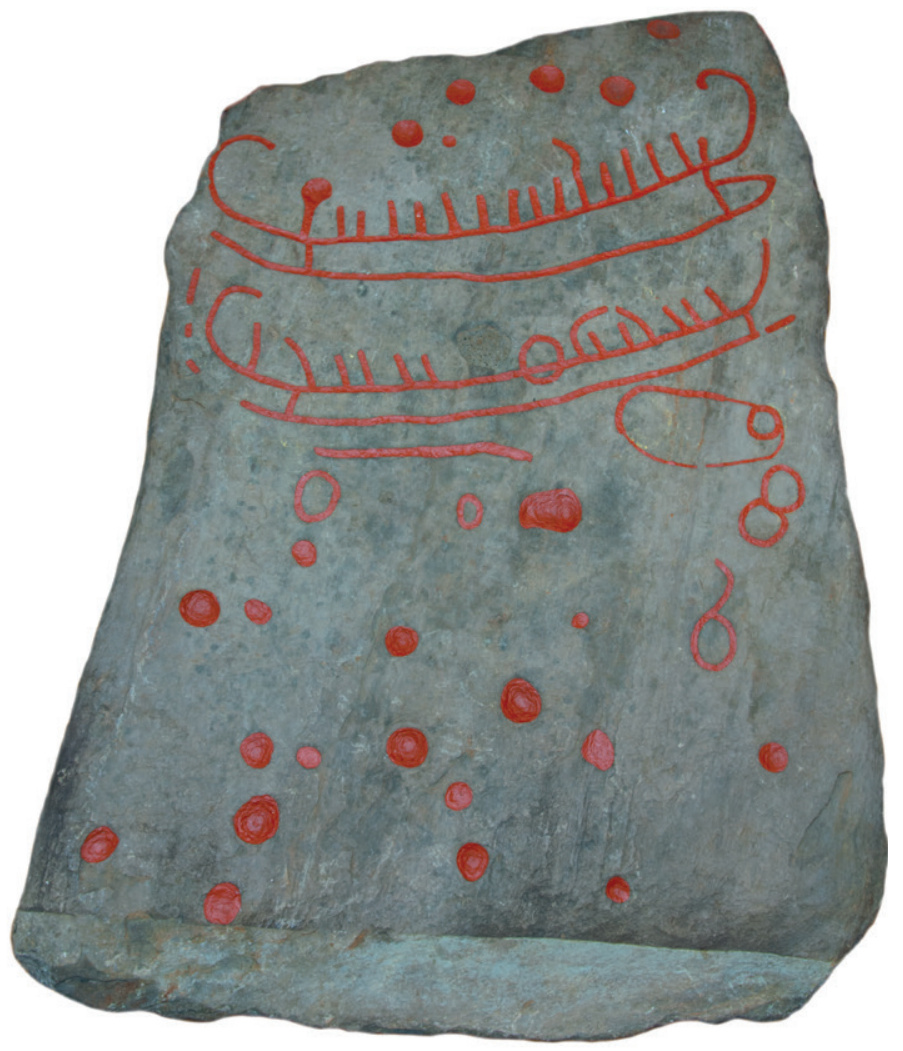

Fig. 36. S946. Helle med ristninger funnet på Haga i Sola. Foto: T. Tveit, AM, UiS.

Fig. 36. S946. An ornamented slab from Haga in Sola. Photo: T. Tveit, AM, UiS.

\section{Rægje gnr. 17, bnr. 57, S11921, Id 44544}

S11921 var bunnhella i et kammer funnet i haug og består av tre enlinjete skipsfigurer, en med mulige mannskapsstreker, fire mulige fotsåler og sju groper hugget på den ene siden, på den andre 15 runde og ovale groper. Hella dateres til eldre bronsealder, muligens periode II. (Syvertsen, 2003, s. 57).

Rægje, gnr. 17, bnr. 57, S6502 og tapt grophelle, UM, Bergen

Funnene utgjør to gropheller samt ett grophellefragment. De skal visstnok stamme fra ovennevnte haug, Id 44544.

\section{Rægje, gnr. 17, bnr. 2, S9455}

Ei helle med 17 groper ble i 1969 funnet i en steingard ikke langt fra gravhaug «Engjehaugen» (id 24675).

\section{Harvaland, gnr. 26, S6472}

Ristningshelle med to skipsfigurer med mannskapsstreker samt «sirkelfigur» over skipene. Funnet på en høyde i 1937 like øst for den vestligste av Harvalandsgårdene. 


\section{Klepp kommune}

\section{I Bergkunst- og skålgroplokaliteter}

\author{
Særheim, gnr. 15, 16, bnr. 14, Id 5288 \\ Historikk, beliggenhet og presentasjon av lokalitet og
} figurer

I forbindelse med utgraving av «Steinhaug», i perioden 1969 til 1971 (Bertelsen, 1970), ble det påtruffet en rekke gropheller og gropsteiner (se også Syvertsen, 2003, s. 152-154) samt tre jordfaste blokker under røysa; ei med to fotsåler samt to med seks groper hver. Røysa ligger på et av de høyeste partiene i Klepp kommune, 95 moh.

\section{Datering}

Røysa hadde vært utsatt for flere inngrep og skader før undersøkelsen tok til. I røysa er det funn fra seinneolitikum (røysa er antakelig anlagt på eldre boplass) til eldre jernalder. Pga. omroting og mangel på funn som kan indikere alderen på de sentrale delene av anlegget, er det vanskelig å datere røysas etableringstidspunkt. Datering fra fem kullgroper og askelag innenfor den innerste steinrekka ga 2600 til 2300 BP, dvs. overgangen yngre bronsealder/eldre jernalder. Dette indikerer at ristningene må være eldre enn eldre jernalder.

\section{Bergart, geologisk vitring og slitasje}

Flyttblokkene består av lys gneis, med innslag av glimmerskifer (Provan, 1974). Glimmerskifer er en bergart som er forholdsvis bløt og som lett forvitrer. Gropene er hogget i partiene med glimmerskifer. Det ble derfor bestemt at en skulle utføre forsøk med overflateimpregnering av de to flyttblokkene med skålgroper. Hensikten var å vinne erfaring som evt. kunne brukes på andre bergkunstfelt. Selve gropene ble ikke påført midler. Blokkene ble delt inn i felt hver med bredde på $30 \mathrm{~cm}$, annenhver var ubehandlet, mens de øvrige ble påført seks ulike midler. Forsøket startet i 1971 og ble fulgt opp 1972 og 1973 av Provan (1974), av Mauritzen i 1974 (1974) og Sømme Dahl i 1976 og 1979 (1976, 1979). Dahl konkluderer i 1979 med at ved bruk av Crystic $257+2 \%$ Celestite er det atskillig mindre lav og alger enn på de ubehandlete feltene. Overflata var frisk og uforvitret. I 2013 var det ingen forskjell å se.

\section{Endring over tid og skader påført av mennesker}

Ved befaring i 2013 var det vanskelig å se noen endringer sammenlignet med rapportene fra 1970-tallet. Det er ikke påvist hærverk eller lignende. Rogaland fylkeskommune har i de seinere årene lagt ned betydelig arbeid i skjøtsel og inngjerding av området, og Arkeologisk museum, UiS, restaurerte selve gravminnet i 2014 (Gil, 2017).

Hauge, gnr. 19, lokaliteten mangler Id-nummer.

Lokaliteten er en jordfast skålgropstein. Steinen er omtalt i E. Fett og P. Fett (1941, s. 95), men det opplyses ikke hvem som har påvist lokaliteten.

Skålgropsteinen er ujevn, knudret og isprengt kvartsårer. Den ligger $100 \mathrm{~m}$ sørvest for gården midt i en bakkeskråning. På toppen er det sju groper, andre steder på steinene finnes flere groper. Disse er ifølge E. Fett og P. Fett mest sannsynlig naturlige (1941, s. 95). Lokaliteten er ikke registrert i Askeladden.

\section{Håland gnr. 23, bnr. 2, Id 219216}

Historikk, beliggenhet og presentasjon av lokalitet og figurer

Lokaliteten besto av tre felt hvorav felt I ble påvist i 1919 og felt II og III av E. Fett og P. Fett i 1933 (E. Fett \& P. Fett, 1941, s. 87). Felt I lå på en stor jordfast blokk ved nordre hjørne av det tidligere kårhuset (nå revet) på bruket (jf. pl. 71 A-C i E. Fett \& P. Fett, 1941). Den er nå sprengt bort. Felt II ligger lenger vest på en lang bergrygg i retning VSV-ØNØ der gropene ligger i sørvestre hjørne. Felt III ligger ca. 20 m sørøst for felt I på en knaus som faller bratt mot sør.

Felt I besto av 78 groper, og flere linjer som ifølge E. Fett og P. Fett (1941, s. 87) kan tolkes som én skipsfigur (Fig. 37). Felt II består av 42 groper som alle ligger tett samlet. I nord er bredden $35 \mathrm{~cm}$, i sør $12 \mathrm{~cm}$, og lengden fra nordligste til sørligste grop er $55 \mathrm{~cm}$. Ved fotografering i 2014 framkom et sikkert skip $(38 \mathrm{~cm}$ fra stavn til stavn) samt ett mulig skip nedenfor gropene på felt II (se Fig. 38), mens på felt III finnes to sikre groper som ligger $15 \mathrm{~cm}$ fra hverandre og en mer tvilsom grop om lag $10 \mathrm{~cm}$ nord for den østre.

På fjellryggen øst for felt II er det flere mulige skålgroper, i alt fire grupper med til sammen 15 groper. Fem groper ble også observert av E. Fett og P. Fett. Disse ble den gang ikke registrert fordi de lå spredt, men forfatterne påpeker at «de ser regelmessige ut og kan være hugget» (1941, s. 88). 
Fig. 37. Bergkunsten på Håland, felt I og II i Klepp (E. Fett \& P. Fett, 194I, pl. 4I B og A). Fig. 37. The rock carvings at Håland panel I and II in Klepp (E. Fett \& P. Fett, 194I, pl. B and A respectively).

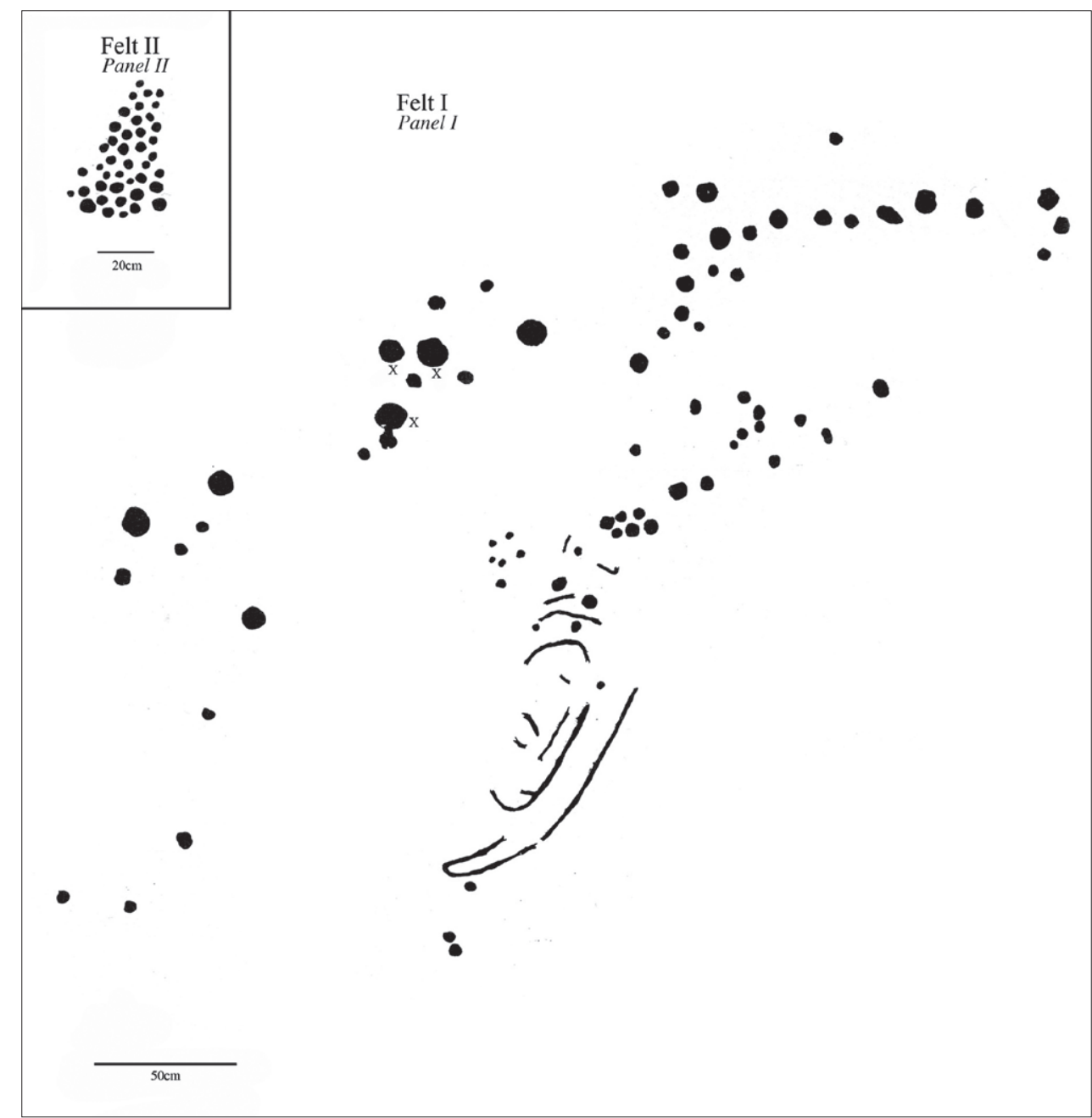

det seiler mot venstre. Gropenes spredning ut over flyttblokka kan minne om en stjernehimmel, og tre av gropene var ekstra dype (Fig. 37, felt I, merket med X). Også felt II er spesielt med 42 groper tett i tett innenfor et begrenset areal. Skipet nedenfor kan karakteriseres som et B3-skip (Mandt, 1991, s. 47) og dateres fra periode III til

Fig. 38. Skålgroper på felt II, Håland. Foto: A. Pedersen, AM, UiS.

Fig. 38. Cup marks at field II, Håland. Photo: Å. Pedersen, AM, UiS.

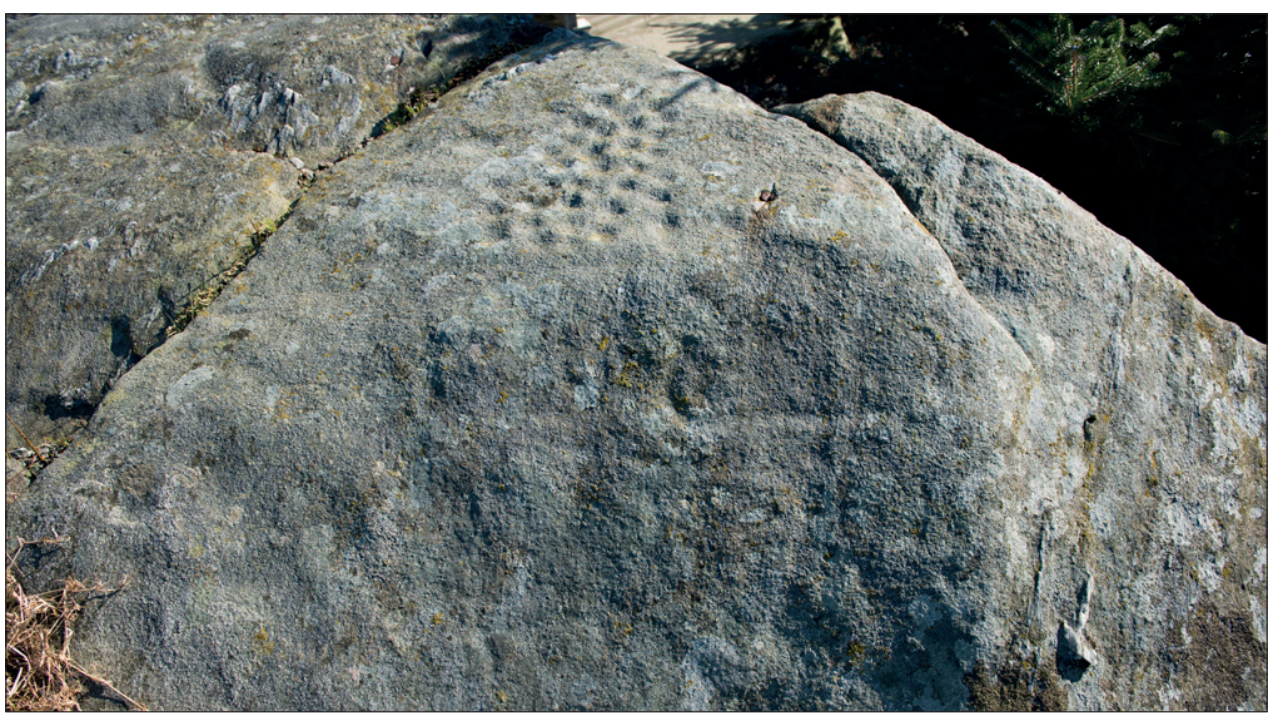


V, dvs. fortrinnsvis yngre bronsealder (Wrigglesworth, 2011, s. 118).

\section{Bergart, geologisk vitring og slitasje}

Lokaliteten er ikke undersøkt av geolog, men E. Fett og P. Fett (1941, s. 87) karakteriserer bergarten på felt I som «knudrete og hard og full av naturlige ujevnheter». De påpeker at alle de hogde linjene er svake, og at det således kan ha vært flere linjer. Likeledes er bergarten på feltene II og III beskrevet på samme måte. Alle de hogde linjene på felt I var ifølge E. Fett og P. Fett (1941, s. 87) ytterst svake, og som det framgår av Fig. 37 ser en at flere linjer må ha blitt vitret bort. Når det gjelder felt II er gropene grunne, men regelmessige, mens gropene på felt III er forholdsvis dype.

\section{Endringer over tid og skader påført av mennesker}

Felt I ble sprengt vekk i 1965. Feltene II og III er fortsatt intakte og det har ikke skjedd endringer her etter 1933.

\subsection{Løse heller og blokker med ristninger og skålgroper}

\section{Gruda, gnr. 3, S5160}

Flat, ujevn stein med seks groper ble funnet ved ei kjellertrapp.

\section{Anda, gnr. 14}

Ei nå tapt grophelle, hvor det skal ha vært hugget groper på den ene siden, skal ha blitt funnet i en haug sammen med ei grov keramikkurne. Hella dateres til bronsealder (Syvertsen, 2003, s. 146).

\section{Anda, gnr. 14}

En nå tapt ristningshelle tolket som «ristning av ornamentale linjer» ble funnet $\mathrm{i}$ et kammer $\mathrm{i}$ en rundhaug. Motivene og kammertilknytning indikerer en datering til eldre bronsealder (Syvertsen, 2003, s. 146).

\section{Særheim, gnr. 16, bnr. 1, S9633aq}

12 gropheller og -steiner, med alt fra en til elleve groper på hver, ble funnet under utgraving av Steinhaug, en stor haug på 30-40 x 2 m med seks steinrekker og flere graver, men der bare den sørlige delen av haugen er undersøkt. Ei helle ble funnet i en av murene, de øvrige i haugfyllen innenfor et avgrenset område.

Trekulldateringer samt gjenstandsmaterialet, gir datering til eldre jernalder. Det er imidlertid mulig at det kan ha vært eldre begravelser i haugen. Dateringen av grophellene og -steinene er imidlertid uviss (Syvertsen, 2003, s. 152-154). Inne i haugen var det i tillegg tre jordfaste steiner hvorav to med groper og en med to fotsåler (se omtale under id 5288).

\section{Tu, gnr. 17, bnr. 3, S8678}

Helle med tre store groper i midten og fire små rundt ble funnet i steingard i 1960. Tre av de små gropene er ødelagte fordi hella er brukket.

Tjøtta, gnr. 18, bnr. 68, B4894, Id 44334

Stein med om lag 35 groper skal ha blitt funnet i muren ved hodeenden til et oppmurt gravkammer der gropene var vendt inn mot kammeret i haugen. Gjenstander fra kammeret dateres til folkevandringstid. Gropsteinen er ikke en ordinær gravhelle. Den var så pass tung at en sprengte av overflaten med gropene for å få steinen med seg til Bergen Museum. Steinen kan derfor være eldre enn grava, dateringa er av den grunn usikker (Syvertsen, 2003, s. 154).

\section{Nord Braut, Sør Braut, gnr. 20, 21, S5700}

Stein med fem runde groper rundt ei stor oval grop i midten, ble funnet på et jorde i 1930. Det er ikke registrert gravhauger i nærheten.

\section{Sørbø Nedre, gnr. 23, S5111}

En flat stein med to groper ble funnet i 1929 ved et gjerde like ved prestegården.

\section{Sørbø Nedre, gnr. 23}

Helle med tre groper fantes øverst i en steingard sørvest for Klepp kirke. Hella er tapt (E. Fett \& P. Fett, 1941, s. 88).

\section{Nese, gnr. 25, bnr. 5, 8, S9785}

Stor grop- og ristningsstein med ei dyp grop, elleve mindre og grunnere groper, en stiplet sirkel og ei dyp $5,1 \mathrm{~cm}$ lang renne som vider seg ut i den ene enden, og tolkes som en arm med mulig hånd med finger/tommel. Funnet i 1971 like inntil en stor, men ødelagt gravhaug fra bronsealder (id 24479). Syvertsen daterer steinen til bronsealder (Syvertsen, 2003, s. 152).

\section{Nedre Horpestad, gnr. 28, S3411}

En stein med 17 groper, hvorav 12 på den ene og fem på den andre siden, ble funnet i en steingard i 1916.

\section{Erga, gnr. 30, S4555}

Helle med to groper, en på hver side, ble i 1924 funnet i en haug med gjenstander fra flere perioder. Dateringen er derfor uviss. Fra en annen, nå fjernet langhaug, på Erga (bnr. 10, id 14656) skal det ha blitt funnet flere heller med groper som stammer fra ei kammergrav. 
Hellene kan være fra eldre bronsealder, men gjenbrukt i folkevandringstid (Syvertsen, 2003, s. 150).

\section{Reve, gnr. 41, S38461}

Mulig skålgropstein som på den ene breisida har en utilhogget skålformet fordypning. Funnet i 1918 i ei hustuft datert til førromersk jernalder.

\section{Hodne, gnr. 42, bnr. 5, S3506}

Ristningshelle med fem konsentriske linjer over tre parallelle vinkellinjer og en horisontal linje (Fig. 39), funnet i 1911. Syvertsen (2003, s. 151) daterer hella til eldre bronsealder ut fra ristningsmotivet og opplysninger om at hella skal stamme fra et kammer i en haug, muligens Håhaugen (id 65563).

\section{Hodne, gnr. 42, bnr. 7, S4158}

Ristningshelle med fire konsentriske linjer, funnet i en haug med kammer i 1920. I kammeret ble det funnet bronsesverd og håndleddsring av gull, datert til eldre bronsealder periode III. Hella må rimeligvis være samtidig (Syvertsen, 2003, s. 151).

\section{Borsheim, gnr. 43, bnr. 2, B5611}

Ristningshelle med $25 \mathrm{~cm}$ bredt ornamentbånd, avgrenset av to horisontale linjer og løpende spiral mellom linjene, ble funnet i forbindelse med G. Gustafsons delvise utgraving av Stavhaug (id 54135). Hella ble funnet som en av «flere rundt om sentrum plasserte heller».

Fig. 39. S3506. Ornamentert gravhelle funnet på Hodne. Foto: T. Tveit, AM, UiS. Fig. 39. S3506. An ornamented slab found at Hodne. Photo: T. Tveit, AM, UiS.

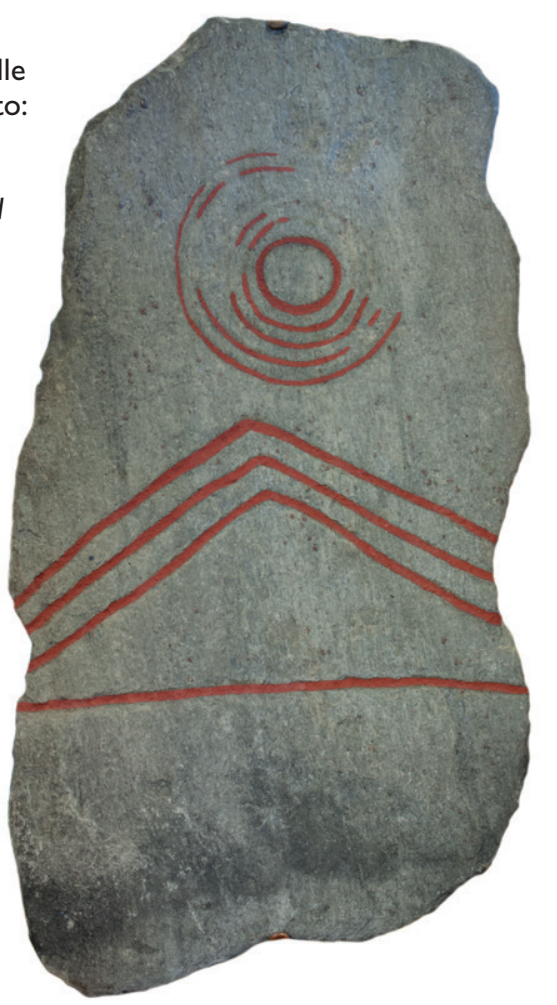

Syvertsen (2003, s. 149) daterer hella til eldre bronsealder ut fra funnomstendigheter og ornamentikk (jf. de Lange, 1913, s. 26).

\section{Borsheim, gnr. 43, bnr. 2, S4036a og b}

Hellene med henholdsvis fire og to groper, innbrakt til museet i 1918, kan stamme enten fra Stavhaug (id 54135) eller en rundhaug fjernet i 1880-åra kalt Rudla. Syvertsen (2003, s. 149) argumenterer for at dateringen muligens er eldre bronsealder.

\section{Austre Bore, gnr. 45, S6020m}

Grophella ble funnet i 1933 i bunnen av ei røys, Molkhaug (20 x 1,8 m) (Egenæs Lund, 1934).

Hella har 28 groper hugget på en side, funnet som nederste dekkhelle av to. De lå over et anlegg med fire heller horisontalt plassert $\mathrm{i}$ en ring. Bunnen i rommet var dekket med trekullrester og mørkbrent jord. Oppå dette laget lå en skinnende hvit rullestein. Alle hellene var mørkbrente unntatt dekkehella med groper (vendt mot rommet) og den hvite steinen. Anlegget kan tolkes som rester etter rituell bruk av ild i forbindelse med to kammergravnedleggelser i røysa. «Ildstedet» og kamrene må være noenlunde samtidige da alle tre var lagt på aurbakken under røysas sentrum. Ut fra funn i det ene kammeret kan hella dateres til eldre bronsealder, periode II/III (Syvertsen, 2003, s. 147).

\section{Austre Bore, gnr. 45, S6143}

Helle (nå i to deler) med to groper ble funnet da bonden i 1933 fjernet restene av Molkhaug. Kan dateres til eldre bronsealder, dvs. samtidig med røysa (Syvertsen, 2003, s. 148).

\section{Austre Bore, gnr. 45, S6655}

Helle med 32 groper funnet i 1937 som sluttstein i en jordkjeller, bygd i en gravhaug (Storhaug) hvor det tidligere var gjort funn fra yngre bronsealder; bruddstykker av urne fylt med brente bein, bronsepinsett og deler av en knapp (S1389) sto i østre ende av et mannslangt kammer. Muligens er urna en gjenbegravelse i et eldre kammer. Syvertsen forslår derfor en datering av hella til eldre bronsealder, jfr. S6020, men hun holder også muligheten åpen for en yngre datering (Syvertsen, 2003, s. 148, se også E. Fett \& P. Fett 1941, s. 86).

\section{Austre Bore, gnr. 45, bnr. 5}

Ei helle med fem groper lå ved E. og P. Fett sin registrering i 1937 (E. Fett \& P. Fett, 1941, s. 87) i veggen i en jordkjeller. I motsetning til S6655 var det ikke mulig å ta den ut av veggen (se også Syvertsen, 2003, s. 164). 


\section{Time kommune}

\section{I Løse heller og blokker med ristninger og skålgroper}

\section{Re, gnr. 3, B4820d}

Vegghelle med fem groper på den ene siden, vendt innover i et kammer som var plassert midt i en terrasseformet haug, ble funnet ved undersøkelse av haugen i 1891 av G. Gustafson. Grov uornert keramikk skal være funnet i og ved kammeret, blykors og brynestein i haugfyllen. Syvertsen (2003, s. 144) mener haugens form kombinert med kammer, helle og groper som er vendt innover, indikerer eldre bronsealder.

\section{Re, gnr. 3, S5035d, S5035e, S5066g}

Heller og stein med groper funnet i 1938 i langrøys. Da det er gjort funn fra flere perioder i røysa (som også kan være påbygd), er det vanskelig å gi en eksakt datering (Syvertsen, 2003, s. 145).

\section{Re, gnr. 3}

Ei nå tapt helle med ei grop var brukt som dekkhelle i kammer i haug undersøkt av G. Gustafson. Gropa vendte nedover. I kammeret ble det funnet en dolk av bronse (B5002) datert til eldre bronsealder periode III (Syvertsen, 2003, s. 146).

\section{Hognestad, gnr. 9, bnr. 6, S9784}

Helle med to groper der en nærmest er kvadratisk, mens den største er dypere og svært ujevn. Hella var en av de midterste dekkehellene som lå over et $2 \mathrm{~m}$ langt gravkammer i en gravhaug (id 64492). I kammeret ble det bla. funnet en bronsedolk (S6400a), datert til eldre bronsealder periode II (Andersen, 1936). En må anta at grophella er samtidig (Syvertsen, 2003, s. 143-144), Johnsen mener imidlertid at gropene kan være av nyere dato (Johnsen, 1974, s. 102-103).

\section{Auglend, gnr. 10, S2405}

Ristningshelle med parallelle buemønstre mellom parallelle horisontale linjer, mulige parallelle buelinjer ovenog nedenfor feltet. Hella sies å være funnet i en graskledt gravhaug i 1901 hvor det visstnok ikke ble funnet spor etter begravelse (Helliesen, 1901, s. 118-119). Syvertsen mener hella sannsynligvis er fra eldre bronsealder pga. ornamentikken og ingen funn som kan indikere en yngre datering (Syvertsen, 2003, s. 143).

\section{Auglend, gnr. 10}

Helle med sju groper ligger antakelig fortsatt i en steingard (id 44834) (Syvertsen, 2003, s. 164).

\section{Herikstad, gnr. 11, S4745}

Gropstein med to bølgelinjer og fem groper på en side og en på den andre ble levert til museet i 1926. Funnopplysninger mangler. 


\section{Hå kommune}

\section{I Løse heller og blokker med ristninger og skålgroper}

\section{Søyland, gnr. 3, S4452}

Helle med fem parallelle buer over to horisontale linjer, brukt i gavlen i en hellekiste. Figurene vendte innover. Haugen (id 61060) har vært utsatt for plyndring, ingen daterende gjenstander ble funnet, kun noen leirkarskår og kull. Da flertallet av ristningsheller som vender innover i kammeret, dateres til eldre bronsealder, er en datering til denne perioden sannsynlig (Syvertsen, 2003, s. 143).

Motland, gnr. 20, S6725

En stein med tre groper ble levert til museet i 1939. Funnopplysninger mangler.
Nølstad, gnr. 30, S4630h

Stein med åtte groper på en side ble funnet i fyllen i forbindelse med ettergraving i 1925 av et kammer (id 34488) der det bla. ble funnet stangknapp av bronse og flere leirkar, derav to ansiktsurner. Tidligere er det undersøkt nok et kammer der gjenstandene kunne dateres til folkevandringstid (B4889a-g). Syvertsen (2003, s. 142) argumenterer for at en datering av gropsteinen til yngre bronsealder er mest sannsynlig. 


\section{Eigersund kommune}

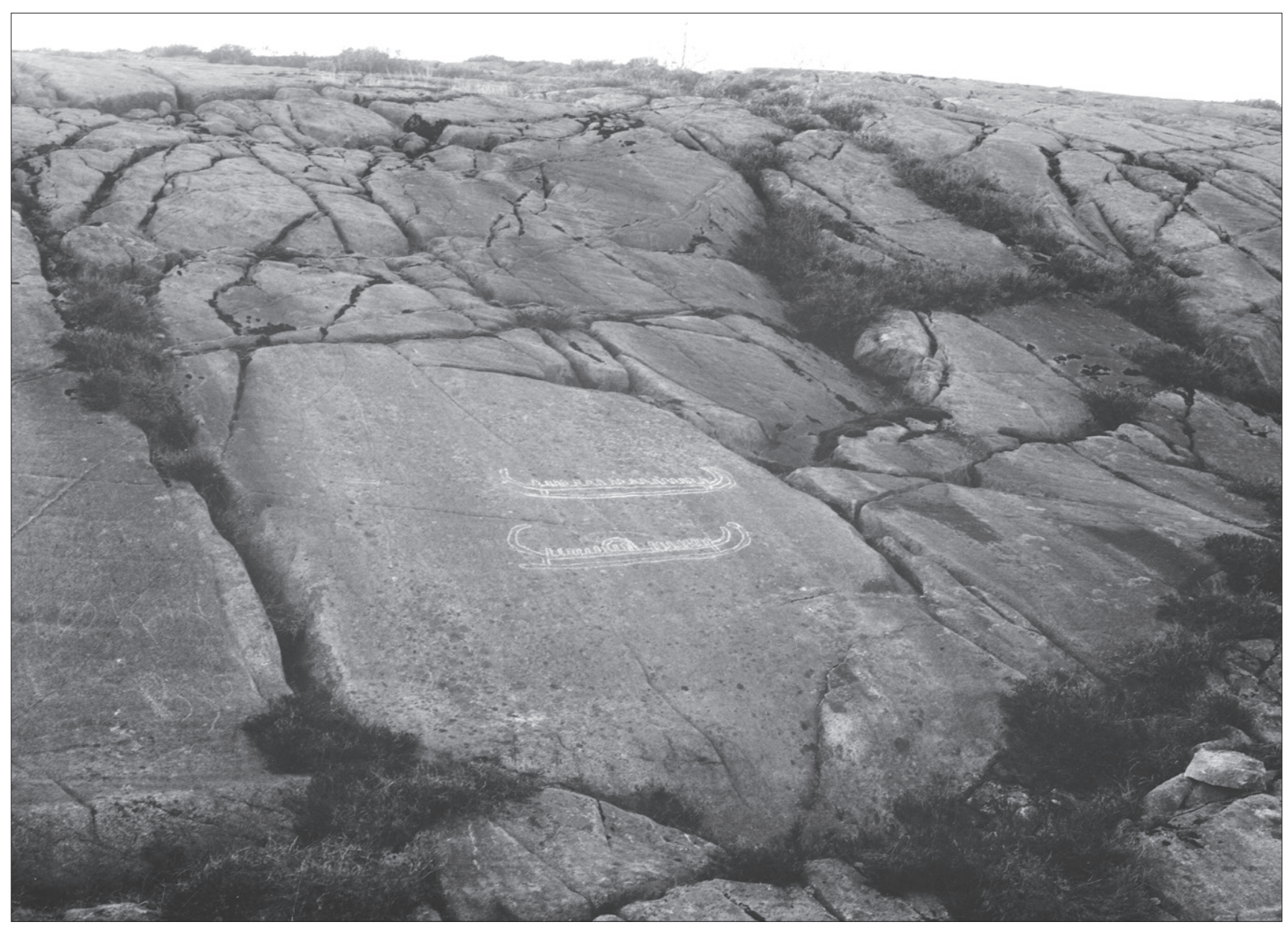

Fig. 40. Figurene på bergveggen på Husabø. Foto: E. og P. Fett (I94I).

Fig. 40. The rock art site at Husabø. Photo: E. and P. Fett (194I).

\section{I Bergkunstlokaliteter}

\section{Husabø, gnr. 12, bnr. 1, Id 71931}

\section{Historikk, beliggenhet og presentasjon av lokalitet og} figurer

Første melding om og undersøkelse av feltet var i 1904 ved pastor Tybring, der han også tegnet figurene (1904). Brøgger undersøkte lokaliteten i 1910 med avtegning på silkepapir (1910b), E. Fett og P. Fett i 1933 (1941, s. 92, pl. 41C) og Eide med kalkering i 1993 (1993).

Lokaliteten ligger på et ØSØ-vendt skrånende berg (hellingen er ca. 50 ) (Fig. 40) om lag $30 \mathrm{~m} \mathrm{NNV}$ for våningshuset på gården og $\mathrm{i}$ dag innenfor et nyere boligområde. Lokaliteten som består av to sikre skip som begge seiler mot høyre (Fig. 41), ligger henholdsvis
1,4 og 1,8 m opp fra foten av fjellet. På skip nr. 1 er det merket av likt antall mannskapsstreker (19) av samtlige fire personer som har avtegnet skipene, men bindelinjene mellom kjøllinje og relingslinje er noe avvikende hos Tybring. Skip nr. 2 har flere detaljer, Brøgger har kun med mannskapsstrekene, mens de øvrige har merket seg to adoranter samt at to av mannskapsstrekene er bundet sammen, tidligere ofte kalt «brudepar» (E. Fett \& P. Fett, 1941, s. 92). Forbindelseslinjen er imidlertid noe usikker, av den grunn er den avmerket med åpen kontur. Eide har også merket seg en svak buet linje som går opp fra den bakre mannskapsstreken, tolket som en mulig lurblåser. Da linjen er svakere enn mannskapsstreken, er også den avtegnet med åpen kontur. Muligens er denne hogget 
Fig. 4I. Kalkering av ristningene på Husabø, etter Eide (1993). Fig. 4I. The traced rock art at Husabø. After Eide (1993).

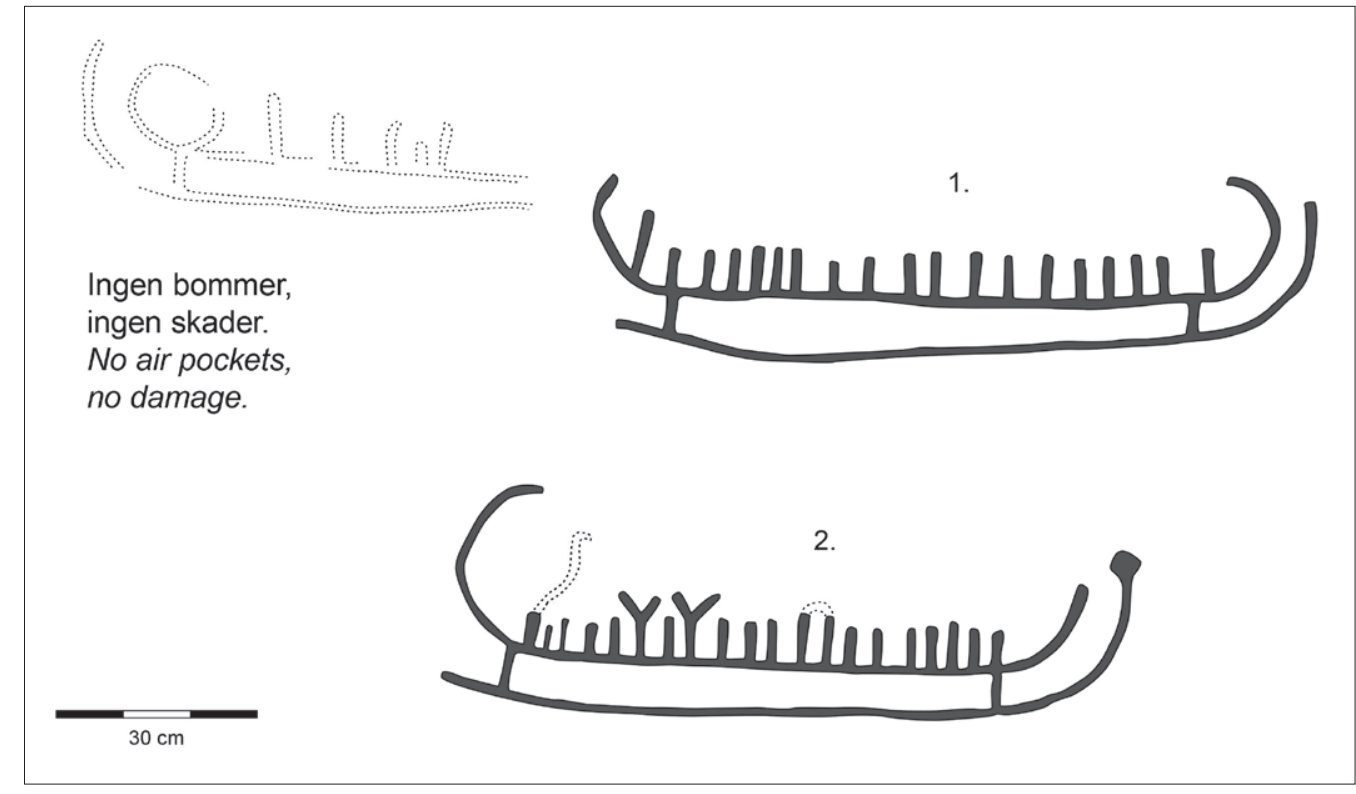

inn på et seinere tidspunkt. I tillegg har han markert et mulig tredje skip som ligger like vest for skip nr. 1. Dette skipet er hogd i $3 / 4$-lengde med solsymbol i stavnen og er aldri blitt fullført. Eide bemerker at selv om «den ikke er komplett og har svake og noe uetterrettelige hoggelinjer, særlig på grunn av opprissingen, har den noen dypere partier i hogglinjene som indikerer at den kan være like gammel og hogd i samme teknikk som de andre to» (Eide, 1993). Han mener dette skipet neppe kan være et falsum og kan således ikke være en av de «nyere skipsfigurer» som E. Fett og P. Fett beskriver lokaliteten er oversådd av. Brøgger skriver imidlertid «det eiendommelige er at jeg,

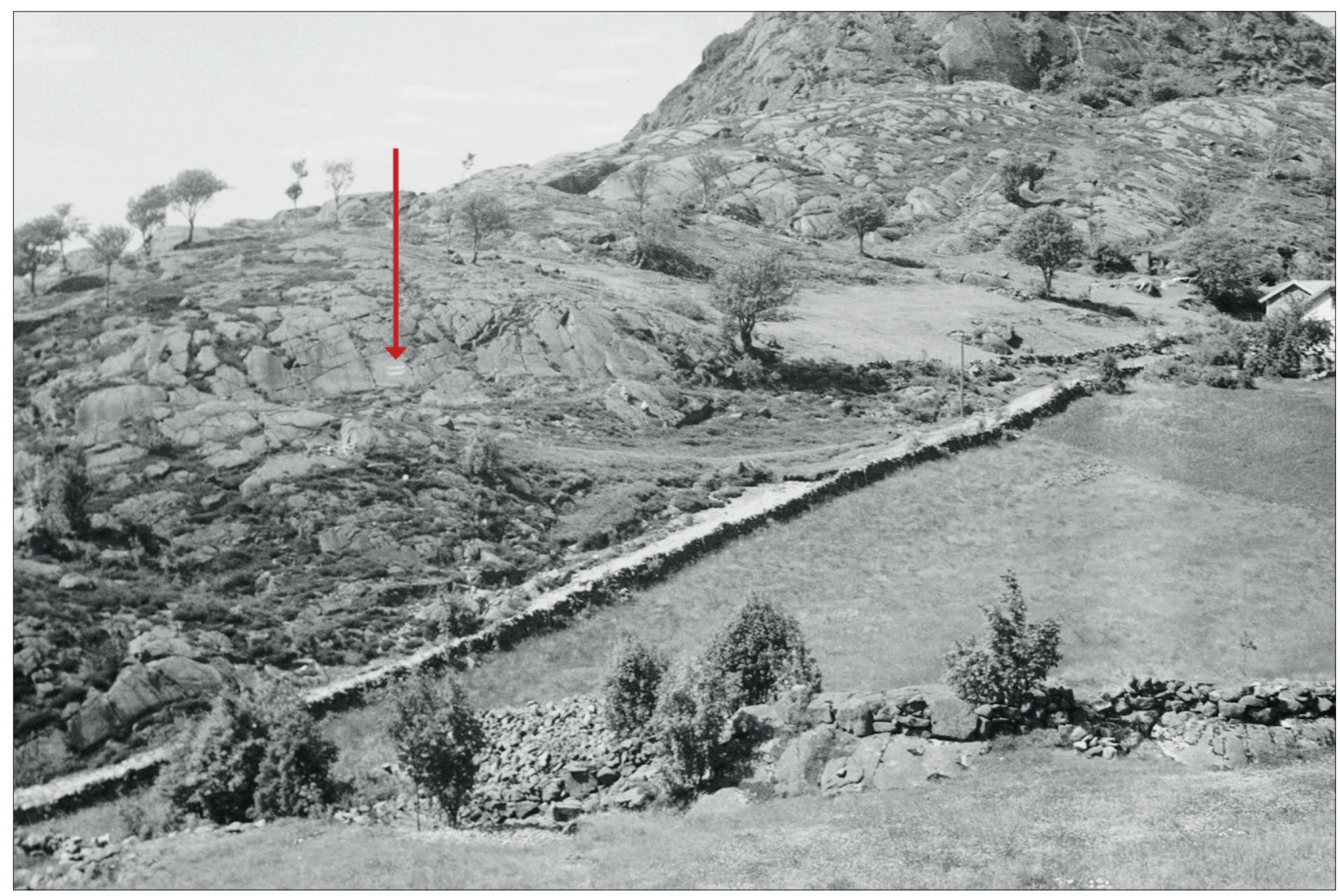

Fig. 42. Landskapet ved Husabølokaliteten på 1930-tallet. Foto: E. og P. Fett (194I).

Fig. 42. The landscape near the rock carvings at Husabø. Photo from the 1930s. Photo: E. and P. Fett (194I). 
trods jeg anvendte meget tid til dette, ikke kunde finne en eneste ristning til». Nyere gransking gjør det fortsatt vanskelig å avgjøre om skipet er et falsum eller ikke, det må derfor fortsatt karakteriseres som en tvilsom originalristning. Begge skipene er av A2-type (Mandt, 1991, s. 47) og dateres til eldre bronsealder og inn i yngre bronsealder (periode I til IV) (Wrigglesworth, 2011, s. 118), skipene kan også sammenlignes med skip nr. 6 i Ling $(2014$, s. 105) som han henfører til periode III.

Både Brøgger og E. Fett og P. Fett karakteriserer skipene som ordinære og av velkjent type der det «eneste av særlig interesse er de to adorantene og gropen på kjølspordene» (E. Fett \& P. Fett, 1941, s. 93). Da gropen er et solsymbol og det i tillegg finnes en mulig lurblåser og et mulig brudepar, er dette en vel negativ karakteristikk.

På tross av at det kun er to sikre skip, er lokaliseringen - på en bratt, godt synlig og innbydende bergvegg med vannsig - en interessant faktor, og som det framgår nedenfor har fjellet tiltrukket seg skriblerier fra lang tid tilbake på tross av at lokaliteten tidligere lå utenfor tettbebyggelsen.

\section{Bergart, geologisk vitring og slitasje}

Bergarten er en gråbrun anortositt. Fjelloverflaten er jevn og solid, men noe ruglete pga. oppstånde plagioklaskrystaller. Spor av rust forekommer. Enkelte mindre enn 1 $\mathrm{cm}$ tykke årer av mer motstandsdyktige mineraler står opp inntil $1 \mathrm{~cm}$ fra fjelloverflaten, og en slik åre skjærer det uferdige skipet vinkelrett på kjølen. Et steiltstående sprekkesystem, orientert sørvest-nordøst er til stede, samt to sprekkesystemer med fall på $45^{\circ}$ som skjærer fjelloverflaten i retningene sørøst-nordvest og nordøstsørvest. Figurene er stort sett lagt utenfor sprekkene, men en svakt utviklet sprekk skjærer gjennom det nederste skipet.

En prøve av fjellet ble tatt ut fra en utsprengt garasjetomt $15 \mathrm{~m}$ nord for figurene. Mikroskopering av et tynnslip fra denne prøven viser at anortositten består av $93 \%$ plagioklas, rundt $6 \%$ muskovitt som ser ut til å ha erstattet spredte pyroksenkrystaller eller andre mineraler, samt spor av frisk pyroksen, biotitt, rutil, opake jern- eller titanoksider, kloritt, og kalsitt i en del tynne sprekker.

Ved undersøkelse i 2009 ble det ikke påvist bommer eller skader på og ved ristningene (Bakke, 2009b).

\section{Endringer over tid og skader påført av mennesker}

Tybring (1904, s. 32) skriver at furene ikke er meget dype og hele. Brøgger karakteriserer figurene på følgende måte: «linjene er nu ikke meget dype, men der er tydeligvis sterkt vandslit i flaten, saa de eroderes stadig ned» (1910b), og E. Fett og P. Fett (1941, s. 92) anfører at teknikken er noe utvisket, men huggesporene ses klart. M.a.o. har linjene alt fra 1904 blitt karakterisert som slitte, noe som kan skyldes vannsig over lokaliteten. Ut fra undersøkelsen i 2009 ser det imidlertid ikke ut som om det foregår kjemisk eller mekanisk vitring, men heller langsomtgående utvisking av linjene. Det er imidlertid ikke umiddelbar fare for forvitring.

Tybring beskriver stedet der ristningene finnes som «aldeles øde og der har aldri stått hus i nærheten, og man maa over en paa sine steder temmelig brat sten- og lyngmark for at naa ned til den» (Fig. 42). «Det er også flittig brugt af nutidens ungdom til udhugning af alskens navne» (Tybring, 1904, s. 32). Også E. Fett og P. Fett påpeker at fjellet er oversådd med monogrammer og nyere skipsfigurer og «ennu verre er det at selve ristningene er opprisset». Ved ØK-registrering i 1967 blir det påpekt at nedre figur synes opprisset (Haaland, 1967a). I dag ses ingen monogrammer, opprissinger eller nyere skipsfigurer, men nederst på feltet er det hogd inn en merkelig dyrefigur antakelig med meisel. Hoggelinjene bærer preg av elde, men er ikke nevnt hos E. Fett og P. Fett (1941, s. 92). I dag er lokaliteten omgitt av hus, hager og vei, landskapet rundt er m.a.o. endret. Dette ser imidlertid ut til å ha hatt en preventiv virkning; ingen nye hogginger er utført de siste tiåra.

Ut fra opplysninger i topografisk arkiv ved Arkeologisk museum kan det se ut til at bare en figur ble malt opp i 1985 (Sør-Reime, 1985b), mens begge figurene ble oppmalt i 1993 av Eide (1993). All maling er i 2018 slitt vekk.

\subsection{Skålgroplokaliteter}

\section{Husabø gnr. 12, bnr. 3, Id 43805}

\section{Historikk, beliggenhet og presentasjon av lokalitet og figurer}

Første melding om skålgroplokaliteten kom i 1972 i forbindelse med planer om utbygging, og hvor Espedal fikk påvist 25 groper (Espedal, 1972). I 1978, i forbindelse med planer om idrettsplass og utvidelse av skolegården, ble det foretatt befaring ved Bang-Andersen og det ble funnet 45-50 groper fordelt på seks grupper på nordsiden av en lav bergknaus om lag 25-30 m SSV for skolebygningen. Bang-Andersen påpeker at størrelsen og dybden varierer sterkt, men de fleste har en diameter på mellom 3 og $5 \mathrm{~cm}$ og en dybde på mellom 1 og $3 \mathrm{~cm}$. Han anfører også at betydelige deler av fjellknausen er dekket av et tynt torvlag, noe som kan skjule flere groper (BangAndersen, 1978).

I forbindelse med et tiltak i 1983 da jorden ble skrapt av, ble det registrert ytterligere 10 til 13 groper (Sør-Reime, 
1984b), og ved oppmaling i 1993 kom det samlete antallet opp i 95 (Eide, 1993). Da berget delvis er dekket av en tilstøtende gressmark, kan gropene fortsette innunder denne, og det kan eventuelt også finnes andre ristninger. Lokaliteten er ikke kalkert.

Grupperingene på lokaliteten er interessante fordi tre, kanskje fire av grupperingene ligger i et tilnærmet innbyrdes overensstemmende system av ti til 13 groper (Eide, 1993).

\section{Bergart, geologisk vitring og slitasje}

Det er ikke foretatt geologiske analyser av lokaliteten eller undersøkt for geologisk vitring og slitasje.

\section{Endringer over tid og skader påført av mennesker}

I 1983 kom det melding til museet om at kommunen v/ skolekontoret hadde skrapt av jord med maskin slik at det var merker etter tenner i fjellet. Det var også asfaltert i enkelte groper. Ved befaring i 1984 ble det konstatert at selve inngrepet neppe hadde skadet lokaliteten. Siden fornminnet ligger inne i skolegården, er det fare for slitasje, men foreløpig er dette ikke påvist. Gropene ble malt opp i 1993 (Eide, 1993).

\section{Årstad gnr. 13, bnr. 148 m.fl., Id 71933}

Lokaliteten ligger på ei stor blokk på en 2 x 3 m nordvestvendt flate, i en hage $15 \mathrm{~m}$ øst for våningshuset og med utsikt mot sørøst, øst og nordøst. Det er hugget inn minst 29 groper over hele flaten, men særlig mange øverst (Fig. 43). Gropene har et tverrmål mellom 6 og $9 \mathrm{~cm}$ og dybde mellom $1 \mathrm{og} 4 \mathrm{~cm}$. Midt på flata er det en $\mathrm{H}$-lignende figur, furene er brede og 1 til 1,5 cm dype (Haaland, 1967b).
Denne er høyst sannsynlig fra nyere tid, likeså kan det være hogd med moderne redskaper i fire av gropene. I 1998 var det presseoppslag der det ble hevdet at gropene var hogd av gutter på 1930-tallet. Dette ble tilbakevist av Arkeologisk museum v/B. Bakke og G. Kjeldsen. (Aftenposten 22/8 1998; Dalane Tidende 28/8 1998). Etter 1998 er det bygd garasje og hus nær steinen.

\section{Drange gnr. 68, bnr. 7, 11, Id 53576}

Lokaliteten ligger østvendt på en nord-sørgående knaus med 45 graders helling i småkupert kulturbeite og med utsikt mot sør og vest, om lag 450 m sørøst for våningshuset på bruket. Det er registrert minst 95 groper, ordnet i fem horisontale grupper med 6 til 20 groper på rekke. 84 av gropene ser ut til å ha vært laget med minebor, og opphav og alder er derfor usikker. Øverst på berget er det fire grupper med to til fire groper som er fra 4 til $6 \mathrm{~cm}$ i diameter og mellom 2 og $3 \mathrm{~cm}$ dype. Disse gropene er trolig ekte (Møllerop, 1958a).

\subsection{Løse heller og blokker med ristninger og skålgroper}

Årstad, gnr. 13, S8473

Gropstein med ei grop. Den er funnet under en nedrevet låve og ble innlevert til museet i 1958. Steinen måler $21 \mathrm{x}$ $30 \mathrm{~cm}$ og har en tykkelse på $10 \mathrm{~cm}$.

\section{Åse, gnr. 19, S4901i}

Gropstein med ei grop. Den ble funnet i 1927 oppå sørmuren i ei tuft datert til 6. århundre. Steinen måler $30 \mathrm{x}$ $32 \mathrm{~cm}$ og har en tykkelse på $14 \mathrm{~cm}$.
Fig. 43. Skålgropstein på Årstad. Foto: Å. Pedersen, AM, UiS. Fig. 43. A huge block with cup marks at Årstad. Photo: $\AA$ Pedersen, AM, UiS.

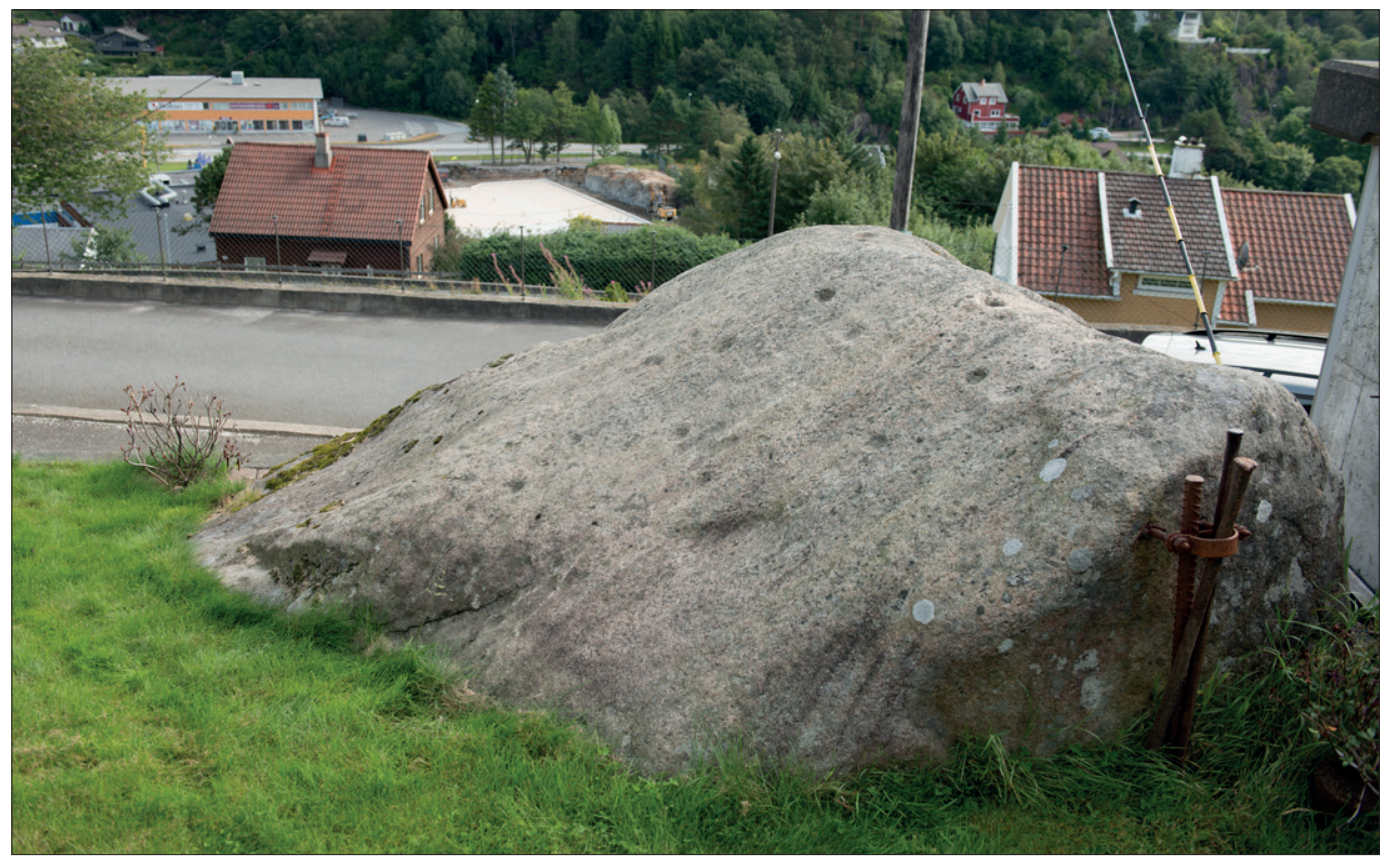




\section{Sokndal kommune}

\section{I Bergkunstlokaliteter}

\section{Haneberg gnr. 46, bnr. 2, Id 24715, Id 5547 \\ Historikk, beliggenhet og presentasjon av lokalitet og figurer}

I 1922 ble Stavanger Museum i brev (Aarstad, 1922) varslet om en helleristning, et skip samt en del skålgroper på gården Haneberg i Sokndal kommune. Aarstad skriver at dersom den ikke er innrapportert og undersøkt tidligere ville det vært bra om dette kunne skje da den muligens kan bli mer eller mindre ødelagt ved byggearbeider inneværende sommer. Petersen befarte stedet i april året etter og fant i tillegg et mindre skip (Petersen, 1923a). I juli samme år ble ristningene nærmere undersøkt og det ble laget en tegning på silkepapir av det største skipet (Petersen, 1923b). Han skriver også at på samme fjell er det ni skålformete fordypninger 5-7 cm i tverrmål, og få meter VSV for skipet er det noen store skålformete fordypninger, opptil $20 \mathrm{~cm}$ i tverrmål samt noen mindre. Lokaliteten ligger i sørkanten av et nord-sørgående berg, om lag 85 m øst for våningshuset på bruket og like inntil Hanebergveien. Nedre del av svaberget heller $30^{\circ}$ mot sørøst, mens det lenger nord er flatt før det igjen heller mot sør. Lokaliteten ligger ikke i tilknytning til sjø, men nær elva Sokna. Skipsristningene er imidlertid ikke vendt mot elva, men fra skålgropene på toppen av svaberget er det utsikt mot den.

E. Fett og P. Fett undersøkte lokaliteten i 1933 og kalkerte begge skipene samt enkelte av skålgropene (1941, s. 95). De delte lokaliteten i fire grupper der gruppene 1 til 3 kun inneholder skålgroper, mens gruppe 4 i tillegg til skålgroper også inneholder de to skipene. Det samlete antallet skålgroper er ikke oppgitt. Ved ØK-registreringen i 1969 (Norland, 1969) ble det talt opp minst 45 skålgroper i tillegg til de to skipene. Ved ny undersøkelse i 1993 (Eide, 1993) ble det funnet nok ei gruppe (gruppe 5), mens det to år etter (Bang-Andersen, 1995) ble registrert ytterligere to grupper, gruppe 6 og 7, der gruppe 6 som er ei flyttblokk med 12 groper, ble flyttet til stedet i 1979 etter å ha ligget i en steingard (id 5547). Til sammen skal det nå være 68 skålgroper på lokaliteten (Hatleskog, 1994); en del er svært vide, over $20 \mathrm{~cm}$ i diameter. Særlig gjelder dette gruppe 1 som ligger på vestsiden av lokaliteten. Denne består nesten utelukkende av vide og grunne groper som også finnes konsentrert i ei gruppe på «Kattaberget» (Bø, id 65874).

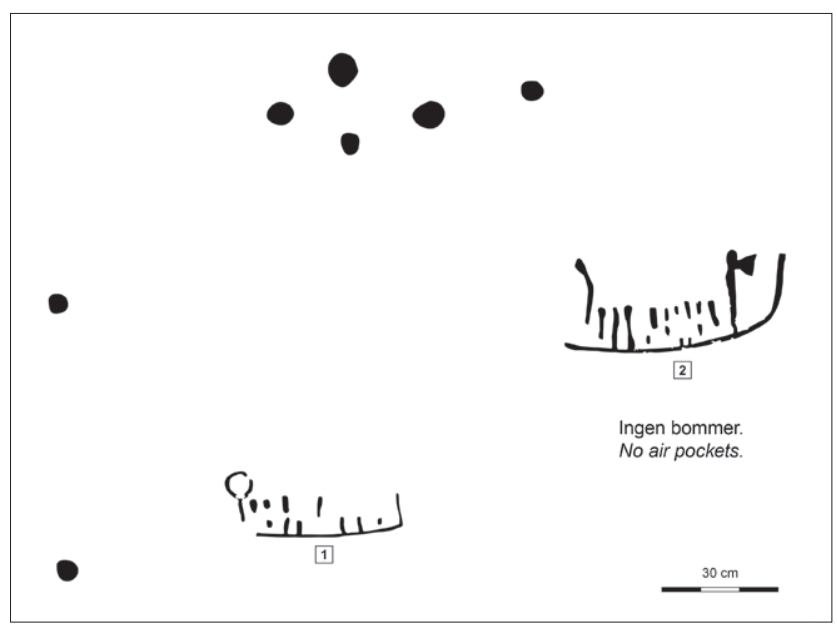

Fig. 44. Kalkering av ristningene på Haneberg, etter Eide (1993). Fig. 44. The traced rock art at Haneberg. After Eide (1993).

Skipsfigur nr. 1 blir av E. Fett og P. Fett (1941, s. 95) kun omtalt ved at linjene er vanskelige å skille fra de naturlige. Da Eide (1993) undersøkte og kalkerte lokaliteten på nytt (Fig. 44) ble båten noe mer interessant. Han skriver at i lavt sidelys framsto figuren klarere, og han fant flere linjerester utover de E. Fett og P. Fett påviste samt en liten og nesten komplett ringfigur (største diameter $7,5 \mathrm{~cm}$ ) som er plassert på en vertikal linjerest etter venstre stavnstokk eller stang. Forbindelsen mellom skroglinjen og evt. stavn eller stang er vitret bort slik at det er vanskelig å si noe sikkert om hva den vertikale linjen under ringen representerer. Eide heller imidlertid mest mot at ringen er plassert på stavnen. Om en tolker ringen som et solsymbol, kan den sammen med den vertikale linjen enten tolkes som en (frittstående) solholder eller at skipet bærer/frakter sola.

Eides dokumentasjon og kalkering av «øksebåten» (nr. 2) i lavt sidelys om kvelden viste at enkelte av linjeavslutningene (som også i denne båten er svake, men likevel mer markante enn nr. 1) har en større bredde enn det E. Fett og P. Fetts kalkering viser. De var fingerbrede og dype nok til å gi en sikker kontur. Kantkonturene generelt var også såpass klare under gode lysforhold at det er liten tvil om at mannskapsstrekene er bredere enn det E. Fett og P. Fett sin kalkering viser, ellers er båten i overensstemmelse med E. Fett og P. Fett sin kalkering (Eide, 1993). Øksa har utsvunget egg og kan minne om en prosesjonssøks, i motsatt del av skipet stikker det opp en lang, bøyd linje som kan tolkes som en lurblåser. 
Begge skipene som er enlinjete med mannskapsstreker er noe atypiske. Skip nr. 2 har en svakt bueformet relingslinje og svak markering av overgangen til stavnen som er svakt utoverbøyd. Selv om den ene stavnen mangler, kan nr. 2 nærmest karakteriseres som et B3-, eventuelt et B4-skip (Mandt, 1991, s. 47) og dateres dermed innenfor bronsealderens periode III til VI/førromersk jernalder (Wrigglesworth, 2011, s. 118). Skip nr. 1 er enda mer problematisk, den har rette stavner, men er likevel ulik B1-skipene. Nærmeste parallell er skip nr. 15 hos Ling (2014, s. 105), en skipstype som er karakteristisk for førromersk jernalder. Det kan se ut som om begge skipene seiler mot høyre.

Lokaliteten ligger innenfor et svært rikt fornminneområde med mange løsfunn og faste kulturminner slik som «piggsteinen» som ligger ved elva og der det i nærheten skal ha stått reiste stein i en sirkel, ca. $15 \mathrm{~m}$ i tverrmål, og som i et tinglysingsdokument fra 1746 er omtalt som «den runde ager» eller «dugen» (Skjølsvold, 1961), gravhauger samt «offeralteret» (se bla. Petersen, 1952) som ligger om lag $350 \mathrm{~m} \varnothing \mathrm{N} \varnothing$ for ristningene. Lokaliteten er spesiell i Rogaland pga. de store og vide skålgropene som Skjølsvold (udatert) karakteriserte som de største han noensinne har sett, skipsfigur med solsymbol og ikke minst «øksebåten» som E. Fett og P. Fett (1941, s. 95) karakteriserer som «enestående i Rogaland».

\section{Bergart, geologisk vitring og slitasje}

Skipene og skålgropene nærmest skipene ble undersøkt. Bergarten tilsvarer gabbrobergarten som finnes ved bergkunstfeltet på Bø (id 65874). Fjellets overflate er solid uten sprekker og avskallinger, men noe ruglete pga. oppstående mineralkorn. Relieffet er like stort i og utenfor figurene, unntatt i deler av sørøstligste skip der linjene kan ha blitt polert i nyere tid.

En prøve av fjellet ble tatt ut i skjæringen på sørsiden av Hanebergveien, $10 \mathrm{~m}$ sør for skipsfigurene. Mikroskopering av et tynnslip laget fra prøven viser at gabbroen består av nesten $70 \%$ plagioklas, $20 \%$ pyroksen, $6 \%$ opake jern-titanoksider, $4 \%$ nefelin og spor av biotitt, sericitt og rustutfellinger mellom plagioklaskrystaller. Enkelte oppløsningsporer dannet ved pyroksenoppløsning er antagelig til stede.

Ved fjerning av lav i 2006 ble det observert avskallinger; der laven var relativt tykk satt det 1-2 mm fliser av fjellet.

\section{Endringer over tid og skader påført av mennesker}

I Petersens innberetning (1923b) står at skipet (dvs. nr. 2) her var svært utydelig, og «jeg var ikke så heldig at faa se det under den bedste belysning. Jeg tog dog en silkepapirtegning av skibet slik som jeg formoder den har været ...». E. Fett og P. Fett (1941, s. 95) skriver at steinarten er temmelig hård, men karakteriserer skip nr. 1 som så svak at linjene er vanskelige å skille fra naturlige, mens skip nr. 2 er sikker, kjølen og stavnene er kraftige, mens mannskapsstrekene er svake. Som nevnt ovenfor påpeker også Eide (1993) at skipene er svært vitret, særlig nr. 1. I 2009 er bildet uforandret (Bakke, 2009b), det ble imidlertid ikke registrert «bommer». Ut fra tidligere beskrivelser er det m.a.o. vanskelig å påvise endringer over tid.

I 1939 fikk J. Petersen melding om at noen gutter hadde malt på bergkunsten på Haneberg (Petersen, 1939). På tross av at lokaliteten ligger like inntil vegen, har den aldri seinere blitt påført menneskeskapte skader.

Eide skriver i 1993 (1993) at alle tidligere fargemarkeringer er borte. Det finnes imidlertid ikke arkivopplysninger om når det evt. skulle ha blitt foretatt oppmaling. Ut fra eldre fotografier ser en imidlertid at ristningene er markert med hvitt, antakelig kritt. Eide påførte i 1993 skipsfigurene samt gropene i gruppe 1, 3 og delvis i gruppe 4 kokt linolje før oppmaling. Det er ikke blitt foretatt oppmaling seinere, og i 2018 er malingen så å si slitt vekk.

\section{Bø gnr. 56, bnr. 28, Id 65874}

Historikk, beliggenhet og presentasjon av lokalitet og figurer

Stavanger Museum fikk melding av Aarstad i 1923 om funn av en båtfigur. Samme år befarte Petersen lokaliteten (1923b), og etter å ha fjernet gresstorva ble det funnet ytterligere fire skip samt tre skålgroper, i tillegg ble det påvist to gropfelt like ved. Petersen fotograferte, beskrev og tegnet av skipsfigurene på silkepapir (i arkivet ved AM, UiS, er figurene overført på millimeterpapir). E. Fett og P. Fett undersøkte lokaliteten i 1933 (1941, s. 93-94). I tillegg til Petersens ristninger i gruppe 1 påviste de en mulig fotsåle samt en samling med fire korte streker. En sikker skålgrop er av en eller annen grunn ikke tatt med på kalkeringen. Lokaliteten ble kalkert på nytt av Eide i 1993 (Fig. 45).

Lokaliteten ligger på toppen av en fjellknaus på nordsida av Sokna. I sør går det bratt ned mot elva. I dag er lokaliteten delvis omgitt av parkeringsplass for buss, og knausen med figurene ligger om lag $10 \mathrm{~m} \mathrm{SS} \varnothing$ for bygninger tilhørende rutebilstasjonen. Mellom elva og knausen er det anlagt en tursti.

Lokaliteten er om lag $10 \times 5 \mathrm{~m}$ i utstrekning og orientert øst-vest. Gruppe 1 som inneholder skipsfigurene, skålgropene og den mulige fotsålen, ligger innenfor et område på 1,3 x 1,7 m lengst vest på lokaliteten, ca. $7 \mathrm{~m}$ øst for disse finnes ti groper innenfor et om lag $2 \times 1 \mathrm{~m}$ stort område (gruppe 2). Dessverre er det boret i tre av 


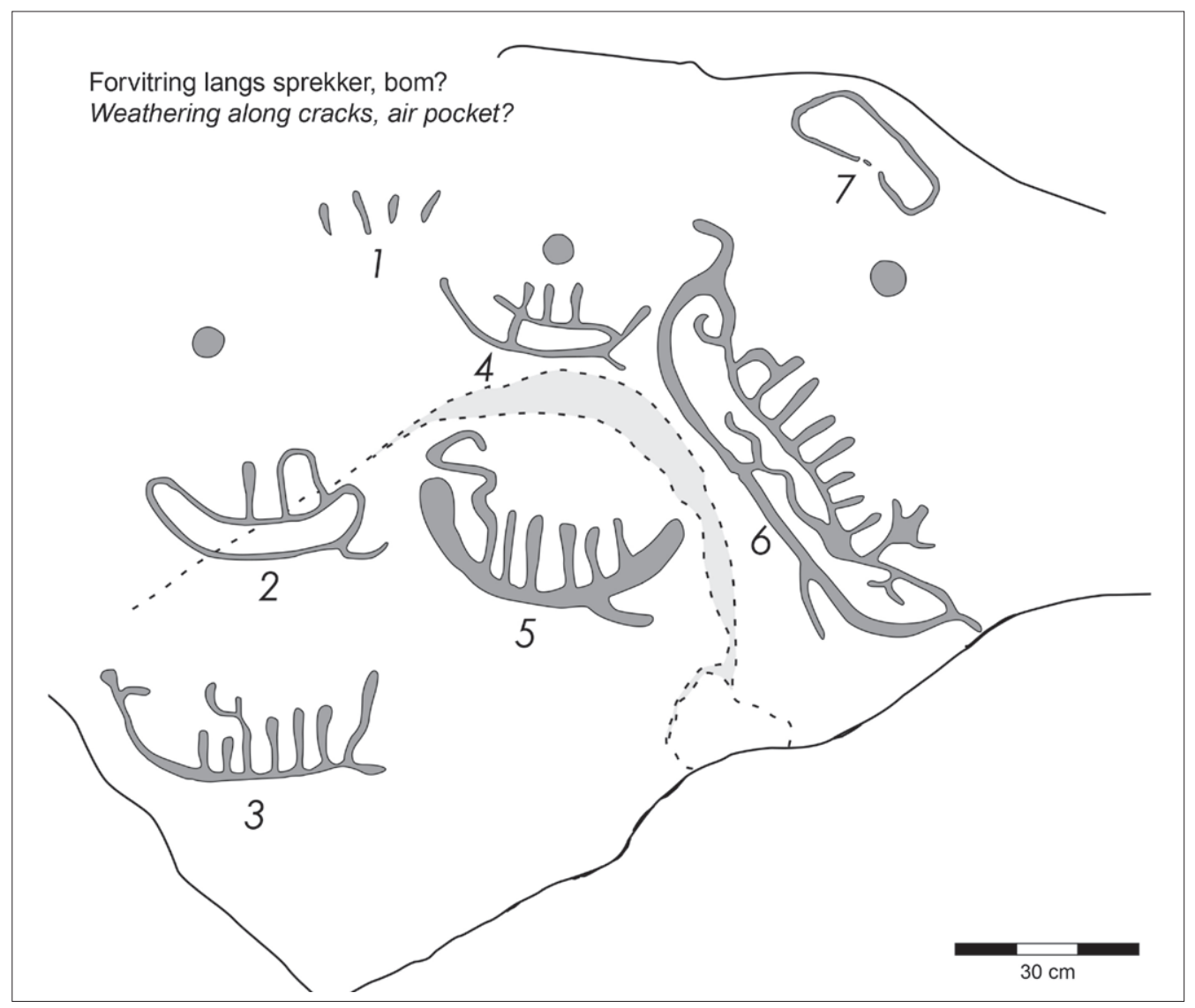

Fig. 45. Kalkering av ristningene på $\mathrm{B} \varnothing$, etter Eide (1993).

Fig. 45. The traced rock art at Bø. After Eide (1993). dem (se Fig. 46). De er svært grunne og vide, opptil 18 $\mathrm{cm}$ i diameter og 5-6 m nordøst for denne gruppa ligger ytterligere fire groper (gruppe 3).

Skipsfigurene har som E. Fett og P. Fett (1941, s. 94) riktig påpeker, et helt annet preg enn de øvrige rogalandsristningene. Linjene er mykere og mindre stramme. De er videre plassert på en noe konkav flate som kan minne om et «alter», og en sprekk skiller figurene nr. 2, nr. 3 og nr. 5 fra de øvrige. Samtlige skip ser ut til å seile mot venstre.

Skipsfigurene er spesielle, hos E. Fett og P. Fett (1941. pl. 41) er det på kalkeringene avtegnet dyrehodelignende avslutning i stavnen på nr. 4. Denne mangler på Eides

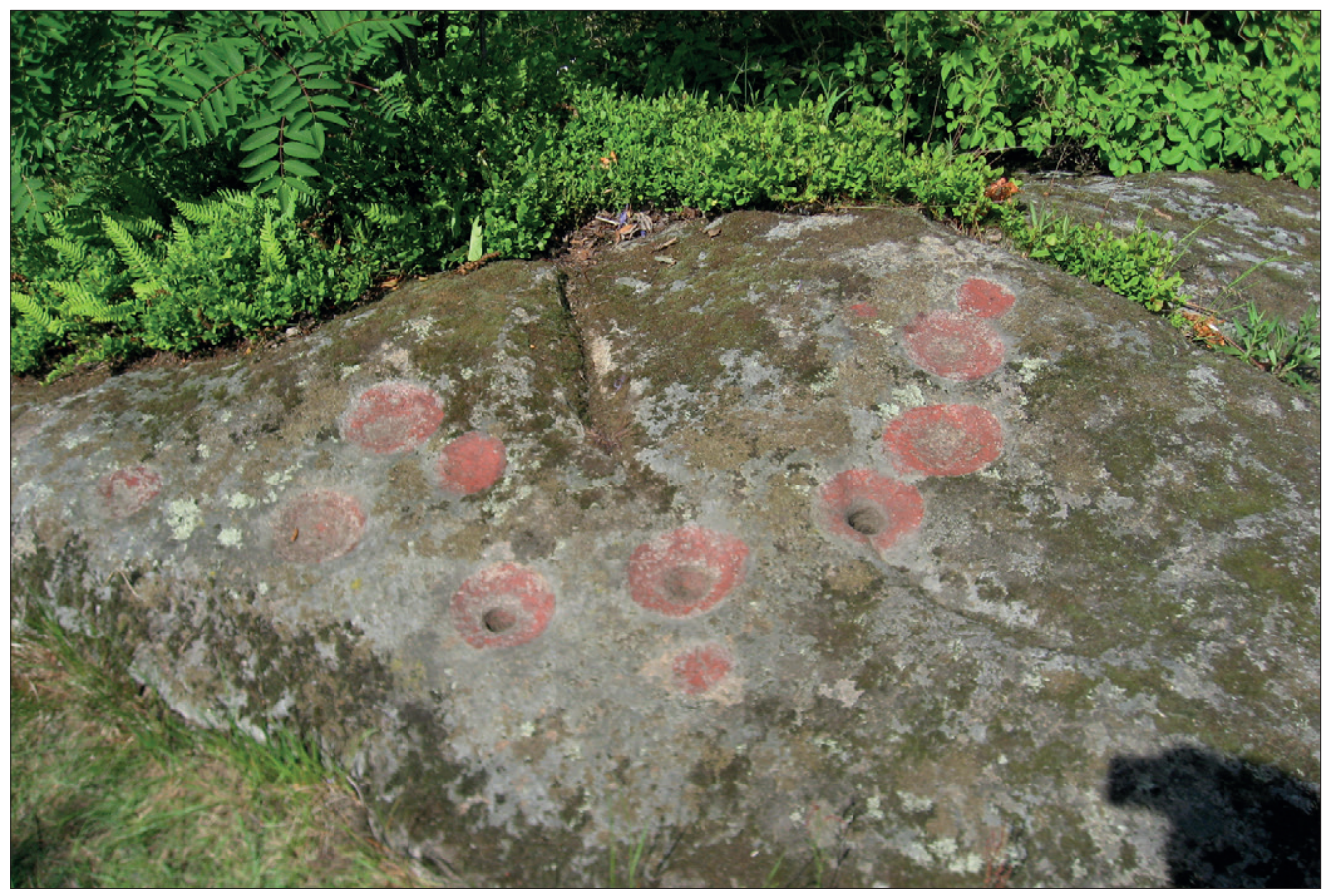

Fig. 46. Dype skålgroper på Bø. Foto: L. PrøschDanielsen, AM, UiS. Fig. 46. Site with deep cup marks at Bø. Photo: $L$. Prøsch-Danielsen, AM, UiS. 


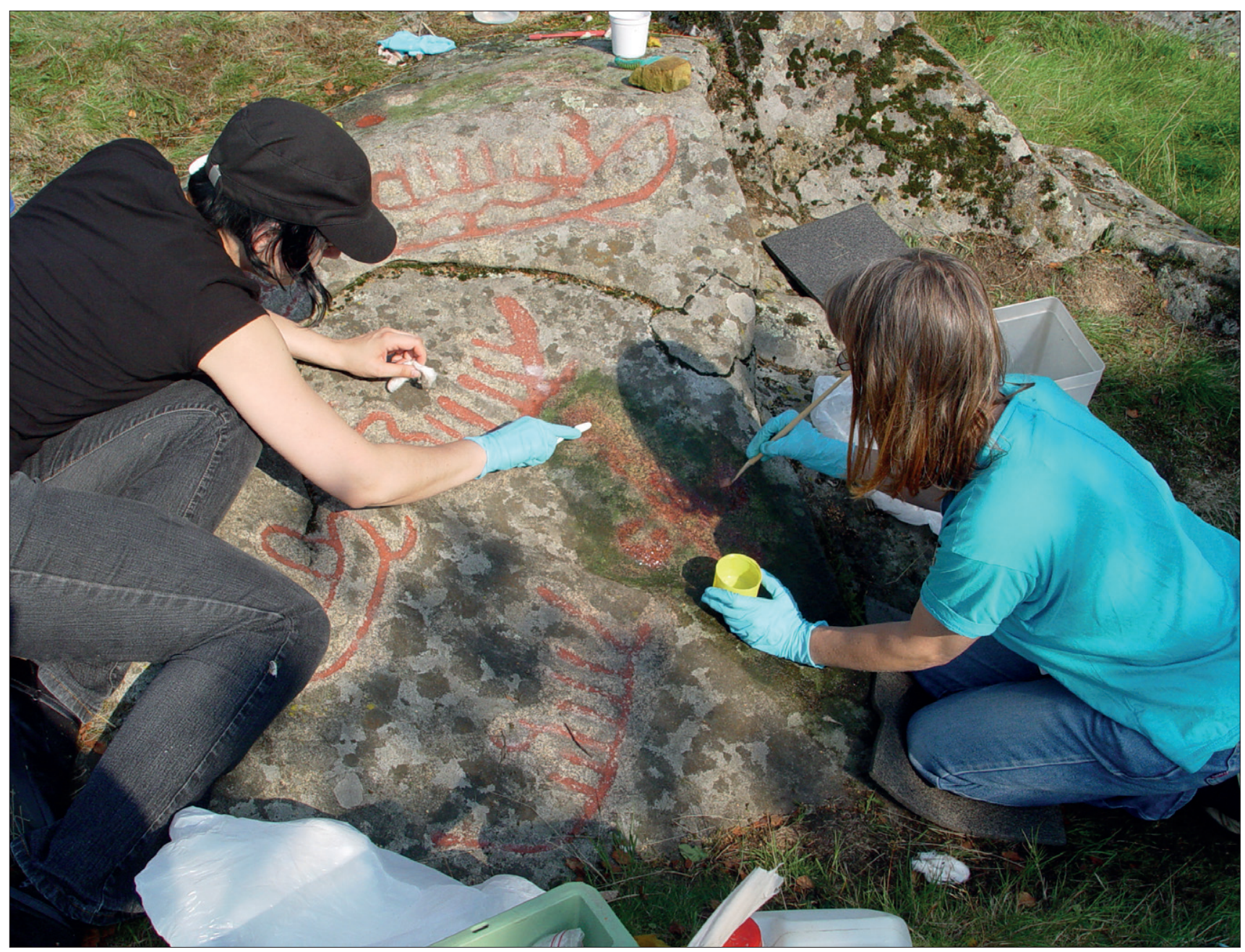

Fig. 47. Hærverk på bergkunstfeltet på Bø. Fjerning av malingen i 2006. Foto: K. B. Davies, AM, UiS.

Fig. 47. An act of vandalism (painting) was committed at the rock carvings at Bø. The painting was removed in 2006. Photo: K. B. Davies, AM, Uis.

kalkeringer. Ellers er kalkeringene nokså like, bortsett fra at E. Fett og P. Fett har avtegnet furene noe bredere. På nr. 5 og nr. 6 er det slangelignende figurer, eller skal den på nr. 5 heller tolkes som en lurblåser? Muligens ses det en menneskefigur med utstrakte armer på nr. 6. E. Fett og P. Fett tolker et «brudepar» på nr. 2 og kanskje nr. 6, mens i nr. 3 er det en adorant eller lurblåser. I det hele er figurene interessante med fine detaljer. Tre av skipene (nr. 2, nr. 4 og nr. 6) er konturhogde av den seine typen, mens nr. 3 nærmest er et B3-/B4-skip (Mandt, 1991, s. 47), dvs. lokaliteten kan dateres til de yngre deler av yngre bronsealder/ førromersk jernalder (Wrigglesworth, 2011, s. 118).

Gropene i gruppe 2 er også spesielle ved at de er vide og grunne. Det kan virke som om de er spesielle for dette området (jf. gropene på Haneberg, id 24715).

Sør-Reime (1985b) karakteriserer lokaliteten som svært interessant, ikke minst framheves forholdet mellom formasjoner i berget og figurenes plassering, med visse paralleller til Flubergets «alter» (id 24610, Stavanger), og han påpeker også skipenes unike utforming.

\section{Bergart, geologisk vitring og slitasje}

Bergarten er en gabbro. Fjelloverflaten virker solid, men er ru pga. oppstående mineralkorn. En markert, nokså flattliggende sprekk, forekommer mellom noen av skipene, men det ser ikke ut til å være noen stor fare for avskalling av deler av figurer. Bergarten er den samme i skålgropfeltet (gruppe 2). Også her er bergoverflaten i god stand, om enn noe ru pga. oppstående mineralkorn. Sprekker mangler, men tre av skålgropene er skadet ved boring av et hull midt i hver av gropene. Gruppe 3 ble ikke undersøkt.

Ved Bakkes undersøkelse i 2009 (se Fig. 45) ble det påvist bommer og forvitring langs den naturlige sprekken. Det ble også påpekt at overflata er kornete, men stabil.

\section{Endringer over tid og skader påført av mennesker}

E. Fett og P. Fett (1941, s. 94) karakteriserer bergarten som hard og kornete der linjene er bredere enn vanlig og med jevnt buet tverrsnitt og uskarp overgang til flaten. «Alle linjene er helt utvilsomme, hugning ses klart.» 
Linjefragmentene i figur nr. 1 er de eneste som ikke er helt tydelige, men de påpeker at også disse nok er sikre. Ut fra tidligere beskrivelser er det vanskelig å påvise endringer over tid. Berget var også i 1933 kornete. E. og P. Fett kommenterte imidlertid ikke sprekken, det er derfor vanskelig å vite om det også den gang fantes bommer og forvitring langs kanten.

E. Fett og P. Fett (1941, s. 94) påpeker at midtpartiet på knausen er sprengt vekk, og at det etter dette bla. står igjen en $15 \mathrm{~cm}$ høy vegg som tangerer ei av gropene i gruppe 2. Ved ØK-registreringen i 1969 (Espedal, 1969) blir det påpekt at det er boret med minebor i tre av gropene $\mathrm{i}$ samme gruppe. E. Fett og P. Fett (1941, s. 94) påpeker at i gruppe 3 er den naturlige sprekken mellom gropene utvidet av mineskudd. Petersen (1923b) nevner ikke at fjellet var sprengt og E. Fett og P. Fett (1941, s. 94) nevner ikke boring i gropene. Lokaliteten kan derfor ha blitt påført menneskeskapte skader, først i perioden 1923 til 1933 og deretter i perioden 1933 til 1969. Seinere har plan for opparbeiding av tursti vært behandlet (1977/1988) og turstien er anlagt mellom knausen med bergkunst og elva.

Neste gang lokaliteten ble påført skade var i 2006 da det under den årlige bergkunstbefaringen ble oppdaget to rødmalte figurer på flaten i gruppe 1 , nær selve ristningene; en korslignende figur og en noe mer ubestemt. Etter ulike forsøk fikk en fjernet storparten av malingen (Fig. 47), korsfiguren var fortsatt noe synlig etter behandlingen (Borgarp, 2006), men alt i 2009 var sporene etter hærverket så å si slitt vekk.

Lokaliteten ble krittet opp ved ovennevnte dokumentasjon i 1923 og 1933. Første gang det er levert inn rapport om oppmaling er i 1991 da det ble malt med rødbrun Drygolin med ren terpentin (Hernæs, 1992e), men i 1985 ble det rapportert at malingen var dårlig, m.a.o. må det ha blitt foretatt oppmaling tidligere, antakelig i 1982. Da ble det foretatt en grundig opprydding på stedet, og i innberetningen står det at figurene vil bli malt og lokaliteten skiltet (Bang-Andersen, 1982b). Lokaliteten ble på nytt malt opp i 1993 og Eide (1993) bemerker at det var lite lav og mose på ristningene, men likevel nok til at noe lav før eller seinere vil komme i kontakt med noen av ristningene. Figurene og gropene ble derfor penslet med et tynt strøk linolje tilsatt soppdreper før de ble malt opp.

\subsection{Landskap i endring}

Det er laget en strandlinjekurve for Eigerøya utenfor Eigersund (Fig. 48) (Simonsen, 2005; Prøsch-Danielsen, 2006). Ifølge denne strandlinjekurven, som også kan være representativ for Dalane-regionen, sto havnivået omkring $4 \mathrm{~m}$ høyere enn i dag ved inngangen til eldre bronsealder (bronsealder periode I) omkring 1700 f.Kr. Ved inngangen til yngre bronsealder (bronsealder periode IV) omkring 1100 f.Kr., sto havnivået bare $2 \mathrm{~m}$ høyere enn i dag.

I 2015 kom en ny strandlinjekurve for Lista-området (Romundset et al., 2015). Her trekkes isobasen for Tapes maksimum på $5 \mathrm{~m}$ over dagens havnivå omkring 5400 f.Kr. ved sørenden av Refsvatnet i Sokndal. Det betyr ikke at havnivå nådde inn til dette vannet, men at det dog gikk inn så langt 5 meters-koten er trukket på Fig. 49 i sein-mesolitikum. Fra ca 5055-5010 f.Kr. og fram til inngangen til sein-neolitikum 1955-1920 f.Kr. sank havnivå med 0,4 mm pr. år, dvs. til 3,8 m. Videre sank det 2,6 mm pr. år de neste 500 år. Det betyr at havnivået sto $3,3 \mathrm{~m}$ over dagens havnivå ved inngangen til eldre bronsealder om denne kurven er representativ for Sokndalsområdet. Gjelder Eigersundkurven, kan Bø-lokaliteten ha vært nådd ved springflo i eldre bronsealder. Havvannet kan ha

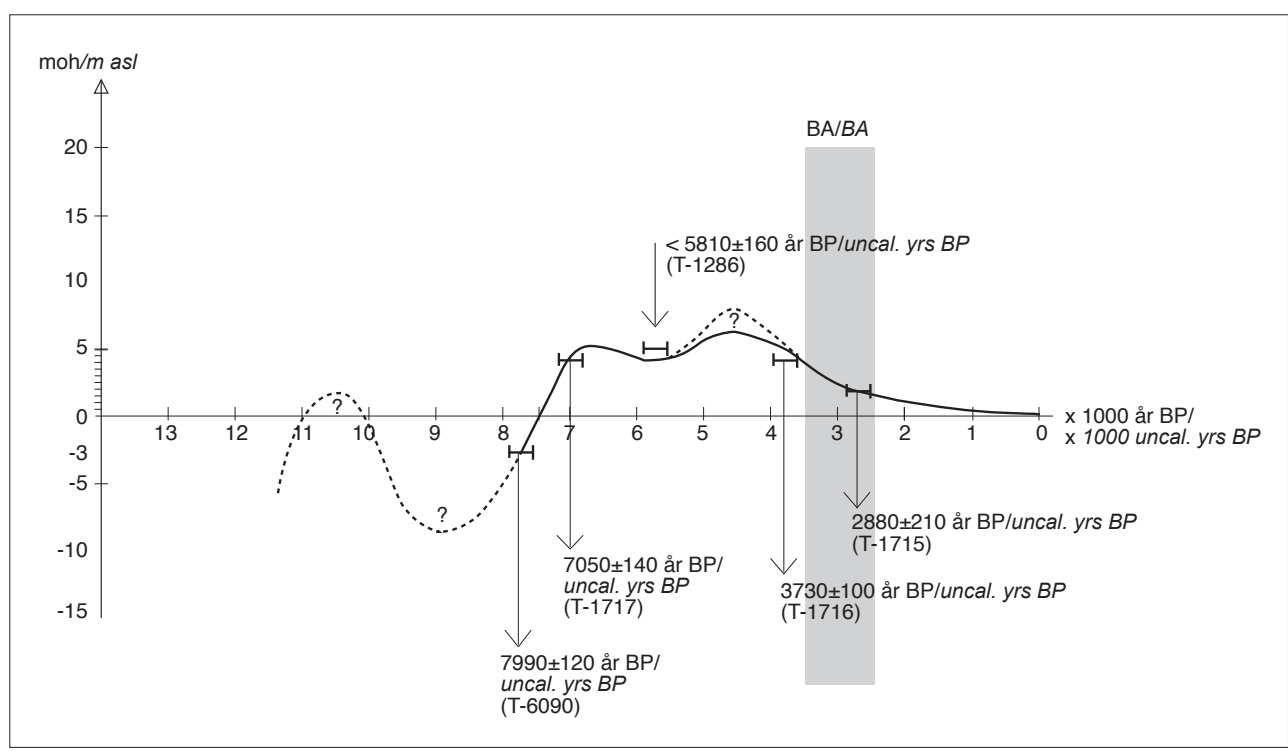

Fig. 48. Beregnet strandlinjekurve for ytre deler av Eigerøya, Eigersund (etter Simonsen, 2005; Prøsch-Danielsen, 2006). Bronsealder er lagt inn ved en gråtone.

Fig. 48. The sea-level fluctuation curve for the Eigersund (Eigerøya) region (after Simonsen, 2005; PrøschDanielsen, 2006). The sea-level in the Bronze Age is marked grey. 


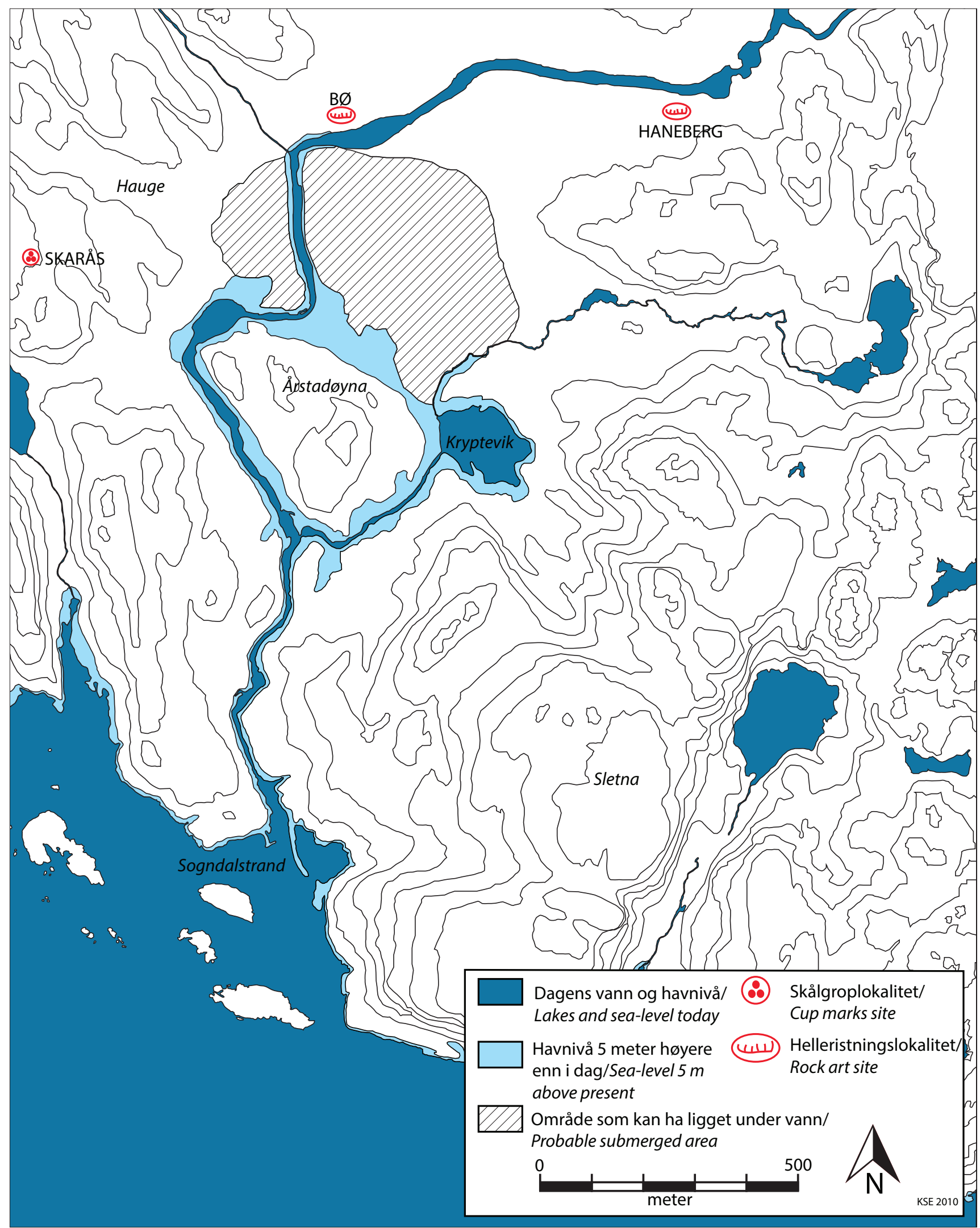

Fig. 49. Lokalisering av bergkunstfeltene Bø og Haneberg i Sokndal. Havnivået ved inngangen til eldre bronsealder periode I (I700 f.Kr.) sto antagelig omlag 3,3 m høyere enn i dag. Feltet ved Bø kan ha ligget i havnivå ved springflo. Elva Sokna knytter Haneberg og Bø sammen. Kart: L. Prøsch-Danielsen \& K. Eilertsen, AM, UiS.

Fig. 49. The localization of the rock carvings at Bø and Haneberg in Sokndal. The sea-level in EBA (I700 BC) was probably $3.3 \mathrm{~m}$ higher than today. The rock carvings at Bø might have been connected to the sea during spring-tide. The rock carvings at Haneberg and Bø are connected through the river Sokna. Drawing: L. Prøsch-Danielsen \& K. Eilertsen, AM, UiS. 
trengt inn gjennom det trange inn-/utløpet ved Strondo og nådd helt opp til det nedre ristningsfeltet ved Bø ved inngangen til eldre bronsealder ved springflo (Fig. 49). Havet har også trengt inn til Kryptevik via Kielland der Kiellandsåna renner i dag og videre gjennom Brusund til Tuen i sein-mesolitikum og neolitikum. Øykollen og Årstadøyna kan bære sine navn med rette; de må da ha vært øyer i et gruntvanns-område. Dette gruntvannsområdet kan også ha gått over de lave elveavsetningene som finnes på begge sider av elva ved Årstad og Tuen, men som seinere eller samtidig har blitt fylt opp av elveavsetninger. Elveavsetningene fikk på et tidspunkt en slik mektighet at Sokna tok et løp slik det har i dag. Her var god tilgang på fiske i elva og rik tilgang på både fugl, fisk og sjøpattedyr i et vidt og stort gruntvannsområde.

I Sokndal ligger de to bergkunstlokalitetene Hanaberg (øverst i dalføret) og $\mathrm{B} \varnothing$ (nederst) orientert mot elva Sokna. Det er svakt fall i elva mellom de to lokalitetene. Bergkunsten er hogd på noen bergknauser som stikker opp i et ellers flatt område der dalføret vider seg ut. Lokalitetene ligger i dag 3-3,5 km fra utløpet av Sokna der elva brått faller $5 \mathrm{~m}$ og renner ut i havet ved Strondo. I perioder med stor vannføring kan de siste 200 meterne fortone seg dramatisk idet elva renner ut i havet gjennom en trang passasje, men i bronsealder har ikke dette fallet vært like stort. Første inntrykk er at det er tilgangen til vann og elva som har vært avgjørende for plasseringen av lokalitetene.

\subsection{Skålgroplokaliteter}

\section{Rossland, gnr. 6, bnr. 5, Id 54345}

Historikk, beliggenhet og presentasjon av lokalitet og figurer

Lokaliteten som består av åtte skålgroper ble funnet i forbindelse med ØK-registrering i 1969 (Gausland, 1969a). Skålgropene ligger på en svakt hellende nordvest-sørøstgående bergknaus. Den nordligste gropa ligger 15,7 m rett sørøst for det sørvestre hjørnet av det gamle våningshuset (Fig. 50). Lokaliteten strekker seg 13 m nordvest-sørøst, gropene er fra 5 til $10 \mathrm{~cm}$ i diameter, mens dybden er mel$\operatorname{lom} 2 \operatorname{og} 6 \mathrm{~cm}$.

Lokaliteten ligger i et område med mange og spesielle kulturminner, bla. Rosslandsguden og kulturminneområdet «hustuptå» (id 24725) med bautastein, hustufter, gravminner etc. samt skålgropsteinen «Gyrå» (se nedenfor, id 72384) (Dahl 2003).

\section{Bergart og geologisk vitring og slitasje}

Bergarten er gabbro. Overflaten i og rundt skålgropene er ujevn, og under torven som omgir skålgropene ses

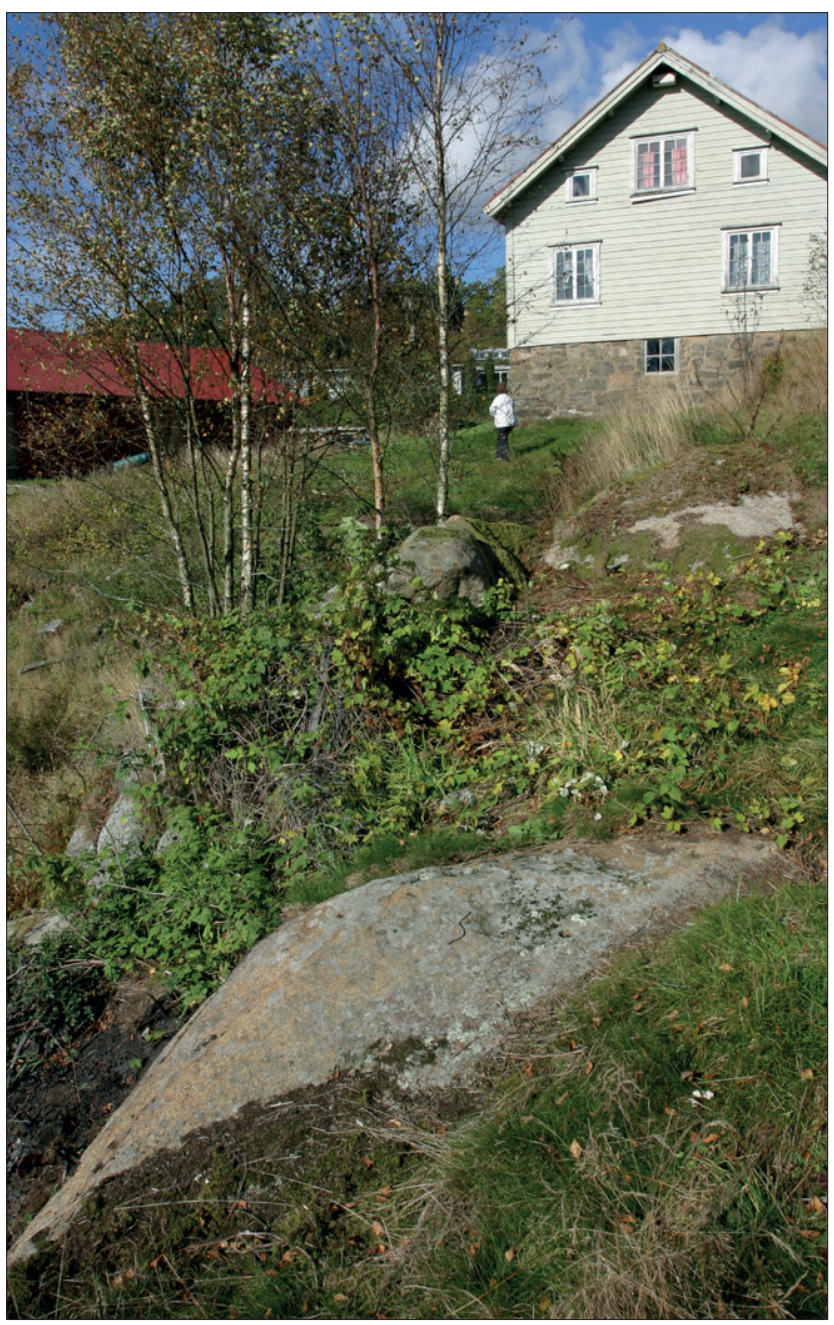

Fig. 50. Felt med skålgroper på Rossland i 2004. Foto: Å. Pedersen, AM, UiS.

Fig. 50. Site with cup marks at Rossland in 2004. Photo: $\AA$. Pedersen, AM, UiS.

rusting og tegn til oppsmuldring av berget. Skålgropa som ligger på toppen av en løs gabbroblokk, ser ut til å være i god stand.

\section{Endringer over tid og skader påført av mennesker}

I rapporten fra 1969 er det ikke opplyst i hvilken grad fjellet er forvitret. Det er derfor vanskelig å avgjøre om det har skjedd endringer de siste 40 årene. Gropene er ikke malt opp.

\section{Rossland, gnr. 6, bnr. 5 - «Gyrå», Id 72384}

Historikk, beliggenhet og presentasjon av lokalitet og figurer

Lokaliteten, en reist stein med skålgrop i toppen, ble registrert for Økonomisk kartverk i 1969 (Gausland, 1969b), men var kjent fra tidligere (se Møllerop, 1958b). Da det er en bautastein, er det nærliggende å datere den til eldre jernalder.

Steinen står på en NNØ-SSV-gående flat rygg i kulturbeite om lag $210 \mathrm{~m}$ sør for våningshuset på bruket. 
Bunnflata er rektangulær, steinen smalner mot toppen, og øverst er den formet som et «hode». På toppen finnes en skålgrop, tydelig og noe oval i formen, største diameter er $5 \mathrm{~cm}$ og dybden er $1,5 \mathrm{~cm}$. Steinens bredde er $0,75 \mathrm{~m}$ og høyden $1,5 \mathrm{~m}$.

Steinen som kalles «Gyrå» har en spesiell form. I følge Møllerop (1958b) minner den i profil sterkt om kvinneskikkelsen på gullgubbene. Det er imidlertid vanskelig å avgjøre om det er spor etter hugging.

Lokaliteten ligger i et område med mange og spesielle kulturminner, bla. Rosslandsguden og kulturminneområdet «Hustuptå» (id 24725) med bautastein, hustufter, gravminner samt de ovennevnte skålgropene (Dahl, 2003).

\section{Bergart, geologisk vitring og slitasje}

Det er ikke foretatt bergartsanalyse av steinen. Steinen og skålgropa ble i 1969 karakterisert som en del forvitret.

\section{Endringer over tid og skader påført av mennesker}

Tilstanden virker å være uendret fra 1969. Det er ikke observert skader påført av mennesker. Gropa er ikke malt opp.

\section{Hauge, gnr. 55, bnr. 16 - «Skolehaugen», Id 65873} Historikk, beliggenhet og presentasjon av lokalitet og figurer

Lokaliteten ble registrert for Økonomisk kartverk i 1969 (Gausland, 1969c). Lokaliteten ligger på en fjellknatt i det sørvestre hjørnet av skolegården. Lokaliteten består av to skålgroper, er klart markert og godt synlig om lag $36 \mathrm{~cm}$ fra hverandre og er orientert ØS $\varnothing-V N V$. Gropene er 5-6 $\mathrm{cm}$ i diameter og 1,5-1,7 $\mathrm{cm}$ dype.

Lokaliteten ligger innenfor et område med flere lokaliteter med skålgroper (store og vide) og figurer, men omgivelsene er sterkt forstyrret og framstår som lite spektakulære (Bang-Andersen, 1995).

\section{Regeland øvre, gnr. 70, bnr. 1, Id 65880}

Historikk, beliggenhet og presentasjon av lokalitet og figurer

Skålgroplokaliteten ble registrert for Økonomisk kartverk i 1970 (Espedal, 1970). Den ligger 25 m SS $\varnothing$ for våningshuset på gården på toppen av en liten bergnabbe. Tre klart markerte skålgroper ligger på rett linje. Gropenes diameter er mellom 7 og $10 \mathrm{~cm}$ og dybden mellom 2 og 4,5 cm.

\section{Endringer over tid og skader påført av mennesker}

Etter registreringen i 1970 ble lokaliteten først befart i 2018. Det ble ikke observert endringer eller skader påført av mennesker. Lokaliteten er ikke malt opp.
Skarås, gnr. 77, bnr. 8 - «Prestebakken», Id 72386

Historikk, beliggenhet og presentasjon av lokalitet og figurer

På et flatt fjell i hellende terreng mot øst, om lag $50 \mathrm{~m}$ vest for våningshuset på bruket og $13 \mathrm{~m}$ øst for skiftet mellom gnr. 77/8 og 77/9, ca. $5 \mathrm{~cm}$ under veggrusen i søndre del av vegkant, skal det ligge en mulig båtfigur. Opplysningene stammer fra registrering for Økonomisk kartverk som ble utført i 1969 (Gausland, 1969d).

Skarås, gnr. 77, bnr. 9, 15 - «Kjerkebakka», Id 72387

Historikk, beliggenhet og presentasjon av lokalitet og

figurer

Lokaliteten som første gang ble undersøkt av E. Fett i 1933 (1941, s. 93), ligger på et svakt skrånende sørvendt flatt svaberg, like ved en grensestein, om lag 100 m øst for husene på gården, på toppen av åsen sør for Hauge i Dalane. Tidligere var det vid utsikt mot sjøen og bygda. I dag ligger feltet inne i skog med sitkagran og furu. Det er registrert fire 5-7 cm vide groper innenfor $0,2 \times 0,3 \mathrm{~m}$ der to og to muligens er forbundet med linjer.

Lokaliseringen samt de mulige linjene som muligens forbinder to og to av gropene, er et interessant trekk.

Bergart, geologisk vitring og slitasje

Bergarten er gabbro. Fjelloverflaten virker solid, er uten sprekker eller avskallinger, men noe ru og ujevn i og utenfor gropene. At fjellet er uten sprekker, hindrer at røtter kan trenge inn på eller nær gropene.

\section{Endringer over tid og skader påført av mennesker}

Fra lokaliteten ble registrert i 1933, og fram til siste tilstandsinspeksjon i 2017 er det ikke observert endringer eller skader påført av mennesker. Lokaliteten er ikke malt opp.

\section{Bjelland, gnr. 107, bnr. 314, Id 64772}

Historikk, beliggenhet og presentasjon av lokalitet og figurer

Lokaliteten ble registrert av Rogaland fylkeskommune i 1998 (Bødal, 1998) og ligger på enden av en fjellhylle mellom Eiavatnet og Eptavatnet. Det er påvist omlag 150 groper innenfor $3 \times 10 \mathrm{~m}$. Gropenes diameter er mellom 1 og $4 \mathrm{~cm}$.

Lokaliteten er ikke befart av tilsatte ved Arkeologisk museum, UiS. 


\section{Historikk, tilstand og miljø}

\section{I Når ble ristningene funnet og registrert?}

De 15 bergkunstlokalitetene i undersøkelsesområdet ble registrert mellom 1902 og 1992; faktisk er de to første og den siste som ble påvist alle fra Ølberg i Sola kommune (Ølbør I til III). Før 1920 er det registrert fire, mellom 1920 og 1940 fem, i perioden 1941 til 1960 tre, i perioden 1961 til 1980 to, mens etter 1981 er det kun påvist en ny lokalitet. Som det framgår av omtalen under den enkelte lokalitet, er det imidlertid påvist nye figurer på flere av lokalitetene i forbindelse med skjøtsel og dokumentasjon. Selv om de kan ha vært kjent fra tidligere, ble de fleste av skålgroplokalitetene hovedsakelig registrert på slutten av 1960-tallet i forbindelse med registreringer for Økonomisk kartverk. I Sola kommune ble de kontrollert på begynnelsen av 1990-tallet i forbindelse med 2.-gangsregistreringen for kartverket. I tillegg ble samtlige lokaliteter med figurer, og så å si alle med skålgroper, dokumentert på nytt i forbindelse med Riksantikvaren sitt nasjonale bergkunstprosjekt (1996 til 2005), jf. kulturminnebasen Askeladden.

I undersøkelsesområdet er det også funnet en rekke heller med ristninger og gropheller/-steiner fra graver. Så å si alle er innkommet til museet før 1940, mens løsfunn av steiner /heller som kan stamme fra graver har en litt større spredning i tid. Årsaken er nok at de store hauggravingenes tid, profesjonelt eller ureglementert, er forbi.

\subsection{Forvitring og nye motiv}

Kartlegging av i hvilken grad, og under hvilke forhold, bergkunsten forvitrer er og har vært et sentralt tema i forbindelse med de seinere års forvaltning. Registrering av status, dvs. bergart, oppløsningsgrad dokumentert ved tynnslip, registrering av «bommer» og avskallinger, har derfor vært en sentral oppgave i vårt arbeid på 2000-tallet.

I motsetning til ristningene på Åmøy (Høgestøl et al., 1999) og i stavangerområdet (Høgestøl et al., 2006), som hovedsakelig er hogd i fyllitt, er ristningene i Sola hogd i glimmergneis, ofte kvartsrik. På Særheim i Klepp er de ristet i gneis med innslag av glimmerskifer, på Husabø i Eigersund i gråbrun anortositt, mens ristningene i
Sokndal er hogd inn i gabbro. I alle bergartene er det innslag av mer lettoppløselige mineraler; dette er nøye beskrevet under omtalen av den enkelte lokalitet.

Alle figurene på lokalitetene ble gjennomgått med tanke på forvitring, og vi har tatt i bruk eldre fotografier, kalkeringer og innberetninger som sammenligningsgrunnlag. Alle figurer ble gjenfunnet, og det var ikke mulig å påvise endringer over tid. Dette kan selvsagt skyldes at enkelte eldre registreringer bygger på et relativt lavt detaljeringsnivå. På enkelte av lokalitetene ble det imidlertid påvist nye ristninger. I tillegg er det detaljer på enkelte av ristningene som er avvikende sammenlignet med tidligere dokumentasjon. På Ølberg III (id 14899) som ble oppdaget og kalkert og fotografert i 1992, ble det i 2009 oppdaget nok en figur, muligens en kropp med to bein (jf. Fig. 11), og i 2018 ble det påvist en mulig skipsog ringfigur. Alle figurene på Vigdel (id 34984) som ble kalkert og dokumentert i 1933, ble gjenfunnet, men etter at lokaliteten var renset for lav kunne en omtolke noen av figurene. I 2006 framkom en menneskefigur med hevede armer og med ei øks i den ene «hånda» (jf. Fig. 14, sml. Fig. 13). På Hellestø (id 44551) ble alle figurer som ikke er dekket av flygesand gjenfunnet. Tidligere er det funnet en hugget linje i øvre del av lokaliteten, i 2014 ble det funnet to nye skip samt et hjulkors, og ved nattfotografering i 2015 framkom solholdere over figurene nr. 17 og nr. 19 (se Fig. 23). I tillegg fikk figur nr. 2 en annen form (se Fig. 21). På Dysjaland (id 5528) er det hverken i originaldokumentasjonen fra 1948 eller ved seinere registreringer tatt med en fjerde figur på steinen, men den er notert i en linje i Johnsens magistergradsavhandling (1974). Figuren ble «gjenfunnet» i 2009 og tolket som en hest med mulig rytter (Fig. 32). Nylig ble en oppmerksom på at B. Myhre (1981, s. 99), også har omtalt figuren, her tolket som en oksefigur. På Håland i Klepp kommune (id 219216) der ulike felt ble dokumentert i 1933, ble det i forbindelse med fotografering i 2014 oppdaget en skipsfigur (muligens en til) like nedenfor skålgropfeltet, felt II. På Husabø (id 71931) i Eigersund kommune registrerte E. Eide (1993) deler av et mulig skip. Nyere gransking gjør det vanskelig å avgjøre om det er en reell ristning eller ikke, det må derfor fortsatt karakteriseres som en tvilsom originalristning. 
Så å si alle lokalitetene er i tillegg, med ulike metoder, undersøkt og kartlagt av geolog og konservator, og status på 2000-tallet er at lokalitetene i hovedsak er i god stand. På Ølberg II (id 14873) ble det påvist enkelte oppragende mineralkorn, men uten synlige skader. Det siger imidlertid vann over figurene, noe som kan føre til frostsprenging. På Haneberg i Sokndal (id 24715) kommenterer geologen at feltets overflate er solid uten sprekker og avskallinger, men noe ruglete på grunn av oppstående mineralkorn. Relieffet er like stort i og utenfor figurene, unntatt i deler av det sørøstligste skipet der linjene kan ha blitt polert i nyere tid. Ved fjerning av lav i 2006 ble det observert avskalling av 1-2 mm store fliser der laven var relativt tykk. Dette berørte ikke selve ristningene, men viser hvor viktig det er å holde ristningsfjellet lavfritt. Når det gjelder Bø i Sokndal (id 65874) observerte geologen at overflaten er ru på grunn av oppstikkende mineralkorn, men at det ikke ser ut til å være fare for avskallinger nær figurene. Konservator kommenterer også at overflata er kornete, men stabil. En naturlig sprekk går mellom figurene, her mener geologen at det ikke er fare for at avskallinger kan berøre figurene. Konservator observerte bommer og avskallinger langs sprekken og foreslår at en må vurdere konservering av denne for å hindre at avskallingene akselererer og til sist rammer figurene. På en av lokalitetene, Hellestø (id 44551) i Sola, var det imidlertid en viss faglig uenighet der konservator observerte eksfoliasjoner og mindre «bommer» over hele feltet, mens geolog konkluderte med at det forekommer en del mindre avskallinger ved linjene til noen figurer, men at dette kan stamme fra den gang figurene ble hogd; flere figurer er hogd gjennom en svak rustbrun forvitringsskorpe som er eldre enn figurene. Det ble videre registrert avskallinger like sør for noen av de nederste figurene, men konklusjonen er at fjellet for det meste virker temmelig solid der figurene er hugget. Tilstanden må derfor overvåkes jevnlig, og aktuelle tiltak settes i verk om nødvendig.

Alt i alt er tilstanden for lokalitetene i de områdene vi har undersøkt i forbindelse med dette arbeidet, i hovedsak stabil.

\subsection{Endring over tid og menneskeskapte skader}

Når det gjelder menneskeskapte skader, er to av de registrerte lokalitetene sprengt bort, begge var løse steiner; Ølbør I (id 34980) ble fjernet en gang mellom 1910 og 1933, og Håland felt I (id 219216-1), ble sprengt bort i 1966. Ellers har noen av lokalitetene vært utsatt for hærverk i form av hugginger på fjellflaten som f.eks. på Husabø (id 71931) der det alt i 1904 ble påpekt at «den er flittig brukt af nutidens ungdom til alskens navne», og i 1933 at fjellet er oversådd med monogrammer og nyere skipsfigurer «og ennu verre er at selve ristningene er opprisset», og ved ØK-registreringen i 1967 blir det notert at nedre figur (figur nr. 2) synes oppristet. I dag ses kun en dyrefigur ristet inn nederst på feltet. I etterkrigstida er det bygd en rekke hus i området, hærverket ser ut til å ha avtatt med dette. På Bø i Sokndal (id 65874) ble det i 1933 påpekt at midtpartiet på knausen er sprengt vekk, og at det står igjen en $15 \mathrm{~cm}$ høy vegg som tangerer en av gropene i gruppe 2. I 1967 ble det registrert at det er borehull i tre av gropene i samme gruppe, dette nevnes ikke i 1933. I 1933 blir det påpekt at i gruppe 3 der gropene ligger på hver side av en naturlig sprekk, er utvidet av mineskudd, dette blir ikke nevnt under registreringen i 1923. Lokaliteten har derfor blitt påført menneskeskapte skader, først i perioden 1923 til 1933 og deretter i perioden 1933 til 1967. Mht. til hærverk med maling kom det til museet i 1939 en melding om at noen gutter hadde malt på helleristningene på Haneberg (id 24715), mens den ovennevnte lokaliteten på Bø (id 65874) ble utsatt for det samme i 2006. Med unntak av de to lokalitetene som er sprengt bort, er lokalitetene i hovedsak påført mindre menneskeskapte skader, særlig tatt i betraktning lokaliseringen nær bebyggelse.

Bergkunsten har overlevd i flere tusen år med nokså uendret vegetasjon og miljø. Særlig de siste 50 årene er det kommet bebyggelse og trær rundt ristningene (se f.eks. Fig. 34a og 34b). Disse endringene er det lite å gjøre med, men det er viktig å holde vegetasjonen nede på og rundt lokalitetene. Skygge og løv skaper ugunstige forhold for ristningene, og røtter kan sprenge fjellet og figurene. Med jevnlig og riktig skjøtsel, vil det være mulig å bevare bergkunsten for generasjoner framover.

\subsection{Hvordan var miljøet rundt ristningene da de ble skapt?}

Som det framgår av dette arbeidet, er det lagt vekt på å undersøke hvor i landskapet bergkunsten er lokalisert samt hvordan miljøet rundt ristningene var da de ble skapt og utviklingen fram til i dag. Kunnskap om dette er sentral for forståelsen av ristningstradisjonen. Videre er ovennevnte også viktig for å kunne sette inn riktige tiltak i forbindelse med skjøtselsarbeid; å forsøke å gjenskape det miljøet rundt lokalitetene som medvirket til at bergkunsten er blitt bevart gjennom tusener av år.

Alle lokalitetene ligger innenfor kystlyngheiene. På Jæren var det en mosaikk av skogholt, gras og lynghei på det tidspunktet bergkunsten ble skapt, mens det ute ved kysten der ristningene finnes, var skogløst (Fig. 3). 
Miljøet rundt dem har i stor grad vært uforandret fram til rundt 1880 da de store uttappingene av vann og myrer startet opp. I dag fortoner landskapet seg ganske monotont, mens i bronsealderen var det større variasjon. Hele åtte vann har blitt tørrlagte ved drenering og ytterligere tolv vann har blitt senket på Jæren siden 1863 (BangAndersen, 1985, s. 58). I Sokndal og Eigersund kommuner var imidlertid landskapet ikke blitt helt skogløst i samme tidsperiode, avskogingsprosessen ble ikke sluttført før om lag $200 \mathrm{f}$.Kr.

I motsetning til ristningene i stavangerområdet (jf. Høgestøl et al., 2006) er det kun to av lokalitetene i Sola kommune, Vigdel (id 34984) og Hellestø (id 44551), som har en beliggenhet nær sjøen. Selv om vannstanden har vært høyere og tilknytningen til havet har vært enda mer framtredende enn i dag, er figurene på disse lokalitetene, i motsetning til flertallet i stavangerområdet ikke vendt mot sjøen, men mot land. Dvs. for de som utførte og/ eller deltok i ritualer, fører denne lokaliseringen til at en kunne se figurene og sjøen samtidig, mens det mest vanlige for øvrige lokaliteter har vært at en har betraktet figurene med ryggen mot sjøen. Om dette er bevisst lokalisering, eller om andre forhold som f. eks. egnete ristningsflater har spilt inn, er vanskelig å avgjøre i dag. Sammenhengen mellom vann og lokalisering har imidlertid vært viktig, og som det framgår av Fig. 6, ligger de øvrige seks lokalitetene i Sola k., hovedsakelig nær tidligere vann og myrområder. Slik landskapet var før uttapping og drenering, har det kanskje ikke vært til å unngå, men plasseringen virker likevel bevisst. F.eks. har Dysjaland III (id 14884) ligget på et eid mellom Harvalandsvatnet og Skadsvatnet. Sistnevnte har fungert som en ferdselsåre innover jærlandskapet. At elver og vann har hatt stor betydning, framkommer også ved de eldre bronsealderhaugenes plassering i landskapet der mange er konsentrert til vad, på begge sider av elveløpene og på rygger langs vannene (L. N. Myhre, 2004; PrøschDanielsen et al., 2018). Unntaket er Kråkhaug (id 65851) som riktignok har vært plassert nær ei lita myr, men her er det vidt utsyn, bla. mot det uttappete Skadsvatnet og mot Harvalandsvantet. Ristningene på Håland i Klepp (id 219216) er også nært knyttet til tidligere vann og myrområder, mens ristningssteinen på Særheim (id 5288) har vært lagt ned i ei lukket grav. Ristningene i Sokndal (id 24715, id 65874) er plassert nær elva (se Fig. 49), mens ristningene på Husabø (id 71931) i Egersund er unntaket, lokaliteten ligger langt fra sjø og vann. Dog kan sjøen skimtes mot sør.

Verd å merke seg i denne sammenhengen er at store områder som lå under vann i yngre steinalder ble tørrlagte i løpet av bronsealderen, og førte til næringsrike beiteområder (jf. Fig. 35b og Fig. 35c). Dette kan være en av forklaringene på bronsealderrikdommen i Klepp og Sola kommuner. Imidlertid, dette økte faren for sandflukt fordi ved ytterkysten er løsmassene eksponerte for vind og bølgeaktivitet.

Som nevnt innledningsvis er beskrivelse av landskapet slik det var da ristningene ble skapt, og deres lokalisering, viktig for tolkingen og forståelsen av fortidens religion og riter. Dette vil bli nærmere behandlet i kapittel 10.2. 


\section{Bergkunstfeltene - motiv, datering og tolkning}

\section{I Motivene på de åpne bergkunstlokalitetene}

Sammenlignet med de øvrige lokalitetene i stavangerområdet som utgjør et flertall både når det gjelder antall lokaliteter (jf. Fig. 1) og figurer, har figurtypene i Sola og Sokndal kommuner større variasjon. Menneskefigurer opptrer sjelden på ristningene i Rogaland. På de om lag 1000 figurene på Åmøy i Stavanger k. er det registrert ni sikre og mulige frittstående menneskefigurer samt to frittstående adoranter på Fluberget i Stavanger k. (ellers er det selvsagt mannskapsstreker, adoranter, lurblåsere og «brudepar» i skipene). På lokalitetene i Sola er det frittstående menneskefigurer på Vigdel, Kråkhaug, Dysjaland I og muligens Ølbør III, til sammen seks eller sju. På flere av skipene i Rogaland er det tydelige hestehoder i stavnen, men det er kun i Sola k. at det er påvist enkeltstående hester: på Ølbør III og Dysjaland II, til sammen tre stykker. Muligens kan også en av figurene på Vigdel tolkes som en hestefigur. Av andre dyrefigurer er det registrert et firbeint dyr på henholdsvis Åmøy I og VI, mens på Kråkhaug er det påvist to (hvorav den ene muligens er en hest). I tillegg kommer gjeterscenen på Dysjaland II med fire sauer og en hund. Fuglefigurer er det få av i Rogaland, på Åmøy I er det registrert en fugl, muligens en svane. På Ølbør III kan kanskje en av figurene tolkes som en mulig fugl. Mulige slangefigurer er påvist på Åmøy VI-5 og på Tasta, Stavanger k. I vårt undersøkelsesområde kan figurer på Bø i Sokndal og Ølberg III i Sola også tolkes i samme retning. Lokalitetene er ofte kaotiske med figurer i alle retninger, ofte overhogde. Selv om plasseringen neppe er tilfeldig, er det ofte vanskelig for oss i dag å tolke hva de uttrykker og hva risterne har ønsket å formidle. I Sola er det imidlertid tre scener - gjeterscenen på Dysjaland, scenen på Kråkhaug der et profilmenneske (uten hode) med hevet øks står over fire menneskefigurer samt menneskefiguren på Vigdel som står med løftete armer med ei øks i den ene handa over de fire dype og breie strekene nedenfor, som kan tolkes som stiliserte menneskefigurer. Bergkunsten i Sokndal, og særlig på Bø, har et annet uttrykk enn de øvrige ristningene i Rogaland. Linjene er bredere og mykere i formen. Også E. Fett og P. Fett (1941, s. 94) påpeker at skipstypene har et noe annet preg enn de øvrige ristningene i Rogaland. Øksa i stavnen på skip nr. 2 på Hanaberglokaliteten er som E. Fett og P. Fett påpeker, enestående i Rogaland (1941, s. 95).

I vårt undersøkelsesområde er det også flere spesielle skålgroplokaliteter. Spesielt kan nevnes lokalitetene på Håland i Klepp der det fantes om lag 75 skålgroper og ett skip på ei flyttblokk der spredningen av gropene kan nærmest minne om en stjernehimmel, samt de 42 små gropene plassert tett i tett og der det er hogd ett sikkert, (muligens ett skip til) like nedenfor. Lokaliteten med minst 90 skålgroper på Husabø i Eigersund, og de mange dype og breie skålgropene på de to lokalitetene i Sokndal, er også særegne.

Verd å merke seg er at på seks lokaliteter med skipsfigurer, er det også skålgroper (Ølbør III, Kråkhaug, Håland felt I og II, Haneberg og Bø). På fem av dem er det tydelig at skålgropene inngår i komposisjonen; så å si samtlige svever over skipene. Unntaket er Kråkhaug hvor det kun finnes ei grop som er plassert til høyre for ett av skipene. En må anta at disse skålgropene har samme datering som skipsfigurene.

Fire av skålgroplokalitetene i Sola k. og en i Sokndal k. ligger innenfor fornminneområder datert til jernalder. Om det er en samtidig datering, særlig for lokalitetene i Sola, er imidlertid vanskelig å avgjøre.

Samlet sett skiller ristningene i vårt undersøkelsesområde seg i stor grad fra de øvrige i Rogaland når det gjelder lokalisering, figurtyper og komposisjoner.

\subsection{Datering og tolkning}

Datering av figurer på åpne lokaliteter er komplisert. Strandlinjer kan i noen tilfeller nyttes for å gi en bakre datering (se f.eks. Ling, 2014), og sammenligninger med dekor på gjenstander, eller på stein og heller fra sikre kontekster, har vært en utbredt dateringsmetode. Særlig gjelder dette for utvikling av skipsfigurenes typologi og kronologi (se f.eks. Kaul, 1998). Da det ofte er stor geografisk avstand mellom gjenstandens opphavsområde og bergkunstens lokalisering, kan det være forskjell i tid. En kan heller ikke vite om formen på figurene på de åpne lokalitetene er inspirert av dekoren på gjenstandene eller motsatt. Tradisjonsforskjeller mellom ulike geografiske områder gjør at datering basert på gjenstandsmateriale, eller ved 
Tabell I. Datering av bergkunstfelt med figurer i undersøkelsesområdet.

Table I. Dating of rock art sites in the investigated area. $B A=$ Bronze Age, EBA = Early Bronze Age, $L B A=$ Late Bronze Age, IA=Iron Age

\begin{tabular}{|c|c|c|}
\hline Lokalitet/Locality & Datering/Date & Antall figurer/Number of figures \\
\hline «|bør |», Sola & Eldre bronsealder/EBA & 7 skip/7 ships \\
\hline «Ølbør Il», Sola & Eldre bronsealder/EBA & 2 skip/2 ships \\
\hline «Ølbør III», Sola & Yngre bronsealder/LBA & Minst 20 figurer. Skip, hest, solholder mm/at least 20 figures. Ships, a horse, sun holder, etc. \\
\hline Vigdel, Sola & $\begin{array}{l}\text { Hovedsakelig yngre } \\
\text { bronsealder/ } \\
\text { mainly dated to LBA. }\end{array}$ & $\begin{array}{l}\text { Minst } 28 \text { figurer. Skip, menneske med øks mm/at least } 28 \text { figures. Ships, a man holding an } \\
\text { axe, etc. }\end{array}$ \\
\hline Hellestø, Sola & $\begin{array}{l}\text { Hovedsakelig yngre } \\
\text { bronsealder/ } \\
\text { mainly dated to LBA. }\end{array}$ & Minst 30 figurer. Skip, hjulkors mm/at least 30 figures. Ships, wheel-cross, etc. \\
\hline «Kråkhaug I», Sola & Yngre bronsealder/LBA & 16 figurer. Skip, menneske-dyrefigurer/l 6 figures. Ships, human and animal figures \\
\hline «Kråkhaug Il», Sola & Bronsealder/BA & 30 figurer, hovedsakelig skålgroper/30 figures, mainly cup marks \\
\hline Dysjaland I, Sola & Yngre bronsealder/LBA? & $\begin{array}{l}6 \text { figurer (I menneske, } 5 \text { dyrefigurer), gjeterscenen/ } 6 \text { figures (I human with } 5 \text { animals), } \\
\text { herder scene }\end{array}$ \\
\hline Dysjaland II, Sola & Yngre bronsealder/LBA? & 4 figurer. Ringer, hest, menneske?/4 figures. Rings, a horse, probable a human \\
\hline Dysjaland III, Sola & Bronsealder/BA & I sirkel// circle \\
\hline «Steinhaug», Klepp & Bronsealder/BA? & 2 fotsåler, 12 skålgroper $/ 2$ footprints, 12 cup marks \\
\hline Håland I, Klepp & Yngre bronsealder/LBA & I skip, 75 skålgroper/I ship, 75 cup marks \\
\hline Håland II, Klepp & $\begin{array}{l}\text { Yngre bronsealder/førromersk } \\
\text { jernalder/LBA/IA }\end{array}$ & I-2 skip, ca 40 skålgroper/ I-2 ships, ca. 40 cup marks \\
\hline Husabø, Eigersund & Eldre bronsealder/EBA & 2 skip/2 ships \\
\hline Haneberg, Sokndal & $\begin{array}{l}\text { Yngre bronsealder/førrromersk } \\
\text { jernalder/LBA/IA }\end{array}$ & 2 skip, 68 skålgroper/2 ships, 68 cup marks \\
\hline Bø, Sokndal & $\begin{array}{l}\text { Yngre bronsealder/førromersk } \\
\text { jernalder/LBA/IA }\end{array}$ & $\begin{array}{l}7 \text { figurer. } 5 \text { skip, linjer, mulig fotsåle, } 3 \text { skålgroper, } 2 \text { nærliggende skålgropfelt/ } 7 \text { figures. } \\
5 \text { ships, lines, probable footprint, } 3 \text { cup marks, } 2 \text { separate concentrations of cup marks nearby }\end{array}$ \\
\hline
\end{tabular}

sammenligninger mellom ulike geografiske områder, må brukes med en viss forsiktighet.

Datering av bergkunstlokalitetene i dette arbeidet bygger hovedsakelig på Mandt sitt klassifikasjonssystem utviklet på basis av materialet i Sogn og Fjordane og på Sunnmøre (1991), og Wrigglesworth (2011) sitt arbeid med ristningene i Hardanger og Sunnhordland. Dette pga. den geografiske nærheten til Rogaland. Ellers er det i noen grad skjelt til Ling (2014) og Kaul (1998) sine skjema for utvikling og datering av skipstyper.

Skålgroper er den mest tallrike og den enkleste formen for bergkunst, og dateringen spenner fra steinalder til middelalder (se bla. Lødøen, 2015, s. 228). Det er ikke gjort forsøk på å datere dem i dette arbeidet, men der det finnes skålgroper på samme flater som figurer, er det rimelig å anta samtidighet.

Som det framgår av tabell 1, kan tre lokaliteter dateres til eldre bronsealder, ti med stor sannsynlighet til yngre bronsealder, mens tre ikke kan dateres nærmere enn til bronsealder. Selv om lokalitetene er begrenset i antall, er flertallet fra yngre bronsealder, noe som er i overensstemmelse med fordelingen i Sør-Norge. Så vel Johnsens (1974, s. 136-139) diskusjon av dateringsspørsmål for Rogaland som Mandts (1991, s. 299) for Sunnmøre og Sogn og Fjordane indikerer at tyngdepunktet for ristningsproduksjonen «ligger trolig mellom midten av bronsealderens periode 3 til slutten av periode 5» (Mandt, 1991, s. 338). Vogt (2012) mener også at storparten av lokalitetene i Østfold kan dateres til yngre bronsealder.

I tillegg til ulik datering (Tabell 1 og 2) framgår det også at lokaliseringen av åpne felt og gravristninger i hovedsak ekskluderer hverandre geografisk. Begge disse observasjonene er da også registrert og omtalt tidligere (Kjeldsen, 2002; Prøsch-Danielsen, 2002; Syvertsen, 2003). Fig. 1 viser med all tydelighet hvordan antall åpne 
Tabell 2. Datering av gravristninger (bygger i hovedsak på Syvertsen, 2003).

Table 2. Dating of slabs (mainly based on Syvertsen, 2003). BA = Bronze Age, EBA = Early Bronze Age, LBA = Late Bronze Age

\begin{tabular}{|c|c|c|}
\hline $\begin{array}{l}\text { Gård/kommune/museums nummer/ } \\
\text { Farm/municipality/museum no. }\end{array}$ & Datering/Dating & Motiv/Motifs \\
\hline Myklebust, Sola S269 & Eldre eller yngre bronsealder/BA & Fotsåler, skålgroper/footprints, cup marks \\
\hline Myklebust, Sola S270 & Eldre bronsealder/EBA & Skålgroper/cup marks \\
\hline Myklebust, Sola S27I & Eldre bronsealder/EBA & Skålgroper/cup marks \\
\hline Nord Kolnes, Sola S6656 & Eldre bronsealder/EBA? & Skålgroper (2 heller)/cup marks (2 slabs) \\
\hline Rægje, Sola, id 72347 & Eldre bronsealder/EBA & Spiral, ring, skålgroper/spiral, ring, cup marks \\
\hline Rægje, Sola SI I 921 & Eldre bronsealder/EBA & Skipsfigurer, fotsåler, skålgroper/ships, footprints, cup marks \\
\hline Rægje, Sola S6502, & Eldre bronsealder/EBA? & Skålgroper, fra gravhaug!/cup marks, from a burial mound? \\
\hline Rægje, Sola B4054 & Eldre bronsealder/EBA? & Skålgroper, fra gravhaug!/cup marks, from a burial mound? \\
\hline Anda, Klepp & Bronsealder/BA & Skålgroper (tapt)/cup marks (now missing) \\
\hline Anda, Klepp & Eldre bronsealder/EBA? & Skålgroper (tapt)/cup marks (now missing) \\
\hline Særheim, Klepp S9633aq & Uviss/Unknown & Skålgroper ( 12 heller)/ cup marks ( 12 slabs) \\
\hline Nese, Klepp S9785 & Bronsealder/BA & Skålgroper, sirkel/cup marks, circle \\
\hline Erga, Klepp & Eldre bronsealder/EBA? & Skålgroper (tapt)/cup marks (now missing) \\
\hline Erga, Klepp S4555 & Uviss/Unknown & Skålgroper/cup marks \\
\hline Hodne, Klepp S3506 & Eldre bronsealder/EBA & Vinkel- og horisontale linje/angled and horizontal lines \\
\hline Hodne, Klepp S4I58 & Eldre bronsealder/EBA & Konsentriske sirkler/concentric circles \\
\hline Borsheim, Klepp B56II & Eldre bronsealder/EBA & Horisontale linjer, spiral/horizontal lines, spiral \\
\hline Borsheim, Klepp S4036 & Eldre bronsealder/EBA? & Skålgroper (2 heller)/cup marks (2 slabs) \\
\hline Austre Bore, Klepp S6020m & Eldre bronsealder/EBA & Skålgroper/cup marks \\
\hline Austre Bore, Klepp S6I43 & Eldre bronsealder/EBA & Skålgroper/cup marks \\
\hline Austre Bore, Klepp $\$ 6655$ & Eldre eller yngre bronsealder/BA & Skålgroper/cup marks \\
\hline Re,Time B4820d & Eldre bronsealder/EBA & Skålgroper/cup marks \\
\hline Re,Time S5035d,e,g & Uviss/Unknown & Skålgroper/cup marks \\
\hline Re, Time & Eldre bronsealder/EBA & Skålgrop (tapt)/cup mark (now missing) \\
\hline Hognestad,Time S9784 & Eldre bronsealder/EBA & Skålgroper/cup marks \\
\hline Auglend, Time S2405 & Eldre bronsealder/EBA & Buer og linjer/curves and lines \\
\hline Søyland, Hå S4452 & Eldre bronsealder/EBA & Buer og linjer/curves and lines \\
\hline Nølstad, Hå S4630h & Yngre bronsealder?/LBA? & Skålgroper (stein)/cup marks (block) \\
\hline
\end{tabular}

ristningslokaliteter dominerer i stavangerområdet og på de sørligste ryfylkeøyene, og de er hovedsakelig lokalisert nær sjøen, mens løse heller med groper og figurer samt gravristninger dominerer på Midt-Jæren. Sola k. står imidlertid i en særstilling med gravristninger i tillegg til åpne ristninger fra så vel eldre som yngre bronsealder. Ulikheter i erverv, økonomi, topografi, geologi og datering er noen av de forklaringene som blir brukt for å forklare hvorfor ristningene i de to områdene er forskjellige.
Mangelen på fjell kan f.eks. forklare hvorfor de åpne ristningene i liten grad forekommer på Midt-Jæren, men det forklarer ikke hvorfor ristninger på heller og steiner i graver i mindre grad er påvist innenfor de åpne ristningenes område. På den annen side - på Karmøy med nok fjell å hogge i, finnes de store bronsealderhaugene, Rehaugene, også kalt Blodheia, og på Bokn store bronsealderhauger langs leia; på Karmøy er det kun registrert en enslig ringfigur, et lite skip som kan være hugget i nyere tid samt to 
lokaliteter med henholdsvis to og fire groper, og på Bokn er ingen bergkunstlokaliteter hittil registrert.

En annen forskjell mellom gravhellene og de åpne ristningene er hvem de er beregnet på. Som Syvertsen (2003) har påpekt, er gravhellene private, de er synlige for et fåtall mennesker ei kort stund, mens de åpne ristningene er offentlige og synlige også for ettertiden, m.a.o. markører av det individuelle til forskjell fra det kollektive. Denne tendensen framkommer også når det gjelder de åpne lokalitetene. Som Vevatne har påpekt $(1996,2002)$ er det i eldre bronsealder gjennomgående færre figurer på mindre flater, mens i yngre bronsealder er det flere figurer hugget på større bergflater og ofte plassert nær ferdselslinjer. De sistnevnte har nok vært samlingsplasser for større grupper, men de små har vært beregnet på mer private samlinger. En annen ulikhet er figursammensettingen på gravhellene finnes få figurtyper sammenlignet med de åpne lokalitetene. Samme tendens framgår i vårt materiale. Ølbør I og II i Sola k. samt Husabø i Eigersund k. som dateres til eldre bronsealder, inneholder alle skip, og antallet er fem på førstnevnte (en helhetlig komposisjon), mens de to sistnevnte kun inneholder to skip. Videre, så å si samtlige lokaliteter datert til yngre bronsealder ligger ved sjø eller ferdselsveier.

At det eldre bronsealdersamfunnet med bakgrunn i økende stratifisering i løpet av seinneolitikum var et hierarkisk samfunn, viser de mange storhaugene/røysene og metallgjenstandene. Rikdommen på Midt-Jæren, f.eks. kommer en stor del av alle bronsene på Vestlandet fra Klepp kommune, må ha blitt bygd opp gjennom økonomisk overskudd, kontakter og vareutveksling, og der bronse ble sett som det ypperste prestisjesymbolet. Sentrale deler av Rogaland har høyst sannsynlig inngått $i$ et felleseuropeisk nettverk der hovedforbindelsen gikk til Jylland. Ved inngangen til yngre bronsealder ble forbindelsen mer eller mindre brutt pga. regresjon i dette området; det kulturelle tyngdepunktet ble i hovedsak flyttet fra Jylland til de danske øyene, noe som førte til at tyngdepunktet her til lands ble forflyttet til Øst-Norge (Johansen, 1981, s. 92). Konsekvensen ser ut til å være at Midt-Jæren mister sin økonomiske og sosiale posisjon. I hele Sør-Skandinavia skjer det også en ideologisk endring, de store gravhaugenes tid er forbi, gravene blir funnfattigere, begravelsene skjer ofte som sekundærbegravelser i eldre storhauger og en vanlig oppfatning er at utviklingen går mot et mer egalitært samfunn. Dette gjenspeiles bl.a. i bergkunstmaterialet der det som tidligere nevnt skjer en endring fra det private og individuelle til det kollektive og offentlige. Selv om de figurrike lokalitetene på Austre Åmøy (Kjeldsen, 2005) og Fluberget kan dateres til både eldre og yngre bronsealder, kan en stille spørsmål om hvorfor ristningstakten øker, hvorfor blir stavangerområdet og de sørligste ryfylkeøyene et sentralområde for religionsutøvelse? Hvilke lokale forhold kan ha påskyndet denne utviklingen?

I tillegg til at vareutvekslingen med Jylland fikk mindre betydning, har Prøsch-Danielsen (2002) tidligere foreslått at det kan ha skjedd omlegging av driften til økt husdyrhold og økt utnytting av utmarksressursene på Midt-Jæren ved begynnelsen av yngre bronsealder. Om lag 800 f.Kr. var Midt-Jæren helt avskoget, og i motsetning til områdene lenger nord der prosessen tok om lag 4000 år, skjedde den relativt brått i dette området. Med skogen forsvant en del gjødningsstoffer, og intensiv bruk kan ha ført til ytterligere utpining av jorda. Sandflukt langs ytterkysten kan også ha vært en medvirkende årsak. Kanskje er dette årsaken til at prosesjoner og pløyescener mangler helt i rogalandsmaterialet; vår eneste jordbruksscene er gjeteren med husdyr og hund på Dysjaland. Muligens resulterte dette i at maktsenteret, i alle fall det religiøse, ble flyttet nordover til områder der det var muligheter for utøvelse av religiøse aktiviteter knyttet til lokaliteter, hugget inn på store bergflater og beregnet på kollektive ritualer, nær ferdselsveier (sjøen) og ved lune havner.

Med andre ord kan brutte vareutvekslingsforbindelser, kombinert med utpining av jorda/omlegging av driftsformen, delvis forklare ovennevnte endringer i vårt undersøkelsesområde.

Riter og myter i bronsealderens religion er ofte blitt knyttet til avlekult og dyrking av sola og solguder; riter og myter knyttet til dette er felles for store deler av Europa, Egypt og Midt-Østen. I Nord-Europa, og særlig da i Skandinavia, fikk dette sitt eget ikonografiske uttrykk. For god grøde er vann i tillegg til sol et viktige element. Dette gir mening til ristningenes lokalisering nær og mot vann, myrer, elver og ikke minst havet. Skipet er et gjennomgående symbol på så å si alle lokaliteter i vårt undersøkelsesområde. De har vært tolket og kan tolkes på ulike måter (se avsnitt 2.4 vedrørende strandforskyvning i dette arbeidet), men å knytte dem til myten om solens reise kan være plausibelt (Kaul, 2004). Sola reiser over himmelen og går ned i vest, forsvinner i havet, ferden går så videre under havet til den igjen står opp i øst - et evig kretsløp. For å hjelpe sola på sin ferd ble det laget myter og riter knyttet til et dagskip som trekker sola mot vest, og et nattskip som trekker den under havet mot øst. Skipets hjelpere kan igjen bl.a. være hesten og slangen. I vårt undersøkelsesområde (se omtale under den enkelte lokalitet), og i Rogaland generelt, kan en slik tolking gi mening: Vi har skip som vender både mot høyre og venstre (på enkelte lokaliteter kun dag- eller nattskip, på andre i begge retninger), ringfigurer (solsymboler) som 
er knyttet til skipet eller selvstendige symboler, hester, «solholder» m.m. Bronsealderens religion ser ut til å vært nokså ens gjennom hele perioden, men en utvikling mot et mer egalitært samfunn i yngre bronsealder førte til at flere fikk anledning til å delta i religionsutøvelsene (se argumentasjon i Kaul, 2004, s. 369). I vårt område kommer dette som tidligere nevnt til uttrykk gjennom en utvikling fra gravristninger beregnet på få, og lokaliteter med få figurer, til større, åpne felt. Endring i gravskikk med store gravminner, mot enklere gravskikk, kan også understøtte dette.

Men hvorfor økte ristningsaktiviteten ved overgangen til yngre bronsealder? Det har vært satt i forbindelse med økonomiske eller sosiale endringer der ustabilitet kan ha ført til økt behov for religiøse aktiviteter (Vevatne, 1996, s. 119-120 med henvisninger). I tillegg til endringer i vareutvekslingsnettverket, og mer overordnete samfunnsendringer, kan også andre hendelser ha ført til utrygghet. Nærliggende er å trekke inn det kraftige vulkanske utbruddet i Hekla III ved overgangen til yngre bronsealder. Selv om konsekvensene av dette utbruddet er ukjent innenfor vårt område, kan eventuelle askeskyer i seg selv ha ført til uro og frykt i befolkningen. Selv om det er stor avstand i tid og rom, har en fra nyere tid god dokumentasjon på konsekvensene av større utbrudd; f.eks. var «the year without summer» i 1816 som særlig berørte Europa og Nord-Amerika, men også andre deler av verden, et resultat av vulkanen Tambora i Indonesia sitt utbrudd i 1815 (H. Stommel \& E. Stommel, 1979). Kulden førte til ødelagte avlinger med derpåfølgende hungersnød og folkeforflyttinger. Først i 1819 kom verdensklimaet tilbake på normalt nivå. Videre, den lille istiden som varte fra 1300 til 1800-tallet var særlig streng på 1600-tallet. Årsaken til klimaforverringen i denne 500 år lange perioden var først og fremst lavere solaktivitet, men tolv vulkanutbrudd i Stillehavsområdet fra 1638 til 1644 gjorde ikke klimaet bedre. Det finnes skriftlige kilder på at sola var blek og skylagene mørke. Konsekvensen var sult, en rekke borgerkriger i hele Europa, opprør og hekseprosesser (Ljungquist, 2009). Som en av flere faktorer har også flere forskere i den seinere tid knyttet «The Dust Veil», datert 536-7 e.Kr. som resulterte i en lengre kuldeperiode, til de sosiale og økonomiske endringene som fant sted i overgangen mellom eldre og yngre jernalder (Iversen, 2016).

Selv om et utbrudd i seg selv neppe fører til økonomiske og sosiale endringer av et samfunn (se diskusjon i Buckland et al., 1997; Plunkett, 2006), kan konsekvensen av et utbrudd som førte til, om enn kortvarig, temperaturfall, skygge for sola og mørke skyer være en akselerering i dyrkinga av sola som livgivende kraft, det kollektive blir viktigere enn det individuelle og ristningsaktiviteten forflytter seg til områder med store ristningsflater der det er rom for større kollektive samlinger. Lokaliseringen nær havet (beliggenheten er ofte nær datidens strandkant) kan også ha sammenheng med myten om solens reise fra lokalitetene kan man betrakte soloppgang og nedgang; beliggenheten er tvetydig - mellom himmel og hav.

På lokalt plan mistet Midt-Jæren ved overgangen til yngre bronsealder sin dominerende posisjon. Samtidig, i bronsealder, var Sørvest-Norge en del av et økonomisk og kulturelt skandinavisk og europeisk fellesskap der endringer ved overgangen til yngre bronsealder, dvs. mot et mer egalitært samfunn og større religiøs demokratisering, også kan etterspores i vårt område. De store gravhaugenes tid med gravristninger beregnet på de få er forbi, og i vårt område manifesterer endringene seg ved at ristningstakten økte med større ristningsflater og flere figurer. Nå var det vulkanutbrudd en tid før eldre bronsealder (Hekla IV) og i eldre bronsealder (Hekla SV) som også kan ha hatt innvirkning på dyrking av sola som livgivende kraft, men behovet for økt religiøs aktivitet i vårt område kan forklares med at flere faktorer, som f.eks. sosiale og økonomiske endringer, i større grad enn i eldre bronsealder, inntraff samtidig.

\section{SUMMARY}

One of the largest collections of rock art in Norway can be found in Rogaland County: sites with figures (35), sites with figures and cup marks (25) and sites with cup marks only (51). In addition, there are 38 grave monuments with a total of 67 ornamented slabs and/or stones with cup marks as well as 37 stray finds. Many of these stray finds may originate from graves.

This paper deals with the central and southern parts of Jæren and the region of Dalane in Rogaland. This part of Rogaland comprises 15 localities with figures and cup marks, 20 with cup marks only and 43 sites with a total of 61 slabs and stones with motives and cup marks that originate from, or may originate, from graves (Fig. 1).

Sites with figures and cup marks were surveyed between 1902 and 1992, while sites with cup marks only were mainly registered in the $1960 \mathrm{~s}$. Most of the rock carvings from grave monuments were introduced into the museum's collection prior to 1940.

The paper presents the history of these sites, when they were surveyed and registered, as well as an overview of variations in motives. The Bronze Age environment around the rock art sites is also described. Geological conditions, vegetation history and localization are key factors in understanding the rock art tradition. 
Rock art is objects in nature similar to the objects in the museums; description of the bedrock, the degree of weathering, change over time as well as man-made damage have therefore been part of the investigations.

The bedrock in the Jæren region belongs to the Caledonian nappe complex. While rock art sites in the northern part of Jæren are carved in soft phyllite, those in the central part of Jæren are gneisses primarily composed of quartz, albite, muscovite, biotite and carbonate (Fig. 2a). The southern part of Jæren is covered by thick Quaternary deposits (Fig. 2b), and thus, bedrock is not exposed. The lack of exposed bedrock implies that rock art sites are missing southwards. Ornamented slabs are recorded, but these also thin out as one moves southwards across Jæren. Rock art sites in the Dalane region are tied to the anorthosite province that is divided into several massifs. In the Eigersund area the figures are found in the Eigersund-Ogna intrusion, while in the Sokndal area they are tied to the Bjerkreim-Sokndal intrusion.

In this study, a geologist and a curator have surveyed all rock art sites with figures. In the northern part of Jæren, where phyllite dominates, weathering of the bedrock and of the rock art motives is a problem at some sites. Figures are heavily eroded and some have nearly disappeared, primarily due to temperature variations and frost action. In our study area, this does not seem to be a problem and the main conclusion is that the rock surface is stable. However, thin-sections of the bedrock show some fractures and dissolution pores. Overgrowth with lichens and mosses is a constant problem that must be addressed every year by applying ethanol to the figures and the surrounding bedrock surface.

Today, the rock art sites in Rogaland belong to the coastal heath section, with a few exceptions. Some cupmark sites are exposed further inland in the Eigersund and Sokndal municipalities and close to the sea in the inner ford district in the Vindafjord, Sauda and Suldal municipalities (Fig. 1). All these exceptions seem to be tied to lines of communication. It has been recorded that the coastal heathland is anthropogenic in origin, intentionally created to serve as pastures throughout summer and winter, as Calluna, the major constituent, is evergreen.

The coastal heath section is characterized by an oceanic climate with mild winter temperatures, where the 0 ${ }^{\circ} \mathrm{C}$ January-isotherm marks the inner eastern limit. This limit also determines the inner limits for the rock art sites. Palynological studies in Rogaland have recorded that forest clearance spanned over 3600 years, but with three major clearance phases; 4000-3600 BC (Mesolithic/Early Neolithic transition), 2500-2200 BC (Middle Neolithic
II/Early Late Neolithic transition) and the last 1900-1400 BC (Late Neolithic to Bronze Age Period II). The forest clearance started in the western coastal areas and proceeded inland and eastwards. By 900-700 BC (Bronze Age Period V), the whole Jæren region had become a heathland landscape. The majority of the ornamented grave slabs are dated to Early Bronze Age, while rock art sites carved on exposed bedrock cover both the Early and Late Bronze Age. This implies that all sites in the Jæren area were carved in a treeless heathland. In the Sokndal and Eigersund area the forest clearance process was not complete until 200 BC. Here the landscape was still a mosaic of forested areas, heathland and grassland when the rock art was carved.

Today, the landscape in Jæren is a quite monotonous agricultural landscape, mainly grassland and pastures. Some cultivated fields are recorded in Mid-Jæren. Since 1880, eight lakes have been drained, 12 lakes has been lowered and several mires/bogs have been cultivated and drained. The environmental setting, especially in the Jæren region, has thus changed dramatically since the Bronze Age. This implies that some rock art sites that were maritime related or tied to mires and lakes in the Bronze Age appear completely out of context in the modern landscape. In this paper, therefore, importance has been placed on understanding and figuring out what these changes imply. Alongside these man-made environmental changes, the sea-level changed from approximately $+5 \mathrm{~m}$ to the present sea-level (Fig. 4a). This natural lowering of the sea-level, or uplift of the land, has also changed the landscape. The coastal rim has increased since the Bronze Age, and this implies that several natural harbours that existed in the Bronze Age, as well as characteristic river-inlets, have disappeared. Quaternary deposits were exposed by the lowering of the sea-level. Together with an increase in agricultural activity, this caused sand drift along the coast. Rock art localities thus might be hidden underneath these sand layers.

Compared with the northern part of Jæren and the southernmost part of the Ryfylke islands (Stavanger area), the number of carvings on exposed bedrock and the number of figures on each site are fewer in our study area (see Fig. 1, Høgestøl et al., 1999, Høgestøl et al., 2006). On the other hand, there is a greater variation in the motives. Ships dominate here as well as in Rogaland generally, but there are also human figures, horses, sheep, dogs and other four-legged animals, as well as possible birds and snake figures. Furthermore, the ship with an axe in the bow, at Haneberg, Sokndal, is unique in Rogaland (Fig. 44). 
In Rogaland it is often difficult to see a pattern or to identify potential correlations between figures on a panel. In Sola municipality, however, there are three scenes: the herd scene at Dysjaland (Fig. 29), the «intercourse» or the «bridal scene» at Kråkhaug (Fig. 26) and the human figure at Vigdel, with raised arms holding an axe above four deep and broad lines, interpreted as stylized human figures (Fig. 14). The figures at Bø, Sokndal (Fig. 45), with their "soft" shapes, have a distinct character compared to the other rock carvings in Rogaland.

Several of the cup mark sites are also remarkable, for example the cup mark sites at Håland, Klepp where the cups on panel II are placed close together (Fig. 38), and panel I, reminiscent of a starry sky (Fig. 37). Furthermore, wide cup marks are more common in Sokndal than anywhere else in Rogaland (Fig. 46).

With reference to Fig. 1, there is a difference in the distribution of various types of rock art where carvings on exposed bedrock dominate in the Stavanger area, while the majority of decorated slabs/stones from graves and stray finds are most common in the central part of Jæren. In the region of Dalane, the carvings on exposed bedrock are once again dominant (the two red dots, cf. Fig. 1, are stray finds and do not originate from graves). Furthermore, the datings, cf. Tables 1 and 2, fall into two groups. The majority of the rock carvings on exposed bedrock can be dated to the Late Bronze Age (which is usual throughout Western Norway), while ornamented grave slabs/stones with cup marks are essentially dated to Early Bronze Age. The lack of exposed bedrock in the central and southern part of Jæren may explain the absence of carvings on bedrock, but it does not explain why there are fewer numbers of ornamented slabs and stones with cup mark outside the central (and southern) part of Jæren.

Who was the rock art designed for? The ornamented grave slabs are private, visible to only a few people for a short time, while the carvings on bedrock are public and visible also for future generations; in other words, individuality vs. collectivity. This tendency is also evident within the category of carvings on bedrock. In Early Bronze age, there are generally fewer figures on smaller panels, while in the Late Bronze Age several rock motives are mainly pecked on larger panels, often tied to lines of communication.

Why does the use of bedrock surfaces for rock carvings increase during the transition to the Late Bronze
Age? Why does the central (region B, see Fig. 3) and to a certain extent the southern (region $\mathrm{C}$ ) part of Jæren lose its position? Why did the Stavanger area (region A) turn out to be the central area for religious practice? What local conditions may have accelerated this development?

In the Early Bronze Age, society was stratified, and the central part of Jæren is characterized by large ancient monuments and several bronze artifacts. In fact, several of all bronzes from Western Norway originate from the Klepp municipality. The wealth must have been built up through economic surplus, contacts and exchange of goods, where the main trade link extended to Jutland. At the beginning of the Late Bronze Age, the connection became more or less broken due to recession in this area. The consequence seems to have been that central Jæren (region B) loses its economic and social position. Furthermore, the rapid forest clearance in this area (unlike areas further north) may have resulted in less fertile soils in the following periods. Intensive land use may have led to further depletion of the soil as well as sand drift along the coast.

Everywhere in southern Scandinavia there is an ideological change. The time of building large mounds is over and there is a development towards a more egalitarian society; older mounds are now used for burials that generally contain fewer artifacts. Often rites and myths of the Bronze Age religion have been linked to sun worship and the myth of the sun's journey. The Bronze Age's religion appears to be the same throughout the entire period, but with a democratization in the Late Bronze Age, where a larger number of people now seem to participate in religious practice.

At the transition to the Late Bronze Age, economic, social and ideological changes may have led to stress. In addition, other non-anthropogenic factors may have played a role. It is plausible to include the volcanic eruption of Hekla III. Although the consequences of this eruption in our study area are unclear, the occurrence of ash clouds may have caused anxiety and fear. This may have led to increased sun worship, where collectivity becomes more important than individuality. Carving activity changes, larger groups of panels are used and an increased number of motives can be seen. The increased religious activity can thus be explained by both a change in man-made and natural conditions occurring simultaneously at the transition between the Early and the Late Bronze Age. 


\section{Litteratur}

1.ste Mai (1948, 3 Desember). Interessant helleristningsfunn på Dysjaland i Håland. Det første i sitt slag i Norge. 1.ste Mai 3/12 1948.

Aftenposten (1948, 3 Desember). Enestående helleristningsfunn. En gjeterscene fra 800 f.Kr. som like gjerne kunne være fra i dag. Aftenposten 3/12 1948.

Aftenposten (1998, 22 August). 60 år gamle guttestreker ble fredet. Intervju med Bitten Bakke og Gitte Kjeldsen vedr. skålgropsteinen på Årstad, gnr. 13, bnr. 148 mfl., Eigersund k. Aftenposten 22/08 1998.

Andersen, A. B. (1936). Utgravningsrapport. Topografisk arkiv, Arkeologisk museum/Universitetet i Stavanger.

Andersen, B. G., Wangen, O. P. \& Østmo, S. R. (1987). Quaternary geology of Jeren and adjacent areas, southwestern Norway. Norsk Geologisk Undersøkelse, Bulletin 411.

Austvoll, K. I. (2014). Constructing identities. Structure and practice in the Early Bronze Age - Southwest Norway. (Masteroppgave). IAKH, Universitetet i Oslo.

Austvoll, K. I. (2018). Seaways to Complexity. A Study of Sociopolitical Organisation Along the Coast of Northwestern Scandinavian in the Late Neolithic and Early Bronze Age. (PhD-thesis). IAKH, Universitetet i Oslo.

Bakke, B., Auestad, J., Bakkevig, S., Borgarp, C., BangAndersen, S., Høgestøl, M., Kjeldsen, G. \& Walderhaug, O. (2000). Bergkunst i Rogaland. I Hygen, A.S. (red.) Fire år med bergkunstprosjektet 1996-1999. Riksantikvarens Bergkunstprosjekt. Sikring av Bergkunst 1996-2005. Riksantikvarens rapporter 29 - 2000, 107-131.

Bakke, B. (2009a). Skadekartlegging av bergkunstlokaliteter på «Kråkhaug I» Hedland, gnr. 24, bnr. 3, "Ølbør III» Ølberg gnr. 20, bnr. 12,73, «Kvernavika» Vigdel gnr. 22, bnr. 3, «Valhaug I og II» Dysjaland gnr. 27, bnr. 1, «Valhaug III» Dysjaland gnr. 27, bnr. 11, Hellestø gnr. 23, bnr. 6, Sola kommune. Topografisk arkiv, Arkeologisk museum/ Universitetet i Stavanger.

Bakke, B. (2009b). Skadekartlegging av lokaliteter på Husabø, Haneberg og Bø. Avtegninger på kalkeringer. Topografisk arkiv, Arkeologisk museum/Universitetet i Stavanger.

Bakkevig, S. (1998a). Skjøtselsplan Ølberg, gnr. 20, Sola k. 29.09.98. Topografisk arkiv, Arkeologisk museum/ Universitetet i Stavanger.

Bakkevig, S. (1998b). Skjøtselsplan Hedland, gnr. 24, bnr. 3, Sola k. 29.09.98. Topografisk arkiv, Arkeologisk museum/ Universitetet i Stavanger.

Bakkevig, S. (2000). Skjøtselsplan Vigdel, gnr. 22, bnr. 3, Sola $k$. Topografisk arkiv, Arkeologisk museum/Universitetet i Stavanger.

Bang-Andersen, S. (1978). Notat vedr. befaring av skålgroplokalitet 25-30 m SSV for Husabø skole i Eigersund. 06.04.1978. Topografisk arkiv, Arkeologisk museum/Universitetet i Stavanger.
Bang-Andersen, S. (1982a). Rott gnr. 12, bnr. 1, 2, 23, Sola k. Registreringsrapport, Økonomisk kartverk 3075 F2 R5. 25.05.1982. Topografisk arkiv, Arkeologisk museum/ Universitetet i Stavanger.

Bang-Andersen, S. (1982b). Notat om opprydding på helleristningsfeltet 3305-L8-R1 på "Katthammer", Kirkebø, gnr. 56, bnr. 28, Sokndal k. Topografisk arkiv, Arkeologisk museum/Universitetet i Stavanger.

Bang-Andersen, S. (1985). De mange sjøers land - et bidrag til Jærens landskapshistorie. Stavanger museum årbok 1985, 55-68.

Bang-Andersen, S. (1995). Rapport om fotografering av bergkunst $i$ deler av Rogaland fylke sommeren 1995. 27.12.1995. Topografisk arkiv, Arkeologisk museum/ Universitetet i Stavanger.

Bang-Andersen, S. (1999). The rock art of Rogaland, SWNorway. Composition, consideration, conservation. Proceedings. NEWS 95 - International rock art congress, 1-10. Pinerolo, Italy.

Bang-Andersen, S. \& Thomsen, H. (1993). SPOR etter mennesker og natur på Hå i steinalderen. Hå kommune i samarbeid med Arkeologisk museum i Stavanger. Partner Print as, Stavanger.

Bergstrøm, B., Olsen, L., Riiber, K. \& Reite, A. J. (2010). ROGALAND FYLKE, løsmassekart M 1:200 000. Norges Geologiske Undersøkelse, Trondheim.

Bertelsen, R. (1970). Steinhaug på Særheim. Redegjørelse for to somres arbeid og videre planer. Frá haug ok heiðni 3, $68-71$.

Bird, E. C. F. \& Klemsdal, T. (1986). Shore displacement and the origin of the lagoon at Brusand, southwestern Norway. Norsk Geografisk Tidsskrift 40, 27-35.

Birkeland, T. (1981). The geology of Jæren and adjacent districts. A contribution to the Caledonian nappe tectonics of Rogaland, southwest Norway. Norsk Geologisk Tidsskrift 61, 213-235.

Borgarp, C. (2006). Fjerning av hæerverk på helleristningsfelt, Bø, Sokndal kommune. Topografisk arkiv, Arkeologisk museum/Universitetet i Stavanger.

Brøgger, A. W. (1910a). Helleristning på Ølbør, Sola sogn, Haaland pgd. Intern rapport og kalkering. Topografisk arkiv, Arkeologisk museum/Universitetet i Stavanger.

Brøgger, A. W. (1910b). Helleristninger ved Eigersunds prestegaard. Topografisk arkiv, Arkeologisk museum/ Universitetet i Stavanger.

Buckland, P. C., Dugmore, A. J. \& Edwards, K. J. (1997). Bronze Age myths? Volcanic activity and human response in the Mediterranean and North Atlantic regions. Antiquity 71, 581-593.

Bødal, S. (1998). Bjelland, gnr. 107, bnr. 3, 4, Sokndal k. Registrering av helleristningsfelt, skålgroper. Topografisk arkiv, Arkeologisk museum/Universitetet i Stavanger.

Coles, J. (2005). Shadows of a northern past. Rock carvings of 
Bohuslän and Østfold. Oxbow Books. Oxford.

Dahl, B. (2003). De mytiske landskap - De rituelle landskap. Et eksempel fra Rossland i Sokndal kommune, Rogaland. (Hovedfagsoppgave). Institutt for arkeologi og kulturhistorie, NTNU Universitets museet, Trondheim.

Dalane Tidende (1998, 28 August). Helleristningene er ikke guttestreker. Intervju med Bitten Bakke og Gitte Kjeldsen vedr. skålgropsteinen på Årstad, gnr. 13, bnr. 148 mfl., Eigersund k. Dalane Tidende 28/08 1998.

Egenæs Lund, H. (1934) (1932-1933). Graver og gravskikk i en bronsealders haug på Jæren. Stavanger Museums Årshefte, 43, 57-69, Stavanger.

Egenæs Lund, H. (1939). Helleristning av jordbrukstypen på Helleland i Sola s., Håland pgd. Topografisk arkiv, Arkeologisk museum/Universitetet i Stavanger.

Eide, E. (1993). Helleristningsrapporter 1993. Topografisk arkiv, Arkeologisk museum/Universitetet i Stavanger.

Espedal, O. (1969). Bø gnr. 56, bnr. 28, Sokndal k. Registrering for det økonomiske kartblad 3305 L8 R1. Topografisk arkiv, Arkeologisk museum/Universitetet i Stavanger.

Espedal, O. (1970). Regeland øvre, gnr. 70, bnr. 1, Sokndalk. Registrering for det økonomiske kartblad 3305 K8 R 22. Topografisk arkiv, Arkeologisk museum/Universitetet i Stavanger.

Espedal, O. (1972). Brev til Eigersund kommune vedr. nyoppdaget felt med offergroper, 24.5.1972. Topografisk arkiv, Arkeologisk museum/Universitetet i Stavanger.

Fett, E. \& Fett, P. (1941). Sydvestnorske helleristninger. Rogaland og Lista. Stavanger: Stavanger Museum, Dreyer forlag.

Fægri, K. (1936). Quartärgeologische Untersuchungen im westlischen Norwegen. I. Ûber zwei präboreale Klimaschwankungen im südwestlichten Teil. Bergens Museums Årbok, Naturvitenskapelig rekke 8, 1935, (2), $1-40$.

Fægri, K. (1940). Quartärgeologische Untersuchungen im westlichen Norwegen. II. Zur spätquartären Geschichte Jærens. Bergen Museums Årbok, Naturvitenskapelig Serie 8, $1939-40,1-201$.

Gansum, T., Jerpåsen, G. B. \& Keller, C. (1997). Arkeologisk landskapsanalyse. Med visuelle metoder. AmS-Varia 28, Stavanger.

Garnes, K. (1976). Stratigrafi og morfogenese av drumliner på Eigerøya, Rogaland, SV-Norge. AmS-Skrifter 1, Stavanger.

Gausland, T. (1969a). Rossland, gnr. 68, bnr. 5, Sokndal k. Registrering for det økonomiske kartblad 3305 K8 R3. Topografisk arkiv, Arkeologisk museum/Universitetet i Stavanger.

Gausland, T. (1969b). Rossland, gnr. 68, bnr. 5, Sokndal k. Registrering for det økonomiske kartblad 3305 K8 R23. Topografisk arkiv, Arkeologisk museum/Universitetet i Stavanger.

Gausland, T. (1969c). «Skolehaugen», Hauge, gnr. 55, bnr. 16, Sokndal k. Registrering for det økonomiske kartblad 3305 L8 R8. Topografisk arkiv, Arkeologisk museum/ Universitetet i Stavanger.

Gausland, T. (1969d). Skarås, gnr. 77, bnr. 8, Sokndal k. Registrering for det økonomiske kartblad 3305 L6 X3. Topografisk arkiv, Arkeologisk museum/Universitetet i Stavanger.

Gil, T. 2017. Sikringsundersøkelse av Steinhaug på Scrheim, gnr. 16, bnr. 1, Klepp k., Rogaland. Oppdragsrapport 2017/13.
Gjerde, J. M. (2002). Lokalisering av helleristninger i landskapet. I Goldhahn, J. (red.) Bilder av bronsålder - ett seminarium om förhistorisk kommunikation, (s. 23-51). Almquist \& Wiksell International, Stockholm.

Gjerde, J. M. (2015). A Stone Age rock art map at Nämforsen, Northern Sweden. Adoranten 2015, 74-91

Gjessing, H. (1920). Rogalands stenalder. Stavanger Museum Skrifter 2, Stavanger.

Goldhahn, J. (2002). Hällarnas dån - ett audiovisuellt perspektiv på kustbunden hällkonst i norra Sverige. I Goldhahn, J. (red.) Bilder av bronsålder - ett seminarium om förhistorisk kommunikation, (s. 52-90). Almquist \& Wiksell International, Stockholm.

Grimnes, A. (1910). Kart over Jæderen med Angivelse av Høideforholdene og Jordbundens Art. Norges Geologiske Undersøkelse 52a, 1889-1909. Kristiania.

Hatleskog, A. B. (1994). Statusrapport for bergkunst $i$ forbindelse med innstilling om konservering/bevaring av bergkunst $i$ Norge. Haneberg gnr. 46, Sokndal k. Topografisk arkiv, Arkeologisk museum/Universitetet i Stavanger.

Helliesen, T. (1901). Fortegnelse over oldsager indkomne til Stavanger museum i 1901. Stavanger Museums Aarshefte 1901, 89-102.

Helliesen, T. (1902). Oldtidslevninger i Stavanger Amt. Stavanger Museum Årshefte, Stavanger.

Helskog, K. (1999). The shore connection. Cognitive landscape and communication with rock carvings in Northernmost Europe. Norwegian Archaeological Review 32 (2), 73-94.

Hemdorff, O. (1985). Innberetning om befaring. Håland skole, Håland, Sola k. Topografisk arkiv, Arkeologisk museum/ Universitetet i Stavanger.

Hernæs, P. (1992a). Nytt funn av helleristninger på Ølbør i Sola. Frá haug ok heiðni 4, 7-8.

Hernæs, P. (1992b). Bare noen småstein - men likevel... Frá haug ok heiðni 4, 16.

Hernæs, P. (1992c). Oppmaling, Hellestø, gnr. 23, bnr. 3, Sola k. 23.06.1992. Topografisk arkiv, Arkeologisk museum/ Universitetet i Stavanger.

Hernæs, P. (1992d). Oppmaling, Hedland gnr. 24, bnr. 3, Sola k. 16.11.1992. Topografisk arkiv, Arkeologisk museum/ Universitetet i Stavanger.

Hernæs, P. (1992e). Maling av helleristninger på Kirkebø av Bø, gnr. 56, Sokndal k. Topografisk arkiv, Arkeologisk museum/Universitetet i Stavanger.

Hjelle, K. L., Halvorsen, L. S., Prøsch-Danielsen, L., Sugita, S., Paus, Aa., Kaland, P. E., Mehl, I. K., Overland, A., Danielsen, R., Høeg, H. I., \& Midtbø, I. (2018). Long-term changes in regional vegetation cover along the west coast of southern Norway: The importance of human impact. Journal of Vegetation Science (IAVS) 2018, 1-12. + 6 supplements.

Holmsen, G. (1922). Torvmyrenes lagdeling i det sydlige Norges lavland. Norges Geologiske Undersøkelse 90, Trondheim.

Høeg, H. I. (1999). Pollenanalytiske undersøkelser i Rogaland og Ersdal i Vest-Agder. I Selsing, L. \& Lillehammer, G. (red.). Museumslandskap. Artikkelsamling til Kerstin Griffin på 60-årsdagen. (s.145-226). AmS-Rapport 12A, Stavanger.

Høgestøl, M. (2017). I mørket - i lyset - skjult. Om en nyoppdaget bergkunstlokalitet i Haugesund. Frá haug ok heiðni 2, 3-7.

Høgestøl, M., Bakke, B., Bakkevig, S., Bjelland, T., Borgarp, C., 
Kjeldsen, G. \& Walderhaug. O. (1999). Helleristningsfeltene på Austre Åmøy, Stavanger kommune, Rogaland.

Dokumentasjon, sikring og tilrettelegging av feltene I til VI5. AmS-Rapport 9, Stavanger.

Høgestøl, M. \& Prøsch-Danielsen, L. (2006). Impulses of agro-pastoralism in the 4th and 3rd millennia BC on the south-western coastal rim of Norway. Environmental Archaeology 11, 19-34.

Høgestøl, M., Prøsch-Danielsen, L., Bakke, B., Bakkevig, S., Borgarp, C., Kjeldsen, G., Meeks, A., Nitter, M. \& Walderhaug, O. (2006). Helleristningslokaliteter $i$ stavangerområdet, Rogaland. AmS-Rapport 19, Stavanger.

Haaland, P. T. (1967a). Husabø, gnr. 12, bnr. 26, Eigersund k. Registrering for det økonomiske kartblad 1891 H8 R3. Topografisk arkiv, Arkeologisk museum/Universitetet i Stavanger.

Haaland, P. T. (1967b). ØK-registrering av en skålgroplokalitet på Årstad, nr. 13, bnr. 148 mfl., Eigersund k. Registrering for det økonomiske kartblad. Topografisk arkiv, Arkeologisk museum/Universitetet i Stavanger.

Haaland, P. T. \& Berge, M. (1968). ØK-registrering av bergkunstlokalitet på Dysjaland, gnr. 27, bnr. 11, Registrering for det økonomiske kartblad, Sola k., 17.08.1968. Topografisk arkiv, Arkeologisk museum/ Universitetet i Stavanger.

Haavaldsen, P. (1991). ØK-registrering av bergkunstlokalitet på Tjora, gnr. 10, Sola k. Registrering for det økonomiske kartblad, 24.10.1991. Topografisk arkiv, Arkeologisk museum/Universitetet i Stavanger.

Iversen, F. (2016). Estate division: Social cohesion in the aftermath of AD 536-7. I Iversen, F. \& Petersson, H. (red.) The agrarian life of the north 2000 BC-AD 1000. Studies in rural settlement and farming in Norway (s. 41-75). Portal Academic, Kristiansand.

Johansen, Ø. (1981). Metallfunnene i østnorsk bronsealder. Kulturtilknytning og forutsetninger for en marginalekspansjon. Universitetets oldsaksamling Skrifter. Ny Rekke 4.

Johnsen, J. (1968a). Ristninger på berg og heller i StavangerSola-området. Frá haug ok heiðni 3, 149-76.

Johnsen, J. (1968b). Teikning av bergkunstmotivene på «Kråkhaug», Helland, gnr. 24, bnr. 3, Sola k. Topografisk arkiv, Arkeologisk museum/Universitetet i Stavanger.

Johnsen, J. (1971a). Dysjaland, gnr. 27, bnr. 1, Sola. "Valhaug". Ristningsforekomst 51, felt I. Topografisk arkiv, Arkeologisk museum/Universitetet i Stavanger.

Johnsen, J. (1971b). Dysjaland, gnr. 27, bnr. 1, Sola. "Valhaug". Ristningsforekomst 51, felt II. Topografisk arkiv, Arkeologisk museum/Universitetet i Stavanger.

Johnsen, J. (1971c). Dysjaland, gnr. 27, bnr. 11, Sola. Ristningsforekomst 51, felt III. Topografisk arkiv, Arkeologisk museum/Universitetet i Stavanger.

Johnsen, J. (1974). Rogalandsristningane - typologiske freistnader. (Avhandling til Magistergraden). Universitetet i Bergen, Bergen.

Jorde, K., Sigmond, E. M. O. \& Thorsnes, T. (1995). Stavanger. Berggrunnsgeologisk kart 1:250 000. Norges Geologiske Undersøkelse, Trondheim.

Kaul, F. (1998). Ships on Bronzes. A study in Bronze Age Religion and Iconography. PNM, Publications from the National Museum Studies in Archaeology \& History Vol, 3, 1, Copenhagen.

Kaul, F. (2004). Bronzealderens religion. Studier af den nordiske bronzealders ikonografi. Det kongelige nordiske oldtidsselskab, København.

Kjeldsen, G. (2002). Å forstå helleristninger. Frá haug ok heiðni 1, 13-17.

Kjeldsen, G. (2005). Bronsealderens bergkunst på Austre Åmøy i Rogaland. K.A.N. Kvinner i arkeologi i Norge 25, 29-39.

Kjeldsen, G. (2017). Deep Time Rock Art in SW-Norway. Adoranten 2017, Scandinavian Society for Prehistoric Art, Tanums Hälleristningsmuseum Underslös, 96-101.

Knudsen, C. G. (2006). Glacier dynamics and Late glacial environmental changes - evidences from $S W$ Norway and Iceland. (PhD-thesis), Universitetet i Bergen, Bergen.

Knudsen, C. G., Sejrup, H. P. \& Larsen, E. (2006). Timing of the last deglaciation in SW Norway - evidences from lake sediments. Paper II. I Knudsen, C. G. 2006. Glacier dynamics and Late glacial environmental changes evidences from SW Norway and Iceland. (PhD-thesis), Universitetet i Bergen, Bergen.

Kvalø, F. (2007). Oversjøiske reiser fra Sørvest-Norge til Nordvest-Jylland i eldre bronsealder - en drøfting av maritim realisering og rituell mobilisering. I Hedeager, L. (red.), Sjøreiser og stedsidentitet. Jceren/Lista i bronsealder og eldre jernalder (s. 11-134). Oslo Arkeologiske Serie, 8. Oslo.

de Lange, E. (1913). Ornerte heller i norske bronsealdergraver. Bergen Museums Årbok 1912, (4), 3-36.

Ling, J. (2013). Rock Art and Seascapes in Uppland. Oxbow Books, Oxford.

Ling, J. (2014). Elevated rock art. Towards a maritime understanding of rock art in northern Bohuslän, Sweden. Swedish Rock Art Series 2, Oxbow Books.

Ljungquist, C. F. (2009). Global nedkylning. Klimatet och människan under 10000 år. Norsteds Akademiska Förlag, Stockholm.

Lødøen. T. K. (2015). Contextualizing cup marks: An approach for a better dating and understanding of their meaning and function. I Indrelid, S., Hjelle, K. L. \& Stene, K. (red.) Exploitation of outfield resources - Joint Research at the University Museums of Norway (s. 223-230) Universitetsmuseet i Bergen skrifter nr. 32.

Maijer, C., Hermans, G. A. E. M., Tobi, A. C. \& Jansen, J. B. H. (1987). Day 10-Caledonides and westernmost Precambrian intrusions. I Maijer, C. \& Padget, P. (red.) The geology of southernmost Norway. An excursion guide. (s. 99-104). Geological Survey of Norway, Special Publication 1, Trondheim.

Mandt, G. (1972). Bergbilder i Hordaland: En undersøkelse av bildenes sammensetning, deres naturmiljø og kulturmiljø. Årbok for Universitetet i Bergen, Humanistisk Serie 1979 (29). Bergen.

Mandt, G. (1991). Vestnorske ristninger i tid og rom. Kronologiske, korologiske og kontekstuelle studier. Bind 2. (Doktorgradsavhandling), Universitetet i Bergen, Bergen.

Mandt, G. \& Lødøen, T. (2004). Bergkunst. Helleristningar $i$ Noreg. Det Norske Samlaget. Oslo.

Marker, M., Schiellerup, H., Meyer, G., Robins, B. \& Bolle, O. (2003). Rogaland Anorthosite Province- Syntheses. An introduction to the geological map of the Rogaland Anorthosite Province 1:75,000. I Roberts, D. (red.) Ilmenite deposits and their geological environment (s. 109116). Geological Survey of Norway, Special Publication 9, Trondheim. 
Marstrander, S. (1963). Østfolds jordbruksristninger, Skjeberg I - II. Universitetsforlaget, Oslo.

Mauritzen, M. (1974). Rapport fra undersøkelse av impregnering av to flyttblokker på Scerheim. Topografisk arkiv, Arkeologisk museum/Universitetet i Stavanger.

Moen, A. (1999). National Atlas of Norway. Vegetation. Norwegian Mapping Authority, Hønefoss.

Myhre, B. (1964). Et nytt helleristningsfelt på Helleland i Sola. Stavanger Museum Årbok 1963, 3-14, Stavanger.

Myhre, B. (1981). Sola og Madla i førhistorisk tid. AmSSmåtrykk 10, Stavanger.

Myhre, B. (2013). Jæren og Jylland. Like kulturområder i bronsealderen. I Bøe, J.B. \& Smith-Solbakken, M. (red.) Frå eldste tider til 1000-talet. Hå kulturhistorie, band 1. (s. 219-236), Akademika forlag, Trondheim.

Myhre, L. N. (2004). Trialectic Archeology. Monuments and space in Southwest Norway 1700-500 BC. AmS-Skrifter 18 , Stavanger.

Møllerop, O. (1949a). Innberetning om reise til Dysjaland $i$ Håland 8. okt. 1948. Topografisk arkiv, Arkeologisk museum/Universitetet i Stavanger.

Møllerop, O. (1949b). Helleristningene på Dysjaland. Stavanger Museum Årbok 1948, 37-39, Stavanger.

Møllerop, O. (1958a). Innberetning til Top.ark. Drange, gnr. 8, Helleland. Topografisk arkiv, Arkeologisk museum/ Universitetet i Stavanger.

Møllerop, O. (1958b). Befaring til Rossland, Sokndal 21/5-58. Topografisk arkiv, Arkeologisk museum/Universitetet i Stavanger.

Møllerop, O. (1989). Fra forhistorien i Klepp. Frá haug ok heiðni 2, 200-212.

Norges Geologiske Undersøkelse (2009). Berggrunn Nasjonal berggrunnsdatabase, http://www.ngu.no/kart/ bg250/MapFrame.htm (sist tilgjengelig 17.05.2017)

Norland, J. (1969). Haneberg, gnr. 46, bnr. 2, Sokndal k. 3305 L8 R9. Registreringsrapport for Økonomisk kartverk. Topografisk arkiv, Arkeologisk museum, Universitetet i Stavanger.

Oma, K. A. (2018). The sheep people. The ontology of making lives, building homes and forging herds in Early Bronze Age Norway. Sheffield: Equinox Publishing, Sheffield.

Petersen, J. (1923a). Indberetning om reise til Sogndal i Dalene 3-4/4 1923, 18.08.1923. Topografisk arkiv, Arkeologisk museum/Universitetet i Stavanger.

Petersen, J. (1923b). Reiser i Sogndal 14-20/7 1923, 18.08.1923. Topografisk arkiv, Arkeologisk museum/Universitetet i Stavanger.

Petersen, J. (1939). Diverse steder i Sokndal, 19.07.1939. Topografisk arkiv, Arkeologisk museum/Universitetet i Stavanger.

Petersen, J. (1952). Avskrift av "Aktuelt" sendt i NRK: "Hovet" på Haneberg i Sokndal. Topografisk arkiv, Arkeologisk museum/Universitetet i Stavanger.

Plunkett, G. (2006). Hekla 3, environmental downturn and Irish Late Bronze Age hillfort connections revisited. Emania 20, 55-60.

Provan, D. (1974). Impregnering av flyttblokker og jordsmonn. Topografisk arkiv, Arkeologisk museum/Universitetet i Stavanger.

Prøsch-Danielsen, L. (1993). Naturhistoriske undersøkelser $i$ Rennesøy og Finnøy kommuner, Rogaland, Sørvest-Norge. AmS-Varia 22, Stavanger.
Prøsch-Danielsen, L. (2002). Jordbruksristningene i ulike landskapsrom. Frá haug ok heiðni 1, 5-12, Stavanger.

Prøsch-Danielsen, L. (2006). Sea-level studies along the coast of southwestern Norway. With emphasis on three shortlived Holocene marine events. AmS-Skrifter 20, Stavanger.

Prøsch-Danielsen, L. (2013). Tre landskap forma av isen. I Bøe, J.B. \& Smith-Solbakken, M. (red.) Frå eldste tider til 1000-talet. Hå kulturhistorie, band 1. (s. 71-81), Akademika forlag, Trondheim.

Prøsch-Danielsen, L., Prescott, C. \& Kähler Holst, M. (2018). Economic and social zones during the Late Neolithic/Early Bronze Age in Jæren, Southwest Norway. Reconstructing large-scale land-use patterns. Prähistorische Zeitschrift 93(1), 48-88.

Prøsch-Danielsen, L. \& Selsing, L. (2009). Aeolian activity during the last 9200 calendar years BP along the southwestern coastal rim of Norway. AmS-Skrifter 21, Stavanger.

Prøsch-Danielsen, L. \& Sandgren, P. (2003). The use of pollen, magnetic and carbon analyses in identifying agricultural activity and soil erosion from the Neolithic to the Iron Age - A study of two lake sediment cores from Jæren, South-Western Norway. Environmental Archaeology 8, 33-50.

Prøsch-Danielsen, L. \& Simonsen, A. (2000a). The deforestation patterns and the establishment of the coastal heathland of southwestern Norway. AmS-Skrifter 15, Stavanger.

Prøsch-Danielsen, L. \& Simonsen, A. (2000b). Palaeoecological investigations towards the reconstruction of the history of forest clearances and coastal heathlands in south-western Norway. Vegetation History and Archaeobotany 9, 189-204.

Ramstad, M. (2000). Veideristningene på Møre. Teori, kronologi og dateringsmetoder. Viking 63, 51-89.

Rogaland (1948, 3 Desember). Jordbruks-risting frå bronsealderen i Sola. Forvitneleg funn på garden til Ommund Dysjaland. Rogaland 3/12 1948.

Romundset, A., Fredin, O. \& Høgaas, F. (2015). A Holocene sea-level curve and revised isobase map based on isolation basins from near the southern tip of Norway. Boreas 2015. 44 (2), 383-400. DOI 10.111/bor. 12105.

Sejrup, H. P., Iversen, M., Larsen, E., Landvik, J. Y. \& Janocko, J. (1999). A stage 7 marine interglacial record (the Grødaland Interglacial) on Jæren, southwestern Norway; foraminiferal, stable isotopes and amino acid evidence. Boreas 28, 326-346.

Sejrup, H. P., Landvik, J. Y., Larsen, E., Janocko, J., Eiriksson, J. \& King, E. (1998). The Jæren area, a border zone of the Norwegian Channel Ice stream. Quaternary Science Reviews 17, 801-812.

Simonsen, A. (2005). Submerged lacustrine sediments and sea level fluctuations at Eigerøy, SW-Norway. Topografisk arkiv, Arkeologisk museum/Universitetet i Stavanger.

Skjølsvold, A. (1961). Tradisjon om en gammel helligåker? Frá haug ok heiðni 1, 41-44, Stavanger.

Skjølsvold, A. (udatert). Bilder fra Hanaberg i Sokndal. Note. Topografisk arkiv, Arkeologisk museum/Universitetet i Stavanger.

Sognnes, K. (1984). Kulturlandskap, bergkunst og bosetning i Stjørdal i bronsealderen. Viking XLVII, 136-148. Oslo.

Sognnes, K. (1987). Rock art and settlement pattern in the 
Bronze Age. Examples from Stjørdal, Trøndelag, Norway Norwegian Archaeological Review 20 (2), 110-119.

Sognnes, K. (2001). Prehistoric imaginery and landscapes. Rock art in Stjørdal, Trøndelag, Norway. BAR International Series 998. Oxford.

Stalsberg, K., Landvik, J. Y., Larsen, E. \& Sejrup, H. P. (1999). Saalian to Weichselian stratigraphy and sedimentation along the Lågjæren-Høgjæren escarpment, southwest Norway. Journal of Quaternary Science 14, 299-312.

Stavanger Aftenblad (1948, 3 Desember). Helleristninger $i$ Håland. Interessant gruppe funnet på Dysjaland. Stavanger Aftenblad 3/12 1948.

Stommel, H. \& Stommel, E. (1979). The year without summer. Scientific American 240 (6), 176-186.

Syvertsen, K. I. J. (2002). Ristninger i graver - graver med ristninger. I Goldhahn, J. (red.) Bilder av bronsålder - ett seminarium om förhistorisk kommunikation, (s. 151-184). Almquist \& Wiksell International, Stockholm.

Syvertsen, K. I. J. (2003). Ristninger i graver-graver med ristninger. Om ristningers mening i gravminner og gravritualer. En analyse av materiale fra Rogaland. (Hovedfagsoppgave), Universitetet i Bergen, Bergen.

Sømme Dahl, J. M. (1976). Kontroll første uke av juli 1976. Topografisk arkiv, Arkeologisk museum/Universitetet i Stavanger.

Sømme Dahl, J. M. (1979). Kontroll av forsøksfelt på Sarheim. Topografisk arkiv, Arkeologisk museum/Universitetet i Stavanger.

Sømme Dahl, J. M. (1985). Helleristningsfelt i Sola kommune, forvitringsgeologisk undersøkelse. Topografisk arkiv, Arkeologisk museum/Universitetet i Stavanger.

Sør-Reime, G. (1984a). Rapport fra helleristningsgruppa 1984:3. Befaring 12.6.1984 til ristningsfelt i Sola. Topografisk arkiv, Arkeologisk museum/Universitetet i Stavanger.

Sør-Reime, G. (1984b). Innberetning til topografisk arkiv om synfaring vedkj. skader på helleristningsfelt reg. nr. 1891 H6 R1. Topografisk arkiv, Arkeologisk museum/Universitetet i Stavanger.

Sør-Reime, G. (1985a). Årsrapport 1985 for helleristningsgruppa. Topografisk arkiv, Arkeologisk museum/Universitetet i Stavanger.

Sør-Reime, G. (1985b). Rapport fra helleristningsgruppa 1985:1. Befaring 27.3.85 til felt i Eigersund og Sokndal. Topografisk arkiv, Arkeologisk museum/Universitetet i Stavanger.

Thomsen, H. (1983). Sele-rapporten. Resultatene fra den naturvitenskapelige forundersøkelsen fra Sele-Bybergområdet. Topografisk arkiv, Arkeologisk museum/ Universitetet i Stavanger.

Trøim, I. \& Henriksen, R. (1991a). Ølberg, gnr. 20, bnr. 1, 17, Sola k. Registrering for det økonomiske kartblad 9360 D2
R7. Topografisk arkiv, Arkeologisk museum/Universitetet i Stavanger.

Trøim, I. \& Henriksen, R. (1991b). Hellestø gnr. 23, bnr. 6, Sola k. Registrering for det økonomiske kartblad 3075 J2 R22. Topografisk arkiv, Arkeologisk museum/Universitetet i Stavanger.

Trøim, I. \& Henriksen, R. (1991c). Håland gnr. 21, bnr. 1, 2, Sola k. Registrering for det økonomiske kartblad 9964 A8 R9, 30/4 1991. Topografisk arkiv, Arkeologisk museum/ Universitetet i Stavanger.

Trøim, I. \& Henriksen, R. (1991d). Håland gnr. 21, bnr. 1, 2, Sola k. Registrering for det økonomiske kartblad 9964A8 R5, 29/4 1991. Topografisk arkiv, Arkeologisk museum/ Universitetet i Stavanger.

Trøim, I. \& Henriksen, R. (1991e). Tjelta gnr. 28, bnr. 18, Sola k. Registrering for det økonomiske kartblad 9964 A7 R50. Topografisk arkiv, Arkeologisk museum/Universitetet i Stavanger.

Trøim, I. \& Henriksen, R. (1991f). Tjelta gnr. 28, bnr. 28, Sola k. Registrering for det økonomiske kartblad 9964 A7 R42, 2/5 1991. Topografisk arkiv, Arkeologisk museum/ Universitetet i Stavanger.

Tybring, F. (1904). Helleristninger ved Eigersunds prestegaard. Stavanger Museums Aarshefte 1904, 31-32, Stavanger.

Vevatne, K. (1996). Ristningar i Etne - ein analyse av tid og rom. (Hovedfagsoppgave), Arkeologisk institutt, Universitetet i Bergen, Bergen.

Vevatne, K. (2002). «Smålåtne» vestnorske ristningar? Frá haug ok heiðni 1, 18-21.

Vinsrygg, S. (1982a). Befaring til Hellestø, Sola (gnr. 23, fellesmark). Note 01.07.1982. Topografisk arkiv, Arkeologisk museum/Universitetet i Stavanger.

Vinsrygg, S. (1982b). Befaring til Helleland Sola. Note 01.07.1982. Topografisk arkiv, Arkeologisk museum/ Universitetet i Stavanger.

Vogt, D. (2012). Østfolds helleristninger, Universitetsforlaget, Oslo.

Wangen, O. P., Østmo, S. R. \& Andersen, B. G. (1987). The Jaren map area, Quaternary deposits - Scale 1:100 000. Geological Survey of Norway, Trondheim.

Wishaupt, J. \& van Wees, B. (1985). On the geology of a Caledonian polymetamorphic nappe complex in the Jaren district, Rogaland, SW Norway. (Internal report). Institute for petrology, University of Utrecht, the Netherlands.

Wrigglesworth, M. (2002). Ristninger og graver i landskapet. I Goldhahn, J. (red.) Bilder av bronsålder - ett seminarium om förhistorisk kommunikation, (s. 185-199). Almquist \& Wiksell International, Stockholm.

Wrigglesworth, M. (2011). Finding your place: Rock art and local identity in West Norway. A study of Bronze Age rock art in Hardanger and Sunnhordland. (PhD- thesis), University of Bergen, Bergen. 


\section{AmS-Varia}

